$$
\text { DR. } 660
$$

MASTER

SAN-1743-3

ENGINEERING AND ECONOMIC ANALYSIS FOR THE UTILIZATION OF GEOTHERMAL FLUIDS IN A CANE SUGAR PROCESSING PLANT

Final Report

By

John T. Hume

Melvin T. Tanka

Melvin H. Yokota

Augustine S. Furumoto

July 1979

Date Published

Work Performed Under Contract No. ET-78-C-03-1743

Pun Sugar Company

Amfac, Inc.

Honolulu, Hawaii

U. S. DEPARTMENT OF ENERGY Geothermal Energy

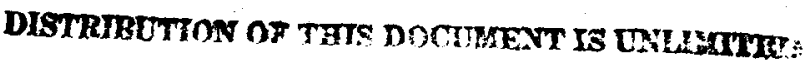




\section{DISCLAIMER}

This report was prepared as an account of work sponsored by an agency of the United States Government. Neither the United States Government nor any agency Thereof, nor any of their employees, makes any warranty, express or implied, or assumes any legal liability or responsibility for the accuracy, completeness, or usefulness of any information, apparatus, product, or process disclosed, or represents that its use would not infringe privately owned rights. Reference herein to any specific commercial product, process, or service by trade name, trademark, manufacturer, or otherwise does not necessarily constitute or imply its endorsement, recommendation, or favoring by the United States Government or any agency thereof. The views and opinions of authors expressed herein do not necessarily state or reflect those of the United States Government or any agency thereof. 


\section{DISCLAIMER}

Portions of this document may be illegible in electronic image products. Images are produced from the best available original document. 


\section{NOTICE}

This report was prepared as an account of work sponsored by the United States Government. Neither the United States nor the United States Department of Energy, nor any of their employees, nor any of their contractors, subcontractors, or their employees, makes any warranty, express or implied, or assumes any legal liability or responsibility for the accuracy, completeness or usefulness of any information, apparatus, product or process disclosed, or represents that its use would not infringe privately owned rights.

This report has been reproduced directly from the best available copy.

Available from the National Technical Information Service, U. S. Department of Commerce, Springfield, Virginia 22161.

Price: Paper Copy $\$ 11.00$

Microfiche $\$ 3.00$ 


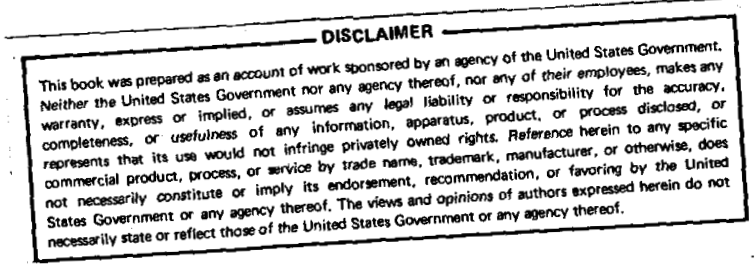

\title{
ENGINEERING AND ECONOMIC ANALYSIS FOR THE UTILIZATION OF GEOTHERMAL FLUIDS IN A CANE SUGAR PROCESSING PLANT
}

\section{FINAL REPORT}

JOHN T. HUMME

MELVIN T. TANAKA

MELVIN H. YOKOTA

AUGUSTINE S. FURUMOTO

\author{
Puna Sugar Co. - Amfac, Inc. \\ P. 0. Box 3230 \\ Honolulu, Hawait 96801 \\ Date Published - July 1979
}

\author{
Prepared for the \\ DEPARTMENT OF ENERGY \\ DIVISION OF GEOTHERMAL ENERGY \\ UNDER DOE CONTRACT ET-78-C-03-1743
}


ABSTRACT

The purpose of this study was to determine the feasibility of geothermal resource utilization at the Puna Sugar Company cane sugar processing plant, located in Keaau, Hawaii. A proposed well site area was selected based on data from surface exploratory surveys. The liquid dominated well flow enters a binary thermal arrangement, which results in an acceptable quality steam for process use. Hydrogen sulfide in the well gases is incinerated, leaving sulfur dioxide in the waste gases. The sulfur dioxide in turn is recovered and used in the cane juice processing at the sugar factory.

The clean geothermal steam from the binary system can be used directly for process requirements. It replaces steam generated by the firing of the waste fibrous product from cane sugar processing. The waste product, called bagasse, has a number of alternative uses, but an evaluation clearly indicated it should continue to be employed for steam generation. This steam, no longer required for process demands, can be directed to increased electric power generation. Revenues gained by the sale of this power to the utility, in addition to other savings developed through the utilization of geothermal energy, can offset the costs associated with hydrothermal utilization.

The recommended system is entirely feasible from a technical viewpoint. It is only marginally profitable based on private financing. However, there is some basis to anticipate partial government participation in the project. This may provide the impetus to carry the program through the implementation phase and into commercial operation. 


\section{TABLE OF CONTENTS}

Section

Title

Page

ABSTRACT

TABLE OF CONTENTS

iv

LIST OF TABLES

$x i j$

LIST OF FIGURES

xiv

DEFINITIONS

xvii

ABBREVIATIONS

$x i x$

1

INTRODUCTION

$1-1$

1.1 Authorization

$1-2$

1.2 Statement of Objectives

$1-2$

1.3 Method of Accomplishing the Study 1-4

1.4 Organization of the Report 1-4

2

SUMMARY, CONCLUSIONS AND RECOMMENDATIONS

$2-1$

2.1 Background

$2-1$

2.2 Summary

$2-2$

2.2.1 Baseline Plant Facility and

Process Description

2.2.2 Reservoir Potential

2-3

2.2.3 Design Synthesis Criteria

2-3

2.2.4 Functiona1 Design

$2-4$

2.2.5 Project Schedule

2-6

2.2.6 Risk Assessment

2-6 
2.2.8 Environmental Concerns

3.2 Corporate Structure and History 3-1

3.3 Baseline Plant Facility 3-7

3.4 Baseline Process Description 3-7

3.4.1 Cane Weighing and Sampling 3-8

3.4.2 Cane Cleaning 3-8

3.4.3 Cane Preparation 3-10

3.4.4 Cane Diffusion 3-10

3.4.5 Juice Sulfitation 3-11

3.4.6 Juice Heating 3-11

3.4.7 Juice Weighing 3-11

3.4.8 Juice Evaporation 3-11

3.4.9 Sugar Crystallization 3-11

3.4.10 Bagasse Dewatering 3-12

3.4.11 Bagasse Storage 3-12

3.4.12 Steam Generation 3-13

3.4.13 Electric Generation 3-14

3.5 Baseline Steam and Condensate Cycle 3-15 
3.6 Comparison with Beet Sugar Processing

3.6.2 Dissimilarities

3.7 Other Potential Geothermal Energy Users in the Area

3.7.1 Papaya Processing

3.7.2 Macadamia Nut Processing

3.7.3 Slaughter House Operations

4.1 Regional Geology

4.1.1 Regional Setting

4.1.2 Hawaiian Volcanic Structure

4.2 The East Rift Zone of Kilauea Volcano

4.2.1 The Exploration Program

4.2.2 Geology of the East Rift Zone

\subsubsection{The Subsurface Structure of the} East Rift Zone

4.2.4 The Thermal Process of the East Rift Zone

4.3 Comparison of the Proposed Site and the HGP-A Site 
5.1 Cane Production

5.2 Weekly Factory Schedule

5.3 Campaign Duration

5.4 Process Rate

$5-3$

5.5 Equipment

$5-3$

5.6 Resource Site and Characteristics

6.1 Recommended System

6.2 Well Site Facilities

6-4

6.2.1 Well Site

$6-6$

6.2.2 Production Wells and Characteristics

$6-13$

6.2.3 Silencer and Separator Stack

6.2.4 Separator

6.2.5 Brine Disposal

6.2.6 Evaporators

6.2.7 $\mathrm{H}_{2} \mathrm{~S}$ Conversion

6.2.8 Water Development

6.2.9 Electric Power Supply

6.2.10 0ther Well Site Facility Options Evaluated

6.3 Resource Transmission

6.3.1 Pipeline

6.3.2 Thermal Losses 
(Continued)

6.3.3. Pipeline Corridor

6-29

6.3.4 Pipeline Easements

$6-30$

6.3.5 Other Resource Transmission Options Evaluated

6.4 Factory Site Retrofit

6-33

6.4.1 Separator

$6-33$

6.4.2 Turbogenerator Modifications

$6-33$

6.4.3 Cooling Water Development and Disposal

$6-38$

6.4.4 Factory Steam Flows

$6-38$

6.4.5 Other Factory Retrofit Options Evaluated

6.5 System Manning Schedule

7.1 Feasibility Study

7.2 Corporate Functions

7.3 Wellsite Functions

7.4 Pipeline Functions

7.5 Factory Retrofit Functions

7.6 Commencement of Operation

$7-5$

8.1 Volcanism and Tectonic Movement

8.1.1 Direct Hazards

8.1.2 Indirect Hazards 


\section{TABLE OF CONTENTS}

(Continued)

Section

Title

Page

8.2 Vandalism

$8-13$

8.3 Well Blowout

8-14

8.4 Resource Supply Reliability

8-14

9

ECONOMIC ANALYSIS $\quad 9-1$

9.1 Economics of the Proposed System 9-1

9.1.1 Project and Equipment Life 9-2

9.1.2 Cost Escalation 9-4

9.1.3 System Cash Requirements 9-4

9.1.4 System Revenues 9-7

9.1.5 System Operating Costs 9-15

9.1.6 System Depreciation 9-18

9.1.7 Tax and Tax Incentives 9-20

9.1.8 Analysis with Discounted Cash

Flow Method $\quad 9-22$

$\begin{array}{ll}9.2 \text { Public Benefits } & 9-22\end{array}$

9.2.1 Geothermal Mining Leases and 9-25

Royalties

9.2.2 Operating and Maintenance 9-25

Expenditures

9.2.3 Electric Rates 9-27

$\begin{array}{ll}\text { 9.3 Alternative Methods of Financing 9-27 } & \text { 9- }\end{array}$

9.3.1 DOE Geothermal Loan Guarantee 9-28 Program

9.3.3 Tax Exempt Industrial Develop- 9-28 ment Bonds 
10.1 Project Description

10.1.1 Well Site Facilities

10-3

10.1.2 Resource Transmission

10-3

10.1.2 Factory Retrofit

$10-3$

10.2 The Natural Environment

10.2.1 Physiography

$10-4$

10.2.2 Geology and Soils

10-6

10.2.3 Hydrology

10-7

10.2.4 Meteorology

10-9

10.2.5 Chemical Toxicants in the Air, Water and Soil

10.2.6 Flora and Fauna

10.2.7 Natural Hazards

$10-20$

10.2.8 Aesthetics

$10-22$

10.3 The Socioeconomic Environment

10.3.1 Land Ownership

$10-30$

10.3.2 Land Use

$10-30$

10.3.3 Land Zoning

10-34

10.3.4 Sugar Production Areas

$10-34$

10.3.5 Infrastructure and Economic Circumstances

10.3.6 Archaeological and Historical Sites

10.3.7 Hawaiian Culture 
(Continued)

11.1 Administrative Concern

11.1.1 Geothermal Ownership Rights

11.1.2 Permitting Process

11.1.3 Pipeline Rights-of-Way

$11-10$

11.1.4 Environmental Restrictions

11-11

11.2 Tax Policy

11-12

11.3 Electric Rate Structure

11.4 Electric Power Production and Export

11.4.1 Export Power and Energy Schedule

Appendix A PUNA SUGAR COMPANY BASELINE OVERALL MATERIAL BALANCE 


\section{LIST OF TABLES}

Table

Title

Page

$3-1$

Puna Sugar Baseline Export Power and Energy Schedule

3-16

4-1 Comparison of Geophysical Parameters for Geothermal Evaluation

4-33

6-1

HGP-A Well Flow Property Data

6-14

6-2

HGP-A Geochemical Summary

6-18

6-3

Summary of Gas Analyses for HGP-A

6-22

6-4

Standards of $\mathrm{H}_{2} \mathrm{~S}$ and $\mathrm{SO}_{2}$

6-23

6-5

Manning Schedule

6-42

9-1

Project Cash Requirement Summary

9-5

9-2

Effect of Well Cost Capitalization on ROI

$9-6$

9-3

Wellsite Cash Requirements

9-8

$9-4$

Transmission Pipeline Cash Requirements

9-9

9-5

Factory Retrofit Cash Requirements

9-10

$9-6$

Anticipated Revenues

9-12

9-7

Capacity Charge Revenues

9-14

9-8

System Operating and Maintenance costs

9-16

9-9

Operating and Maintenance Cost Components

9-17

9-10

Cash Flow

9- 19

9-11

Percentage Depletion Allowance Schedule

9-23

9-12

Discounted Cash Flow and Cash Requirements

9-24

9-13

Accumulated Public Benefits from the Project

9-26 
10-1 Chemical Toxicants At The Hawaii Geothermal Project Well

Mercury Levels Outside the HGP-Puna Drill Site Area: Comparative Air and Water Data, 1971-1976

Predominant Flora Found in the Project Area

Proposed County of Hawaii Allowable Noise Levels 


\section{LIST OF FIGURES}

Figure

$\underline{\text { Title }}$

Page

3-1

Map of the Island of Hawaii (County of Hawai i)

$3-2$

3-2

Aerial View of the Puna Sugar Company Process Plant

3-5

3-3

Factory Site Plan

3-6

3-4

Baseline Process Flow Diagram

3-9

3-5

Baseline Steam and Condenstate Flow Diagram, Weekday Operation - 4

MW Export

3-6

Baseline Steam and Condensate Flow

Diagram, Weekday Operation - 6

MW Export

3-7

Baseline Steam and Condensate Flow Diagram, Weekend Operation - 4

MW Export

$3-8$

Baseline Steam and Condensate Flow Diagram, Weekend Operation - 6 MW Export

4-1 Relief Model of the Southwestern Hawaiian Ridge

$4-2$

Map of the Island of Hawai

4-4

4-3

Conceptual Diagram of Kilauea Volcano's Magmatic Process

Areas of Electrical Anomalies

Geographical Names in the Puna District

Velocity-Depth Profile of an East Rift Zone Section Traverse 

Plane

HGP-A Shut-in and Production Downhole Well Temperatures

The Downhole Distribution of $\mathrm{pH}$ for HGP-A

The Downhole Distribution of Silica for HGP-A

Self Potential Contours at Site $B$

Self Potential Contours at Site A

Volcanoes and Rift Zones of the Island of Hawai $i$

Map of Proposed Well Site

Northeast Aerial View of the Proposed Well Site

Southerly Aerial View of the Proposed Well Site 


\section{LIST OF FIGURES}

(Continued)

Figure

Title

Page

$6-10$

Proposed Steam and Condensate Flow Diagram, Weekday Operation

$6-34$

$6-11$

Proposed Steam and Condensate Flow Diagram, Weekend Operation

6-35

$6-12$

Proposed Steam and Condensate Flow Diagram, Supplemental Fuel 0il Firing

$6-36$

7-1

Project Schedule

7-2

8-1

Zones of Overall Relative Risk from Volcanic Hazards

8-2

8-2

Zones of Relative Risk from Falling Volcanic Fragments

$8-4$

8-3 Eruptive Vents in the Lower East Rift Zone

8-6

8-4

Zones of Relative Risk from Lava-flow Burial

8-7

8-5

Zones Subject to High Risk From Subsidence

8-10

8-6

General Areas of Risk From Surface Ruptures

8-12

9-1

Project Financial Flow Model

9-3

Simplified Proposal Schematic

10-2

$10-2$

Map of Puna District

10-5

$10-3$

Map of Land Ownership, Puna District

10-31

$10-4$

Map of Land Use Allocation, Puna District

10-33

$10-5$

Map of Land Zoning, Puna District

10-35

$10-6$

Map of Puna Sugar Company Cane Lands

10-37 


\section{DEFINITIONS}

BAGASSE: Fibrous residue remaining after extraction of juice from sugar cane.

BRIX: The precent by weight of solids in solution, as measured by a brix hydrometer, or other densimetric device.

BUSBAR: Net electricity generated that enters the system distribution network.

CAMPAIGN: The length of the cane processing year. Used synomously with "grinding year".

COMMERCIAL SUGAR: The final sugar product produced by Hawaiian cane sugar factories. The sugar is synomously termed "commercial raw sugar" or "raws".

DIFFUSER JUICE: Cane juice leaving the cane diffuser and entering the juice evaporators.

EXHAUST STEAM: Steam leaving the process turbines (Buster, Fiberizer, Dewatering Mi11, Boiler Feedwater Pump) and the low pressure extraction of the turbogenerator at $13 \mathrm{psig}, 246^{\circ} \mathrm{F}$.

FIELD CANE: Cane as hauled in from fields before washing and removal of mud, rock and trash, usually expressed in tons.

FIRM POWER: Electrical power supplied at predetermined levels on a continuous and fixed schedule.

LIVE STEAM: Steam extracted from the turbogenerator at 160 psig.

MASSECUITE: A mixture of sugar crystals and mother liquor which occurs from crystallization.

MOTHER LIQUOR: The molasses separated from sugar crystals in massecuite.

PREPARED CANE: Cane leaving the cleaning plant after removal of mud, rock, and trash.

PRESS JUICE: Juice extracted from the wet bagasse leaving the cane diffuser by the dewatering mill.

POL: Percent sucrose by weight as determined by single polarization of a normal weight of a sugar product. 


\section{DEFINITIONS (contd)}

PURITY: Sucrose per 100 total solids.

SUCROSE: The disaccharide $\mathrm{C}_{12} \mathrm{H}_{22}{ }^{0}{ }_{11}$ commonly known as sugar.

SYRUP: Concentrated clarified juice before crystallization.

TPCH: Tons prepared cane per hour. (See Prepared Cane.)

TRASH: Cane leaves, tops, dead and soured cane, and other fibrous material harvested with the cane.

VAPORS: Steam liberated from boiling cane juice. 


\section{ABBREVIATIONS}

DGE: Division of Geothermal Energy, USDOE

DL\&R: Department of Land and Natural Resources, State of Hawai i

DOT: Department of Transportation, State of Hawaii

DPED: Department of Planning and Economic Development, State of Hawai

EIS: Environmental Impact Statement

EISPN: Environmental Impact Statement Preparation Notice

EQC: Environmental Quality Commission

FTT: Fahrenheit Total Temperature

HECO: Hawaiian Eleçtric Company

HELCO: Hawaii Electric Light Company

HGP: Hawaii Geothermal Project

HGP-A: Hawai Geothermal Project Well A. (Named posthumously in honor of Dr. Agatin Abbott, the original drill task group head.)

HIG: Hawaij Institute of Geophysics

HRS: Hawaii Revised Statutes

HVNP: Hawaii Volcanoes National Park

IDC: Intangible Drilling Cost

KGRA: Known Geothermal Resource Area

NPV: Net Present Value

ROI: Return on Investment

USDOE: United States Department of Energy

USGS: United States Geological Survey 


\section{Section 1}

\section{INTRODUCTION}

Since the early 1970's the United States has become increasingly dependent on foreign energy sources. This is particularly true of Hawaii which presently derives 92 percent of its energy from imported fuel oil and its derivatives, and historically has always had a negative energy balance of trade. In an era of relatively inexpensive fossil fuel costs, the economic drain of this imbalance was not significantly evident. But with the rapid escalation of oil costs to over $\$ 500$ million annually, and attendant rise in commodity prices, government and industry's view of Hawaij's inordinate dependence on fuel importation has been dramatically affected.

Aside from the gravity of the economic implications, such a preponderous dependency on a single source of energy overrides all other arguments, and points the way to strive for some degree of energy self-sufficiency. Hawaij's precarious position dictates that it can no longer depend on - maintaining a status quo in the face of ever declining fuel oil reseryes.

Faced with this almost total commitment to energy importation, the U. S. Department of Energy, the State of Hawaii and Hawaii County have embarked on an ambitious program of identifying and developing alternate energy sources indigenous to the Islands. Work is currently progressing in biomass, wind, solar, and ocean thermal conversion. One other source of particular promise to Hawaii is geothermal energy. 


\subsection{AUTHORIZATION}

This project has been sponsored and funded by the United States Department of Energy, Division of Geothermal Energy. The contract life extended over a twelve month period which began on February 20, 1978 and terminated February 20, 1979. This study explores the feasibility of various alternatives for the utilization of hydrothermal fluids at the Puna Sugar Company cane processing factory and its ramifications on production, equipment, economics, and institutional regulations.

Puna Sugar Company was selected by the Geothermal Division to accomplish the engineering and economic analysis for the project. W. A. Hirai and Associates of Hilo, Hawaii in turn was retained as the subcontractor by Puna Sugar Company to provide expertise in selected areas of the project.

\subsection{STATEMENT OF OBJECTIVES}

The objective of this project is to conduct an engineering and economic analysis to determine the feasibility of using moderate temperature hydrothermal fluids in the processing of cane sugar. Included among the tasks are the following:

- Conduct an inventory and analysis of the entire sugar cane factory operation to obtain baseline mass and steam balances. Calculations include mass balances for sugar cane, juice, syrup, raw sugar, molasses, bagasse, process hot water and steam.

- Determine the production capacities of the factory equipment and correlate these to the mass and steam balance. Conduct detailed studies of the diffusion, clarification, evaporation, crystallization and centrifuging stations to obtain the mass and steam balances. 
- Conduct an assessment of equipment and materials to determine the effects of geothermal fluids on the variety of materials that are used in the process equipment.

- Use a modified plant layout showing replacement requirements to illustrate functions and costs attributed to hydrothermal fluids.

- Estimate material, construction and design costs for the various alternatives. These costs are used in calculating the capital investment requirements and the rates of return.

- Evaluate the utilization of geothermal fluids in cane sugar factory operations in terms of environmental and sociological impacts with attendant cost estimates made to mitigate noise, air, and other forms of pollution. Special emphasis is placed on the effect of noise, $\mathrm{H}_{2} \mathrm{~S}$, and effluent fluids.

Advise residents within the proximate area of the proposed project through a public informational meeting.

Recommend potential drilling sites or additional reservoir assessment based on information from existing surveys and from further studies planned, if available prior to the end of this study.

- Estimate reservoir potential and associated well costs using data available to this study to complement the factory study. Cost estimates for all phases of implementation, from reservoir assessment to drilling and utilization is incorporated in this study. 
- Perform an economic study utilizing conventional techniques to determine system economic feasibility. Discounted cash flow analyses with calculations for internal rates of return for the various options will be delineated. These analyses show the economic viability of each alternative.

- Investigate and describe the institutional factors associated with legal and regulatory matters.

- Submit reports as necessary to fulfill all USDOE requirements.

\subsection{METHOD OF ACCOMPLISHING THE STUDY}

The approach taken at the onset of this project was to develop costeffective alternatives which retained system reliability and quality control performance. Alternatives not meeting this preliminary requirement were immediately rejected from further evaluation.

Initial efforts in the study were concentrated within the Puna Sugar factory domain to establish rapidly, the various possibilities and magnitudes that were available for any geothermal retrofit. All major groups of equipment were inventoried to identify possible retrofit candidates. Factory operating data was then collected from production reports and field measurements. From the data, process flows were delineated and mass and heat balances calculated for the various factory baseline operating modes.

A number of geothermal resource options were evaluated based on practical cane sugar process plant retrofit designs. Out of these plans evolved the geothermal utilization alternative recommended by this study. 
The recommended scenario includes a potential resource near the successful HGP-A well in the East Rift Zone of Kilauea and transmission of that resource over a considerable distance to the Puna Sugar factory. The potential resource area was evaluated from results of previously completed surface exploratory tests in the area and a drill site was recommended.

During the selection of the drill site, resource transmission corridor, and process system, cost estimates were continually developed to insure that the most appropriate alternative was finally selected. The economics were then evaluated based on the technical cost requirements as well as the costs associated with mitigating environmental, institutional and natural hazard risk concerns.

\subsection{ORGANIZATION OF THE REPORT}

Section 2 presents the summary, conclusions, and recommendations of the report. The following sections, 3 through 11, detail the various aspects that resulted in the conclusions and recommendations of Section 2. Backup material for the sections are included in the appendices. 


\section{REFERENCES}

1-1 Energy Use in Hawaii, Department of Planning and Economic Development, State of Hawaii, Nov. 1977. 
Section 2

SUMMARY, CONCLUSIONS, AND RECOMMENDATIONS

The purpose of this project was to assess the potential use of geothermal resources in the Puna Sugar Company cane sugar process plant. Following an inventory of the process equipment and thermal system, a well site, geothermal steam treatment, resource transmission and factory retrofit program was synthesized. Further, an economic evaluation was conducted to determine the proposal's financial feasibility. Impacts of other factors, such as environmental and institutional concerns, were also addressed.

\subsection{BACKGROUND}

In recent history only one geothermal well, designated HGP-A, has been drilled in the State of Hawaii. This well is a singular success, producing a liquid dominated resource of commercial quality. Test results point to a substantial reservoir and related exploratory investigations indicate other high potential resources on the Island of Hawaii.

Geothermal Exploration and Development Company (GEDCO), a Hawaiian based firm, has received an agreement in principle from the State Board of Land and Natural Resources to drill a maximum of six geothermal wells in the Puna district, in relatively close proximity to the HGP-A well. Recently, foreign enterprises have also expressed interest in developing the geothermal resource of the Puna area. 
The Hawai state government has recognized the potential of alternative energy resources, and in particular the prospects of geothermal energy. An extensive state exploratory program haș been conducted on the lower section of Kilauea volcano's East Rift Zone, culminating in the successful HGP-A well. Other exploratory work is continuing. A well head generator facility has been funded and on-stream operations are scheduled for 1980. Simultaneously, the State legislature has enacted several laws relating to alternate energy, which specifically encourages their development.

\subsection{SUMMARY}

The major findings of this study are listed below in the order of development by section.

\subsubsection{Baseline Plant Facility and Process Description}

The Puna Sugar Company, with offices in Keaau, Hawaii, is a wholly owned operating subsidiary of Amfac, Inc. Its activities, as an integrated cane sugar farming and processing concern, extend throughout the Puna district of the Island of Hawaii. The Puna Sugar 4000 ton cane per day process plant annually consumes over $700 \times 10^{9}$ Btus to produce 60,000 tons of commercial raw sugar, 18,000 tons of final molasses and nearly $70,000,000 \mathrm{kWh}$. Of the total electric production, 38,000,000 kWh are sold to the public utility, HELCO, and the remainder is consumed within the sugar plant.

Typically, the fibrous dewatered residue of the cane plant, called bagasse, is fired in a boiler to generate steam. The entire steam production is directed to a turbogenerator for electric power generation. A portion of the steam is automatically extracted from the turbogenerator 
to meet the demands of the cane factory, while the steam remaining in the turbine is condensed.

In proximity to the cane factory are a number of small plants that could possibly use geothermal resources. These include a nut processing plant, a fruit packer, and a slaughter house operation.

\subsubsection{Reservoir Potential}

The origin of geothermal resources on the island is magmatic heat. The island itself is the product of volcanic activity from the five mountain masses which collectively form the Island of Hawaii. Of the five volcanoes, three are still active.

The well site selected for this project is in the East Rift Zone of Kilauea, one of the active volcanoes. The site is near the only successful geothermal well in Hawaii, HGP-A, but the reservoirs are distinct and separate.

Much of the lower East Rift has been intensively studied and explored. Surface indications at the proposed well site, when compared with those of the HGP-A well area, indicates equal or better subsurface geothermal resource potential. Nevertheless, an exploratory hole has yet to be drilled in the proposed area, and at least one must be drilled to prove the resource. For lack of confirming test data, the general well characteristics based on the HGP-A well is used in the study.

\section{2,2.3 Design Synthesis Criteria}

The study is based on an annual cane production of $1,185,000$ tons. To process this cane in a 46 week operating year, the cane factory must process 4000 tons of prepared cane daily. The operation begins on 
Monday and continues on a 24 hour schedule until Saturday. Weekends are consumed in cleaning and minor repairs.

Due to the firm electric power sales arrangement, the steam and electric generation facilities operate on a somewhat different schedule. This arrangement is more akin to a utility type operation, with a continuous four-shift schedule.

Both the process plant and the boiler-generator facility commence yearly operations about the first of February, with the cane factory terminating its activity ten and a half months later in mid-December. The boiler and turbogenerator operate for another two weeks, for a total of 48 weeks, and then stop for annual repair and maintenance.

\subsubsection{Functional Design}

The substitution of geothermal steam for process steam results from the supplemental geothermal process originating in the East Rift Zone of Kilauea volcano. Several interrelated activities and consequences are manifested in the development and retrofitting of the geothermal program with the existing cane processing plant. These relationships are listed below.

- The proposed well site is located near the HGP-A well, some 16 miles from the Puna Sugar factory in Keaau. Four production wells plus an injection well will be drilled at the site, with the production wells producing a liquid dominated flow at 300 psig.

- Brines are separated and immediately reinjected into the substrata.

- The geothermal steam is used to boil clean water in evaporators. 
Approximately 175,100 pounds per hour of steam at 240 psig is produced by the three evaporators for transmission to the Puna Sugar factory.

- Noncondensible gases associated with the geothermal steam are vented from the evaporators at the well site and incinerated. The incineration process is utilized primarily to oxidize the odoriferous hydrogen sulfide to the less perceptible sulfur dioxide. Sulfur dioxide is then recovered for use in the Puna Sugar juice processing.

- Steam at 240 psig leaves the well site for the cane process plant in a 16 mile long, 20 inch diameter pipe. A total of 176,300 pounds per hour is initially transmitted, with most of the steam produced by the evaporators and the difference by a small boiler in the hydrogen sulfide conversion system.

- Pipeline flow resistance and thermal losses both take their toll in the steam transmission to the cane factory. Approximately 80 psi pressure is lost due to resistance and 14,100 pounds of steam per hour condense as a result of heat dissipation. The condensed steam is rejected through steam traps.

- The factory receives 162,200 pounds of steam per hour at 160 psig from the transmission pipeline. After moisture separation, this steam immediately enters, and is absorbed by, the process steam system.

- Due to the introduction of geothermal steam, usage of supplemental fuel oil that is normally fired in the boiler can be eliminated during the 46 week cane production campaign. Only 
When the cane process plant is stopped for more than two consecutive days is it necessary to fire the boiler on oil.

- Appropriate modifications to the turbogenerator will allow the cane process plant to accept more geothermal steam than the process requires. The extra steam will enter what presentiy is the 160 psig extraction port of the turbogenerator. This additional steam, plus bagasse fired steam not needed for process, are used to generate more electricity for power sales. A base load export level of $12.32 \mathrm{MW}$ is proposed which will produce about $100,000,000 \mathrm{kWh}$ annually, of which $68,000,000 \mathrm{kWh}$ is attributable to geothermal energy.

- The combination of fuel oil purchase savings, additional revenues from larger power export sales and sale of $\mathrm{SO}_{2}$ offsets the costs of the geothermal system.

- A nominal manning increase is projected with geothermal implementation. Eight operating personnel are charged to the system while an additional 1.5 men are allocated for maintenance.

\subsubsection{Project ScheduTe}

A five year period, from 1978 through 1982, is allocated for the proposed system planning, design, and construction schedule. The initial phase of the work extending through 1978 and early 1979, is this feasibility study. Further detailed evaluation is to be followed by a project commitment in principle prior to the end of 1979. Drilling and construction will begin in 1981, with commercial geothermal production in early February, 1983.

\subsubsection{Risk Assessment}

Because the proposed well site is located in an active rift zone, the 
most immediate concern is associated with crustal and magmatic activity. These natural hazards can be catagorized as direct and indirect hazards. Within the former classification are falling rock fragments, lava flows, drifting volcanic gas, and particle-and-gas clouds. Indirect hazards are manifested by subsidence, surface rupture, earthquakes, and tsunamis. The impacts of natural hazards on the proposed system vary with location and type.

Exposure and accessibility will invite vandalism. Since the project area extends for 16 miles, damage through vandalism may be a real problem and is of concern.

Well blowouts during drilling and production periods are another risk factor that must be evaluated. Conservative design and proper construction techniques minimize this possibility.

The risks associated with this system are greater than in an ordinary venture. Nonetheless, steam supply and electric power production are critical to the viability of the proposal. Fortunately, the Puna Sugar steam boiler has adequate capacity to make up for any loss in geothermal steam. Steam supply at the factory then is available, regardless of the reliability of the geothermal system.

\subsubsection{Economic Analysis}

Puna Sugar and Amfac corporate policy is to initially evaluate a project based on internal financing. The economic analys is for this proposal is completed on that assumption, although in practice, implementation would probably be financed using other available methods. The project has a $15.1 \%$ return on investment, which marginally meets Amfac's minimum ROI, 
but further corporate evaluation must be completed before a commitment is made. Other features of the analysis are related below.

- A 20 year project life (1983-2002) is assumed, with costs and revenues escalating annually at various rates ranging from $7 \%$ to $8 \%$. The 1982 installed cost for the project in 1978 dollars is $\$ 21,000,000$.

- The discounted cash flow method is utilized in the evaluation.

- A depreciation life of 18 years is used in conjunction with accelerated depreciation schedules. No salvage value is attached to the equipment after 20 years.

- Certain allowable tax benefits are incorporated in the analysis. These include a $20 \%$ investment tax credit, use of intangible drilling costs, and percentage depletion allowance.

While the project may be marginal from a private financing perspective, there are important public economic benefits that should be considered. These are primarily financial, as accumulated benefits to the public in differential electricity costs plus royalty and tax income over the life of the project is more than $\$ 79,000,000$. Serious consideration should be given to alternative ownership and financing arrangements, as definitely, the cost-benefit relationship weighs heavily in the public's favor.

\subsubsection{Environmental Concerns}

Two primary areas of environmental concern are the effects of geochemical toxicants and the impact the project has on the social values of the community. Of the two, geochemical toxicology is much more precise in that its effect can be quantified readily. Its influence on the environ- 
ment can be categorically classified as negligible.

Changes to the cultural environment are much more difficult to predict. The consequences will probably be minor from the specific project. However, as the geothermal industry develops on the Island, the cumulative effect of several projects on the Puna district is not known, but it will certainly be more than minor.

\subsubsection{Institutional Concerns}

A number of institutional concerns appear in this project. A major consideration that should be resolved is geothermal rights ownership. For the proposed evaluation, there probably will be no significant effect, since the geothermal rights at the recommended well site are unquestionably reserved to the State.

The permitting process at first glance appears formidable. No less than 16 permits are required before the completion of implementation. However, the State and County administrations have exhibited a positive pose toward the development of alternate energy resources. Perhaps more than any other singular factor, the attitudinal stance of government will be the impetus toward encouraging new resource development.

The project economics are marginal. One of the fundamental reasons is that the electric rate structure for electric power sales is depressed. Again, a positive posture by government in determining a fair and equitable fee for electricity will promote evolvement of alternative energy programs.

\section{CONCLUSIONS AND RECOMMENDATIONS}

The implementation of the proposed system will have many advantages for Puna Sugar, the State, the County, and the community. Based on the 
findings of this study, the following conclusions are submitted, as well as recommendations for immediate action.

- Geothermal resource production and utilization at the Keaau process plant of the Puna Sugar Company is technically feasible.

- The $\$ 21,000,000$ system barely meets Amfac's minimum return on investment criteria. However, under the present Amfac sugar related investment climate, the project will not be internally funded,

- $\quad$ ther alternative financial plans, including second party participation, must still be evaluated.

- Partial government ownership in the project would likely be a positive incentive for cooperative private investment. A specific example is government ownership and operation of an energy corridor from the East Rift Zone to Keaau, transmitting steam for a fee. This alone will reduce capital requirements of the project by $60 \%$.

- Government participation may be contingent on the resolution of the geothermal ownership rights question.

- Interested groups should seriously address and resolve the geothermal ownership rights impasse. There apparently is some reluctance by government and private investment groups to risk capital without this resolution.

- There will be substantial public benefits that will accrue from the project. Royalty payments, taxes and differential electric rates will contribute more than $\$ 79,000,000$ to the community over the 20 year program.

- The project can be a commercial reality by early 1983 . 


\section{Section 3}

\section{BASELINE PLANT FACILITY AND PROCESS DESCRIPTION}

The sugar industry has historically occupied a prime role in the economy of the State of Hawaii. Revenues have been as high as $\$ 685,000,000$ annually, with a present direct employment of 8,930 persons. Including support services, it is estimated that sugar production employment approaches 30,000 .

Within the Puna district of Hawaii County, many new diversified agricultural crops have flourished in recent years, including papayas and anthuriums. Sugar cane, however, continues to be the major industry in this predominately agrarian district.

\subsection{LOCATION}

The Puna Sugar Company is located in the Puna District of Hawai County. While its leased and fee simple lands are scattered throughout the district, the buik of its land holdings are in the Keaau-Mountain View and Pahoa-Kapoho sections. Sugar cane is grown in these two separate areas and hauled by truck to a central cane processing factory located near the town of Keaau. Figure $3-1$ indicates the relative setting of the Puna Sugar lands with respect to the Puna district and the Island of Hawaii. Of secondary interest in Figure 3-1 is the locations of historic lava flows (post 1778).

\subsection{CORPORATE STRUCTURE AND HISTORY}

Puna Sugar Company was incorporated as 01aa Sugar Company, Ltd. in 1899, 


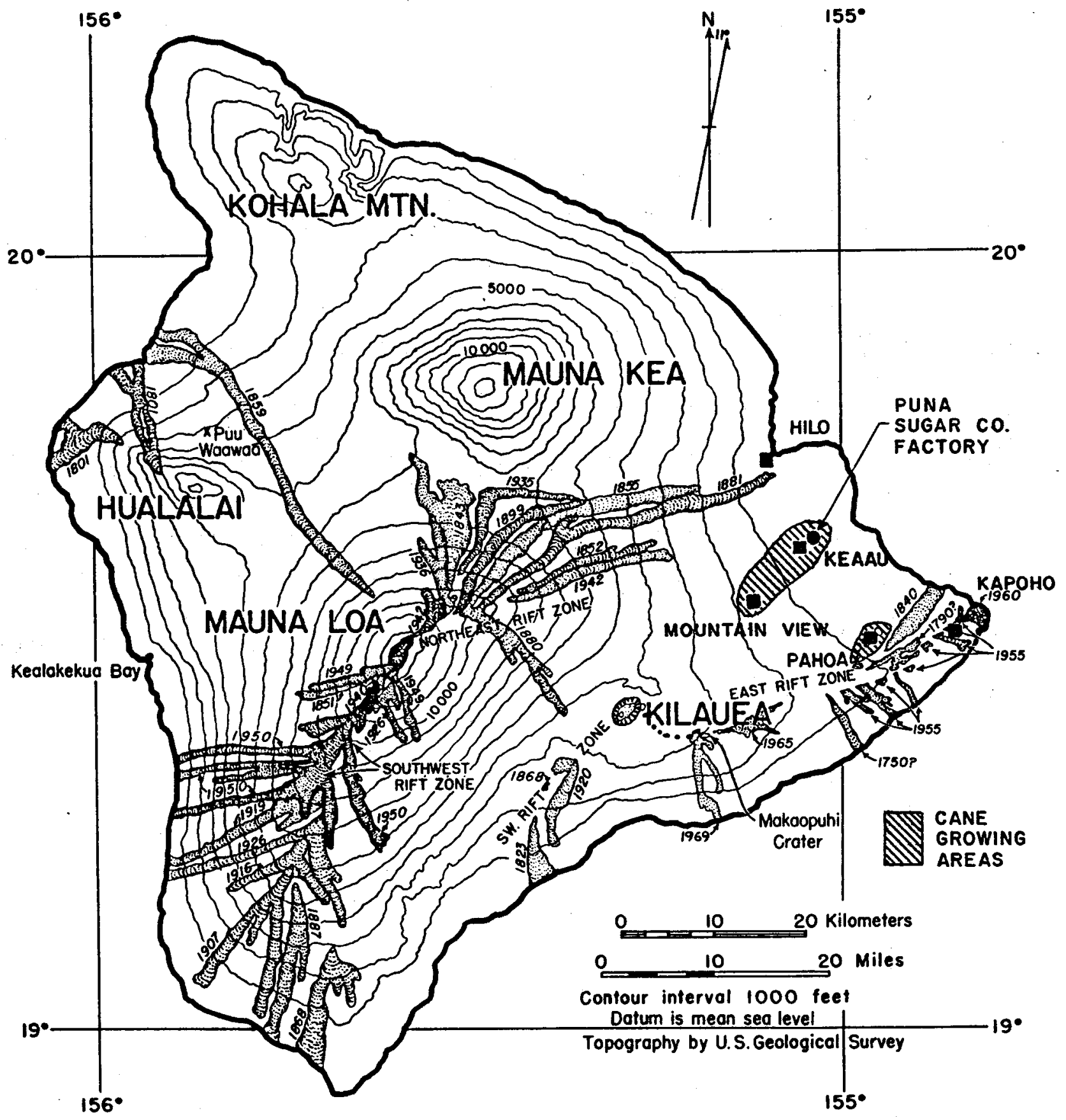

Figure 3-1

Map of the Island of Hawaii

(County of Hawaii) 
a year after the Republic of Hawai $i$ was annexed by the United States. In 1960, the name was formally changed to Puna Sugar Company, Ltd. to reflect more accurately Puna Sugar's identity and association with the entire Puna district.

Today, Puna Sugar is a wholly owned and fully operating subsidiary of Amfac, Inc., with operating offices in Keaau, Hawaii. Amfac's association with Puna Sugar began in 1919 when it became its agent, transacting business on a commission basis. Puna Sugar stock was gradually acquired by Amfac over a period of years and in 1968, the Puna Sugar Company stockholders voted to merge their company into Amfac.

Two years after incorporation the first cane crop was milled, producing 1150 tons of sugar. Production has gradually increased since then, and the company now grows and harvests sugar cane on more than 13,000 acres in the Puna district. In addition, it purchases cane from independent growers who cultivate an additional 2,000 acres. A11 cane is processed in the company owned facility at Keaau, which now produces nearly 60,000 tons of sugar annually.

The history of Puna Sugar Company has been marked by a gradual evolution in its operations and character. Many innovative concepts have been tried in an effort to raise corporate returns. For a time mulch paper, manufactured from bagasse, was an important by-product. It was utilized as a covering in the fields to reduce sugar cane weeding costs.

Cane was originally transported to the mill by sluicing flumes and railroads. During the $1930^{\prime} \mathrm{s}$, the company operated 72 miles of flumes and used 60 miles of railroad lines to move its cane from the more distant 
fields. Today all cane transport is conducted via large specially designed cane-haul trucks, much of it on company owned roads.

The late 1940's and early 1950's saw a concerted effort toward field mechanization using new methods of cultivating and harvesting cane. As a result, manpower on the plantation was drastically reduced from 2400 in 1938 , to 1350 in 1949 , to less than 500 by the late $1950^{\prime} \mathrm{s}$. Today, 430 employees form the permanent work force that cultivates, harvests, and processes the cane to sugar.

In 1955, a flank eruption along the East Rift Zone of Kilauea volcano spelled near economic disaster to the company. Nearly 2000 acres of sugar cane land in the Kapoho area were burned or damaged. Over 1500 acres of that was directly innundated by lava flows. Estimated loss of crops and land totaled well over three million dollars.

Again in 1960, lava began pouring out on the East Rift Zone of Kilauea, covering 250 acres of cane land. An additional 600 acres were buried in cinder fallout up to six feet deep. Losses in sugar totaled approximately one million dollars. The Kapoho cane producing areas never recovered from this second devastation and the entire area was later abandoned from further cane cultivation.

In 1970, a major change in the factory operation was initiated, and over nine million dollars of equipment was capitalized. The conventional milling train which extracted cane juices using large rollers under heavy pressures was replaced by the cane diffuser. The diffuser uses an entirely different process of juice extraction by leaching. In addition, a single high pressure boiler and turbogenerator replaced several 


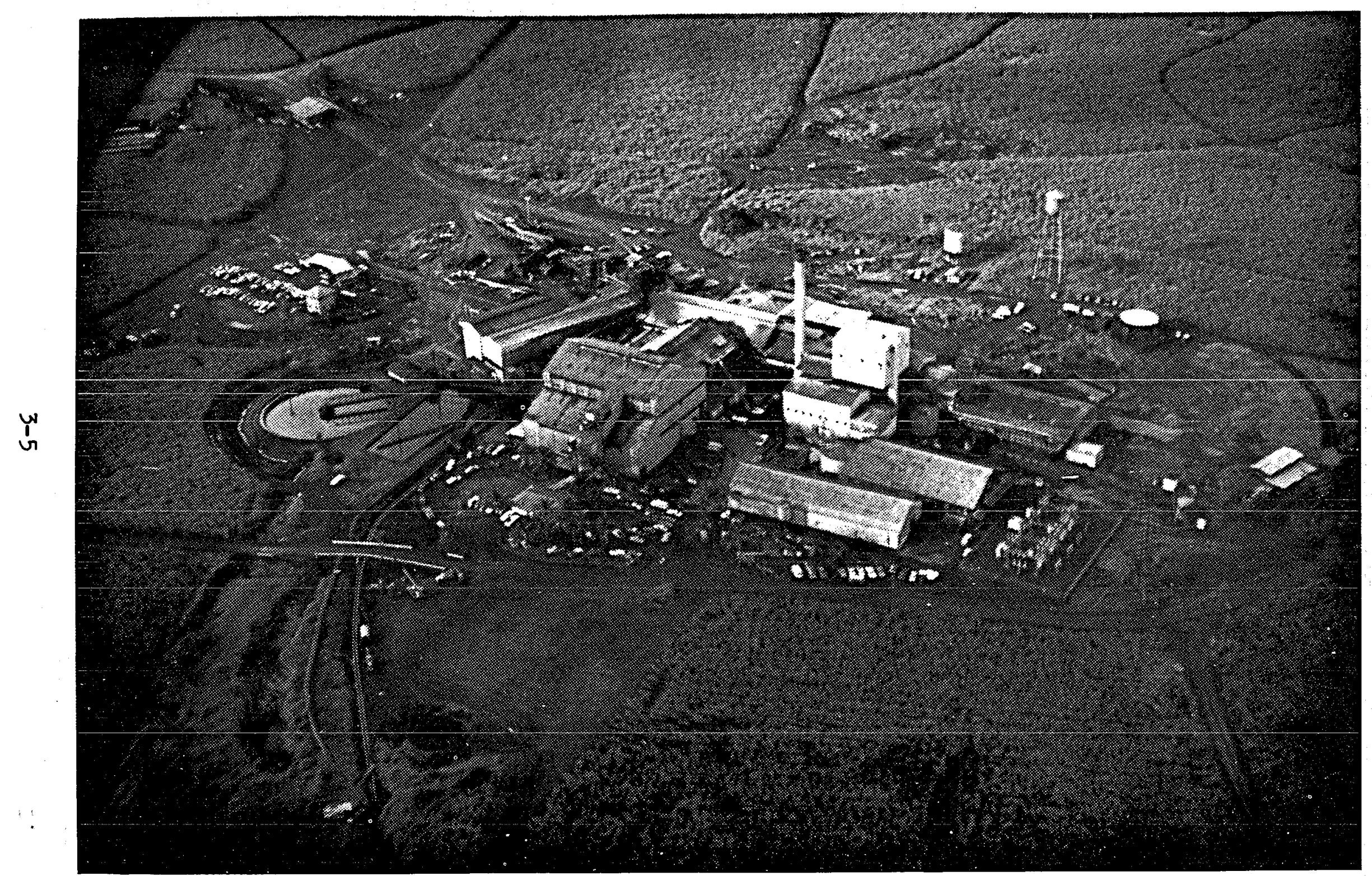

Figure 3-2

AERIAI VIEW OF THE PUNA SUGAR PROCESS PLANT 


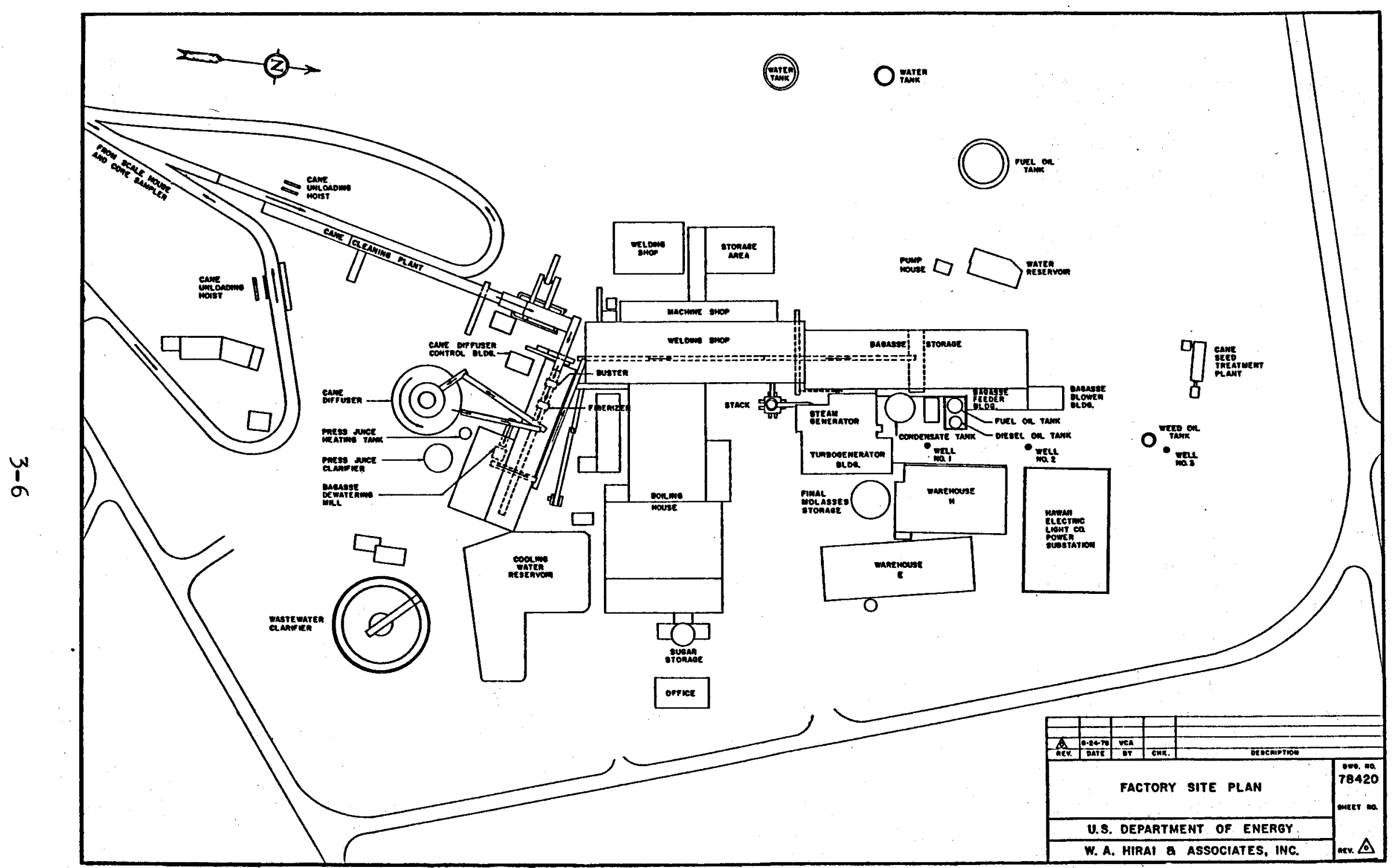

Figure 3-3

ractory Site Plan 
antiquated units. All bagasse and fibrous cane trash was burned to produce steam for power generation. Finally, in 1971, a 20 year agreement was signed with the Hawaii Electric Light Company, which provided for the export of firm power into the island wide electrical grid.

\section{3 BASELINE PLANT FACILITY}

The Puna Sugar Company cane sugar factory is the single major agriindustrial complex in the Puna district. Originally built in 1901, it is situated on a 150 acre plot near the community of Keaau. Figure 3-2 is an aerial perspective of the factory area, while Figure 3-3 depicts the factory plot plan. Immediately adjacent to the factory, but outside the plot plan area, are the field equipment maintenance facilities and the corporate operating offices of Puna Sugar.

Cane sugar processing is a highly energy intensive process, requiring more than 5800 Btus to produce a pound of sugar. Puna Sugar Company's medium sized 4000 ton prepared cane per day factory thus consumes well over $700 \times 10^{9}$ Btus annually, making it and the other sugar factories, one of the major energy consumers in the County. Fortunately, bagasse, which is the fibrous waste product of the sugar extraction process, has a net positive heating value and provides most of the energy requirements in cane processing.

\subsection{BASELINE PROCESS DESCRIPTION}

The factory is a part of an integrated farming and processing complex geared to growing, harvesting and processing sugar cane. The end products are commercial raw sugar, final molasses, and exported electricity.

The entire annual production of 60,000 tons of commercial raws are shipped to Crockett, California where it is further processed to the familiar 
$C \& H$ refined sugar found on the supermarket shelves of the western United States. Final molasses is shipped throughout the continental United States and is used for a variety of purposes, but primarily as a nutrient base for cattle feed. Electricity is used for in-plant demands. In addition, power is sold to the electric utility, Hawai Electric Light Co. (HELCO), on a firm power basis. Terms of the contract dictate this power supply at predetermined levels throughout a 48 week annual period. Figure $3-4$ is a schematic representation of these process flows, which has been developed from data documented in Appendix $A$.

\subsubsection{Cane Weighing and Sampling}

Sugar cane is simultaneously harvested from several fields which may have different ownerships. To avoid the inefficiency of physical cane separation at the factory, the 20 ton cane loads are accurately weighed and sampled in the incoming trucks. All cane is then off-loaded and mixed at the cane cleaning plant.

\subsubsection{Cane Cleaning}

Mechanized harvesting methods in the fields, while reducing labor requirements several orders of magnitude, have increased several folds the weight and bulk of extraneous material harvested. This extraneous material composed largely of soil and rocks, is carried to the factory and must be removed prior to juice extraction.

Through a series of hydraulic bath gravity separators, agitating rolls, and water sprays, the extraneous material is separated from the cane. At this point the material is known as prepared cane and its flow rate is the basic indicator of plant production. For Puna Sugar Company, the 


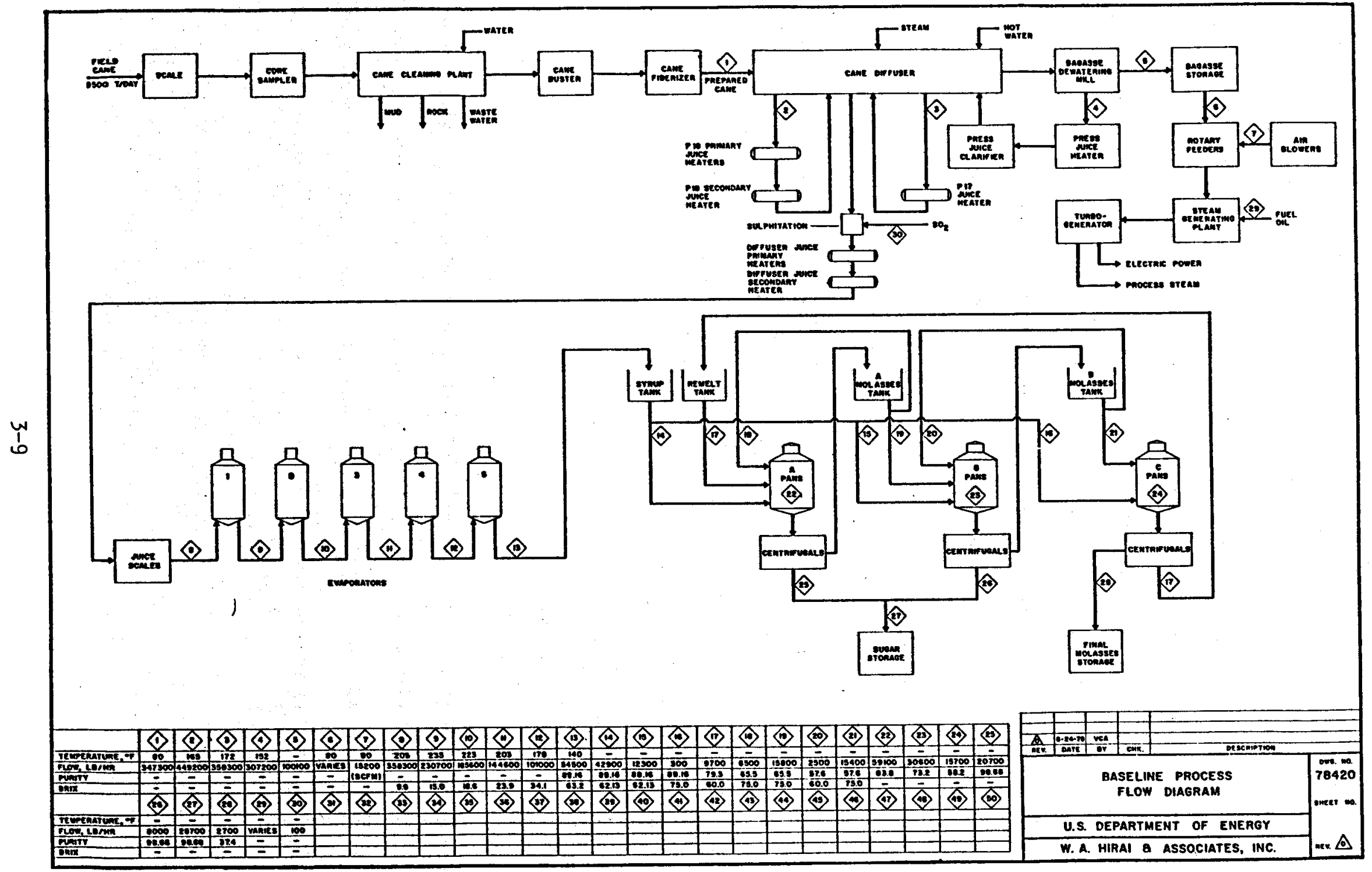

FIGURE 3 - 4

BASELINE PROCESS FLOW DIAGRAM 
plant baseline capacity is approximately 4000 tons per day and for this project, a flow rate of 175 tons prepared cane per hour is used.

Spent water from the juice process barometric condensers is used and recycled several times in washing the cane. Waste water from the cane cleaning plant sluices the extracted soil and gravel to a land reclamation area. Rocks from the cane cleaner facility is hauled by trucks to the same area and contributes to the reclamation program that annually converts 40 acres of waste land to productive sugar crop lands.

\subsubsection{Cane Preparation}

The prepared cane from the cane cleaner is then conveyed to and shredded by the cane buster and fiberizer. These are large devices each driven by a $1000 \mathrm{HP}$ back pressure steam turbine, and fitted with rotating impact hammers that shred the cane and expose the cane stalks' sugar ladened cells to the leaching process in the diffuser.

\subsubsection{Cane Diffusion}

From the buster and fiberizer, cane is moved to the cane diffuser. Actually diffusion is a misnomer, for what really occurs in the diffuser is a leaching process. Hot water is added to the cane blanket immediately prior to the cane leaving the diffuser. The water percolates through the cane blanket and is collected as a dilute juice and recirculated further upstream of the moving blanket of cane. In this counter current fashion, the dilute juice gradually leaches out most of the sugars in the cane. At several points in the juice leaching process, the recirculating juice is heated by direct and indirect contact heat exchangers. This is done to maintain an elevated cane blanket temperature, which aids in the percolation and leaching process. 


\subsubsection{Juice Sulfitation}

After the final juice leaching stage, the juice is limed and then neutralized by introducing $\mathrm{SO}_{2}$ gas into the juice steam. While the sulfitation process is used extensively in other cane sugar producing areas of the world, it was only recently introduced to the Hawaiian sugar industry in 1977 by Puna Sugar Company. The effects of sulfitation are retained through the processing stages and result in higher quality sugar crystals and increased sugar recovery.

\subsubsection{Juice Heating}

The diffuser juice, after sulfitation, is preheated and stored in a surge tank. This buffer serves to stabilize the process flow and insure better quality control.

\subsubsection{Juice Weighing}

All juice is weighed after leaving the juice surge tank and before entering the evaporation stage. The juice weights serve as one of the important bases of subsequent process control.

\subsubsection{Juice Evaporation}

The multiple effect juice evaporator set consists of five stages with both steam and juice in a feed forward arrangement. Juice is concentrated in the evaporators from an initial concentration of $10 \%$ solids to a syrup of $65 \%$ solids. The major usage of process heat occurs at this station with about $700 \times 10^{9}$ Btus of process steam being expended annually.

\subsubsection{Sugar Crystallization}

Crystallization of sugar occurs in the pans with the further concentration of the syrup. This mechanical mixture of crystals and heavy mother liquor 
is later separated by centrifuges. The sugar thus removed is stored and later shipped to the $\mathrm{C}$ and $\mathrm{H}$ refinery in California. The mother liquor, now known as molasses, is recycled back into the crystallization process several times before ultimately being rejected as final molasses. The final molasses also is accumulated and subsequently shipped to the continental United States.

\subsubsection{Bagasse Dewatering}

Returning to the other material stream of the diffuser, the cane as it leaves the diffuser, becomes known as bagasse. This fibrous residue of the diffusion process must be dewatered to raise its net heating value and recover more of the remaining residual sugar. A dewatering mill driven by a $500 \mathrm{HP}$ back pressure steam turbine squeezes and removes much of the water from the bagasse. Bagasse moisture drops from $80 \%$ to less than $50 \%$. The press juice thus removed is heated and pumped to a multi-tray gravity clarifier. The overflow product from the clarifier returns to the diffuser while the underflow is removed to the land reclamation project.

\subsubsection{Bagasse Storage}

The dewatered bagasse is conveyed to an enclosed storage building by a tandem of belt conveyors. Storage capacity for the nearly 20,000 square foot building is 900 tons. During the process week, bagasse not immediately required for combustion is stored in the building. However, most of the bagasse is metered almost immediately into pneumatic conveyors and fired in the boiler furnace.

Bagasse enters the pneumatic conveying system near the bagasse storage building. Gates in the bottom of a drag slat conveyor drop bagasse down 
an enclosed chute to eight rotary bagasse feeders. These feeders consist of an internal rotating drum with a peripheral surface of studded tines. As the drum rotates within an outside she11, fixed quantities of bagasse pass between the drum surface and the outside she11. The bagasse feed rate is therefore a function of the feeder drum rotational speed which is controlled by a variable speed motor.

Bagasse exiting each feeder drops into a rotating airlock and is conveyed through pipes into the boiler by air from positive displacement blowers.

During weekends and unscheduled factory stops, stored bagasse is reclaimed by means of a wheeled front end loader which pushes the bagasse to the metering point.

\subsubsection{Steam Generation}

The boiler is a 282,000 pound per hour capacity unit capable of generating superheated steam of 875 psig at 760 degrees FTT. A1l steam generated passes to a double automatic extraction turbogenerator. Bagasse supply has been consistently short of boiler demands and supplemental amounts of fuel oil are routinely fired to meet the power commitments of the HELCO contract.

The Combustion Engineering VU4OS boiler is a two-drum, water wall unit with approximately 14,240 square feet of convective and radiant heating surface provided in the water walls. Furnace volume is 17,000 cubic feet. Additionally, the boiler is equipped with a 16,800 square foot tubular air heater, a 53,000 square foot Ljungstrom regenerative air preheater, and a 13,000 square foot economizer. Heating of the boiler feedwater is by a deaerating heater and a single boiler feedwater heater.

Bagasse is pneumatically conveyed and fired through eight burner openings 
into the furnace. Each burner nozzle is directed tangentially into the furnace box, with two burners mounted vertically at each corner of the boiler. Between the vertical pair of bagasse burners at the corners is a fuel oil burner, also mounted to fire tangentially into the furnace.

The majority of the bagasse is burned in suspension within the furnace box. Overfire air nozzles are located at various points to increase the controlled turbulence in the furnace and assure a complete burn. Undergrate air is added to cool the grate and provide additional air circulation in the lower section of the furnace. Only the heaviest fuel particles will fall and burn on the dumping grate.

All dust, flyash, and grate ash enter a water bath where the denser material settles out and is conveyed to a dump area immediately outside the bagasse storage building. This material is later transported to fill low lying areas in the cane fields surrounding the process plant. The remaining slurry is continuously pumped out and joins the water stream from the cane cleaning plant to the land reclamation area near the factory site. All boiler gases pass through a bank of cyclone flyash arrestors and exits to the atmosphere via a single stack.

\subsubsection{Electrical Generation}

The power plant at Puna Sugar Company is on a utility footing, operating continuously for 11 months of the year. Firm power commitments with HELCO provide for varying amounts of electrical energy to be exported into the island electrical network.

The power export commitment fluctuates throughout the week, ranging from a low of $4 \mathrm{MW}$ to a high of $6 \mathrm{MW}$. This export load, added to the in-plant 
load of 4.5 MW during sugar production periods and 2.5 MW on weekends, results in a busbar demand of 6.5 to $10.5 \mathrm{MW}$. Cumulative totals for the minimum electrical energy requirements from Puna Sugar to HELCO must be $38,000,000 \mathrm{kWh}$ annually or $792,000 \mathrm{kWh}$ weekly. The period of supply extends from early February to the end of the calendar year, with a four week consecutive shutdown allowance for normal repairs and maintenance in January. Power and energy commitments are negotiated yearly in June. These commitments through June, 1979 are documented in Table 3-1.

The turbogenerator is a $18,750 \mathrm{kva}, 13,800 \mathrm{~V}$ double automatic extraction unit built by General Electric Company in 1969. Maximum design throttle flow is 297,000 pounds per hour at 850 psig. Steam is automatically extracted for process demands at $160 \mathrm{psig}, 440^{\circ} \mathrm{F}$ and $13 \mathrm{psig}$, saturated. The remaining steam is condensed at 2 inches $\mathrm{HgA}$.

Condenser cooling water is provided by three $2800 \mathrm{gpm}$ vertical deep wells located near the powerplant and a pump located in an inclined Maui-type shaft, which produces 2,450 gpm. Each of the wells draws from the cold basal lens aquifier that has been estimated to be more than 800 feet thick.

At rated capacity, the condenser requires $10,800 \mathrm{gpm}$ from the condenser water pumps. This water exits the condenser and is used in the cane factory operations as barometric condenser cooling water which in turn, supplies the cane cleaning plant with wash water. Final use of the water is to sluice extracted soil and gravel from the cane washing and cleaning facility to the land reclamation site east of the factory.

\subsection{BASELINE STEAM AND CONDENSATE CYCLE}

The source of all steam heat is the single Combustion Engineering vu40S 
TABLE 3-1

PUNA SUGAR BASELINE EXPORT POWER AND ENERGY SCHEDULE

\begin{tabular}{|c|c|c|}
\hline Time & $\begin{array}{c}\text { Weekdays } \\
\text { (Mon-Fri) } \\
\text { (MW) }\end{array}$ & $\begin{array}{c}\text { Weekends } \\
\text { (Sat-Sun) } \\
\text { (MW) }\end{array}$ \\
\hline $\begin{aligned} & 12 \text { Midnight } \\
& 1 \\
& 2 \\
& 3 \\
& 4 \\
& 5 \\
& 6 \\
& 7 \\
& 8 \\
& 9 \\
& 10 \\
& 11 \\
& 12 \text { Noon } \\
& 1 \\
& 2 \\
& 3 \\
& 4 \\
& 5 \\
& 6 \\
& 7 \\
& 8 \\
& 9 \\
& 10 \\
& 11 \\
& 12 \text { Midnight }\end{aligned}$ & $\begin{array}{l}4 \\
4 \\
4 \\
4 \\
4 \\
4 \\
4 \\
4 \\
6 \\
6 \\
6 \\
6 \\
6 \\
4 \\
4 \\
4 \\
6 \\
6 \\
6 \\
6 \\
6 \\
4 \\
4 \\
4 \\
4\end{array}$ & 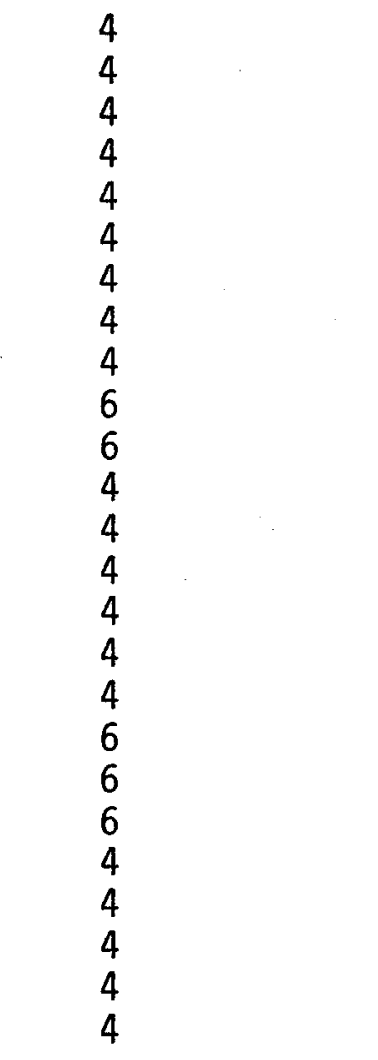 \\
\hline & $\overline{116}$ MWH per day & $\overline{106} \mathrm{MWH}$ per day \\
\hline
\end{tabular}

Notes:

1. Total weekly energy export is $792,000 \mathrm{kWh}$.

2. Total annual energy export over a 48 week operating year is $38,000,000 \mathrm{kWh}$. 
boiler. Figures 3-5 through 3-8 depict the various operating modes occurring throughout the week. Changes in flows are caused by the two export electrical demands and the factory operation. These are identified below.

- Sugar factory operating, 4 MW export

- Sugar factory operating, 6 MW export

- Sugar factory not óperating, 4 MW export

- Sugar factory not operating, $6 \mathrm{MW}$ export

\subsubsection{Steam Flow}

Boiler steam flow varies from 85,000 to 230,000 pounds per hour, depending on the mode of operation. The entire steam production from the boiler enters the turbogenerator which, in addition to generating electricity, acts as an expansion valve and supplies process steam at $160 \mathrm{psig}, 440^{\circ} \mathrm{F}$ (1ive steam), and $13 \mathrm{psig}$ saturated (exhaust) steam.

Live steam at $160 \mathrm{psig}$ is supplied to various demands. These are listed below:

- Fiberizer Turbine

- Buster Turbine

- Bagasse Dewatering Mill Turbine

- Boiler Feedwater Pump Turbine

- Molasses Tank Heating

- Makeup Evaporator

- Pressure Reducing Valve

- Feedwater Heater

- Fuel 0il Heater

- Fuel 0il Atomizing Steam 


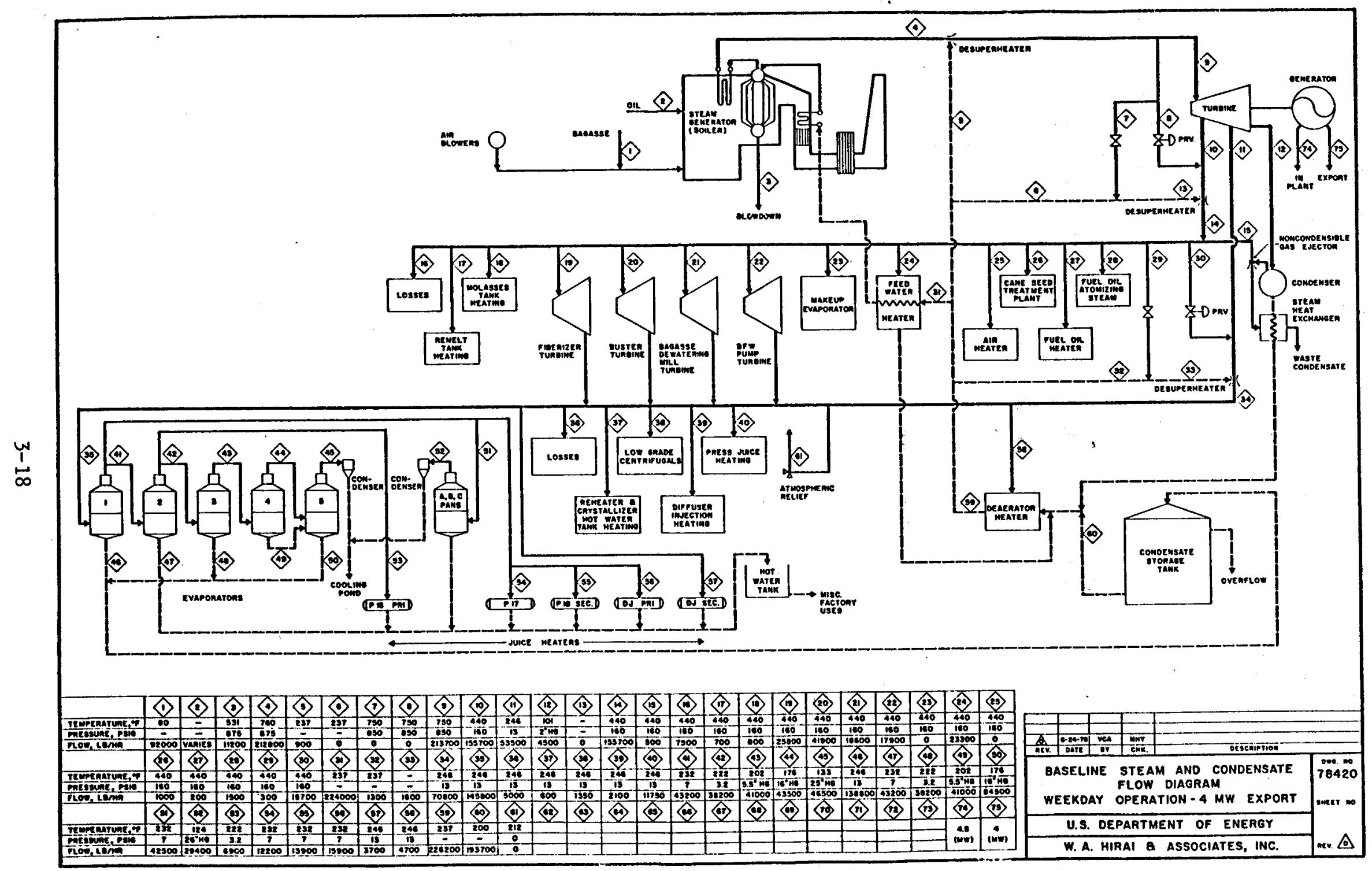

FIGURE $3-5$

BASELINE STEAM AND CONDENSATE

FLOW DIAGRAM

WEEKDAY OPERATION - 4 MW EXPORT 


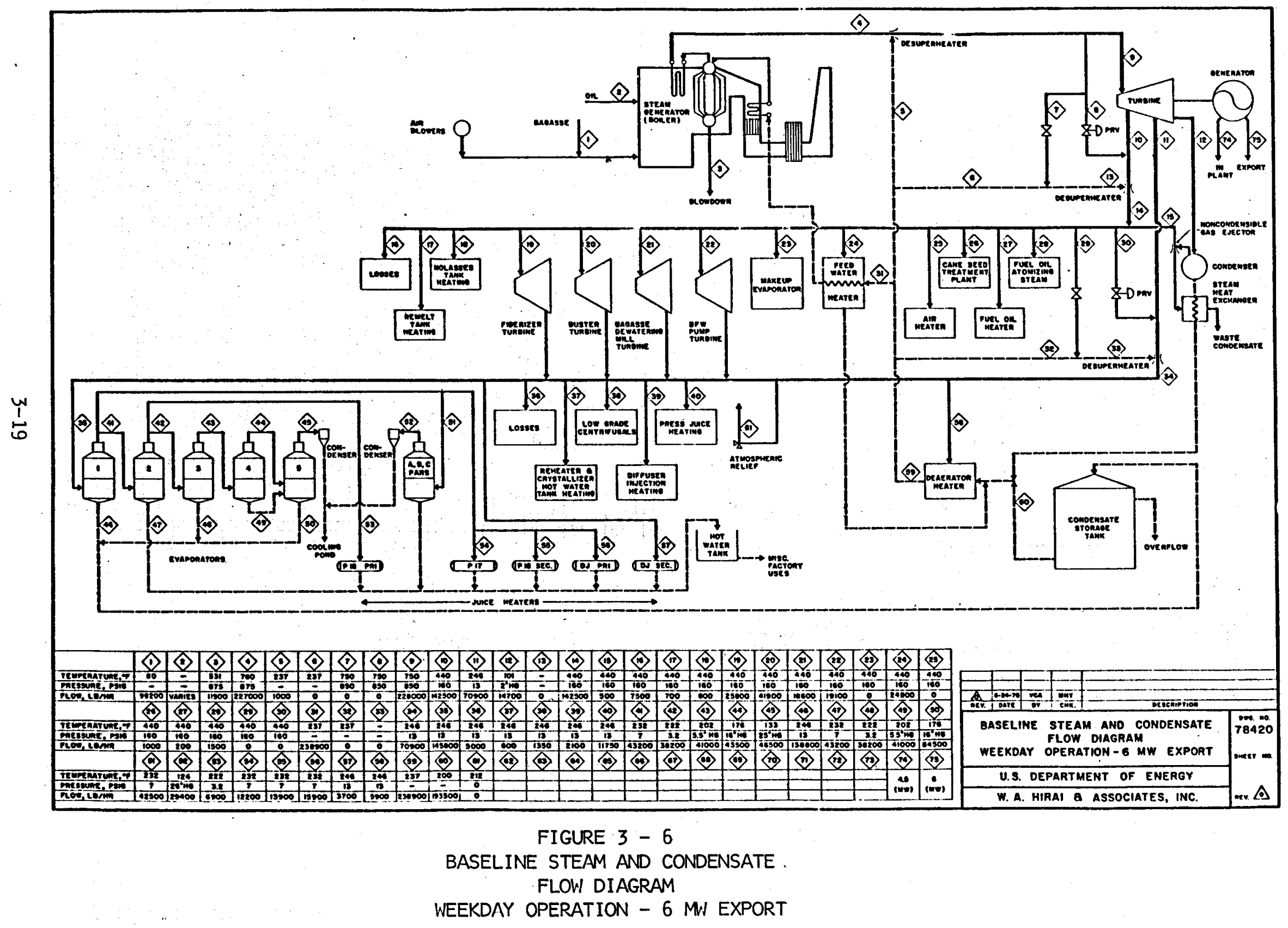




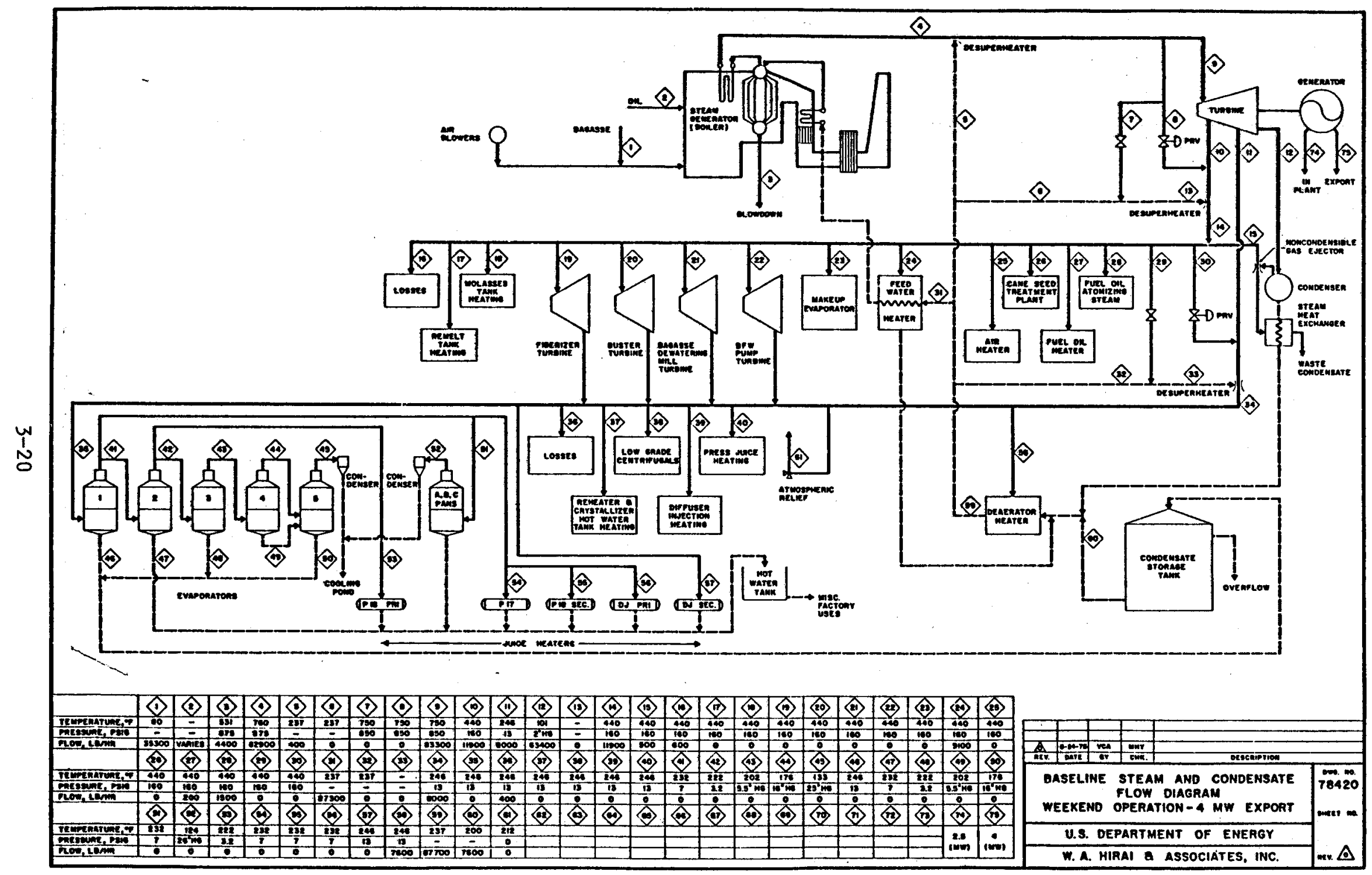

FIGURE $3-7$

BASELINE STEAM AND CONDENSATE

FLOW DIAGRAM

WEEKEND OPERATION - 4 MI EXPORT 


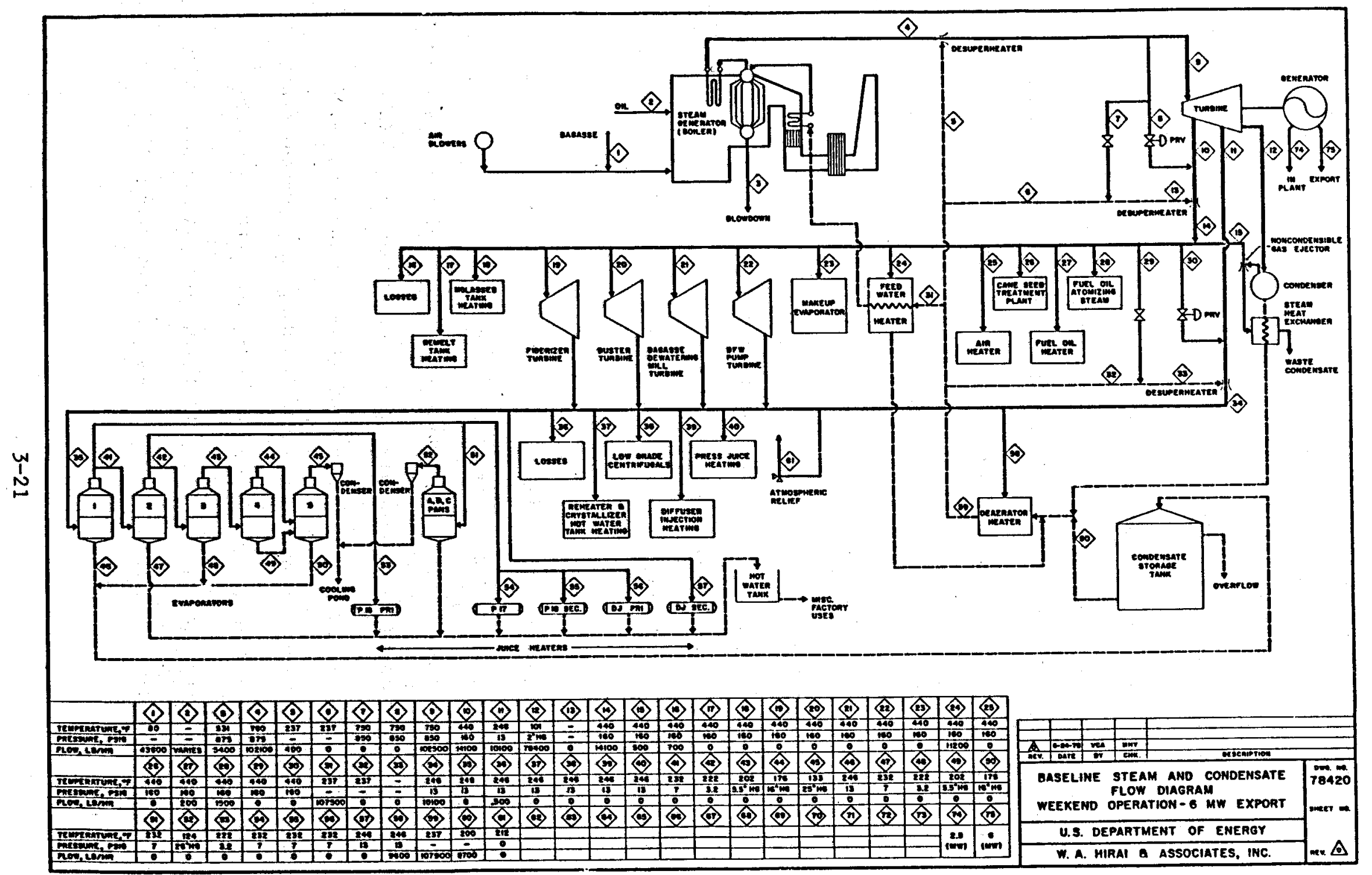

FIGURE $3-8$

BASELINE STEAM AND CONDENSATE

FLOW DIAGRAM

WEEKEND OPERATION - 6 MN EXPORT 
- Turbogenerator Condenser Gas Ejector

- Air Heater

- Remelt Tank Heating

- Cane Seed Treatment Plant

of the demands listed, the turbines do not condense steam but further throttle the supply steam to the exhaust steam demands. Exhaust steam demands for the baseline condition are listed in a similar manner below. By far, the largest steam demand is for the juice evaporators.

- Evaporators

- D J Secondary Heater

- Low Grade Centrifugals

- Deaerator Heater

- Reheater and Crystallizer Hot Water Tank Heating

- Diffuser Injection Heating

- Press Juice Heating

\subsubsection{Condensate Flow}

Condensates return to the boiler from various locations throughout the factory. The largest source of condensates is the juice evaporators where streams from the first, third, fourth, and fifth cells are returned. Other sources of condensate are the turbogenerator condenser and feed water heater. Should the million pound condensate storage tank level run low, the makeup evaporator is activated to supply the turbogenerator condenser with more vapors, and hence more condensate exits the condenser. Condensate tank level normally drops during the weekend when the factory is not operating and excess condensates are not returning from the process equipment. 
A11 condensates returning to the power plant are routed either to the condensate storage tank or directly to the deaerating heater. Excess condensate during the weekdays accumulates in the condensate storage tank, eventually filling the tank and overflowing to the land reclamation project.

Most of the hot water exiting the deaerating heater enters the single feedwater heater with some flows being used for the desuperheaters. Feedwater then passes through the economizer and finally into the boiler drum.

Other condensates in the factory supply the miscellaneous factory demands including process hot water and wash down. The condensates for these purposes are drawn from the second effect evaporator, juice heaters, and the sugar pans. There are no factory hot water requirements during the weekend and therefore hot water does not need to be made up when the factory is not operating.

\subsection{COMPARISON WITH BEET SUGAR PROCESSING}

An evaluation of beet sugar processing reveals that while there are overall similarities between the beet and cane sugar industries, differences also exist. These differences are reflected primarily in the handling and use of the fibrous material. In cane processing, the bagasse is used as a fuel stock whereas beet pulp is processed into cattlefeed.

\subsubsection{Similarities}

Both cane and sugar beet processes use steam for heating and evaporation purposes. Both practice multiple-effect evaporation of juice, vapor bleeding from evaporators for heating, and crystallization in vacuum pans, followed by centrifugal separation of sugar cyrstals from molasses. 


\subsubsection{Dissimilarities}

Raw Material Preparation. The washing and preparation of the beets require significantly less power and equipment than for cane preparation. Beets only require a slicing operation, whereas cane requires a shredding of the tough rind and inner core. In addition, substantial energy and equipment are allocated to cane washing and detrashing. This is peculiar to Hawaij because of the total dependence on mechanized harvesting operations which includes large percentages of dirt and leaves. In magnitude of equipment sizing, the equipment required for preparatory work on beets and cane are of totally different orders, which accounts for most of the electrical energy difference between beet and cane sugar processing.

Clarification. Beet sugar juice processing requires more steps in the clarification process. This involves carbonatation in addition to the sulfitation process. Implicit in carbonatation is additional juice filtering and heating requirements.

Evaporation. Typically, beet sugar evaporation and cane juice evaporation are accomplished in multiple effect evaporators. However the beet industry generally utilizes a higher pressure and temperature steam and as a consequence, does not operate the final effect at low absolute vacuums, when compared to the cane juice evaporators. The higher operating temperatures also increase the flexibility of using effect vapors for various process demands.

The beet industry generally uses first effect steam supply of 40 to 60 psig while the sugar cane evaporators use lower steam pressures, in the order of 10 to $20 \mathrm{psig}$. The evaporators of the two processes are of dissimilar construction and have different design heat rates. Because of the 
lower steam pressure and temperatures, cane sugar evaporators lend themselves more easily to the use of moderate temperature geothermal fluids.

Turbogenerators. Both industries utilize turbogenerators for the in-house production of electrical energy. In the beet industry, this power is normally used entirely within the factory. In the Hawaijan sugar inndustry, the electrical power is used for:

- Factory requirements.

- Cane irrigation water pumping (Puna Sugar is an exception, having unirrigated fields).

- Supply to the local electrical utility for general distribution.

Because of these additional electrical loads, many Hawailan sugar cane factories have automatic extraction-condensing turbogenerators to more fully utilize the steam energy. On the other hand, turbogenerators that exhaust only into the process steam lines predominate in the beet factories.

Final Product. The sugar produced in a beet factory is a refined sugar. Further processing after crystalization, centrifuging, and drying is unnecessary. The cane sugar as produced in the Hawaijan factories is a high grade raw sugar that must be refined separately at the $C \& H$ refinery in Crockett, California.

Fibrous Residue. After the extraction of the juice from the beet, the pulp is pressed and dried. Incorporation of additives produces an acceptable livestock feed that is marketed. Cane residue is dewatered and used as fuel for the steam boilers. The final disposition of the fibrous material in part explains the relative complexity of Puna Sugar's 
steam and electric generation facilities. The prepared cane residue is itself an intermediate product, with the final product being electricity. The added equipment sophistication is used to maximize that electric power production.

\subsection{OTHER POTENTIAL GEOTHERMAL ENERGY USERS IN THE AREA}

Puna Sugar is by far the largest producer and user of energy in the Puna district. Within a one mile radius of the factory, however, several small facilities could conceivably use geothermal energy. The practicalities of using this energy is beyond the scope of this work, but a brief description of these plants is included here.

\subsubsection{Papaya Processing}

Puna Papaya Company, like Puna Sugar, is an operating subsidiary of Amfac, Inc. Fresh papayas at its plant are heat treated and fumigated prior to marketing. Current usage of energy is between 350 and $500 \mathrm{~kW}$ of electricity and further increases are expected with plant expansion. Much of the electric demand is used for heating purposes and design modifications can allow use of low pressure steam.

\subsubsection{Macadamia Nut Processing}

Macadamia nuts from nearly 4,000 acres are husked, cracked and boiled at the Mauna Loa Orchards processing plant. The cracked shells are used as fuel in the company's boiler, producing up to 20,000 pounds of steam per hour. The steam is used primarily for air dryers and process heat exchangers. Of particular interest at this facility is its use of low pressure steam for process plant air conditioning. It is perhaps the most successful application of the absorption air conditioning principle in the State. 
It is rather dubious whether Mauna Loa Orchards would be interested in geothermal steam as its own biomass based fuel leaves them independent of fuel oil supply. However, the plant also consumes an estimated 300 $\mathrm{kW}$, and this area may be profitable to investigate.

\subsubsection{Slaughter House Operations}

A small slaughter house operation is conducted by the Miko Meat Corporation near the Puna Sugar factory. It employs a boiler estimated at $50 \mathrm{HP}$ for washdown and sanitation purposes and also consumes approximately $250 \mathrm{~kW}$ in electricity. Much of the electrical load is for refrigeration and incorporation of an absorption refrigeration cycle may be practical. 


\section{REFERENCES}

3-1 "01aa Sugar Company," Honolulu Star Bulletin, April 1920.

3-2 "Hawaiian Sugar Plantation History," Honolulu Star Bulletin, September 28, 1935.

3-3 "Watt's Record at 0laa, One of Great Expansion," The Honolulu Advertiser, February 18, 1938.

3-4 Hitch, Thomas K., How the Collapse of the Sugar Industry Would Impact on Hawaij's Economy, Research Division, First Hawai ian Bank, June 15, 1978.

3-5 "01aa Plantation Begins Mechanized Harvesting," Honolulu Star Bulletin, Nov. 24, 1953.

3-6 "New Estimate Sets Total at \$3 Million," The Honolulu Advertiser, March 8, 1955.

3-7 Matsuoka, Yoshio, Sugar Cane is Lost to Volcano, Hawaiian Sugar Planters Association, March, 1960.

3-8 "Agreement Ends 7-Year-01d Suit," The Honolulu Advertiser, Sept. 15, 1960.

3-9 "Stockholders of Puna OK Amfac Merger," Honolulu Star Bulletin, Oct. 31, 1968.

3-10 "Ceremonies Slated Today for $\$ 9$ Mi11ion Puna Job," Hawaii TribuneHerald, April 2, 1970.

3-11 Simpich, Fredrick, Jr., Dynasty in the Pacific, New York: MCGraw-Hill Book Co., 1974.

3-12 Meade, George P., Cane Sugar Handbook, 9th ed. New York: John Wiley \& Sons, 1963.

3-13 McKay, C. M., The Gilmore Sugar Manual, Fargo, North Dakota: Sugar Publications, Gilmore Sugar Manual Division, 1975.

3-14 Payne, J. H., Sugar Cane Factory Analytical Control, Revised edition, New York: Elsevier Publishing Co., 1968. 
Section 4

GEOLOGICAL SETTING FOR THE PROJECT

The proposed geothermal energy utilization project is located in the Puna district of the Island of Hawaii. Fortunately, from 1973 to 1977 , the faculty and staff of the University of Hawaij's Hawaii Institute of Geophysics carried out an intense geothermal exploration program in the area of the proposed project. Furthermore, a 6,450 foot deep exploratory well, later to be called HGP-A, discovered a commercial quality geothermal reservoir.

Data from the numerous surveys and well logs have been published, albeit in a variety of formats. Relevant information has been collected, sifted and collated here for an evaluation of the geological and geophysical setting of the project. Since data from the exploration program has been reported in metric units, the metric references will be retained in this section.

This section discusses the geological parameters concerned with the project. It begins with the regional geological setting and progressively narrows the discussion to the limited area of the Puna district where the geothermal production wells are proposed for the project. It concludes with an evaluation of the site selected for this project.

\subsection{REGIONAL GEOLOGY}

The Hawaiian islands are the southeastern terminus of a series of huge 
lava masses that have been built from the Mid-Pacific ocean floor. The chain of islands and seamounts extends from the Island of Hawaii northwesterly to Midway and thereafter northerly, as the Emperor Seamounts,.. to Kamchatka. Current plate tectonic theory relates that these lava masses were all formed by a permanent hotspot, and as the Pacific plate drifts, new island masses are created. The islands of Hawaii are the latest in the continuing series of these island formations. Figure 4-1 is a relief model photograph of the main Hawaiian Ridge.

\subsubsection{Regional Setting .}

The Island of Hawaii is shown in Figure 4-2, roughly triangular in plan view with 150 mile long bases, and rising some 30,000 feet above the average surrounding ocean floor. Its maximum vertical thickness is considerably greater due to downbowing of the sea floor under the island's weight.

Crowning this pile terminus are five shield volcanoes that have grown above sea level. Other volcanic masses may be buried. Radiogenic dating of accessible rocks indicates an age range from about 450,000 years at the island's northwest end to zero at its southeast end.

\subsubsection{Hawaiian Volcanic Structure}

Despite the 1.3:1 vertical exaggeration in Figure $4-1$, the huge lava mass can be appreciated. It indicates some major features of Hawaij's volcanoes and their differences with continental types.

- More striking than height is volume. Where Mt. Shasta and Mt.

Fuji are volcanic masses of about 100 cubic miles, the volumes of individual Hawaijan volcanoes vary from 1000 to 10,000 cubic miles. 
C

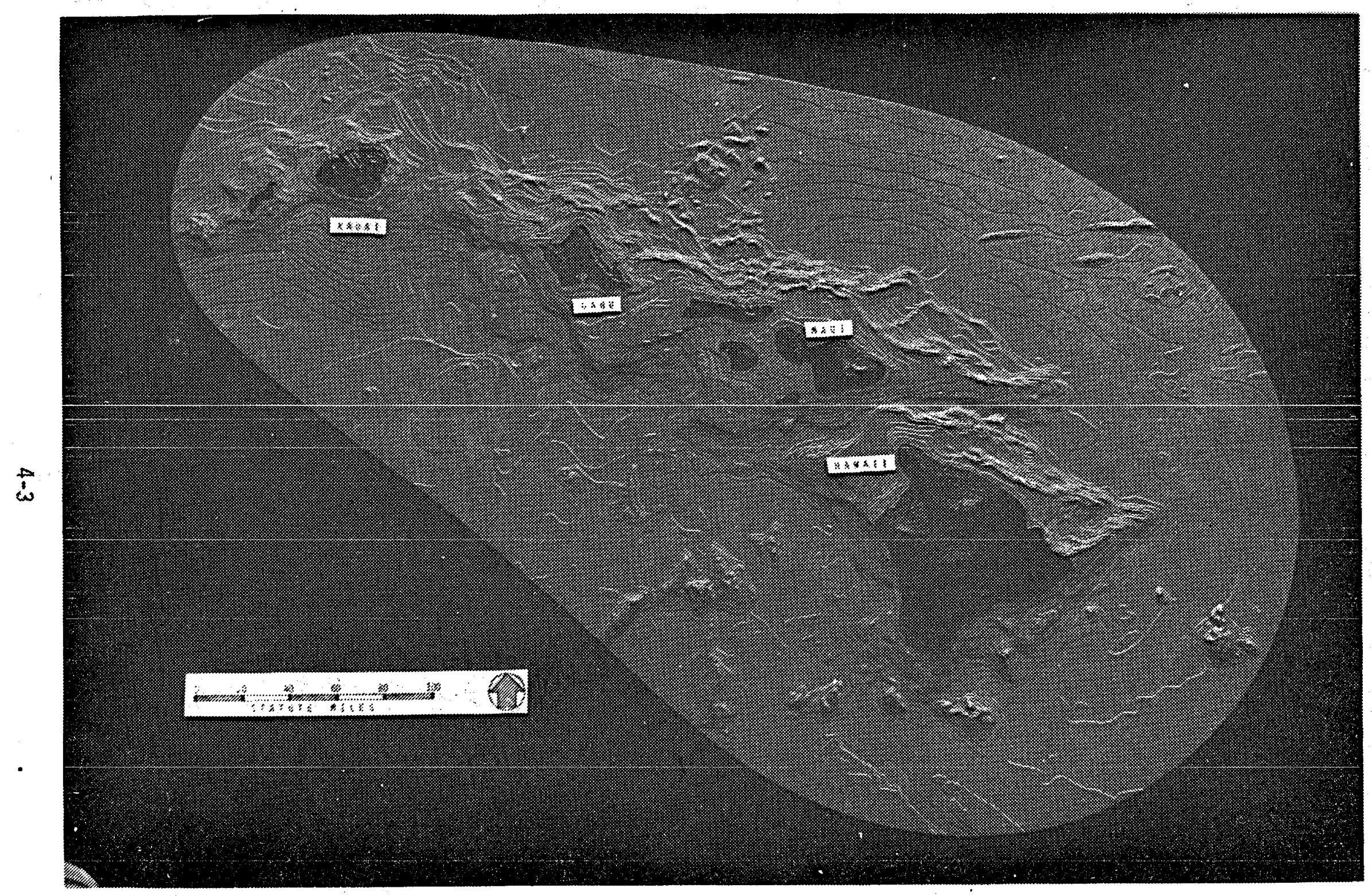

Figure 4-1

Relief Model of the Southwestern Hawaitan Ridge 


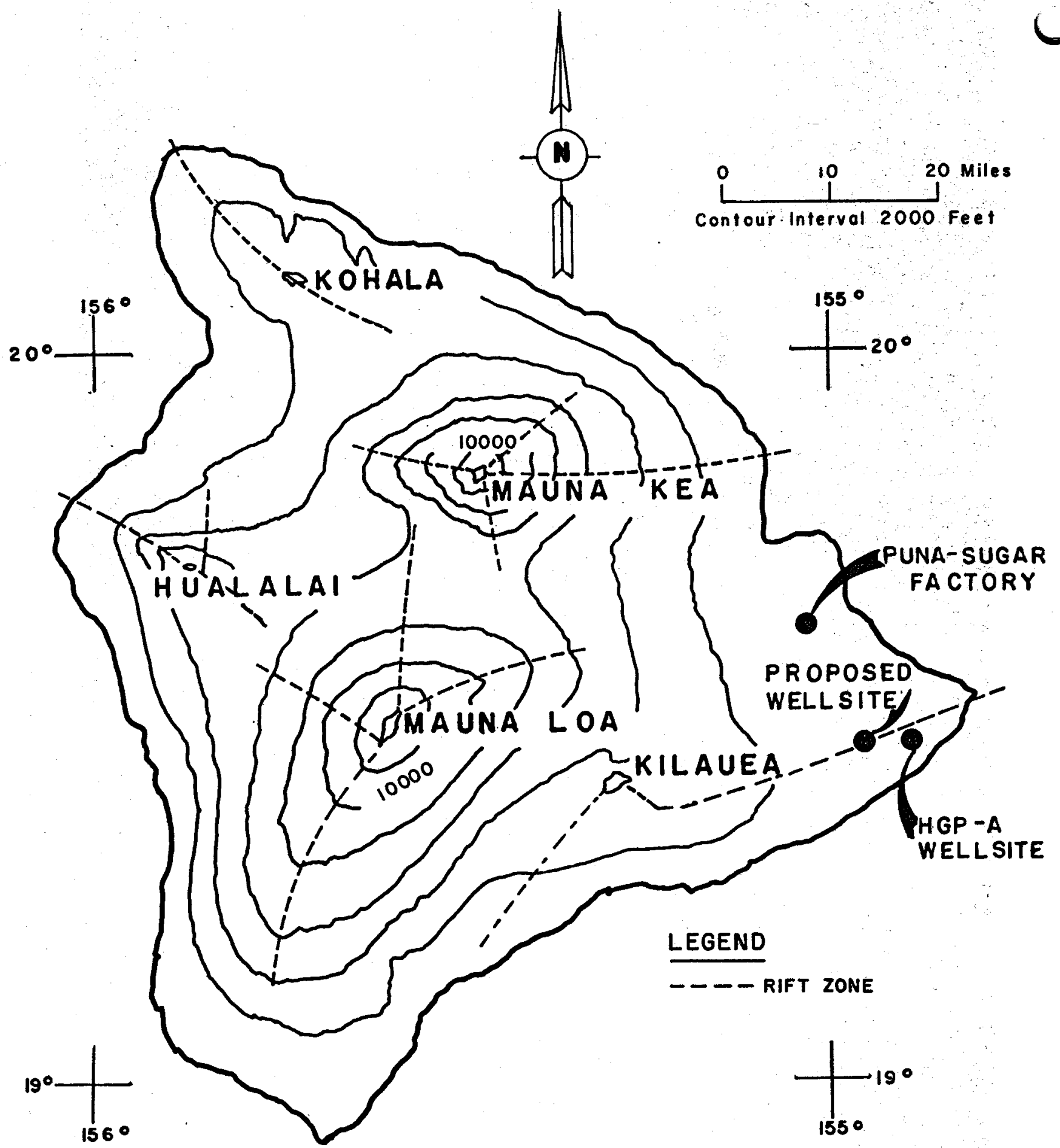

Figure 4-2

Island of Hawaii 
- Most of the typical Hawaiian volcanoes are of extruded and intruded basalt.

- Because of the Hawaiian lava's low viscosity, relatively flat land areas evolve, resulting in the term "shield volcano."

- Rift zones are formed along one or more lateral extension systems radiating from the central volcanic magma conduit.

Five volcanoes, Kohala, Mauna Kea, Hualalai, Mauna Loa and Kilauea, coalesce to form the Island of Hawaij. Of these five, the latter three have added to the island within historic times, which dates back to 1778. The most recent eruption of Hualalai occurred in the period 1801-1802, but both Mauna Loa and Kilauea have been among the most active volcanoes in the world during the last two centuries. Mauna Loa erupted last in 1975, and Kilauea has broken out repeatedly since 1952, being in eruption almost continuously since 1964.

Both Mauna Loa and Kilauea are indented by summit calderas whose floors are as much as $180 \mathrm{~m}$ (600 ft.) below the rims. The calderas were somewhat deeper but have been partly filled by lava flows.

Extending outward from the calderas are rift zones, areas of innumerable open or filled fissures, that have served as pathways for the rise of magma that produced most of the eruptions. Mauna Loa and Kilauea each have two major rift zones. At the surface, the rift zones are marked not only by fissures, but also by many spatter cones, ramparts and cinder cones built at the site of eruptions and by a few pit craters. Rift zones exposed by erosion on older Hawaijan volcanoes contain thousands of dikes formed by consolidation of the magma in fissures. Individual dikes may reach $15 \mathrm{~m}$ (45 ft.) in thickness but most of them are less than $2 \mathrm{~m}(6 \mathrm{ft}$.). Trans- 
ects of dissected rifts typically give several hundred dikes per kilometer and more than 350 per kilometer is not uncommon. The attitude of dikes vary considerably but most of them strike more or less parallel to the rift zone trend and dip in one of the other directions at angles greater than $70^{0}$ to the horizontal.

From intense studies on Kilauea volcano over the decades, a coherent picture of its magmatic process can be proposed. Earthquake data reveals that magma originates at a depth of $60 \mathrm{~km}(40 \mathrm{mi}$.$) and travels upward$ through nearly vertical conduits to enter a reservoir under the summit area. Although different values have been given as to the size of the reservoir, the average configuration is a vertical cylinder roughly $5 \mathrm{~km}$ (3 mi.) below the ground surface. From this reservoir, magma sometimes ascends to erupt through the Kilauea crater proper, and other times intrudes laterally into subterranean passageways, migrating along the rift zones.

The mode of magma excursion through a rift zone is forceful intrusion into subterranean vertical cracks which are initiated by gravitational slumping of the volcano's flank. The injected magma pressures the cracks to widen and extend, allowing the magma to intrude further. By this progressive action, the magma excursion was tracked from the Kilauea summit area down the East Rift by earthquake monitoring and ground deformation measurements during the eruption of 1959-1960.

A simplified conceptual diagram of magma movement from its source to eruption through the summit or through the rift zones is shown in Figure 4-3. 


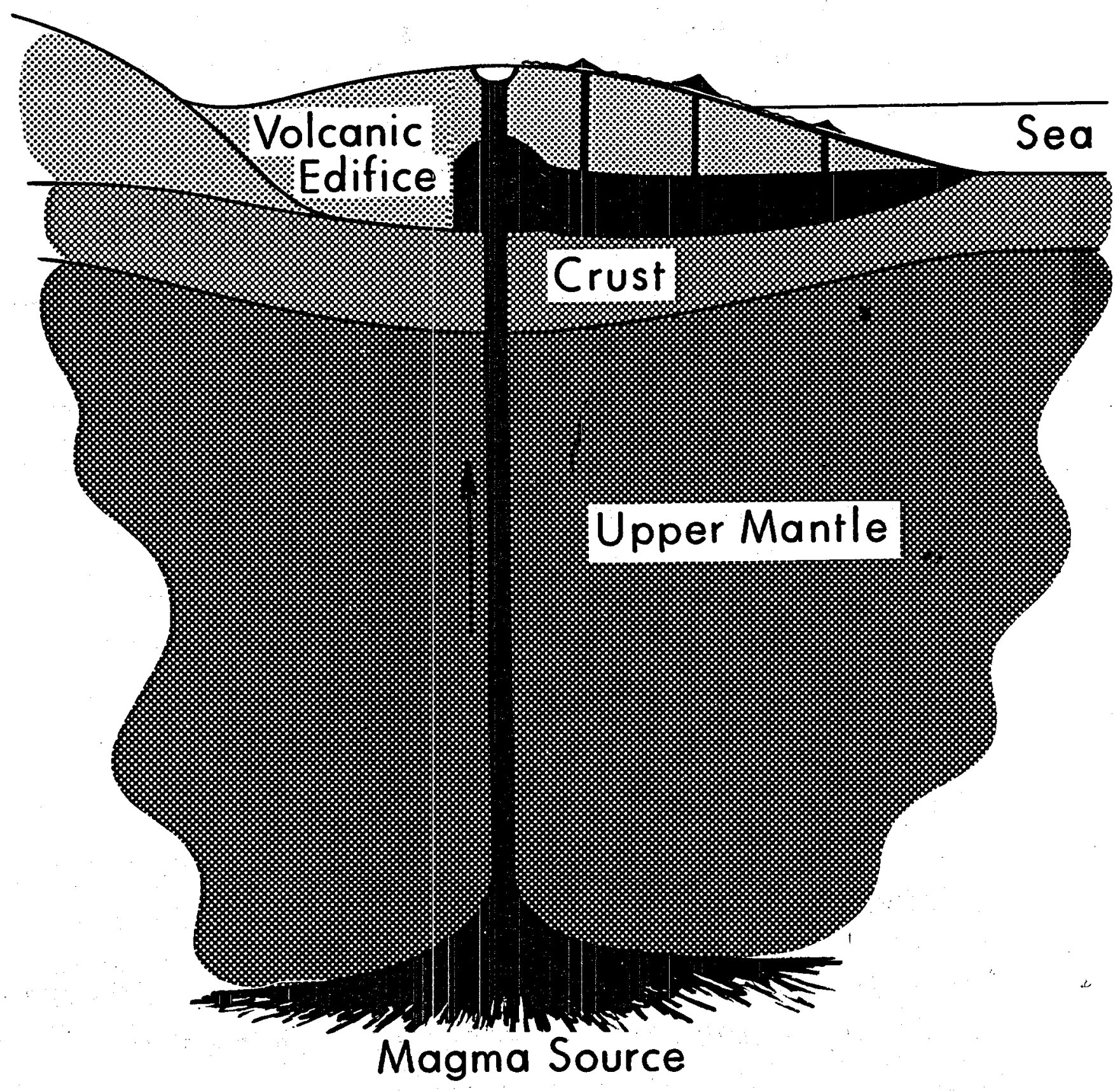

Figure 4-3

Conceptual Diagram of Kilauea Volcano's Magmatic Process 


\subsection{THE EAST RIFT ZONE OF KILAUEA VOLCANO}

Following the theory of Hawaijan volcanic origin, it is obvious that thermal energy is concentrated in the summit and rift zone areas of volcanoes. Logically, these were the first areas to be investigated for geothermal resources.

\subsubsection{The Exploration Program}

The exploration program which began in 1973, was carried out by the Hawaij Institute of Geophysics through funding by federal, state and county agencies. The summit areas were exluded from exploration because they were either in national parks, or because they were inaccessible even for the hardy hiker. Exploration was therefore limited to the rift zones of Hualalai, Mauna Loa and Kilauea.

Reconnaisance surveys, which included infrared scanning, dipole-dipole electrical and micro-earthquake surveys, initially showed the East Rift Zone of Kilauea Volcano to be the most promising prospect for geothermal resources. Following the reconnaisance phase, all subsequent efforts concentrated on the East Rift Zone. Detailed narratives of the exploration program have been published and only a brief summary will be presented in the following paragraphs.

A systematic survey of published literature and known geology did not prove too fruitful. Geothermal exploration in a basaltic province similar to Hawaii had not been done elsewhere and even the experience of the Icelandic geothermal program was not helpful for two reasons. Icelandic geothermal literature was not abundant in 1973 and the island is a case of spreading zone volcanism, while Hawaii has intraplate volcanism. In the absence of 
referable past experience, various types of affordable geophysical surveys were tried.

Approximately a dozen different survey methods were initiated and these can be classified by the kind of information they yielded. The gravity, magnetic and active seismic surveys contributed to the delineation of the subsurface geological structure of the East Rift.. In particular, they outlined a dense body at $2.3 \mathrm{~km}(1.4 \mathrm{mi}$.$) depth with a width of 12$ to $17 \mathrm{~km}(7.4$ to 10.5 mi.). This was identified as a dike complex made up of magma residues from past eruptions. It was recognized as a depositary of remnant thermal energy, and hence, the energy source for the hydrothermal processes on the East Rift. Passive seismic surveys and electrical surveys, which included dipoledipole, loop-to-loop, and line-to-loop methods, pointed to areas where hydrothermal activity is most intense. Temperature surveys of existing wells and geochemical surveys also helped in suggesting areas of hot water. After the HGP-A exploratory hole found a geothermal reservoir, a re-examination of the data from microearthquake surveys outlined what could be the dimensions of that reservoir.

The exploration program narrowed the choice of possible drilling sites to two locations, Site $A$ and Site $B$, which are shown in Figure 4-4. Geophysical indicators that favored Site A were data from the well temperature, geochemical surveys, and self potential surveys. The indicators that favored Site B were data from the well temperature, self potential, electrical resistivity, and magnetic surveys. In the end, the availability of land was the deciding factor that induced the site selection committee to choose Site A.

The exploratory HGP-A hole was drilled to a depth of 6450 feet with a pro- 


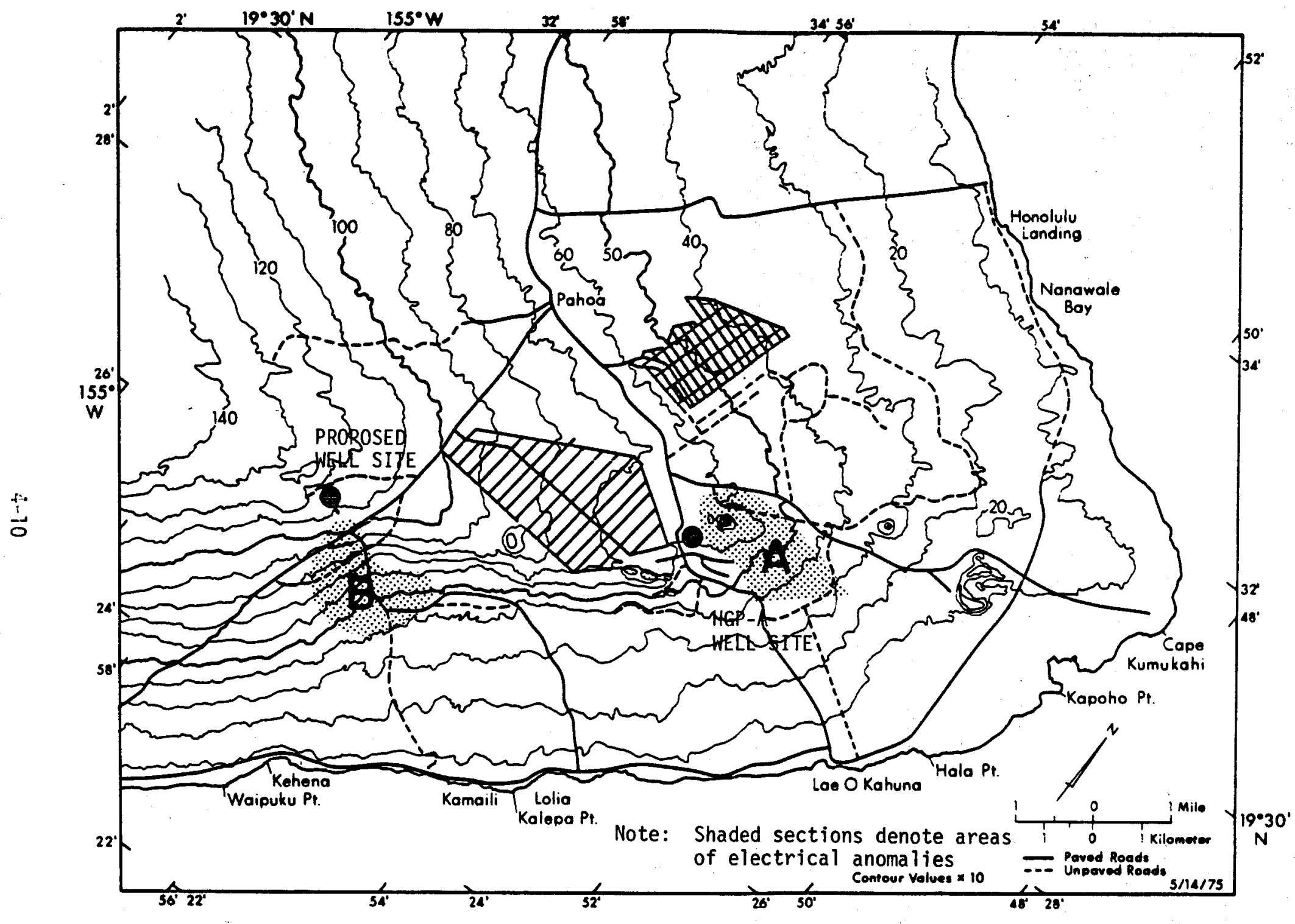

Figure 4-4

Areas of Electrical Anomalies

Adapted from Klein and Kauahikaua, 1975 
duction bore diameter of $8-1 / 2$ inches. Several months after the completion of the hole, steam was flashed. The base temperature of the newly found reservoir is approximately $300^{\circ} \mathrm{C}\left(572^{\circ} \mathrm{F}\right)$. The 1 ithological logs and core samples from the well were extremely helpful in interpreting the results of the surface geophysical surveys. Even after the completion of the well, active and passive seismic experiments were conducted to round out knowledge of the area surrounding the well.

By piecing together the results of the various surveys and the logs from the well, a rather consistent model of the geological structure and thermal process of the East Rift has emerged. In the following subsections, the discussions will include the geology of the East Rift, its subsurface structure and thermal process, and the characteristics of the geothermal reservoir. Finally, the section shall conclude with an evaluation of the area selected as the drill site for this project.

\subsubsection{Geology of the East Rift Zone}

As the geology of the Puna District, which includes the East Rift Zone as its most prominent feature, was succinctly and adequately compiled by Macdonald (1977), his report will be reproduced verbatim. However, as the report was written prior to drilling the HGP-A well; it does not contain the wealth of information the well provided. A short addendum providing supplemental well information follows Macdonald's report. For geographical names, Figure 4-5 should be consulted.

The East Rift Zone extends southeastward from the Kilauea caldera for about six $\mathrm{km}$, then bends abruptly east-northeastward and extends through Cape Kumukahi, the eastern point of the island. Beyond the cape it forms a broad east-northeasttending ridge on the ocean floor for another $65 \mathrm{~km}$ (Malahoff 


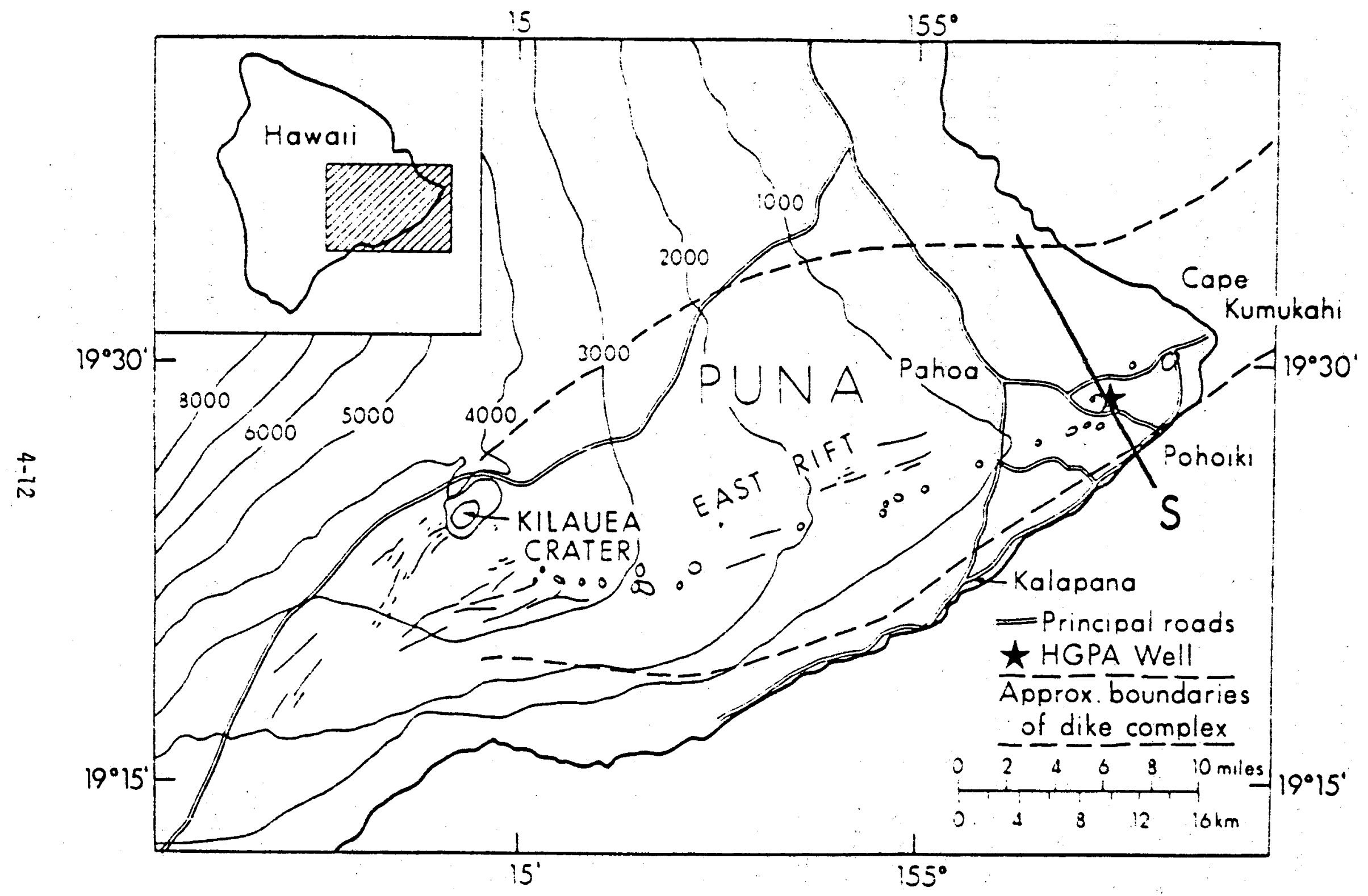

Figure 4-5

Geographical Names in the Puna Distrint 
and McCoy, 1967). Northwest of the bend the rift zone is marked by a row of pit craters (the Chain of Craters) and a few spatter-and-cinder cones. East-northeast of the bend more than 60 spatter and cinder cones mark the sites of prehistoric, but geologically recent, eruptions along the rift zone. Just before the beginning of written history, eruptions took place on the eastern part of the rift zone in about 1750 and 1790. Historic eruptions along it have occurred in $1840,1922,1923,1955,1960,1961,1962,1963$, 1965, 1968, and 1969 to the present.

The area known as East Puna consists of the part of the Kilauea volcano east of about $155^{\circ} \mathrm{W}$ latitude. It is a broad, gently sloping ridge built by lava flows from the East Rift Zone, and the rift zone extends along its crest. It is situated more or less midway between Kilauea caldera and the termination of the rift zone ridge at the ocean floor. Within it, between the $500 \mathrm{~m}$ contour and sea level, eruptions have occurred in about 1750 and 1790, and in 1840, 1955, and 1960. In 1924, numerous earthquakes and volcanic tremors accompanied the disappearance of lava lake in Kilauea caldera and the sinking of the floor of a graben along the rift zone close to sea level in East Puna; although no molten lava appeared at the surface above sea level, it is virtually certain that a large volume of magma moved eastward through the rift zone. The surface expression of the rift zone is about $3 \mathrm{~km}$ wide. East of Cape Kamukahi the submarine cones along the rift zone appear very fresh in photographs. A submarine eruption occurred 
a few kilometers off shore in 1884 .

Lava flows from vents along the rift zone have poured downslope, building a broad structural arch that plunges east-northeastward at an angle of $1^{\circ}$ to $2^{\circ}$. North of the rift zone the lava beds dip $2^{0}$ to $4^{0}$ northeastward. Locally on the south side of the ridge, dips of more than $6^{\circ}$ probably are the result of lava flows mantling a southeast-facing fault scarp (Stearns and Macdonald, 1946, plate 1). The lava flows are both pahoehoe and aa types. No specific determinations of permeability are available, but similar lavas yield water freely to wells, and overall permeability is unquestionably high. Large amounts of groundwater move through the area, producing many brackish basal springs along the shoreline.

Beneath sea level, divers have observed what appear to be pillow lavas, and similar lavas are shown in deeper water by photographs (Moore and Fiske, 1969).

Warm $\left(33^{\circ} \mathrm{C}\right)$ brackish water issues in the beach at Pohoiki, $7.6 \mathrm{~km}$ south-southwest of Cape Kumukahi. Previous to 1960, warm $\left(29^{\circ} \mathrm{C}, 84^{\circ} \mathrm{F}\right)$ brackish basal water was present in a crack on the rift zone $2.4 \mathrm{~km}(1.5 \mathrm{mi})$ west of the Cape, and similar water at $32^{\circ} \mathrm{C}\left(90^{\circ} \mathrm{F}\right)$ was present in another crack $1 \mathrm{~km}(0.6$ mi) to the northwest. The cracks lay close to the borders of a graben that sank in 1924; both were buried by lava in 1960 . A well $6 \mathrm{~km}$ (3.6 mi) west of Cape Kumukahi contained brackish water at $34^{\circ} \mathrm{C}\left(93^{\circ} \mathrm{F}\right)$. A well $4 \mathrm{~km}(2.4 \mathrm{mi}) \mathrm{S} 80^{\circ} \mathrm{W}$ of 
Pohoiki contains brackish water at $53^{\circ} \mathrm{C}\left(127^{\circ} \mathrm{F}\right)$. Many steaming vents are present along the rift zone west of $300 \mathrm{~m}$ (984 ft) altitude, but east of that altitude only minor wisps of steam issue, especially in Pawai crater, a small pit crater $10 \mathrm{~km}(6 \mathrm{mi})$ southwest of Cape Kumukahi. At Pahoa, and $8 \mathrm{~km}(4.8 \mathrm{mi})$ to the south along the PahoaKalapana road, wells produce cold basal water of good quality.

The warm-water wells are distinctly more saline than would be expected (Macdonald 1973) on the basis of normal Hawaiian basalt groundwater conditions in other areas of similarly high rainfall and rocks of approximately the same permability. The well nearly west of Pohoiki had, on completion, a chloride content of $6500 \mathrm{mg} / 1$ (approximately $6000 \mathrm{ppm}$ ), and the well $6 \mathrm{~km}$ (3.6 mi) west of Cape Kumukahi had a chloride content of 320 ppm. Thus there are distinct anomalies in groundwater conditions in East Puna, and the most probable cause is heating of the sea water saturating the underlying rocks, probably hot intrusive masses along the rift zone, decreasing the density of the water to the point where it can no longer support the normal Ghyben-Herzberg lens of fresh water.

It is remarkable what inferences can be drawn from strictly surface geological data as shown in the above quotation, but core samples and logs from a single well can add immensely to the fund of cumulative knowledge. The rock column down the HGP-A well can be divided into four sections:

- Shallow layers from the ground surface to the transition zone of subaerial to submarine lavas. 
- A transition zone.

- Submarine flow layers with fractures filled by secondary minerals.

- A section characterized by hydrothermal alteration.

The first $500 \mathrm{~m}(1640 \mathrm{ft})$ of the column consists of the familiar basalt lava, pahoehoe flows alternating with aa clinker and cinder. The lavas have high vesicularity and porosity and between any two consecutive flows there is some open space: Overall permeability of this rock section is extremely high. Flow units average $3 \mathrm{~m}(10 \mathrm{ft})$ in thickness and the geology described by Macdonald applies to this section of the rock column.

At $500 \mathrm{~m}(1640 \mathrm{ft})$ depth from ground surface and $300 \mathrm{~m}(1000 \mathrm{ft})$ below sea level there is a transition from subaerial lava to submarine lava. The highly vesicular lava gives way to pillow lava in stages. There is also glassy cinder, which is normally produced in violent contact of hot lava with seawater at the shoreline. From the presence of the transition zone at this depth, it is judged that the island mass in the Puna District has subsided $300 \mathrm{~m}(1000 \mathrm{ft}$.$) .$

Below the transition zone flow units of pillow lavas average $20 \mathrm{~m}(65 \mathrm{ft})$ in thickness. The permeability is lower than the subaerial lavas and decreases with depth. Permeability is no longer due to vesicles and space between flows, but is due to numerous fractures of the rock. From a depth of $750 \mathrm{~m}$ to $1200 \mathrm{~m}$ (2460 ft to $3940 \mathrm{ft}$ ) secondary minerals such as zeolites and calcites fill these fractures so that the bulk permeability is very low. From $1200 \mathrm{~m}$ to $1500 \mathrm{~m}$ (3940 to $4920 \mathrm{ft}$ ) the fractures are open. Whole rock alterations due to hydrothermal action characterize the section from $1200 \mathrm{~m}$ to the bottom of the hole at $1960 \mathrm{~m}(6450 \mathrm{ft})$. 
Fractures in the altered section are partially filled with secondary minerals.

In summary, the rock column from 750 to $1200 \mathrm{~m}$ (2460 to $3940 \mathrm{ft}$ ) is practically impermeable due to secondary mineralization while in the section from $1500 \mathrm{~m}$ to $1960 \mathrm{~m}(4920 \mathrm{ft}$ to $6450 \mathrm{ft}$ ) there is evidence of rocks being subjected to throughgoing alteration. From this arrangement it is obvious that a self-sealing process is at work. In such a process hot water at depth dissolves some minerals which are then carried as solute by the convecting hot water to higher strata. Because the higher strata are cooler, the solutes precipitate as secondary minerals such as zeolites and calcites. These precipitates are deposited by the hot water which is circulating through the rock fractures. Eventually the fractures become clogged and the rock section becomes impermeable. The impermeable section then acts as a seal, or caprock, to trap the hot water below. By this self-sealing process, a confined Hawaijan geothermal reservoir is formed.

The fractures and cracks throughout the rock column are produced by tensional earthquakes in the region. Focal mechanism solutions of earthquakes in the region plainly point to tensional patterns, with the tensional axes horizontal in the north-south direction. The origin of these stresses resides in the enlargement of the dikes at depth due to forceful intrusion of magma.

\subsubsection{The Subsurface Structure of the East Rift Zone}

Combining the contributions from seismic refraction and gravity surveys produces a velocity-depth profile in the section traversing the East Rift through the geothermal reservoir as shown in Figure 4-6. The significance 


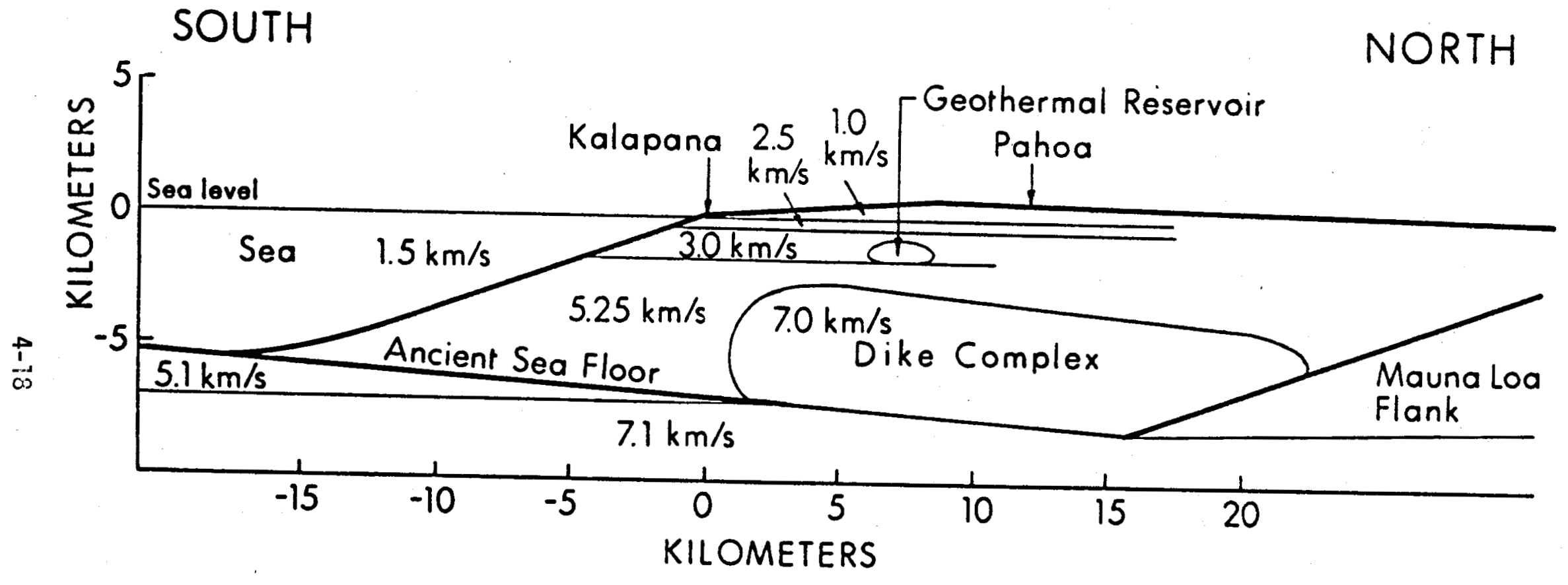

Figure 4-6

Velocity-Depth Profile of an East Rift Zone Section Traverse 
of this profile is the correspondence of various velocity values to geological features.

The shallowest layer has an average $P$-wave velocity in the range of 1.0 $\mathrm{km} / \mathrm{sec}(3300 \mathrm{ft} / \mathrm{sec})$. Such a low value, commonly observed for surficial layers, may seem strange for basalt lava, but surficial layers have more air space than rock. The transition from $1.0 \mathrm{~km} / \mathrm{sec}$ to $2.5 \mathrm{~km} / \mathrm{sec}(3300$ $\mathrm{ft} / \mathrm{sec}$ to $8200 \mathrm{ft} / \mathrm{sec}$ ) coincides with the water table, which is at sea leve1. The interface between the $2.5 \mathrm{~km} / \mathrm{sec}(8200 \mathrm{ft} / \mathrm{sec})$ and $3.0 \mathrm{~km} / \mathrm{sec}$ (9880 ft/sec) layers occurs at $300 \mathrm{~m}(1000 \mathrm{ft})$ below sea level, the depth of transition from subaerial to submarine lavas.

The core samples from HGP-A do not shed any light on the difference between the $3.0 \mathrm{~km} / \mathrm{sec}(9800 \mathrm{ft} / \mathrm{sec})$ layer and the $5.25 \mathrm{~km} / \mathrm{sec}(17000 \mathrm{ft} / \mathrm{sec}) 1$ ayer because the hole bottoms out just where the interface might be predicted. On the other hand, the electrical resistivity survey shows an infinite resistivity below the plane where the interface should be. From the electrical results, the $5.25 \mathrm{~km} / \mathrm{sec}(17000 \mathrm{ft} / \mathrm{sec})$ layer can be interpreted as containing no hydrothermal fluid and this in turn means that fractures are absent. If a fracture should open up in this layer by an earthquake, it becomes closed in a rather short time due to rock yield at high temperature.

The body with the $7.0 \mathrm{~km} / \mathrm{sec}(23000 \mathrm{ft} / \mathrm{sec})$ velocity, which occurs at $2.3 \mathrm{~km}$ depth (1.4 mi), has been interpreted as an aggregate of closely spaced dikes, so tightly packed as to form a complex, which geophysical probes grossly identify as a homogeneous solid body. The dike complex narrows in width from $17 \mathrm{~km}$ on the west to $12 \mathrm{~km}$ on the eastern side $(10 \mathrm{mi}$ to $7 \mathrm{mi})$ as outlined in Figure 4-5. The dikes in the complex are the passageways through which magma from many past eruptions has worked its way down the rift zone. 


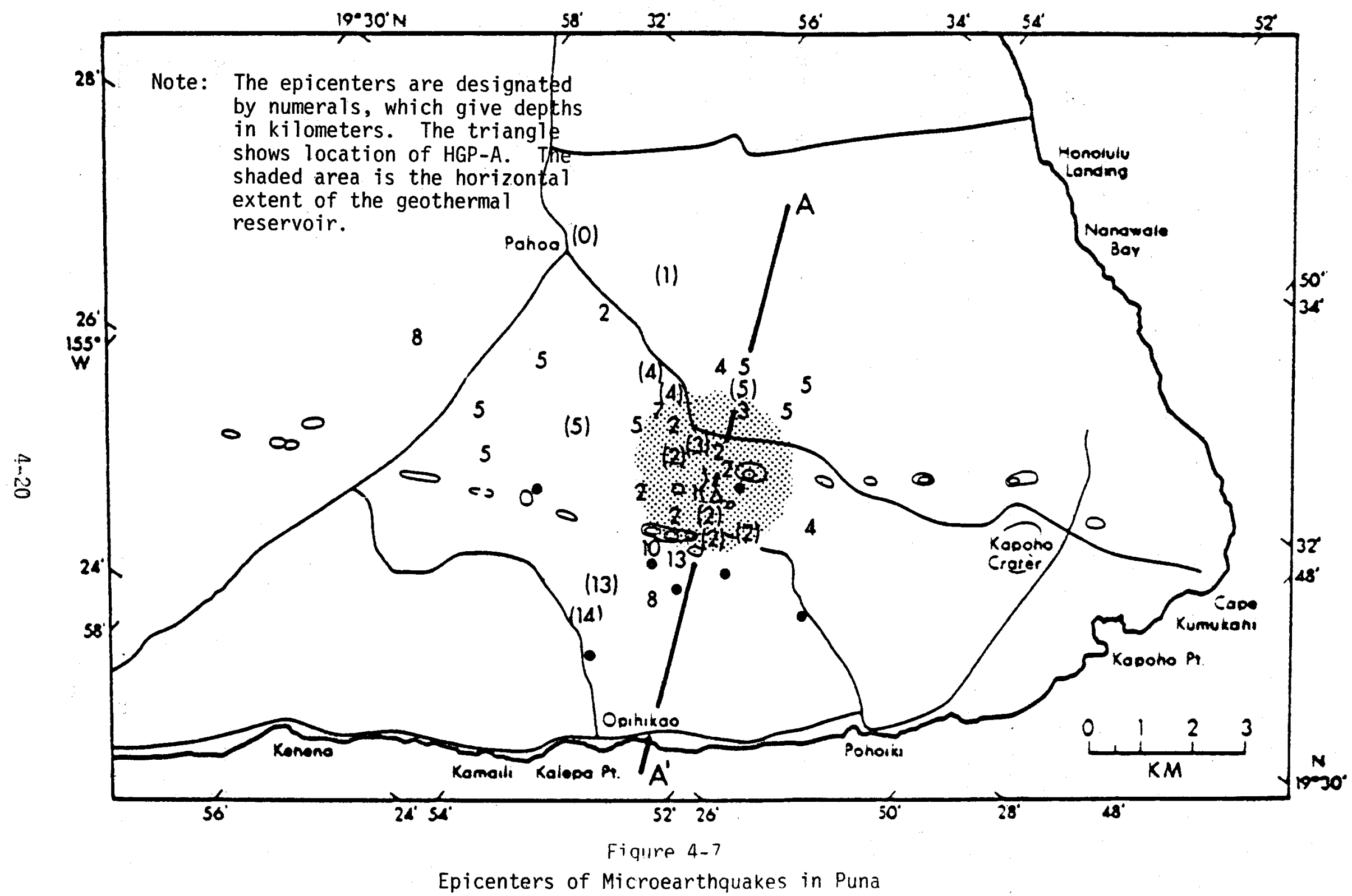

From Suyenaga and Furumoto, 1979 


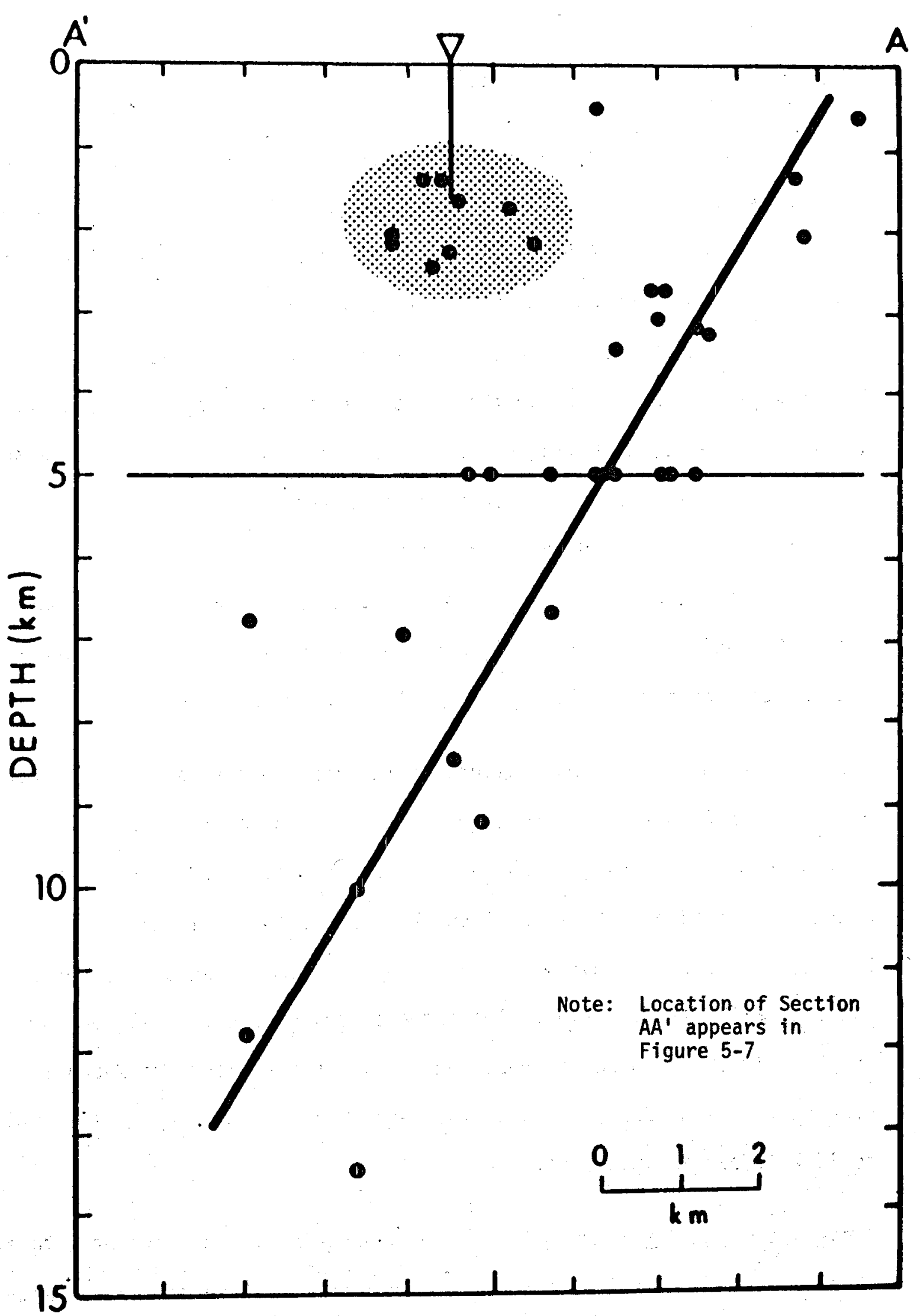

Figure 4-8

Projection of Earthquake Foci Onto Vertical Plan

From Suyenaga and Furumoto, 1979 
Residues from the magma remain trapped in the interstices.

A hindsight examination of microearthquakes data after the completion of HGP-A came across a cluster of earthquakes around the well site as shown in Figures 4-7 and 4-8. From the interpretation that these earthquakes are the result of groundwater coming into contact with hot rocks, it is inferred that the earthquakes outlined the shape and size of the geothermal reservoir. The size of the reservoir can then be taken as $3 \mathrm{~km} \times 2 \mathrm{~km} \times 1.5 \mathrm{~km}(1.8 \mathrm{mi}$ $\times 1.2 \mathrm{mi} \times 0.9 \mathrm{mi})$ with its center at a depth of $1.7 \mathrm{~km}(1 \mathrm{mi})$ below sea level. This puts the greater part of the reservoir in the $3.0 \mathrm{~km} / \mathrm{sec}$ (9800 ft. sec) layer. Because of the ambiguity of hypocentral determination of earthquakes, seismic data should not be given too much weight, but the "infinite resistivity" of the $5.25 \mathrm{~km} / \mathrm{sec}(17000 \mathrm{ft} / \mathrm{sec})$ layer argues for placing the reservoir entirely within the $3.0 \mathrm{~km} / \mathrm{sec}$ layer.

Perspective cutaway representations of the East Puna subsurface structure are shown in Figure 4-9. The underlying formation of the area is the pervasive oceanic crust, probably of Cretaceous age. On this crust, both Mauna Loa and Kilauea have built up their respective volcanic piles. Mauna Loa, being older, had built up a flank by the time Kilauea began extending its East Rift into the area. The magma conduits from the Kilauea summit rest partly on the oceanic crust and partly on the flanks of Mauna Loa. Because of the gradual growth of the East Rift, the dike complex is now 12 to $17 \mathrm{~km}$ broad in this area.

Above the major dike complex sits a smaller chimney-like dike structure, which was detected by surface magnetic surveys. The geothermal reservoir associated with HGP-A is located above the major dike complex and just east of the chimney-like structure. 


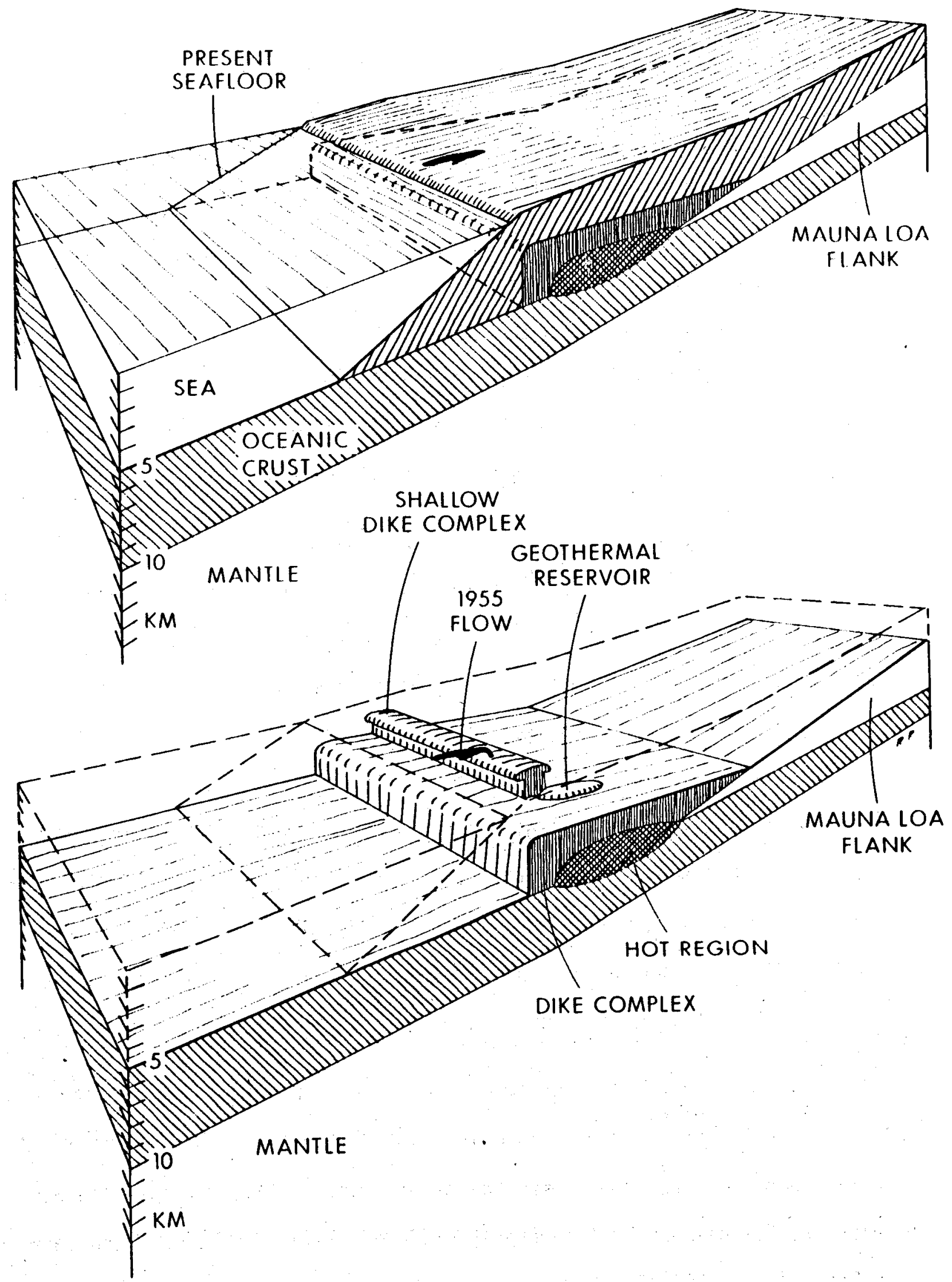

Figure 4-9

Cutaway Perspectives of the Subsurface Structure of the East Rift 
The major dike complex and the smaller structure are mantled by extrusives. As mentioned earlier, the character of the extrusives changes with depth and vesicularity notably decreases. The geothermal reservoir is found entirely in that section of extrusive rocks. However there is evidence from the rock samples of the HGP-A well that solitary dikes also penetrate the geothermal reservoir.

\subsubsection{The Thermal Process of the East Rift Zone}

Once the subsurface geological structure of the East Rift has been compiled, $i$ ts thermal process can be inferred with confidence.

Starting with the theory of forceful magma injection into the rift zone from the summit chamber, it can be reasoned that magma will work its way gradually down the rift zone. Depending upon the amount injected, the magma can travel very far through subterranean passageways, sometimes to the end of the rift zone under the sea, $160 \mathrm{~km}(100 \mathrm{mi})$ from the summit. The passageways are nearly vertical dikes in the dike complex as mentioned in the previous section. Over past geological ages different passageways were taken, but in general the passageways tended to migrate southward. At the present time, the dike complex is about $20 \mathrm{~km}$ wide in some sections of Figure 4-5.

Because of the low thermal conductivity of basaltic rocks, the residual heat from the magma keeps the dike complex hot. Extrapolation of the temperature profile from HGP-A gives an estimated temperature of $1000^{\circ} \mathrm{C}\left(1800^{\circ} \mathrm{F}\right)$ at about $4 \mathrm{~km}$ (2.4 mi) below sea level as depicted in Figure 4-10. The dike complex provides the heat source for the observed thermal and hydrothermal processes on the rift zone. 


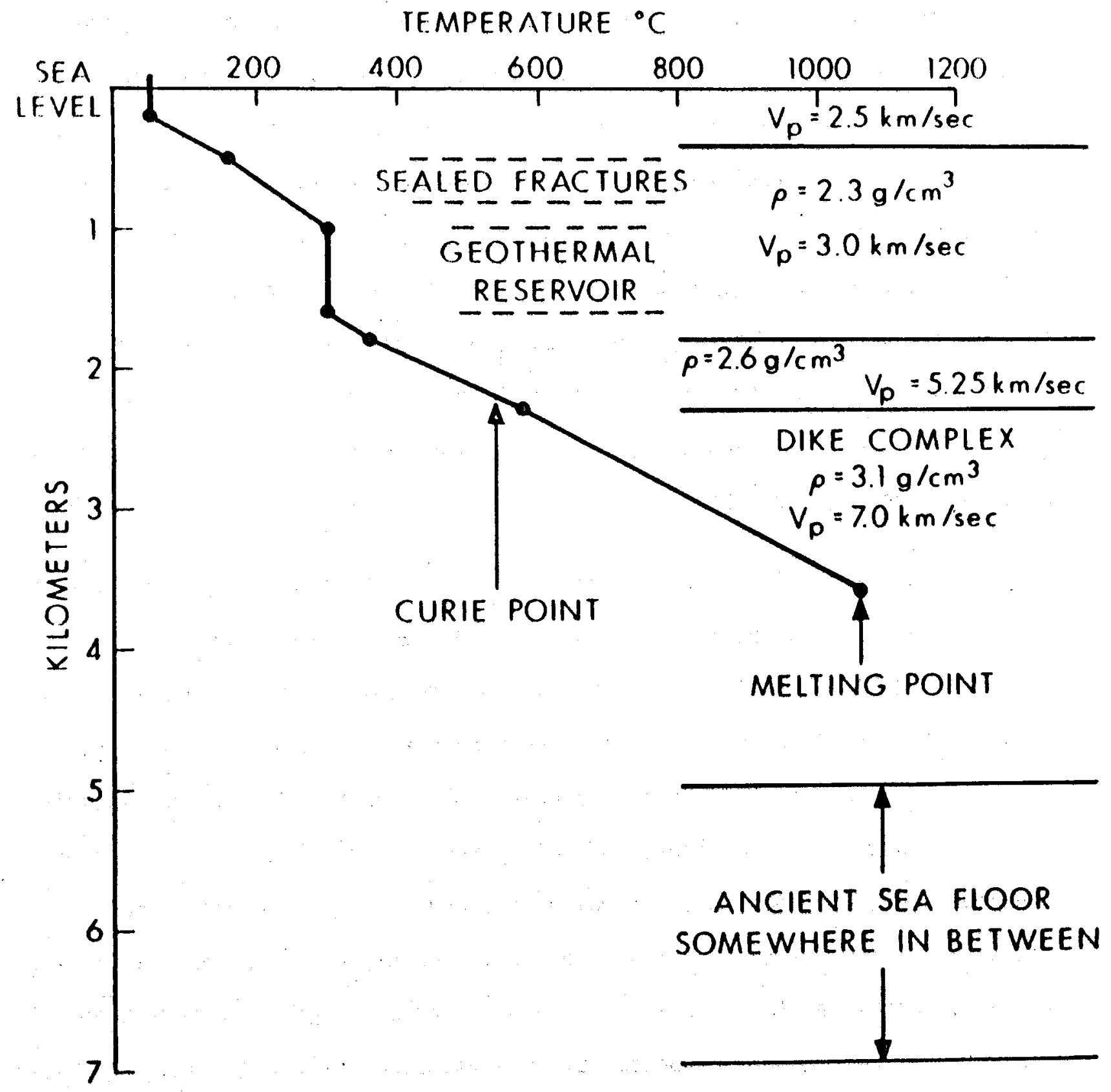

Figure 4-10

Temperature-Depth Profile of the East Rift

From Furumoto, 1979 
Forceful intrusion of magma into the passageways produces tensional stresses and the gravitational slumping of the mountain mass contributes to a stress build up. When stresses attain critical values, they fracture the rocks. Groundwater of meteoric origin can then circulate through the fractures and cracks. As water circulates and convects through the lower hot regions to the cooler higher regions, the self-sealing process explained in previous sections eventually forms a caprock to trap a pocket of hot water. Due to the continual conductive supply of heat from below, the trapped aquifer becomes a high temperature hot water geothermal reservoir. As the caprock is not a perfect seal, leakages from the geothermal reservoir disturbs the Ghyben-Herzberg lenses above.

If this model is valid, a geothermal reservoir can be faund only where the self-sealing process has formed a caprock. An exploration program would have to be designed to find the caprock and reservoir below. Low electrical resistivity anomalies by themselves do not mean a high potential geothermal reservoir, as saline water heated to only $130^{\circ} \mathrm{C}$ can be of very low resistivity. If streaming water is the source of self potential anomalies, as claimed by Zablocki, then self potential anomalies may indicate where hydrothermal fluids are leaking from a confined aquifer. The higher the potential difference, the higher the velocity of leakage, and the higher the confining pressure of the aquifer. Geochemical surveys, especially for silica content, are useful, as they locate areas where the watertable has been contaminated by leakages from the reservoir. Microearthquake clusters can indicate reservoir volume, because as hydrothermal alteration weakens the rigidity of rocks, the prevalent stresses will fracture the basalts.

In petroleum exploration, caprocks are definable by active seismic methods. 
Unfortunately, these methods will not work in Puna, because the acoustic mismatch between the caprock formation and the surrounding basalt matrix is practically insignificant.

A geothermal reservoir can only exist where the convecting fluids have had time to build a sufficiently thick caprock by the self-sealing process. Areas of very recent eruptive activity therefore are not old enough for a reservoir to have formed. Then again, if an area has been left undisturbed too long, secondary minerals completely clog the fractures and cracks so that no reservoir can exist.

\subsubsection{Quality of the HGP-A Reservoir}

As a rather comprehensive detailed collection of chemical data on HGP-A has been published, this section will report only on those parts that are relevant to this project. Data found in other reports are also incorporated into this section.

Temperature. The steady state shut-in temperature profile of the well is reported in Figure 4-11. Although there are minor variations, the profiles are consistent among themselves. The base temperature of the reservoir is $3000 \mathrm{C}\left(572^{\circ} \mathrm{F}\right)$. Figure $4-12$ indicates that when the well flashes through a $1-3 / 4$ inch diameter orifice, the temperature increases linearly from $230^{\circ} \mathrm{C}$ $\left(446^{\circ} \mathrm{F}\right)$ at the weil head to $260^{\circ} \mathrm{C}\left(500^{\circ} \mathrm{F}\right)$ at the bottom of the well. For practical purposes a well head temperature of $230^{\circ} \mathrm{C}$ can be expected for commercial use.

Permeability. The well as a whole can be described as being tight. From measurements of flow, the overall formation transmissibility is estimated to be low. Although downhole data on premeability have not been taken, 


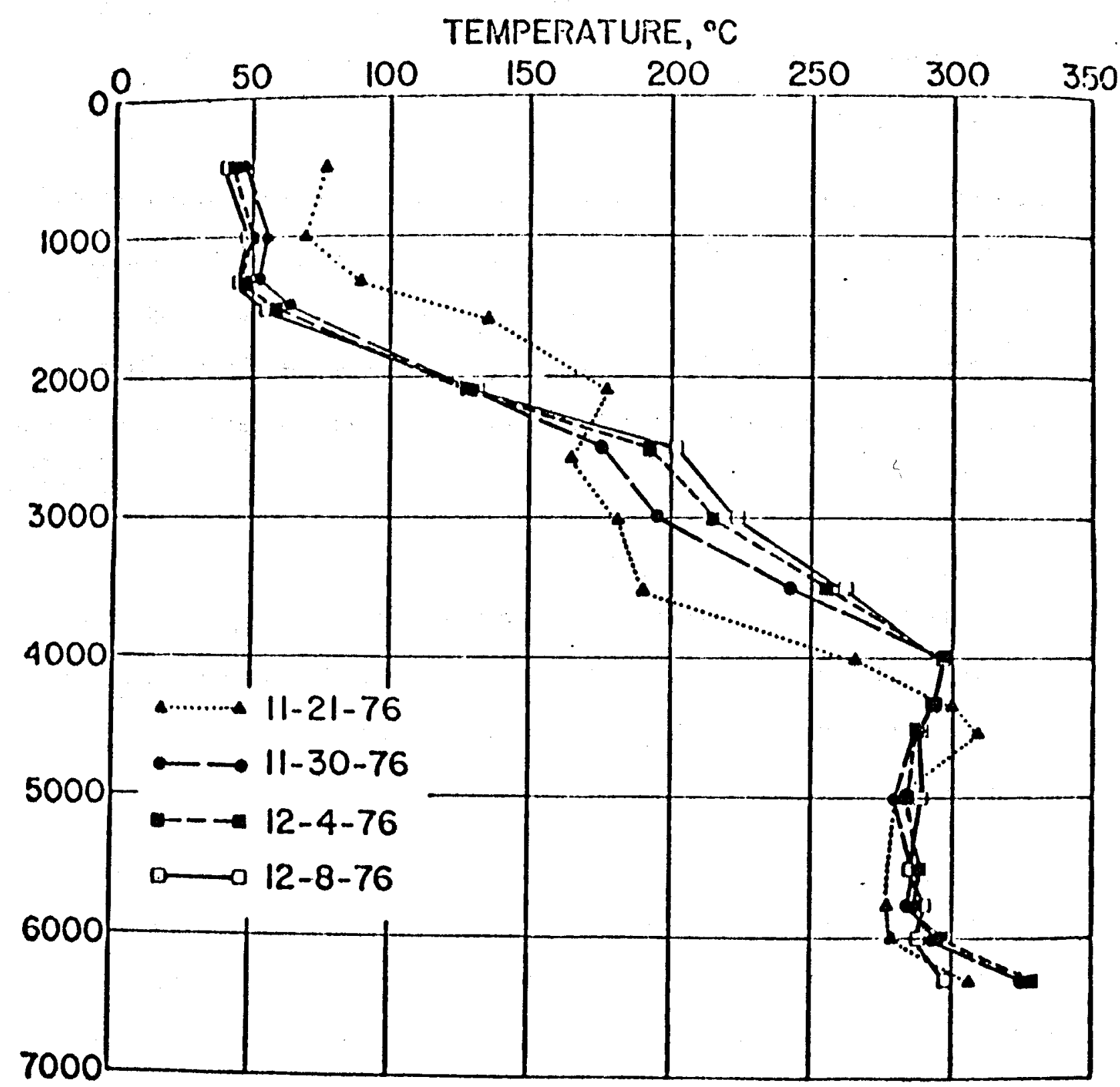

Figure 4-11

HGP-A Shut-in Downhole Well Temperatures

From Kroopnick et a1, 1977 


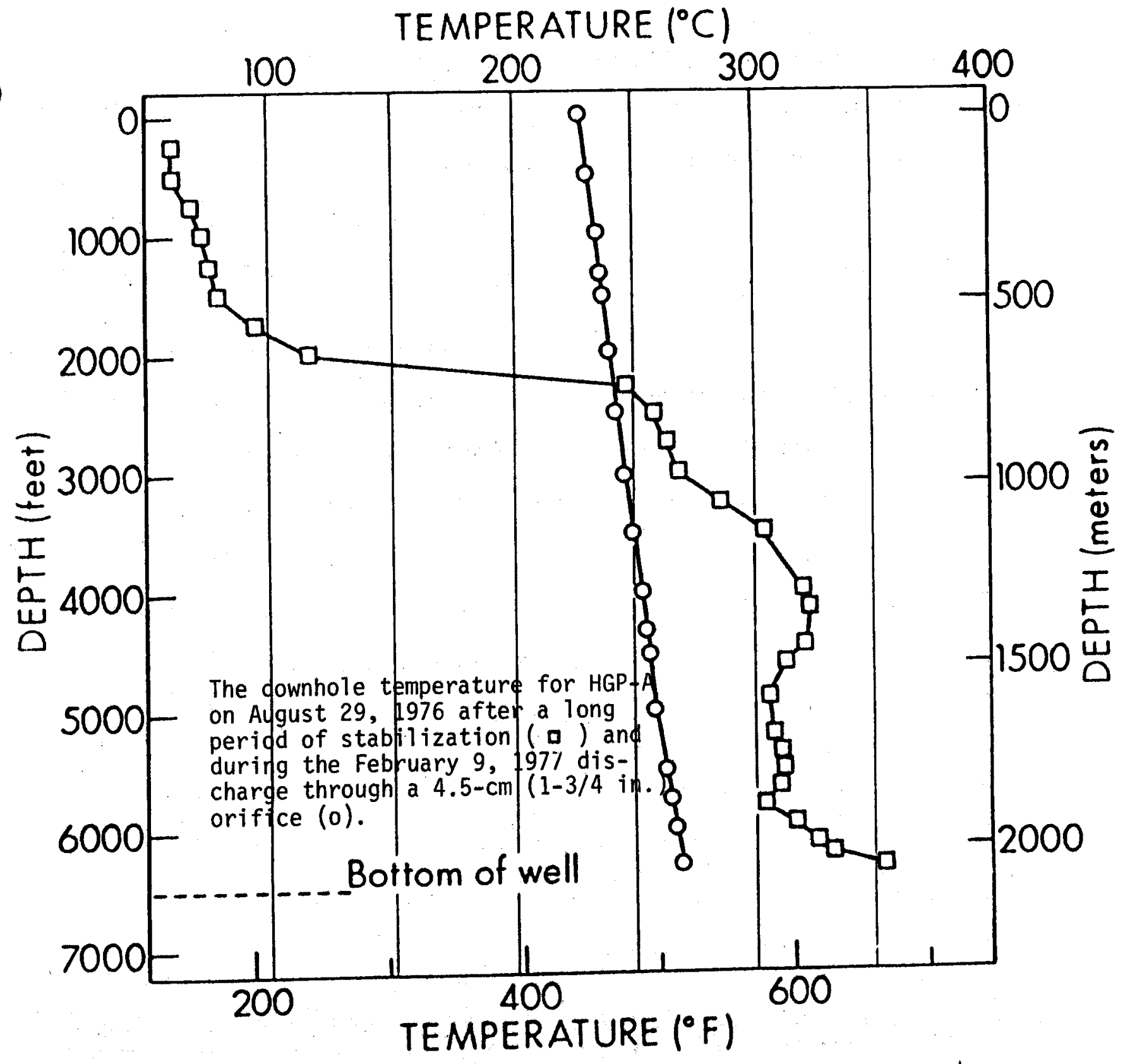

Figure $4-12$

HGP-A Shut-in and Production Downhole Well Temperatures

From Kroopnick et a1, 1977 
examination of core samples reveals that permeability varies according to whether the fractures are filled by secondary minerals or not. From $800 \mathrm{~m}$ $(2620 \mathrm{ft})$ to $1200 \mathrm{~m}(3940 \mathrm{ft})$, the permeability is low, then it rises betweem $1200 \mathrm{~m}(3940 \mathrm{ft})$ and $1500 \mathrm{~m}(4920 \mathrm{ft}$ ) as the fractures open, and finally becomes low again from $1500 \mathrm{~m}(4920 \mathrm{ft})$ to the bottom of the hole.

The isothermal section of the temperature profile from $1.300 \mathrm{~m}(4264 \mathrm{ft})$ to $1900 \mathrm{~m}(6000 \mathrm{ft})$ may suggest convective motion of hydrothermal fluids, but the low permeability of rocks argues against such conjecture. Instead of convective motion, a better explanation is that water exuding from a permeable layer at $1300 \mathrm{~m}$ depth $(4260 \mathrm{ft}$ ) pours into the well bore and then down the bore to $1900 \mathrm{~m}(6000 \mathrm{ft})$, where it exits through another permeable layer. This explanation is less elegant than convective motion, but the explanation is in more agreement with observed data.

Salinity. The overall salinity of the well is low, in spite of the proximity of the sea shore. Dilution amounts to approximately $90 \%$. This has led to speculation that an impermeable barrier such as a solid dike, prevents the sea water from penetrating the reservoir.

Acidity. Analysis of water samples at the well head, whether from condensation or from the weir box, shows $\mathrm{pH}$ values from 7 to 8.8 , indicating neutral conditions, but samples from depth have higher acidity. One sample from $2270 \mathrm{ft}$ depth had a $\mathrm{pH}$ value of 1.4. In Figure 4-13 several runs of $\mathrm{pH}$ values are plotted. The acidity is due to free hydrogen sulfide and carbon dioxide.

On the other hand, mineralogical examination of core samples indicates that the downhole environment ranges from neutral to slightly alkaline. Such 


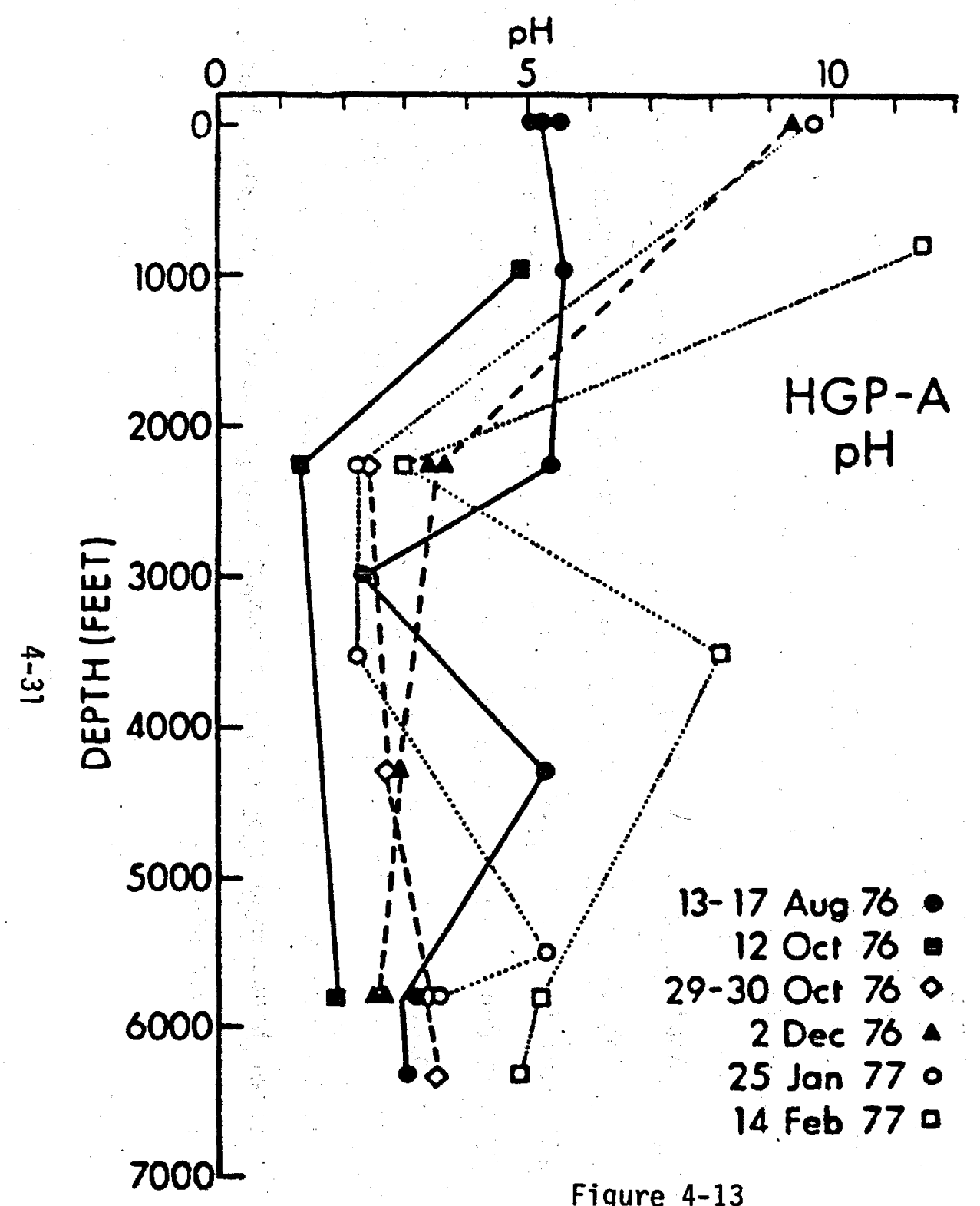

Figure $4-13$

The Downhole Distribution of $\mathrm{pH}$ for HGP-A.

From Kroopnick et a 1, 1977

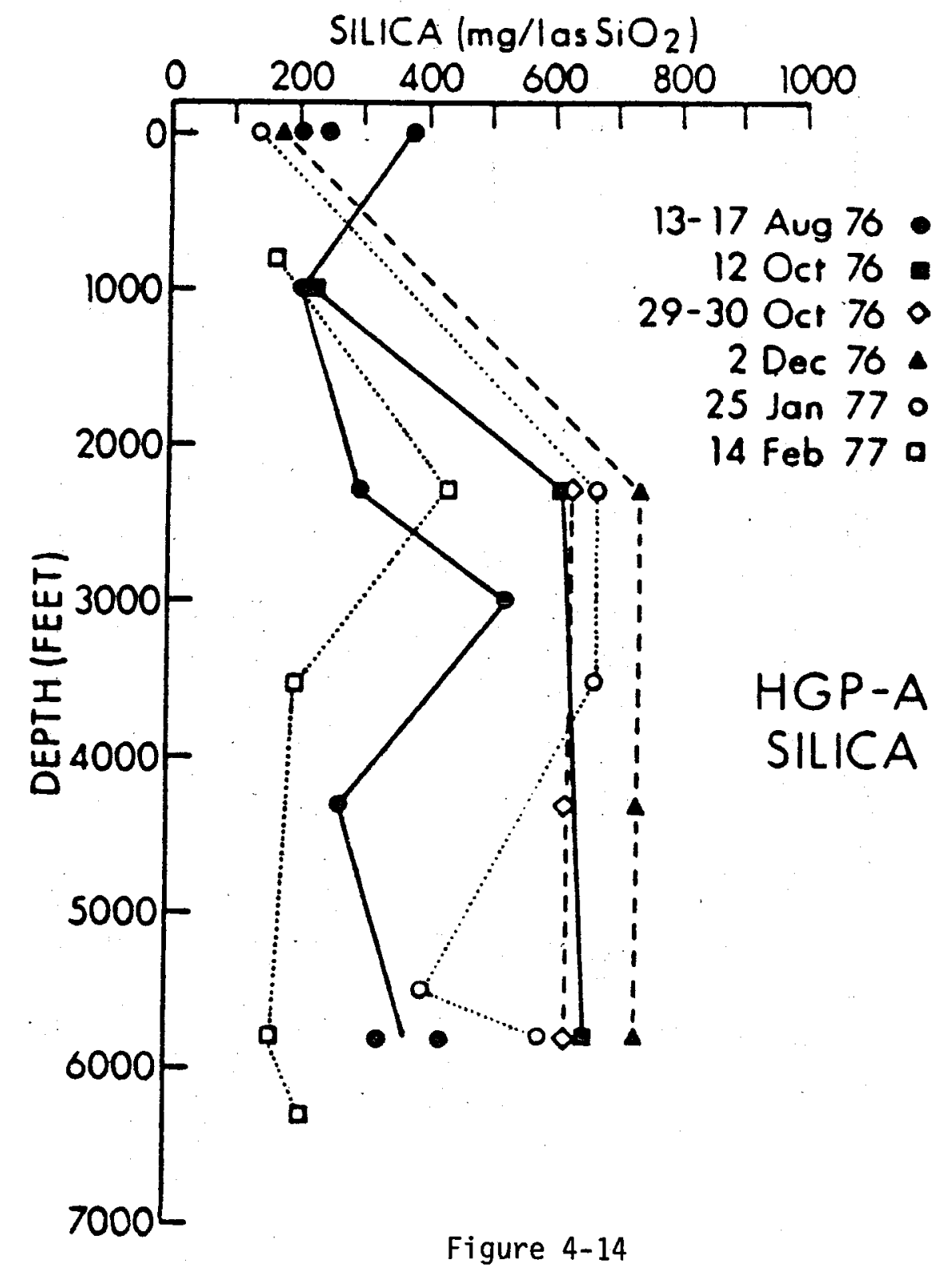

The Downhole Distribution of Silica for HGP-A.

From Kroopnick et a1, 1977 
differences between water samples and rock samples have also been observed in geothermal wells in Japan. A quantitative explanation for the discrepancies has yet to be proposed.

Silica. Silica content is about $380 \mathrm{mg} / 1$ iter at the well head, but higher, perhaps $700 \mathrm{mg} / 1$ iter, at certain depths as indicated by Figure 4-14. The problem of silica deposition is treated in the engineering section of this report.

Mercury. The ambient level of mercury, whether in the oxidized form or in reduced form, is high at all areas where there are surface volcanic manifestations in Hawaii. During flashing at HGP-A, the airborne mercury content varied from 7 to 18.8 micrograms per cubic meter. The question of mercury is addressed in the environmental section of this report.

\subsection{COMPARISON OF THE PROPOSED SITE AND THE HGP-A SITE}

The present project proposes drilling at what has been called Site $B$, to distinguish it from the HGP-A location of site A. As HGP-A came across a geothermal reservoir, a comparison of geophysical indicators at both sites gives a clue as to what can be expected at Site B. The comparison shows better indicators at Site B, so that a field superior to HGP-A should be encountered at Site B. Table 4-1 compares the geophysical parameters of both sites.

In the map of Figure 4-15 are shown some of the anomalies for comparison. First, to be oriented, the open triangle indicates the location of HGP-A, while the black triangle points to the general preferred location for drilling at Site B. The low electrical resistivity anomalies detected in the dipole-dipole surveys are delineated by heavy lines as the Western, 
TABLE 4-1

COMPARISON OF GEOPHYSICAL PARAMETERS FOR GEOTHERMAL EVALUATION

\begin{tabular}{|c|c|c|c|}
\hline Type of Survey & HGP-A & Site B & Reference \\
\hline Infrared Scanning & Anomaly $1 \mathrm{~km}$ away & Anomaly at site & Abbott, 1974 \\
\hline Electrical Resistivity & No anomaly & 5 ohm-m anomaly & Keller, 1977 \\
\hline Microearthquake & About 1 per day & Several per day & $\begin{array}{l}\text { Suyenaga and Furumoto, } \\
1978 \\
\text { Mattice and Furumoto, } \\
1978\end{array}$ \\
\hline We11 Temperature & $92^{\circ} \mathrm{C}, 1 \mathrm{~km}$ away & $102^{\circ} \mathrm{C}$ at site & Epp, 1975 \\
\hline Silica Content & $100 \mathrm{ppm}$ & No data available & Fan and McMurtry, 1976 \\
\hline Self Potential & 500 millivolts & 700 millivolts & Zablocki, 1977 \\
\hline Magnetic & No anomaly & Anomaly nearby & Norris, 1976 \\
\hline
\end{tabular}




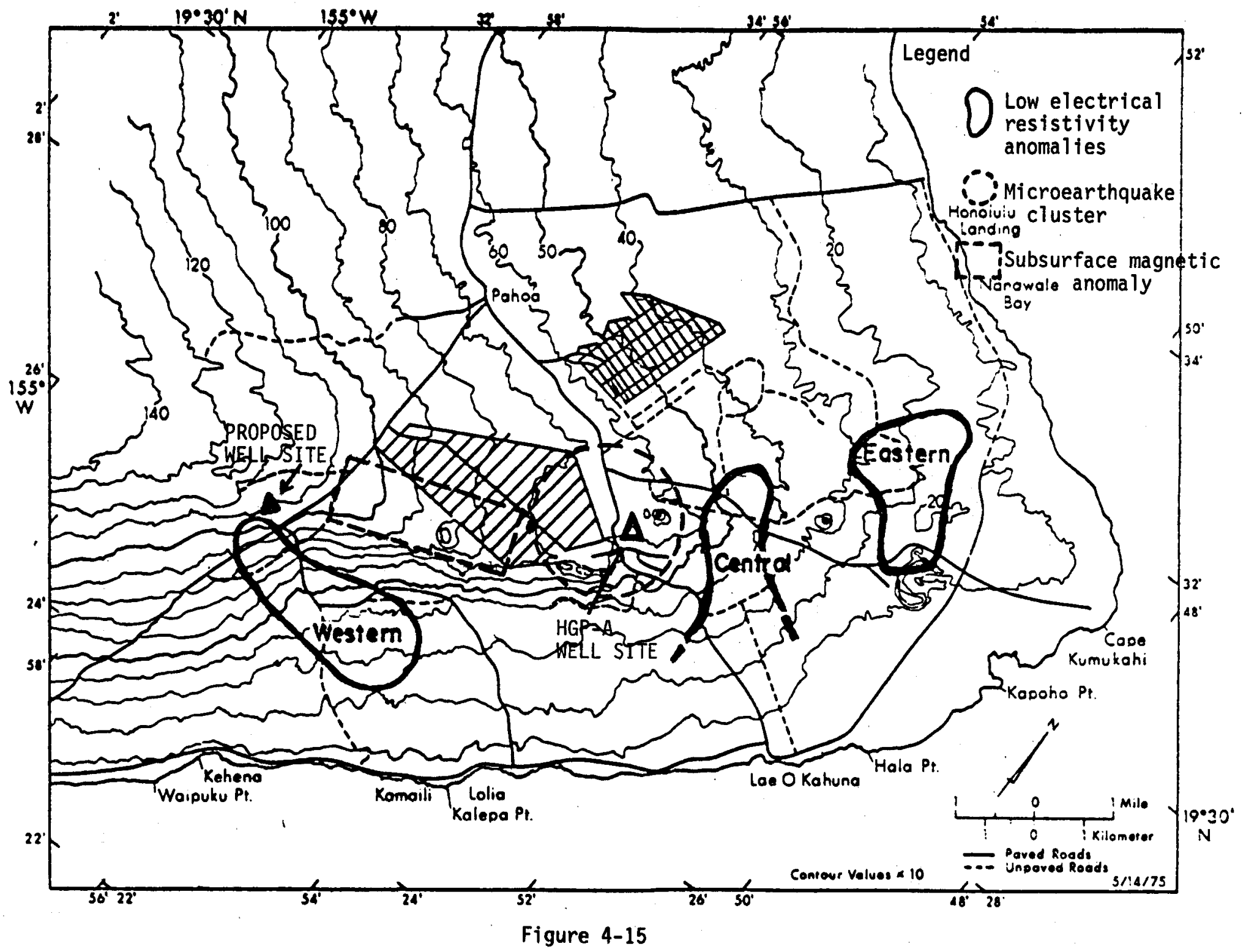

Geophysical Anomalies of Puna 
Central and Eastern anomalies. HGP-A is about a kilometer from the Central anomaly, but Site B would be on the edge of the Western anomaly. The profile of resistivity versus depth for Site B shows a section of 5 ohm-m from a depth of $0.6 \mathrm{~km}(1970 \mathrm{ft})$ to a lower bound of $2 \mathrm{~km}(6500 \mathrm{ft})$. Obviously electrical resistivity data suggests Site B to be superior, but in the context of Hawaiian geology, the physical meaning of low resistivity is not certain. HPG-A was found in a region of non-anomaly. If anything, the proposed drilling will answer the question: What does low electrical resistivity mean in Puna?

The broken line circling HGP-A indicates the reservoir outlined by microearthquake data. The map does not show a comparable seismic area around Site B, but a two station survey carried out in 1978 near Site $B$ revealed that Site B was seismically more active than the HGP-A site. Because the monitoring program could field only two portable seismographs, epicenters were not determined. However, from arrival times of $P$ and $S$ waves, distances from the seismographs to the earthquakes could be determined. A dense cluster of earthquakes within a radius of $2 \mathrm{~km}(1.2 \mathrm{mi})$ from site $B$ was recorded.

The rectangular anomaly in Figure $4-15$ is a shallow structure detected by surface magnetic survey and labeled as a shallow dike complex in Figure 4-9. The structure is probably an aggregate of dikes, acting like a chimney, from the lower main dike complex. If there is a geothermal reservoir at Site B, it should be lodged in the elbow between the main dike complex and the shallow dike complex.

In Figure 4-16 and 4-17, the self potential anomalies of the two sites are compared. Again, if the self potential data are indicators, Site B 


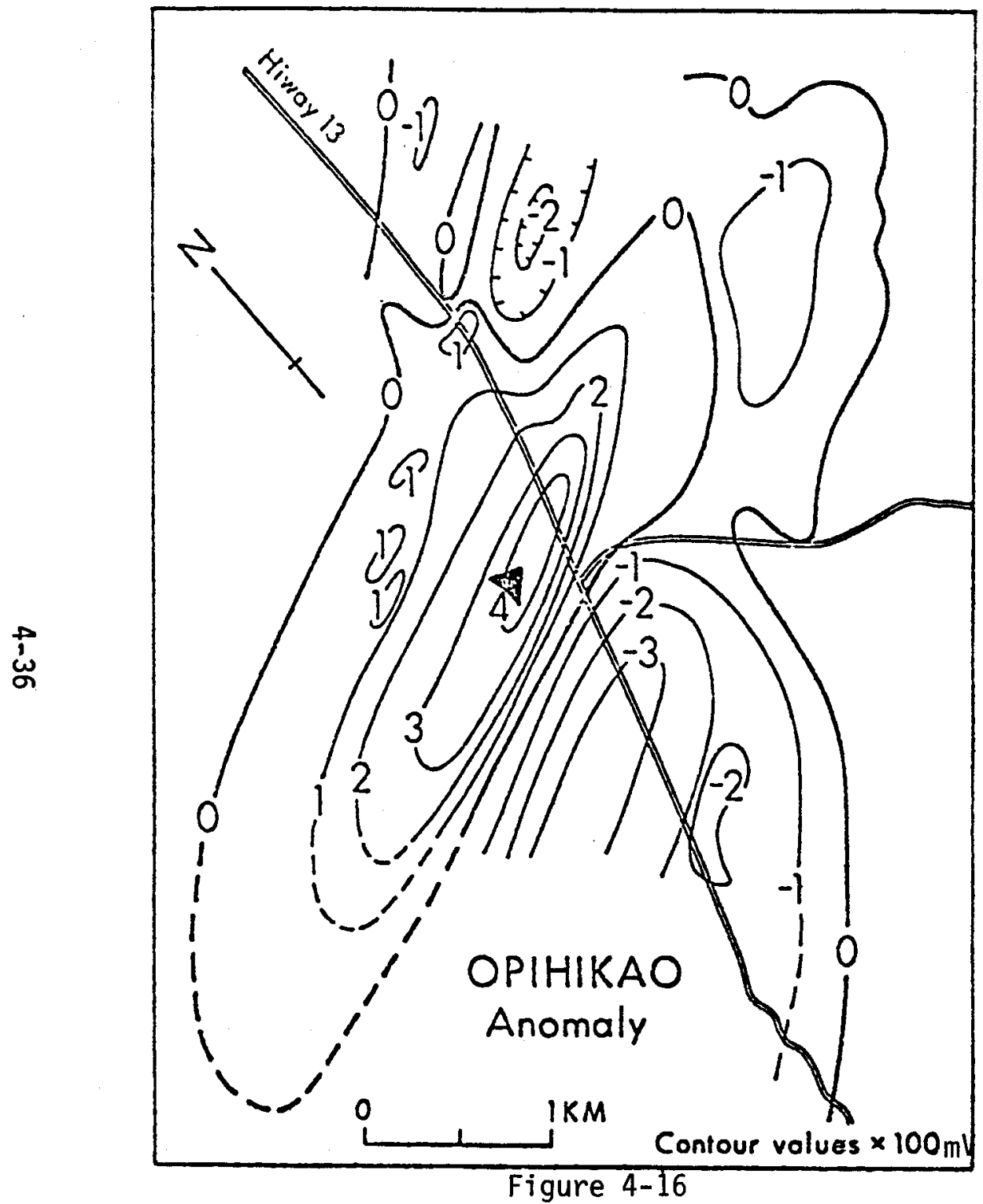

Self Potential Contours at Site B

Adapted from Zablocki, 1977

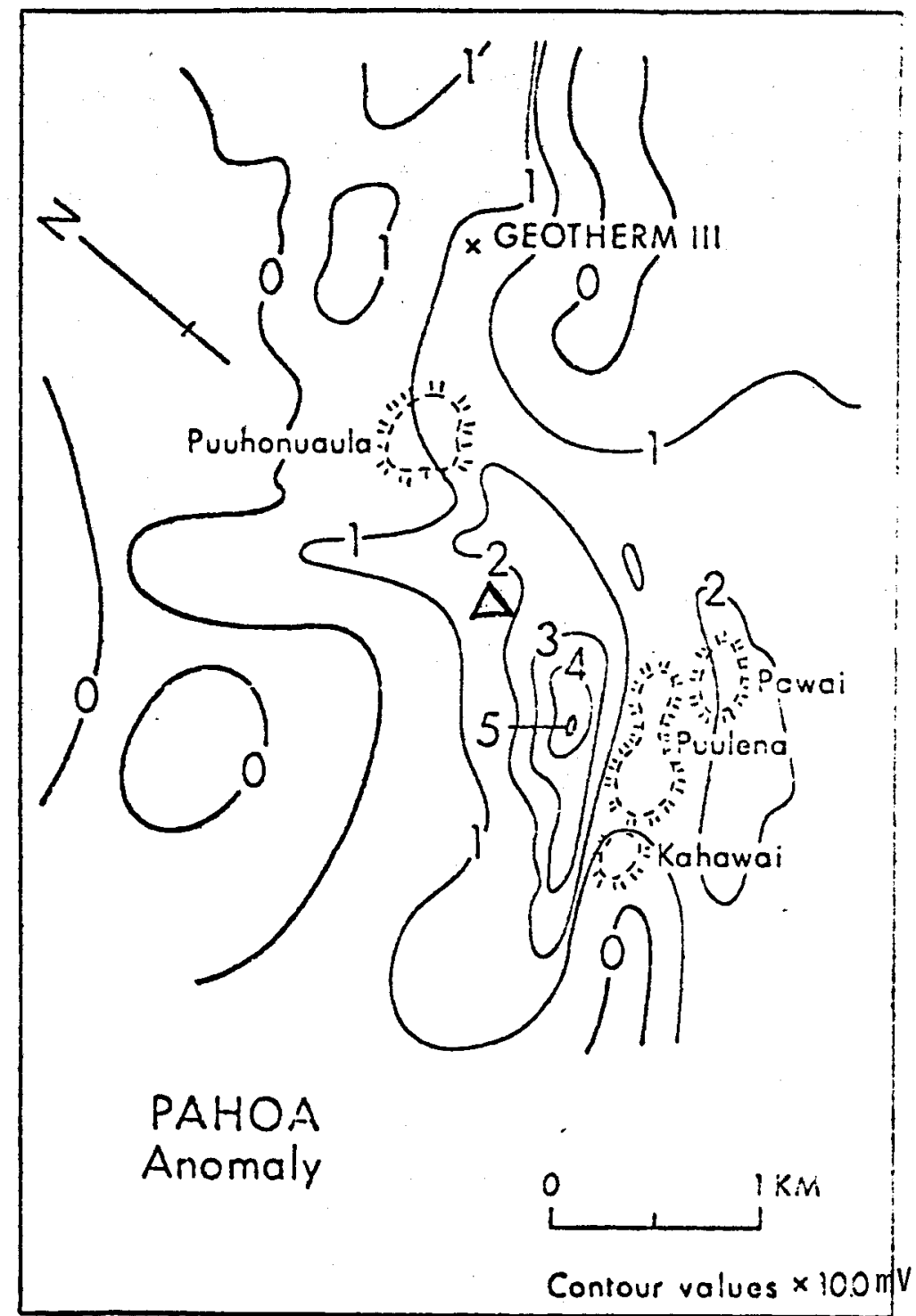

Figure 4-17

Self Potential Contours at Site A (HGP-A) Adapted from Zablocki, 1977 
is superior.

The preferred location for drilling is shown in Figure 4-16. It is

located on the northwestern margin of several geophysical anomalies. If the preferred location produces a poor hydrothermal resource, more holes can be drilled to the southeast, across Highway 130. Should there be no geothermal reservoir at Site $B$ even after drilling these holes, an awesome conclusion must be drawn, that geophysical surveys are meaningless for geothermal exploration in Hawaii. 


\section{REFERENCES}

4-1 Broyles, M. L., et al., "Structure of the Lower East Rift Zone of Kilauea Volcano, Hawaii from Seismic and Gravity Data," from J. Volcan. Geotherm. Res., (in press), 1978.

4-2 Eaton, J. P., "Crustal Structure and Volcanism in Hawaij" in "The Crust of The Pacific Basin," Am. Geophys. Un. Monog., 6:13-29, 1962.

4-3 Eaton, J. P., and Murata, K. J., "How Volcanoes Grow," from Science, 132:924-938, 1960 .

4-4 Epp, D., Well Temperature Survey, May to December, 1975, from Hawai i Geotherm. Proj. Report, Initial Phase II, pp. 36-39, 1976 .

4-5 Facca, G., and Tonani, E., "Self-Sealing Geothermal Field," from Bul1. Volcanol, 30: 271-173, 1957.

4-6 Fan, P. F., et al., "Task 2.5, Petrography," from Hawai i Geothermal Project, Phase II; A Proposal submitted to Energy Research and Development Administration, pp. 83$91,1976$.

4-7 Fiske, R. S., and Jackson, E. D., "Orientation and Growth of Hawaiian Volcanic Rifts: The Effect of Regional Structure and Gravitational Stresses," from Proc. Roy. Soc., London, Ser A, 329: 299-326, 1972.

4-8 Furumoto, A. S., Prel iminary Studies for Geothermal Exploration in Hawaii, 1973 - 1975, HIG-75-5, Hawaij Institute of Geophysics, December, 1977.

4-9 Furumoto, A. S., "Nature of Magma Conduit under the East Rift Zone of Kilauea Volcano, Hawaii," from Bull Volcanol, (in press), 1979.

4-10 Keller, G. V., The Opihikao Prospect, Microgeophysics, Inc., Boulder, Colorado, 1975.

4-11 Keller, G. V., et a1., Geoelectric Studies of the East Rift, Kilauea Volcano, Hawaij Island, HIG-77-15, Hawai Institute of Geophysics, December, 1977. 
4-12 Klein, D. P., and Kauahikaua, J. P., GeoelectricGeothermal Exploration on Hawaii Island: Prel iminary ResuTts, HIG-75-6, Hawaii Institute of Geophysics, January, 1975.

$4-13$

Koyanagi, R. Y., et a1., "Seismic Activity on the Island of Hawaii, 1970-1973, in "Geophysics of the Pacific Ocean Basin and its Margin," from Am. Geophys. Un., Monog. 19: 169-172, 1976.

4-14 Kroopnick, P. M., et al., Hydrology and Geochemistry of a Hawaiian Geothermal System: HGP-A, HIG-78-6, Hawaii Institute of Geophysics, May, 1978.

4-15 Macdonald, G. A., "Structure of Hawaiian Volcanoes," from Verh. Koninj. Ned. Geol. Mijn. Genoots., 16: 1-22, 1956.

4-16 Macdonald, G. A., "Geological Prospects for the Development of Geothermal Energy in Hawaii," from Pacific Sci., 27: 209-219, 1973.

4-17 Macdonald, G. A., Geology and Groundwater Hydrology in Preliminary Studies for Geothermal Exploration in Hawaii, 1973-1975, HIG-75-5, Hawaij Institute of Geophysics, December, 1977.

4-18 Malahoff, A. and McCoy, F., "The Geologic Structure of the Puna Submarine Ridge, Hawaii," from Journ. Geophys. Res., 72: 541-548, 1967.

4-19 Mattice, M., and Furumoto, A. S., "Microearthquake Study of the Opihikao Anomaly, Puna, Hawai i," in Seismic Studies on Kilauea Volcano, Hawaii Island, HIG-78-8, Hawaii Institute of Geophysics, November, 1978.

4-20 Minakami, T., "Physical Nature of Source Parameters of Volcanic Earthquakes," in Utilization of Volcano Energy, Sandia Lab., 191-204, 1974.

4-21 Moore, J. G. "Relationship Between Subsidence and Volcanic Load," from Bull. Volcanol., 34: 562-576, 1971.

4-22 Moore, J. G., and Fiske, R. S., "Volcanic Substructure Inferred from Dredge Samples and Ocean Bottom Photographs, Hawaii," from Geol. Soc. Am. Bul1., 80: 1191-1202, 1969.

4-23 Norris, R., "Puna Magnetics," from Haw. Geotherm. Proj. Rep., Initial Phase II, 1976. 
4-24 Richter, D. H., and Eaton, J. P., "The 1959-1960 Eruption of Kilauea Volcano," from The New Scientist, 7: 994-997, 1960.

4-25 Richter, D. H., et al., "Chronological Narrative of the 1959-1960 Eruption of Kilauea Volcano, Hawaii," from Geol. Surv. Prof. Paper 537-E, 1970.

4-26 Siegel, B., and Siegel, S. M., "Task 4.1, Geotoxicology," from Hawaii Geotherm. Proj. Rep., Phase III, We11 Testing and Analysis, 1977.

4-27 Stearns, H. T., and Macdonald, G. A., Geology and Groundwater Resources of the Island of Hawaii, Hawaii Division of Hydrography, Bulletin No. 9, 1946.

4-28 Suyenaga, W., and Furumoto, A. S., "Microearthquake Study of the East Rift Zone of Kilauea, Puna, Hawaii," in Seismic Studies on Kilauea Volcano, Hawaii Is land, HIG-78-8, Hawaij Institute of Geophysics, November, 1978.

4-29 Swanson, D. A., et al., "Displacement of the South Flank of Kilauea Volcano: The Result of Forceful Intrusion of Magma into the Rift Zone," from Geol. Surv. Prof. Paper No. 963, 1976.

4-30 Yamasaki, T., "Report on Analysis of Core Samples from HPG-A," (personal communication), 1978.

4-31 Zablocki, C. J., "Self-Potential Studies in East Puna, Hawaii," in Geoelectrical Studies of the East Rift, Kilauea Volcano, Hawaii Island, HIG-77-15, Hawai i Institute of Geophysics, December, 1977. 


\section{Section 5}

\section{DESIGN SYNTHESIS CRITERIA}

This section outlines the criteria on which the project is designed. The value of hydrothermal fluid utilization is clearly in the substitution of steam generated by the firing of bagasse and fuel 0 il. In 1977, Puna Sugar Company purchased' nearly one million dollars worth of fuel oil. Eliminating this oil dependency and reducing the bagasse consumption can lead to alternative product manufacturing potential. Bagasse itself is a valuable feedstock and alternative products from bagasse is well documented. Among the by-products that have been produced in other cane sugar growing areas are briquettes, methane, producer gas, pulp and paper, particle board, fiberboard, furfural, and certain plastics.

It became evident early in this study, however, that the most secure form of generating compensating income for the required geothermal investment is through the continued firing of the bagasse for steam production. Direct utilization of geothermal steam for process demands reduces the need for bagasse generated steam in process. The utilization of that bagasse steam can then be directed toward increased electrical production and export. Puna Sugar already contracts to supply firm power to HELCO. While the compensation for energy sales is not particularly attractive, it does offer a ready market which requires only nominal factory retrofit capital expenditures to develop. 


\subsection{CANE PRODUCTION}

The projected annual cane production generally will increase up to 1982 . From 1982 through 2002, cane tonnage will be constant. Any further increase, which at this point is not planned, will be a proportional increase of acreage versus processing capacity. For the purpose of this study, an annual cane production of $1,185,000$ tons is used.

\subsection{WEEKLY FACTORY SCHEDULE}

The factory is operated continuously from 3 pm Monday afternoon until 3 pm Saturday on a three-shift, five day per week schedule. The boiler and turbogenerator, however, operate continuously on a four-shift, seven day schedule because of the power contract commitments to HELCO. The period from Saturday afternoon to Monday afternoon is used for weekly wash down, cleaning, and maintenance of the cane factory equipment.

\subsection{CAMPAIGN DURATION}

The term campaign and grinding year are used synonomously in the world cane sugar industry, with the latter more prevalent in Hawaii. However, since Puna Sugar has abandoned the more conventional milling train which "grinds" the cane, it was decided to use the term campaign throughout this report to indicate the length of the cane operating season.

The duration of the campaign generally varies from 46 to 48 weeks depending on a number of factors including mechanical breakdowns, weather, and size of the crop. The electrical power supply agreement between Puna Sugar and HELCO calls for a continuous four-week annual boiler and turbogenerator scheduled maintenance period. Hence, oil must be burned in the boiler to generate steam should the factory campaign be less than 
48 weeks. A campaign duration of 46 weeks has been assumed for this project, necessitating oil consumption for boiler operation during two weeks of the year.

The factory and power plant both begin operation about the first of February after annual repairs, with the factory terminating its campaign in mid-December. The boiler and turbogenerator facility completes the calendar year and is down for annual maintenance only during January. During the operating year, the factory stops for nine holidays, but the power plant continues operation for the entire period.

\subsection{PROCESS RATE}

Allowing for the weekly production schedule, unscheduled stops, campaign duration, holidays, and crop size, a production rate of 175 tons prepared cane per hour has been calculated for the baseline process rate. This translates to approximately 4000 tons cane per day.

\subsection{EQUIPMENT}

Results of an equipment evaluation has indicated all existing equipment capacities are adequate to meet the process demand of the baseline conditions throughout the project period. There is concern, however, in the reaction of the process juice steam and equipment with the hydrothermal fluids. Particular concerns are in several areas.

- The copper-based alloys employed in the process equipment will react badly with chlorides found in geothermal brines.

- Extensive use of Type 304 stainless steel is made in the pipelines and process equipment of the factory. Welded joints normally are not heat treated and there is a possibility of chloride stress corrosion failure at the welds. 
- Use of geothermal brines in juice heat exchangers will introduce the danger of leakages and heavy metals contamination.

To prevent such occurrences, any factory geothermal retrofit design must include a form of a binary system to exclude geothermal fluids from directly contacting existing factory equipment.

\subsection{RESOURCE SITE AND CHARACTERISTICS}

Initial efforts in this work were predicated on a site specific use and a generic resource. However, as the study progressed, the preliminary economics indicated it might be feasible to pipe steam from the East Rift Zone of Kilauea, located some 15 miles south of the factory. Several other considerations caused the investigators to favor a resource in the rift zone.

- Extensive ground surveys had already been completed in the area with respect to geothermal potential.

- The resource area being considered was known as Site B, shown in Figure 4-4. This location was originally recommended by the two senior geophysicists in the Hawaii Geothermal Project as the site with the greatest geothermal resource potential. As a matter of interest, the HGP-A well was finally drilled at Site $A$ of Figure $4-4,3.5$ miles from Site B. Both areas lie within the East Rift Zone of Kilauea.

- While a generic study in terms of resource quality has some usefulness, a site specific well location is of much greater interest to Puna Sugar and USDOE. The ultimate goal is not promising feasibility studies, but early commercialization of geothermal potentials. A specific well site will foster this end. 
- Most of the immediate exploratory and development interest will be associated with the East Rift Zone. Hence it is expected that the rift zone geothermal potential will be defined sooner than other promising areas on the island. With uncertainties of reservoir potential reduced, commercialization can be expected sooner.

- The study need not be contingent on any Hawaii Institute of Geophysics (HIG) field work in the Keaau area. In any case, it appeared that definitive Keaau data from HIG would not be available within the time frame of this study.

- Puna Sugar owns approximately 1100 acres in fee simple within Site $B$ and immediately adjacent to it. In addition, it owns another 1800 acres in the general area. Much of this acreage are potentially promising geothermal production sites.

- The State of Hawaij claims a substantial portion of all mineral rights in the East Rift Zone. Aside from reducing its oil dependency, it therefore has a potential financial interest through mining leases and royalties, in development of geotherma1 resources.

For the above mentioned reasons, midway through the project, a request was made to the Division of Geothermal Energy to concentrate the study efforts on a site specific use and a specific resource at Site B. Permission was subsequently granted and the work efforts were channeled in this direction.

While exploratory work has to a large extent been completed for the proposed resource site, deep exploratory drilling has yet to be 
attempted. However, due to the proximity of the HGP-A well and the similarity of survey data for both sites, the HGP-A data fundamentally forms the basis of well characteristics for this study. 


\section{REFERENCES}

5-1 Paturau, J. M., By-Products of the Cane Sugar Industry, New York: Elsevier Publishing Co., 1969. 
Section 6

FUNCTIONAL DESIGN

This section describes the specific alternative developed for the proposed utilization of geothermal resources at the Puna Sugar factory in Keaau. It includes discussion of the well site facilities, pipeline transmission, factory retrofit requirements and process flow schematics. The remaining portion of the section discusses electric power production and manning requirements.

\subsection{RECOMMENDED SYSTEM}

The proposed system incorporates three separate but interrelated sections. Figure 6-1 represents a highly simplified schematic which depicts these sections as well site facilities, resource transmission, and the factory retrofit. The project area relative to the Puna district is shown in Figure 6-2.

Several criteria must be evaluated to determine a choice of process and equipment including nature of the resource, topography, local habitation and facilities, utilities, and the distance of transmission to the end user. Of particular concern is the 16 mile pipeline transmission distance from the East Rift Zone to the Puna Sugar factory in Keaau. Owing to the unusually long pipeline, steam will condense in the pipe and must be collected and rejected through steam traps located at spaced intervals along the pipe run. Should geothermal steam be transported in the pipe, 


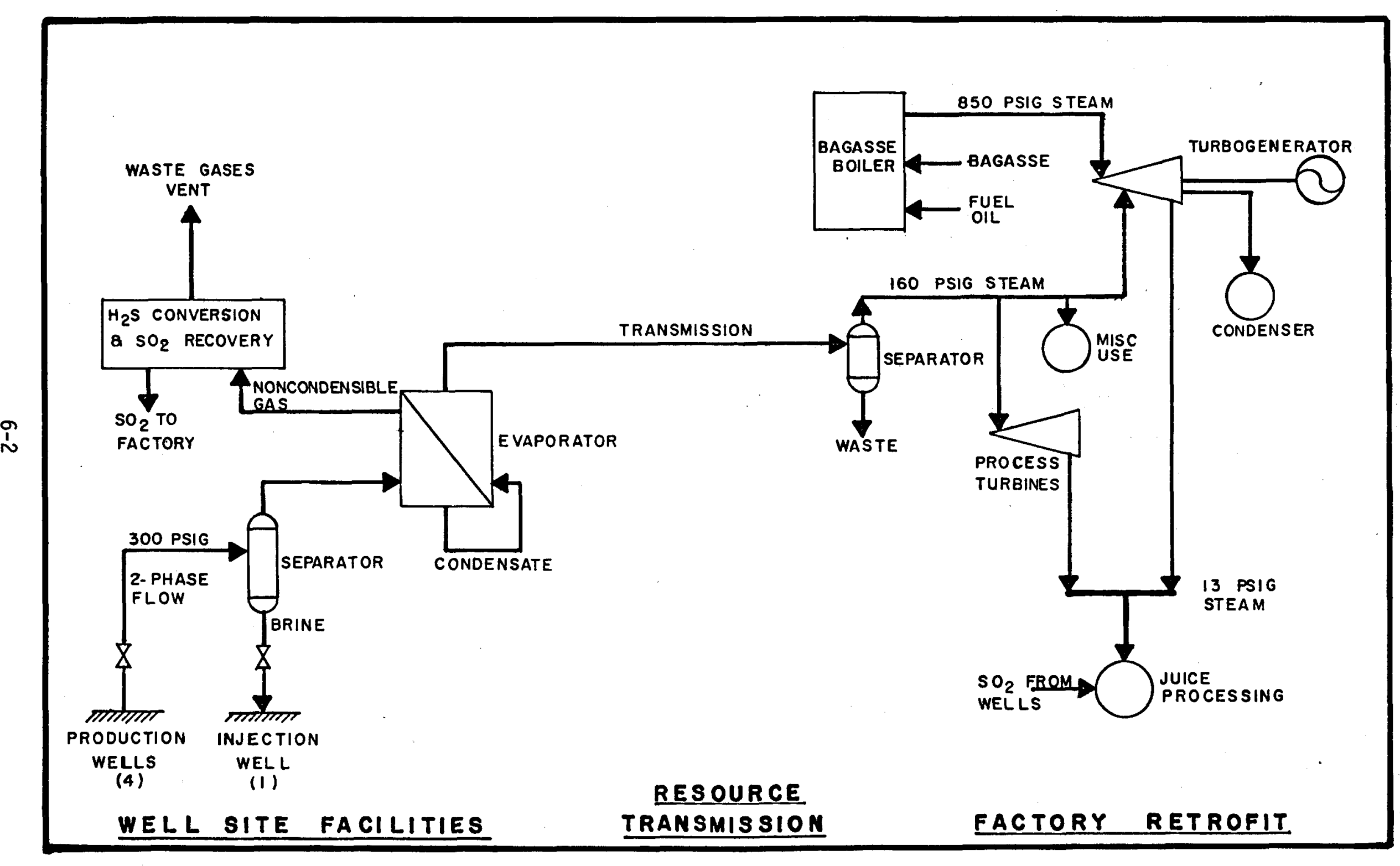

Figure 6-1

Simplified Proposal Schematic 


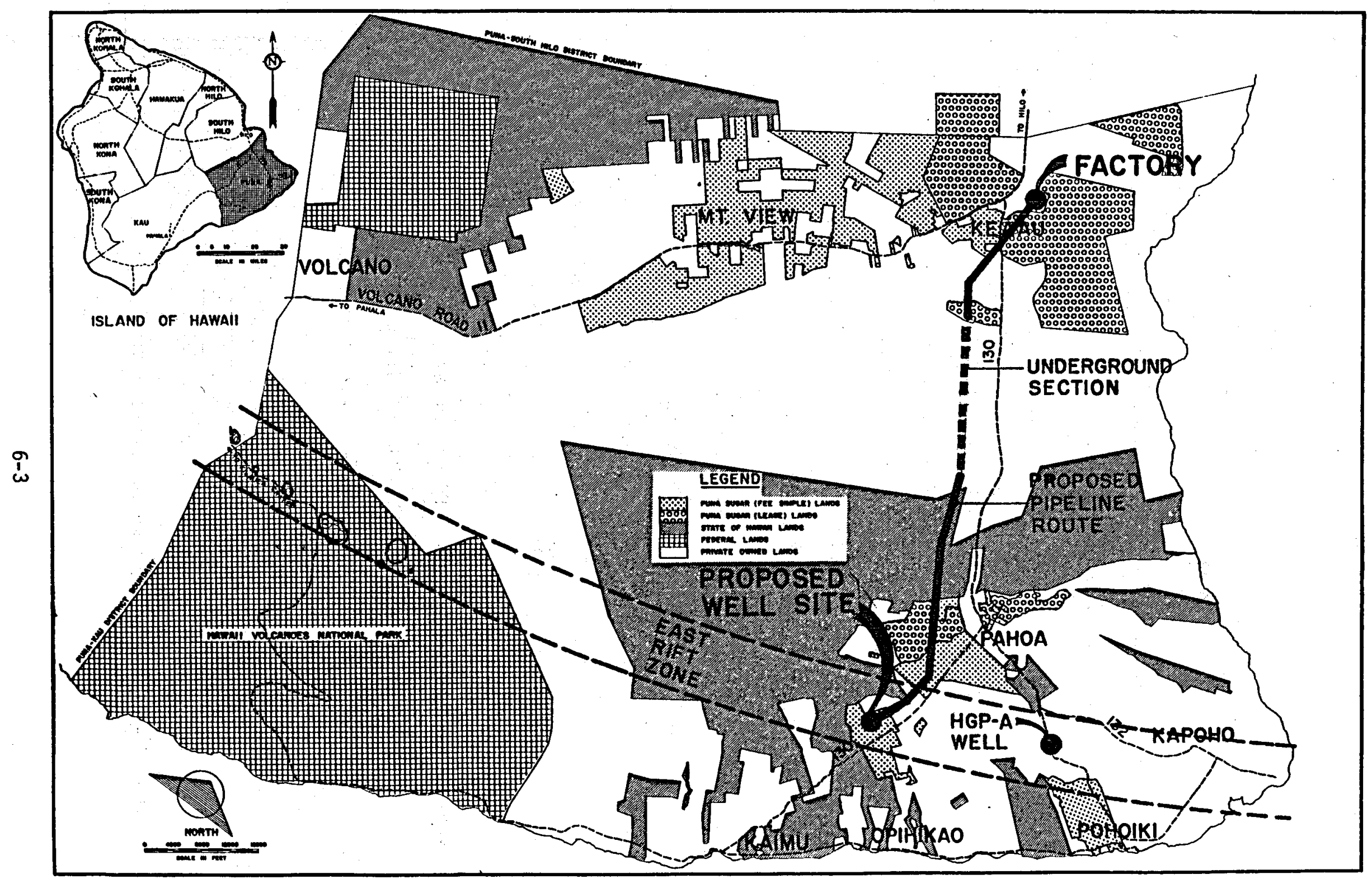

Figure 6-2

Proposed Project Site 
certain amounts of odorous $\mathrm{H}_{2} \mathrm{~S}$ gas will certainly escape into the atmosphere. Besides a concern for geothermal toxicant contamination of the cane juice then, a real concern for environmental degradation led the investigators to propose a binary system wherein geothermal steam produces clean steam in evaporators. Such an arrangement virtually precludes contamination possibilities.

The basis of compensating income for the cash expenditure requirements of the project is the substitution of geothermal steam for bagasse fired steam in process uses. The bagasse fired steam can then be used for increased electrical power generation and sales to HELCO.

\subsection{WELLSITE FACILITIES}

The origin of geothermal resources in Hawaii is magmatic heat. As such, the immediate specific interest has been in areas associated with the rift zones of the Hawaiian volcanoes. These are generally narrow corridors extending radially from the summit calderas of each volcano. Figure 6-3 indicates the five mountain masses that make up the Island of Hawaii and their associated rift zones. As can be seen from the illustration, the East Rift Zones of both Kilauea and Mauna Kea bracket the Puna Sugar factory, and the Northeast Rift Zone of Mauna Kea also approaches the factory. However, there are no known rifts close to the factory site itself.

Since the costs associated with well development are an appreciable percentage of a geothermal system, and there were no readily available hydrothermal resource data at the factory site, initial work was directed toward generic well inputs at several assumed downhole temperatures. In 


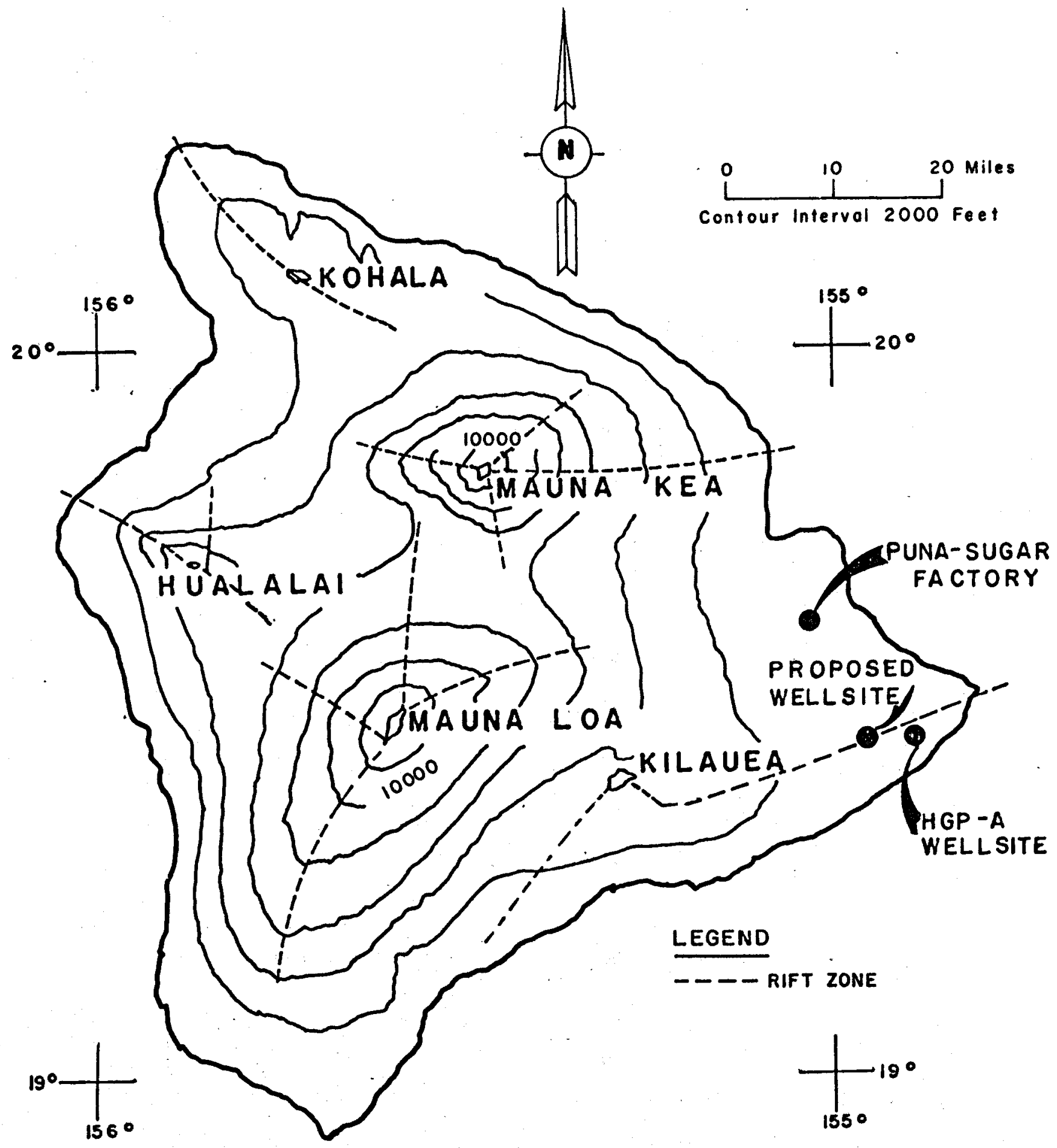

Figure 6-3

Volcanoes and Rift Zones of the Island of Hawaii 
conjunction with Rogers Engineering Company and David Elliott of Jet Propulsion Laboratory, several capacity relationships were developed using parameters associated with the HGP-A well. These relationships of well head pressure versus flow at temperatures of $300^{\circ} \mathrm{F}, 400^{\circ} \mathrm{F}, 500^{\circ} \mathrm{F}$ and $600^{\circ} \mathrm{F}$ have previously been published in the second quarterly report of this series.

Evaluation of the pressure-capacity relationships immediately indicated that any resource with less than a $400^{\circ} \mathrm{F}$ downhole temperature was not of economical use to sugar cane processing. It is not until a $500^{\circ} \mathrm{F}$ downhole temperature is reached that it becomes apparently feasible to consider large scale utilization of geothermal resources at the Puna Sugar factory. With a downhole temperature of $500^{\circ} \mathrm{F}$, flashing at a well head pressure of 160 psig will produce about 55,000 pounds steam per hour per we 11 .

At this point, the probability of a $500^{\circ} \mathrm{F}$ resource in the factory area was questioned by study team members. Since the factory is located some distance from any known rift zone, and since any state funded surface exploratory work was not likely to be completed within the time frame of this study, the volcanically active East Rift Zone of Kilauea was considered for the hydrothermal resource.

\subsubsection{Well Site}

After evaluation of the reported data in the East Rift Zone, a well site was selected. Section 4 discusses the geophysical process which in part led to the specific recommended site shown in Figures 6-4 through 6-6. Fumaroles can be seen in the upper central section of Figure 6-5 and the lower left portion of Figure 6-6, near the proposed well site. Several 


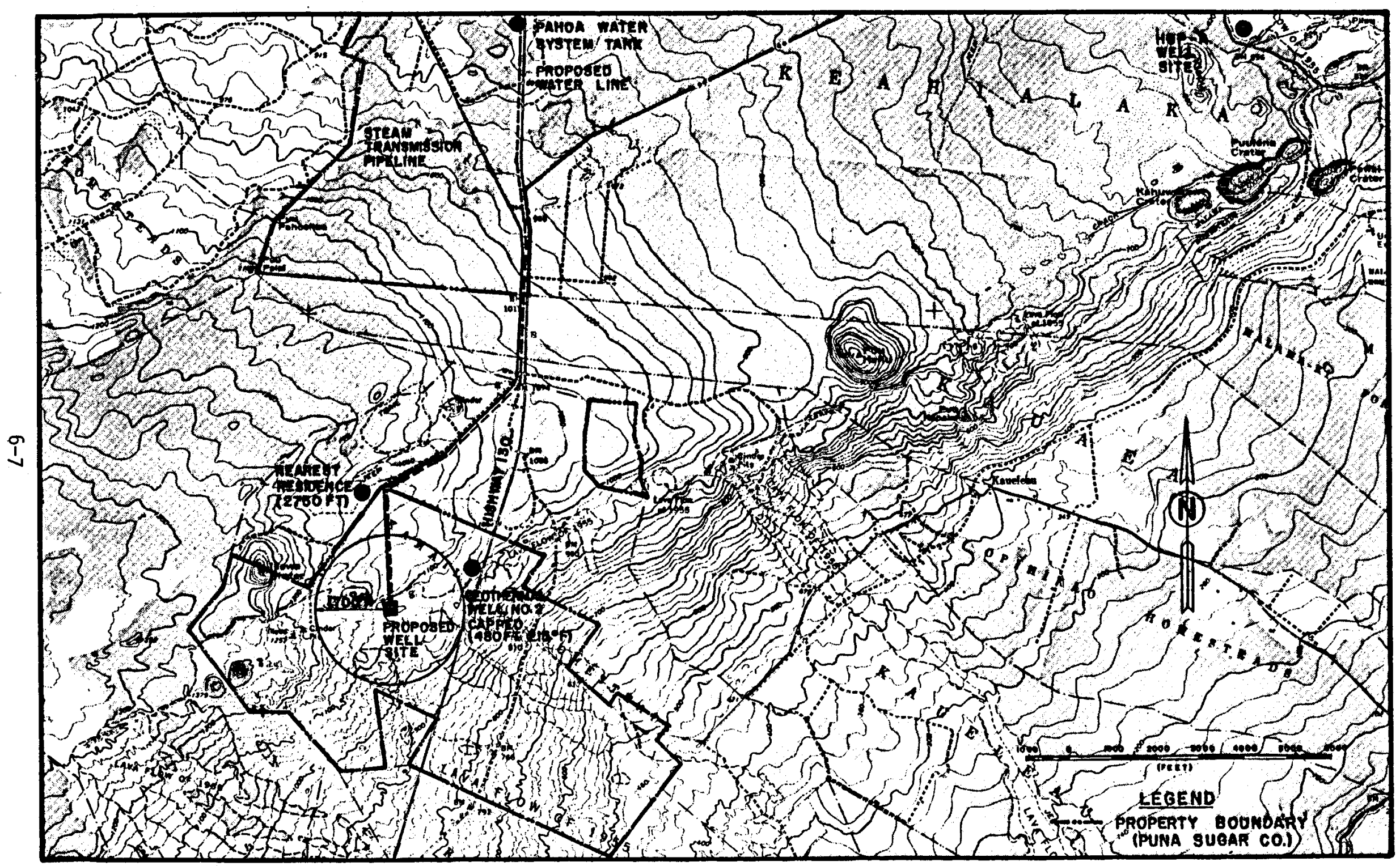

FIGURE $6-4$

PROPOSED WELL SITE AREA 


\section{HGP-A WELL SITE}

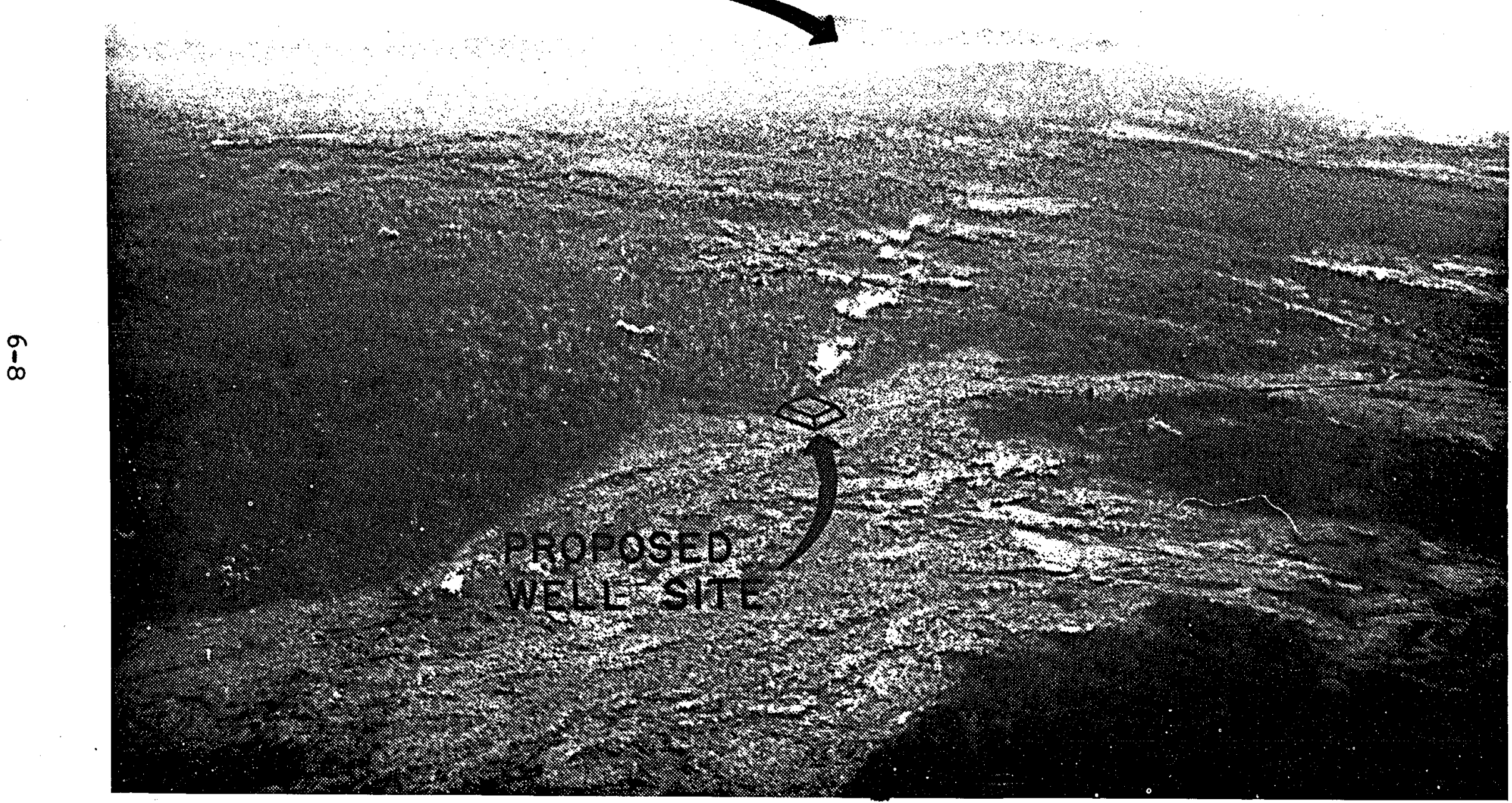

H'igure 6-5

NORTHEAST AERIAL VIEW OF PROPOSED WELI SITE

r 
आ

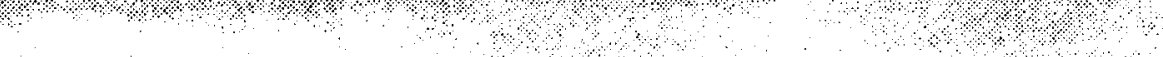
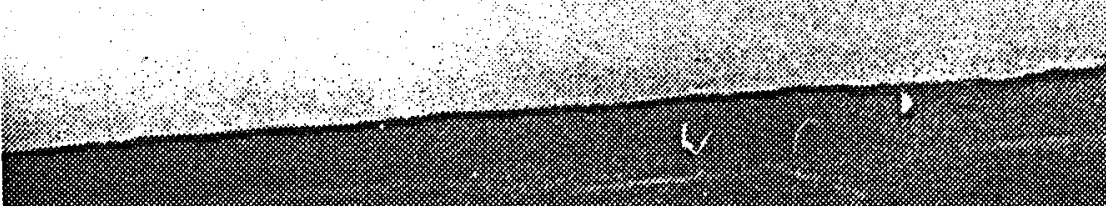

in

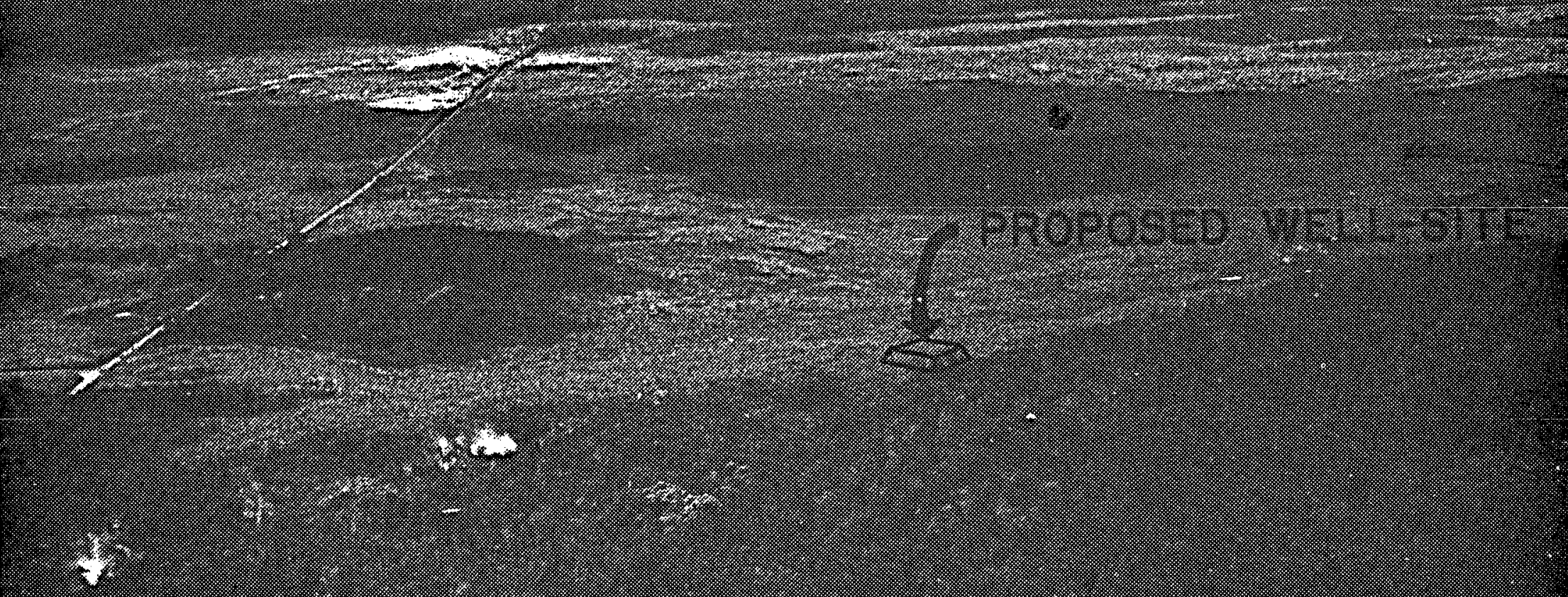

\section{Figure 6-6}


other factors, however, were involved in this selection.

- The total parcel consists of approximately 1100 acres. Although it is bisected by State Highway 130 , it is large enough to accommodate at least the four production wells and one injection well that will be required.

- The surface area of the entire parcel is owned in fee by Puna Sugar, although mineral rights are reserved for the State of Hawaii.

- The topography is relatively flat, reducing site preparation a costs. Also, the flatness will reduce the probability of lava inundation, if appropriate design standards are followed.

- The general wind direction is to the west-south-west, away from inhabited areas, which would reduce objections from any possible stray $\mathrm{H}_{2} \mathrm{~S}$ emission.

- State Highway 130 affords easy and ready access to the well site if needed.

- Electric power is available from the Highway 130 utility easement, should emergency conditions at the well require it.

Figure $6-7$ is a plan view of the well site facilities while Figure $6-8$ is a perspective relationship of the equipment components. The complex grade elevation is raised 20 feet about the surrounding area to divert lava from encroaching into the well site area. No attempt is made, however, to protect the facility from dịect lava bombardment.

Around the periphery of the raised area and surrounding the well site equipment, is a security fence. The specific equipment within this fenced area are discussed individually in the following subsections. 


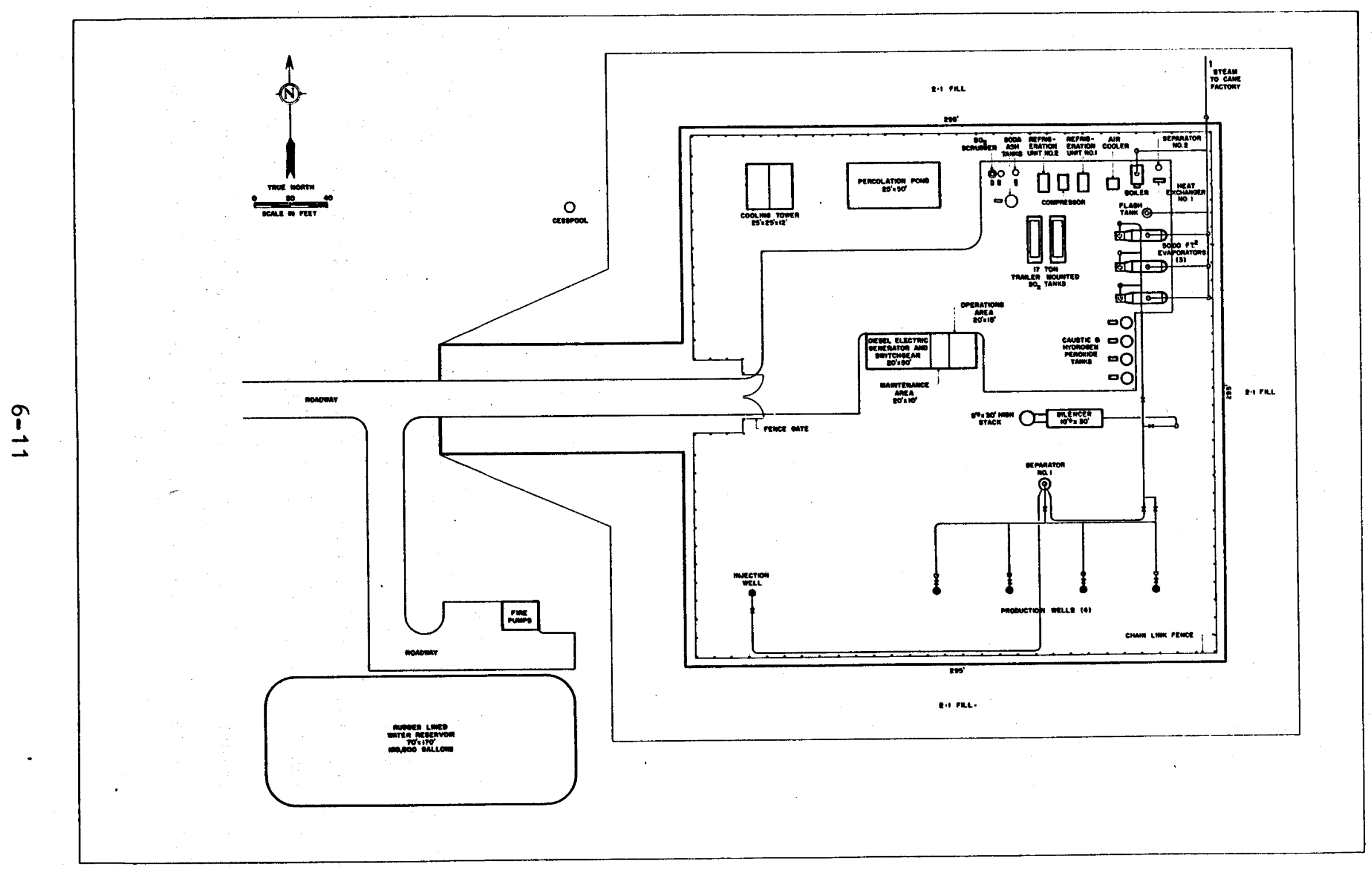

Figure 6-7

IAYOUT OF THE PROPOSED WELI SITE FACILITIES 


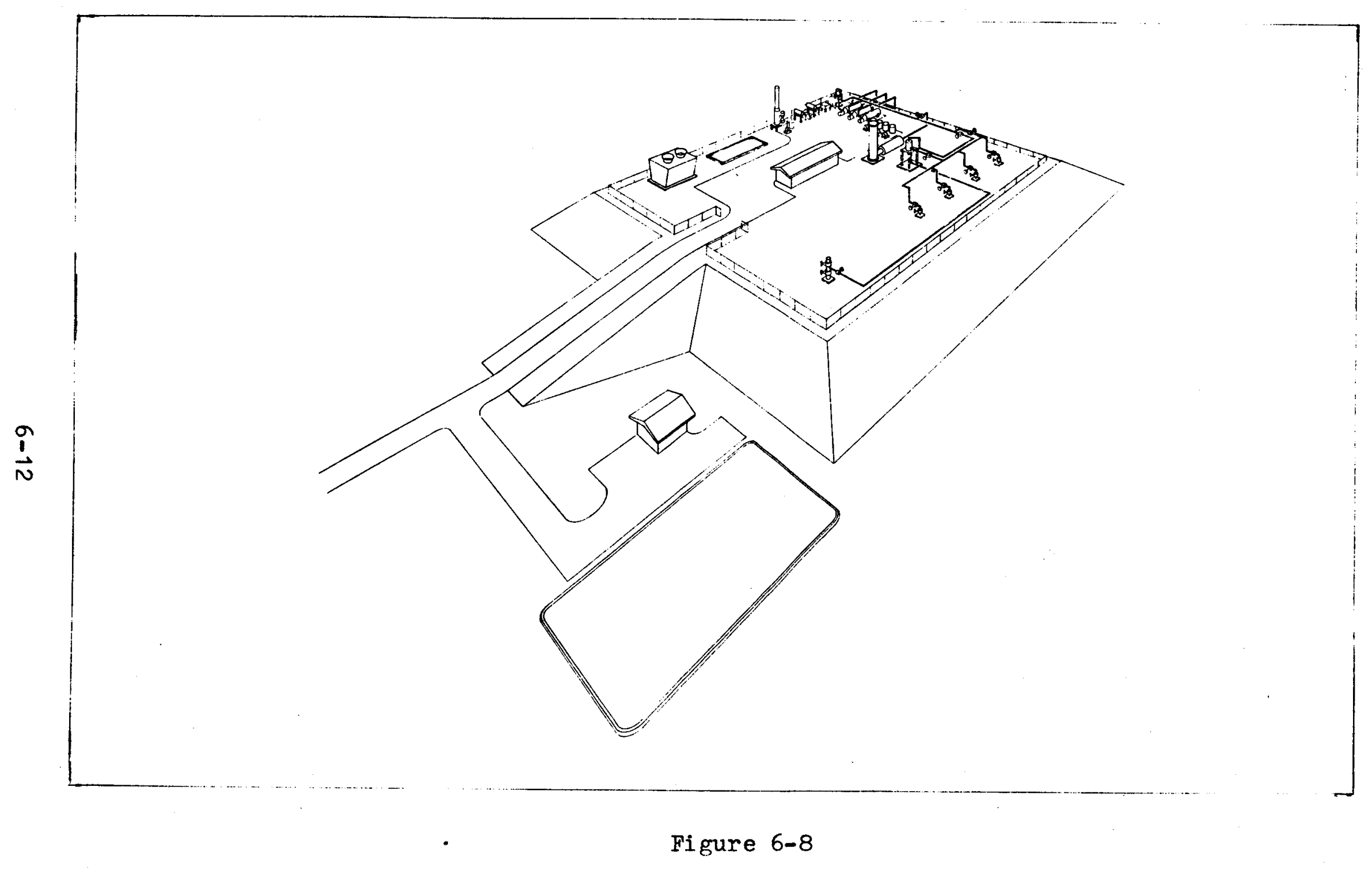

PERSEPECTIVE VIEW OF THE WELL SITE FACILITIES

r 


\subsubsection{Production Wells and Characteristics}

While the exploratory work has to a large extent been completed for the well site, deep exploratory drilling has not yet been attempted. However, due to the proximity of the HGP-A well and the similarity of survey data for both sites, the HGP-A data forms the basis of well characteristics for this study.

Table 6-1 indicates the HGP-A we11 flow property characteristics. The pressure and temperature relationship at the proposed well site is assumed to follow typical HGP-A flashing data. However, the capacity characteristics are more difficult to realize as the HGP-A well flow rates have increased with each succeeding well flashing. Two explanations have been offered for this phenomenon. Hydrothermal stresses may be fracturing the rock strata as the well is flashed, creating greater permeability. The other hypothesis offered claims the well suffered skin damage during its construction period. The drill mud that caked in the well bore is effectively blinding the substrata. With each well flashing, the mud is dislodging, freeing the rock interstices of the obstruction.

In any case, mass flows have increased $30 \%$ from initial flashings to the 1000 hour flashing of January, 1977. Most reported flow data is based on this latter flashing, but a subsequent test produced flows over $5 \%$ greater than those of January, 1977.

What the ultimate capacity of the HGP-A well will be is pure conjecture. Various eventual we 11 capacity guesses ranging from $150 \%$ to $200 \%$ of the January, 1977 reported data have been made. With four production wells in the system, the maximum well flow rate will be about $110 \%$ of the HGP-A 
TABLE 6-1

BGP-A WELL FLOW DATA

\begin{tabular}{|c|c|c|c|c|c|}
\hline $\begin{array}{l}\text { ORIFICE } \\
\text { SIZE } \\
\text { (INCHES) }\end{array}$ & $\begin{array}{l}\text { TOTAL MASS } \\
\text { FLOW RATE } \\
(K \quad L B / H R)\end{array}$ & $\begin{array}{c}\text { STEAM } \\
\text { FLOW RATE } \\
\text { (K K LB/HR) }\end{array}$ & $\begin{array}{l}\text { STEAM } \\
\text { QUALITY } \\
(\%)\end{array}$ & $\begin{array}{l}\text { WELLHEAD } \\
\text { PRESSURE } \\
\text { (PSIG) }\end{array}$ & $\begin{array}{c}\text { WELLLEAD } \\
\text { TEMP. } \\
\left(O_{F}\right)\end{array}$ \\
\hline 8 & 101 & 64 & 64 & 51 & 295 \\
\hline 6 & 99 & 65 & 66 & 54 & 300 \\
\hline 4 & 93 & 57 & 64 & 100 & 338 \\
\hline 3 & 89 & 54 & 60 & 165 & 372 \\
\hline $2-1 / 2$ & 84 & 48 & 57 & 237 & 401 \\
\hline 2 & 81 & 43 & 53 & 293 & 419 \\
\hline $1-3 / 4$ & 76 & 39 & 52 & 375 & 439 \\
\hline
\end{tabular}


well flow data. A $10 \%$ factor appears reasonable enough especially in view of the fact that the HGP-A well has had a history of rising flow rates and that the subsequent flashing has already produced a $5 \%$ increase in flow. A total well flow of 365,000 pounds per hour of two-phase flow is expected as indicated in the flow diagram of Figure 6-9.

Al1 four production wells are assumed to be clustered at a single surface stand. Subsurface, each hole is directionally drilled so that downhole locations are sufficiently separated to produce minimal interactive effects. The single cluster concept for production well heads was selected primarily because of anticipated problems associated with surface transportation of two-phase flows and the collection of incondensible gases.

\section{2:3. Silencer and Separator Stock}

During the initial well purging, the liquid dominated stream from the wells will be directed to a silencer and separator. Noise levels will be mitigated by both the silencer and stack to levels that conform to OSHA standards for industrial type facilities. The total mass flow will be treated with dosages of caustic and hydrogen peroxide, reducing stack emissions of hydrogen sulfide to acceptable limits. Without an absorption tower, the treatment dosages required will exceed stoichiometric quantities, but this expedient is economic for the short durations the silencer is operating.

\section{-6.2.4 Separator}

The two-phase flows from each of the four well heads are throttled into a single 54-inch diameter separator located at the well site. Care must be taken to install a high efficiency separator, as contaminants exist in the 


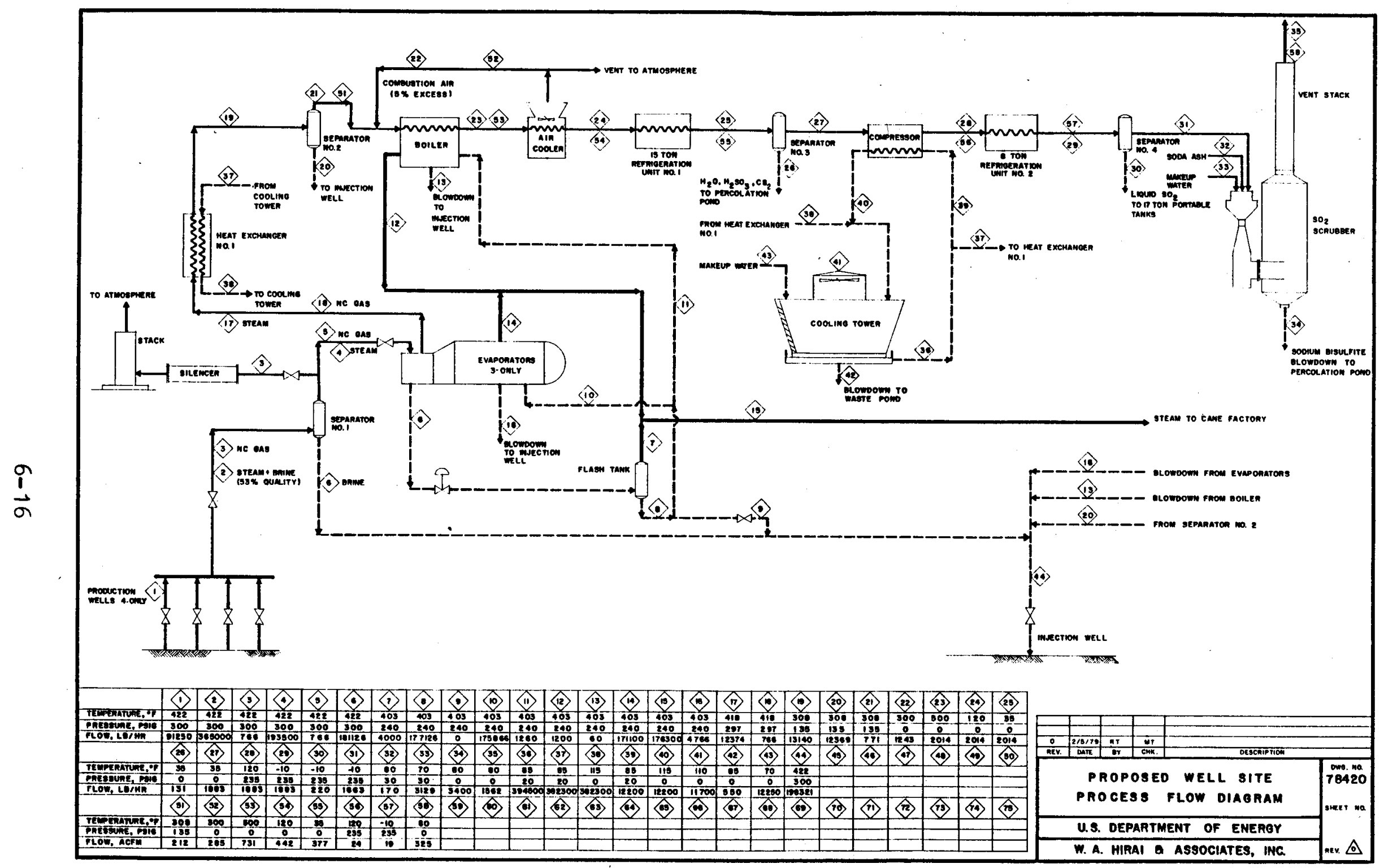

Figure 6-9 
separated steam, entrained with the liquid carryover. The separated steam is delivered to the three well site evaporators, while the brines are injected back into the substrata. Steam flow leaving the separator is expected to be 193,500 pounds per hour.

Table 6-2 indicates the reported HGP-A geochemical data. It is expected that the dissolved solid concentrations in the liquid carryover following separation will remain approximately constant, with the total dissolved solids being a direct function of the separation efficiency. Trace amounts of heavy metals were also reported from the HGP-A well flows, but these are relatively non-volatile, and again total quantities are expected to be a function of separator efficiency.

\subsubsection{Brine Disposal}

All brine streams from the separator will go directly to a single well for subsurface injection. The injection well head itself will be located within the well site complex. Subsurface, the bore will be directionally drilled such that the downhole location is far enough from the production wells to cause only minimal effects on the resource production wells. A casing and cementing schedule will ensure that any ground water aquifer remains pristine.

HGP-A well injection data indicates that with a surface pressure of 300 psig, the 181,100 pounds of brine per hour need not be boosted by a pump. Therefore, the brines will pass directly from the separator outlet to the injection well head.

A significant problem in other geothermal producing areas is precipitation and scaling, primarily from carbonates and silica. This is not expected 
TABLE 6-2

HGP-A GEOCHEMICAL SUMMARY

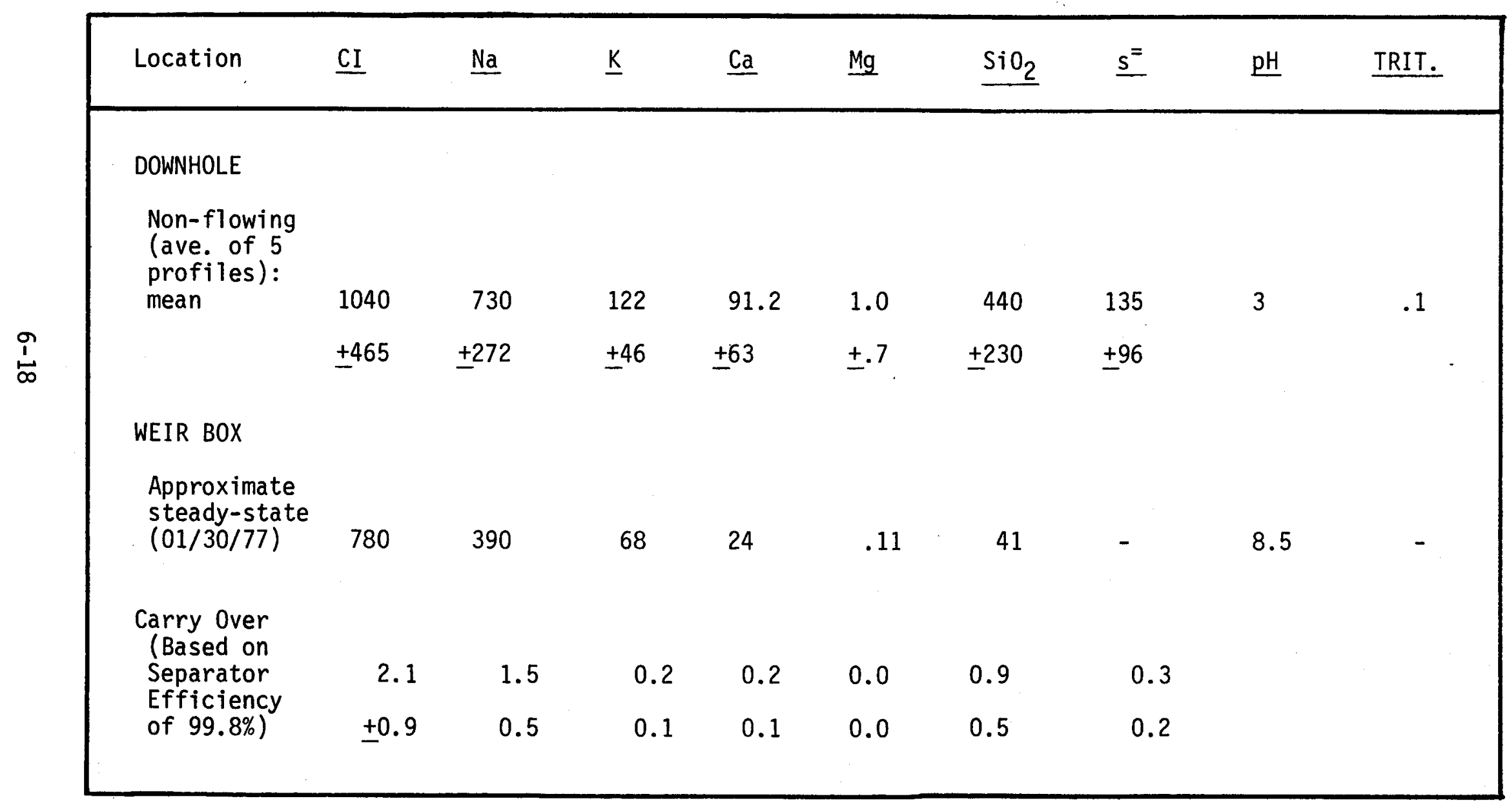

Note: All concentrations in $\mathrm{mg} / \mathrm{l}$ of total discharge 
to be a major source of concern here for several reasons.

- The geothermal fluids at HGP-A are remarkably clean as evidenced in the data of Table 6-2.

- There are virtually no carbonates and the concern is fundamentally limited to silica.

- Precipitation rates are an inverse function of temperature, and the temperatures are kept elevated at the well site.

- The precipitation process requires reaction time, but the brines which transport nearly all the silica and metals are being reinjected seconds after passing through the production well heads.

\subsubsection{Evaporators}

Three kettle type evaporators accept all the geothermal steam from the separator at 300 psig. Each $38^{\prime \prime} \times 58^{\prime \prime} \times 240^{\prime \prime}$ evaporator contains 5,026 square feet of heating surface in a 20 foot stainless steel tube bundle. Although a single evaporator is less expensive, two reasons favored a multiple unit evaporator station. Removal of a single large tube bundle for cleansing is unwieldy and difficult to handle. But the second reason, reliability, is perhaps more important. Tube leakage or any other evaporator malfunction would force the entire geothermal system to shutdown in a single evaporator arrangement. A three evaporator arrangement will keep at least two-thirds of the production on line. Clearly, prudent engineering dictates a multiple unit evaporator station.

The geothermal condensate formed in the evaporator is used as feedwater to produce 171,100 pounds per hour of 240 psig clean steam in the same evaporator, and that steam is transmitted to the Puna Sugar factory. The 
condensate is relatively contaminant free, and certainly superior to basal groundwater in the area. However, very small traces of hydrogen sulfide and carbon dioxide remain. Of the two gases, hydrogen sulfide poses a more significant problem, although still a minor one.

Work has been progressing in other geothermal areas on separation or partitioning efficiency of hydrogen sulfide in heat exchangers. These evaluations predict up to $98 \%$ of the hydrogen sulfide will be in the gas phase, or as little at $2 \%$ will be dissolved in the condensate. However, these studies have been based on the low temperature and vacuum conditions of a turbogenerator condenser. Since the solubility of hydrogen sulfide is a function of temperature, pressure, and $\mathrm{pH}$, it can be greatly different in the case of evaporator condensates. In fact, a review and extrapolation of available solubility data indicates the higher temperatures have a disproportionately greater influence on solubility than increased pressure. The net result is that solubility of hydrogen sulfide is approximately 20 times less in the evaporator condensates than the turbogenerator condensates. To this, must be added the influence of lower $\mathrm{pH}$, which further reduces hydrogen sulfide solubility.

The effects of hydrogen sulfide and carbon dioxide then can probably be easily controlled through careful $\mathrm{pH}$ adjustment of the geothermal steam and condensate. Combinations of sulfuric acid, caustic, neutralizing amines, filming amines, oxygen scavengers, and antiform conditioners added to the steam and condensate flows should develop acceptable steam quality in the transmission pipeline.

Chemical concentrations in the evaporator will increase over time, and the blowdowns necessary to control concentration are pumped to the injection 
well for disposal. These blowdowns will be approximately 4,800 pounds per hour.

\subsubsection{Hydrogen Sulfide Conversion}

The second stream exiting the evaporators from the geothermal steam side contains the noncondensible gases. A summary of the gas analysis reported for HGP-A is given in Table 6-3 and is used as the basis for process evaluation.

Experience at the HGP-A well site has determined that the major problem with gas emission is one of a nuisance situation related to hydrogen sulfide. Levels of hydrogen sulfide exceed the threshold of human detection, and the odoriferous presence of the gas is a source of irritation to the nearby residences when the well is flashing. At no time, however, does any gas concentration approach levels hazardous to health, even within 30 feet of the well discharge. There are no applicable State nuisance standards for $\mathrm{H}_{2} \mathrm{~S}$, al though industrial health requirements of relatively high allowable concentration levels apply, as illustrated in Table 6-4. The same table also indicates relevant $\mathrm{SO}_{2}$ standards, $\mathrm{SO}_{2}$ being the principal oxidation product of hydrogen sulfide.

In addition to a nominal $\mathrm{H}_{2} \mathrm{~S}$ emission level, the gas release mechanism at HGP-A is entirely different from that at the proposed well site. Gases at HGP-A are subjected to a violent decompression and expansion process which allows considerable opportunities for toxicant entrainment and discharge to the atmosphere. This is not true with the proposed well site facility which has a controlled separation of the two-phase flow in the separator, followed by condensation in the evaporators. Noncondensible gases are bled out of 
TABLE 6-3

SUMMARY OF GAS ANALYSES FOR HGP-A

\begin{tabular}{|c|c|c|c|c|c|c|c|c|c|}
\hline $\begin{array}{l}\text { Date/Type of } \\
\text { Sample }\end{array}$ & $\begin{array}{l}\text { Sampling } \\
\text { Pressure } \\
\text { (psi) }\end{array}$ & $\begin{array}{l}\text { Temp. } \\
\text { (OC) }\end{array}$ & $\begin{array}{l}\text { Total Gas } \\
\text { (mg/kg of } \\
\text { discharge) }\end{array}$ & \multicolumn{4}{|c|}{$\begin{array}{c}\text { Composition } \\
(W t \%)\end{array}$} & \multicolumn{2}{|c|}{ Mole Ratio } \\
\hline $\begin{array}{l}\text { 1/29/77; Total } \\
\text { Condensate from } \\
\text { Cooled Cyclone } \\
\text { Separator }\end{array}$ & 50 & 30 & $991 *$ & 72 & 10 & 18 & 0.1 & 5.5 & 19.5 \\
\hline $\begin{array}{l}\text { 4/5/77; Steam from } \\
\text { Cyclone Separator }\end{array}$ & 165 & 185 & 1604 & 59 & 20 & 21 & 0.5 & 2.3 & 3.0 \\
\hline $\begin{array}{l}5 / 9 / 77 \text {; Steam from } \\
\text { Cyclone Separator }\end{array}$ & $\begin{array}{r}167 \\
40\end{array}$ & $\begin{array}{l}188 \\
188\end{array}$ & $\begin{array}{l}1912 \\
2697\end{array}$ & $\begin{array}{l}57 \\
65\end{array}$ & $\begin{array}{l}21 \\
24\end{array}$ & $\begin{array}{l}21 \\
10\end{array}$ & $\begin{array}{l}1 \\
0.4\end{array}$ & $\begin{array}{l}2.1 \\
2.1\end{array}$ & $\begin{array}{l}2.4 \\
1.8\end{array}$ \\
\hline $\begin{array}{l}\text { 7/19/77; Steam from } \\
\text { Cyclone Separator }\end{array}$ & 25 & 180 & 1337 & 71 & 18 & 11 & 0.5 & 3.0 & 1.6 \\
\hline $\begin{array}{l}\text { Best estimate for } \\
\text { total gas content } \\
\text { of HGP-A }\end{array}$ & - & 180 & 2100 & 60.3 & 21.7 & 17.3 & 0.6 & 2.1 & 2.1 \\
\hline
\end{tabular}

*The 29 Jan. 1977 values most closely reflect the composition of the HGP-A stack emissions. 
TABLE 6-4

STANDARDS FOR $\mathrm{H}_{2} \mathrm{~S}$ AND $\mathrm{SO}_{2}$

\begin{tabular}{|c|c|c|c|c|}
\hline \multirow{2}{*}{ 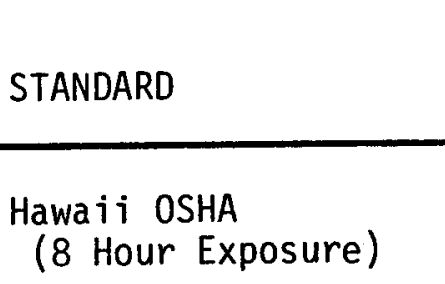 } & \multicolumn{2}{|c|}{$(\mathrm{ppm})^{\mathrm{H}_{2} \mathrm{~S}}\left(\mathrm{ug} / \mathrm{M}^{3}\right)$} & \multicolumn{2}{|c|}{$(\mathrm{ppm}){ }^{\mathrm{S} 0_{2}}\left(\mathrm{ug} / \mathrm{m}^{3}\right)$} \\
\hline & 10 & 15,000 & 5 & 13,000 \\
\hline $\begin{array}{l}\text { Hawai i OSHA } \\
\text { (5 Minute Exposure) }\end{array}$ & 20 & - & 20 & - \\
\hline $\begin{array}{l}\text { Alert Level } \\
\text { (24 Hour Average) }\end{array}$ & - & - & 0.3 & - \\
\hline $\begin{array}{l}\text { Identification } \\
\text { ( } 50 \% \text { of Population) }\end{array}$ & 0.030 & - & - & - \\
\hline $\begin{array}{l}\text { Identification } \\
\text { ( } 0 \% \text { of Population) }\end{array}$ & 0.010 & - & - & - \\
\hline \multicolumn{5}{|l|}{ Ambient Air Quality } \\
\hline 3 hour & - & - & - & 400 \\
\hline 24 hour & - & - & - & 80 \\
\hline Annual & - & - & - & 20 \\
\hline
\end{tabular}


the evaporators in a much more stable environment. Very little carryover is expected through the entire process.

Finally, the well site will be at least 1700 feet from the closest property boundary and more than 2750 feet from the nearest residence. Therefore, the circumstances make the proposed well site facility much more compatible with rational mitigating measures than does the HGP-A site.

Evaluation of the gas analysis and process requirements shows that approximately 900 tons of $\mathrm{H}_{2} \mathrm{~S}$ can be produced annually at the well site. Calculations utilizing an atmospheric dispersal model indicate that ground level concentrations (GLC) beyond the property boundary will exceed minimum human detection levels. Hydrogen sulfide treatment is therefore advisable.

Several methods of treating the hydrogen sulfide are available, including absorption-desorption processes producing sulfur dioxide $\left(\mathrm{SO}_{2}\right)$ and systems generating elemental sulfur, such as the "Claus" and Stretford methods. Since the Puna Sugar factory already utilizes liquid $\mathrm{SO}_{2}$ in its cane juice process, and several other sugar factories are considering using $\mathrm{SO}_{2}$, the decision was made to incorporate a method producing liquid $\mathrm{SO}_{2}$. The byproduct can then be used in the cane processing, with the excess being sold to other factories. Here, it is not essential to have an efficient recovery system, and the main emphasis was to select a method that minimized capital costs.

The specific recovery method selected is incineration followed by refrigeration and compression cycles to produce a liquid $\mathrm{SO}_{2}$ byproduct. Effluent gases are later scrubbed before release into the atmosphere. Sulfur dioxide 
discharges from the scrubber are then well within ambient air quality standards shown in Table 6-4. Figure 6-9 indicates the flow sequence of the hydrogen sulfide conversion process.

Noncondensible Gas Cooler. A mixture of noncondensible gases and steam is vented from the evaporators. The steam fraction must be condensed prior to incineration, and for this purpose, it passes through a shell and tube condenser. Cooling water is supplied to the condenser from a cooling tower.

Noncondensible Gas Separator. Following the condensation process, the condensates are separated from the gases and pumped back to the injection well for disposal.

Boiler. The noncondensible gases leaving the separator are then incinerated in a 40HP Scotch Marine boiler, with the addition of combustion air. Feedwater is supplied from evaporator condensates to produce 1200 pounds of steam per hour at $240 \mathrm{psig.} \mathrm{This} \mathrm{steam} \mathrm{then} \mathrm{joins} \mathrm{the} \mathrm{clean} \mathrm{steam} \mathrm{output}$ of the three evaporators for transmission to the Puna Sugar factory. Blowdowns are discharged to surface ponds where percolation and evaporation dispose of the effluents. Combustion gases are cooled within the boiler to $500^{\circ} \mathrm{F}$, and are further cooled to $120^{\circ} \mathrm{F}$ by air coolers.

Refrigeration Unit No. 1. The cooled products of combustion are further cooled to $35^{\circ} \mathrm{F}$ in a 15 ton refrigeration unit. Condensates are separated before the gases pass to the compressor.

Compressor. The water cooled compressor raises the gases to $235 \mathrm{psig}$ while simultaneously limiting gas temperature rise to $120^{\circ} \mathrm{F}$. Water from 
the cooling tower is supplied to the gas compressor to cool the gases.

Refrigeration Unit No.2. Following compression, the gases are once again refrigerated using an eight ton refrigeration unit. In the process of attaining $-10^{\circ} \mathrm{F}$ temperature, the $\mathrm{SO}_{2}$ gas liquifies. The liquid $\mathrm{SO}_{2}$ is piped to and stored in 17 ton portable tanks for later transport to the Puna Sugar process plant or for sale to other sugar factories.

Approximately two-thirds of the $\mathrm{SO}_{2}$ or 900 tons annually, can be extracted in this manner, with the remaining fraction being processed in a scrubber. The liquid sulfur dioxide product does contain nearly $3 \%$ water and it will be necessary to utilize stainless steel tanks for its transport. However, this moisture does not affect the cane juice processing.

Waste Gas Scrubber. With the addition of soda ash and water, the waste gas $\mathrm{SO}_{2}$ level can be reduced to acceptable levels in a scrubber unit. Final scrubber treatment of the effluent gas will reduce the $\mathrm{SO}_{2}$ levels to approximately $0.5 \%$ of the sulfur dioxide produced. Discharge of this gas from the scrubber will be well within the allowable $\mathrm{SO}_{2}$ concentration levels for ambient air. Blowdown from the system is primarily sodium bisulfite which will be directed to the settling ponds for disposal.

\subsubsection{Water Development}

Water is needed at the well site for several purposes, the main use being cooling water makeup. Flow rates of approximately $30 \mathrm{gpm}$ from the Pahoa potable water system is required. This water is pumped through a new pipeline from the Pahoa area water tank, a distance of three miles to the well site. Figure 6-4 traces the water pipeline route from the water tank. 


\subsubsection{Electric Power Supply}

Electric power requirements for the well site facilities center in two separate areas. Power must be available at the Pahoa water tank to pump water to the well site. Since the power consumption is only $3.5 \mathrm{HP}$, and HELCO power lines are located almost immediately overhead, it was elected to use HELCO power at the tank for pumping purposes.

At the well site proper, diesel power generation was determined to be more cost effective than purchased power. As a consequence, a $175 \mathrm{~kW}$ generating set is included for electric power production to meet the demands of the well site facility.

\subsubsection{Other Well Site Facility Options Evaluated}

Water Development. A water well at the geothermal site was considered to provide for the water requirements. Evaluation of the capital and 0 \& $M$ costs favored use of the County potable water system. Factors weighing against a well were:

- The well would probably have to penetrate the basal water lens, requiring a 1200 foot deep well for only about $50 \mathrm{gpm}$ capacity. Because of the depth, the well bore size would have to be disdisproportionately large.

- The water hardness in the East Rift Zone is very high because of the geothermal influence. This raises chemical treatment costs and increases blowdown frequency for the process.

- The Pahoa water system is already operating, with a known well chemistry. Its capacity is adequate to supply all anticipated well site requirements.

Electric Power Supply. An unfortunate reality is that Puna Sugar must pur- 
chase electrical power at the well site at a rate substantially higher than that at which it sells power. Cost analysis determined that it is more economical to generate power at the well site using a diesel electric generator than to purchase power from HFLCO.

\subsection{RESOURCE TRANSMISSIJN}

The geothermal resource in the East Rift Zone must be transported 16 miles to the Puna Sugar factory in Keaau. Technically, the transmission is relatively straightforward and does not appear to present insurmountable problems. Figure 6-2 delineates the proposed pipeline route from the well site to the process plant based on sound engineering design criteria. However, institutional requirements and public reaction may ultimately dictate the specific pipeline routing and configuration.

\subsubsection{Pipeline}

The steel pipe from the well site to Keaau is 20 inches in diameter and of standard wall thickness. It is capable of transporting up to 180,000 pounds steam per hour along its 16 mile length, with an initial pressure of 240 psig at the East Rift. Resistance to the steam flow will cause an 80 psig pressure drop, producing 160 psig steam at the factory.

It is supported on the ground in the usual steam pipe manner, by steel shoes sliding over steel plates anchored in concrete. Expansion joints are located every 500 feet to counteract the effects of thermal expansion. In sections where the pipe must be located below ground level, the pipe is placed in grade elevation concrete trenches with removable concrete covers.

\subsubsection{Thermal Losses}

Due to the length of the pipeline, condensation of some steam will occur 
from radiation and convection heat 1osses. Steam traps are located at spaced intervals along the pipe to collect and discharge this condensate from the pipe.

During the pipeline design phase, thermal calculations were made for several pipe insulation thicknesses. It was assumed that calcium silicate block insulation is used to insulate the pipe with an all-weather aluminum sheet jacketing protecting the insulation.

Table B-1 of Appendix B is a printout of steam loses versus insulation thickness for the 16 mile pipe run. Thinner insulation reduces installation costs, but increases heat losses. Additional steam must be supplied by the wells which may in turn force larger pipe sizes. After evaluation of total system costs, a five inch thick pipe insulation was selected.

Steam losses in the transmission pipe will total 14,100 pounds per hour. Initial 240 psig steam flow at the well site is then 176,300 pounds per hour to supply 162,200 pounds per hour of 160 psig steam at the Keaau process plant.

\subsubsection{Pipeline Corridor}

The proposed pipeline generally parallels State Highway 130 taking a northerly tact from the well site to Keaau. However, at no time will the pipeline encroach longitudinally into the highway right-of-way.

The pipe can be positioned at ground level for approximately 11 miles of the total 16 mile route. Located within the remining five miles is a band of housing subdivisions that cannot be traversed with a ground level pipeline. Well over 150 individual lots must be crossed. Fortunately, many roads parallel the general direction of the pipeline, and the pipe can be 
located at the shoulder of any of these roads in grade level covered concrete trenches.

\subsubsection{Pipeline Easements}

For the length of the pipeline, few separate easements appear to be necessary. The portions of the pipeline at ground level pass through land owned by Puna Sugar Company, Bishop Estate, the Roman Catholic Church, Shipman Estate, the State of Hawaii, and two small parcel owners. Some of the lands are already leased by Puna Sugar for sugar cane production. A general consensus is that the large tract owners, including the State, have an economic interest in the development of geothermal resources, and that easements can eventually be negotiated.

The five mile trenched section routed through subdivisions will require easement negotiations with two community associations in addition to two individual lot owners. Since the roads are privately owned and are maintained by lot owner subscription to a road maintenance fund, it appears in the interest of the community association to negotiate easement leases, which can lower the maintenance subscription fees.

The individual lot owners are located on either end of the trenched section. The exact route of the pipeline will have to come after easements have been negotiated with these lot owners. Easements through any of 20 lots on each end will not affect the pipeline costs significantly.

\subsubsection{Other Resource Transmission Options Evaluated}

Several resource transmission options were evaluated during the course of the study to determine how the resource could best be handled and transmitted from the rift zone to the Puna Sugar factory at Keaau. Transmission 
of the raw untreated geothermal fluids in the liquid state was evaluated initially, but downhole temperature characteristics similar to HGP-A requires a well head pressure in excess of 2000 psig. This makes it impractical to pump the wells and maintain liquid wellhead conditions for brine transmission.

The well flows are then limited to a two phase condition. Transmitting raw geothermal steam was ruled out due to environmental considerations. Also, it is not economical to transmit the raw liquid phase separately since it contains very little usable heat, and much of that is lost in a 16 mile pipeline. The remaining options then centered around binary systems transmitting hot water, second fluids, or clean steam.

Pipeline transport using hot water heated at the well site has certain inherent advantages. It is non-toxic and can extract more of the heat from the geothermal resource than a steam system. It has been reported that hot water piping systems up to 20 kilometers long are operating with minimal temperature losses of about $0.1^{0} \mathrm{C}$ per kilometer. These systems, however, transport liquid at less than $100^{\circ} \mathrm{C}$ and heat losses mount appreciably with higher temperatures.

Another disadvantage of a hot water system is that water has a relatively low heat carrying capacity, as only sensible heat can be transmitted. This fact, coupled with the relatively high temperature and Btu requirements of the factory at 160 psig steam pressure do not favor hot water transmission. For example, should 180 psig saturated hot water arrive at the factory and be flashed to 160 psig steam, only $1 \%$ of the mass flow can be utilized, requiring about a $17,000 \mathrm{gpm}$ pipeline flow to meet the factory $160 \mathrm{psig}$ 
steam requirements. Using a double flash arrangement, with the second flash occurring at the other factory process steam pressure leve1, will produce more $13 \mathrm{psig}$ steam than the factory can utilize. Alternatively, a single flash at 13 psig can be used to produce about $15 \%$ flash steam by mass, but very major process retrofit equipment must be installed before the factory can accept substantial quantities of this steam pressure.

Developing water sources for a hot water system also is a problem. In a well site area where there are no perennial streams, no domestic water, and located more than 1100 feet above any basal ground water, the supply of water of this flow magnitude is questionable. Returning water 16 miles from the factory is also prohibitive. For these reasons, a binary system concept using hot water was abandoned.

A binary system using a second fluid was also investigated. Several fluids are commercially available and were investigated, primarily because of their boiling temperature of over $500^{\circ} \mathrm{F}$. This can result in higher unit sensible heat transmission. These fluids can be heated in a shell and tube heat exchanger at the geothermal well site and piped to another heat exchanger at the Puna Sugar process plant to produce steam.

Initial evaluation of a steam transmission system centered around developing water from a water well near the geothermal well site, since water requirements are substantially less than for the hot water system. Flow rates of approximately $350 \mathrm{gpm}$ are required to meet the steam flow needs. A review of the expected dissolved solids in basal water, however, was discouraging. Water is not available at less than $40 \mathrm{ppm}$ silica, which necessitates excessively 
large chemical requirements and high evaporator blowdowns.

A secondary evaluation was made for a steam transmission system with condensate return from the Puna Sugar factory to the geothermal well site. Since this option would cost more than the system utilizing geothermal steam condensate, it was rejected. One final comment may be appropriate here. The alternative of utilizing condensate return may have found a place were it not for the long transmission requirements. It has the good feature of eliminating the possibility of geothermal contaminant entrainment.

\subsection{FACTORY SITE RETROFIT}

There are surprisingly few modifications that will be necessary at the factory for accepting the large quantities of steam developed from geotherma 1 resources. The Puna Sugar factory operates at three steam pressure levels. Operationally, there is no distinction between steam generated by the factory boiler and clean steam generated by geothermal resources. The externally generated steam enters the 160 psig factory system and is assimilated into the process. Since the pipe transmission distance economically prohibits transport of brines, there is no retrofitting for brines.

\subsubsection{Separator}

Steam from the geothermal evaporators arrives at the factory and passes through a separator to remove moisture. Exiting the separator, the steam is throttled to the required pressure and immediately enters the $160 \mathrm{psig}$ steam sys.tem serving the process requirements. Figures 6-10 through 6-12 indicate steam flows for various conditions.

\subsubsection{Turbogenerator Modifications}

Steam produced by the well site equipment can fulfill process flow require- 


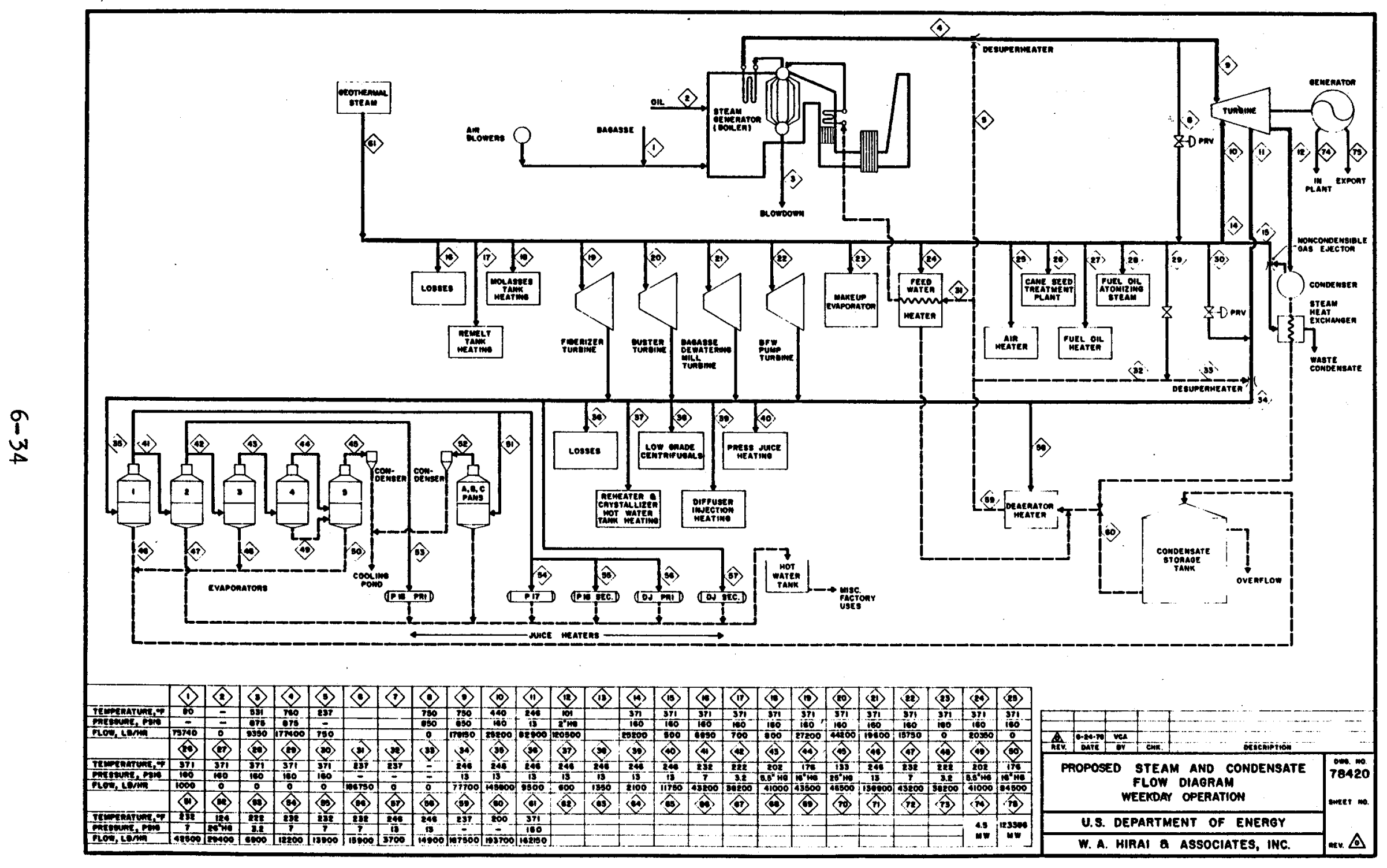

Figure 6-10

PROPOSED STEAM AND CONDENSATE FLOW DIAGRAM

WEEK DAY OPERATION 


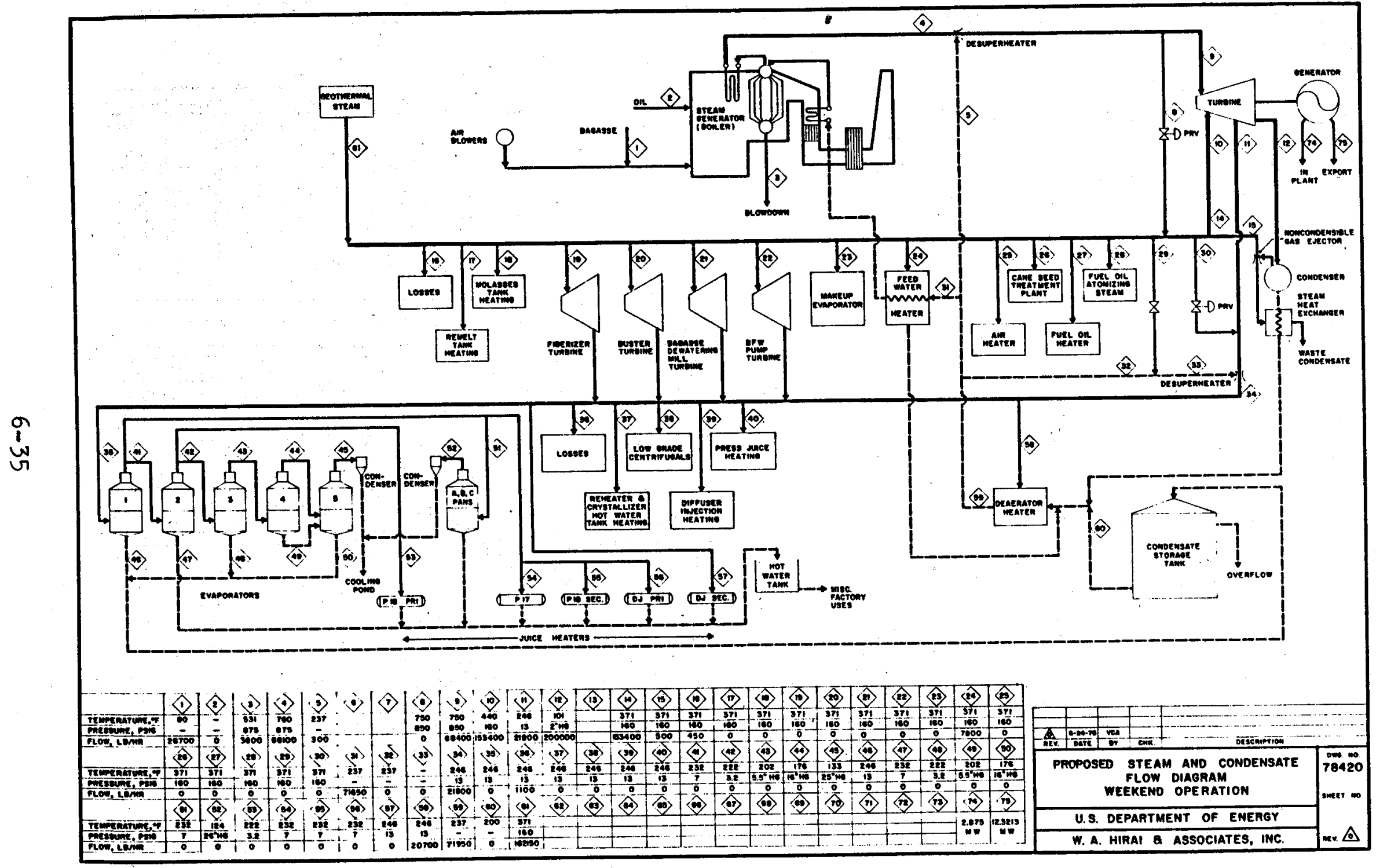

Figure 6-11

PROPOSED STEAM AND CONDENSATE FLOW DIAGRAM WEEK END OPERATION 


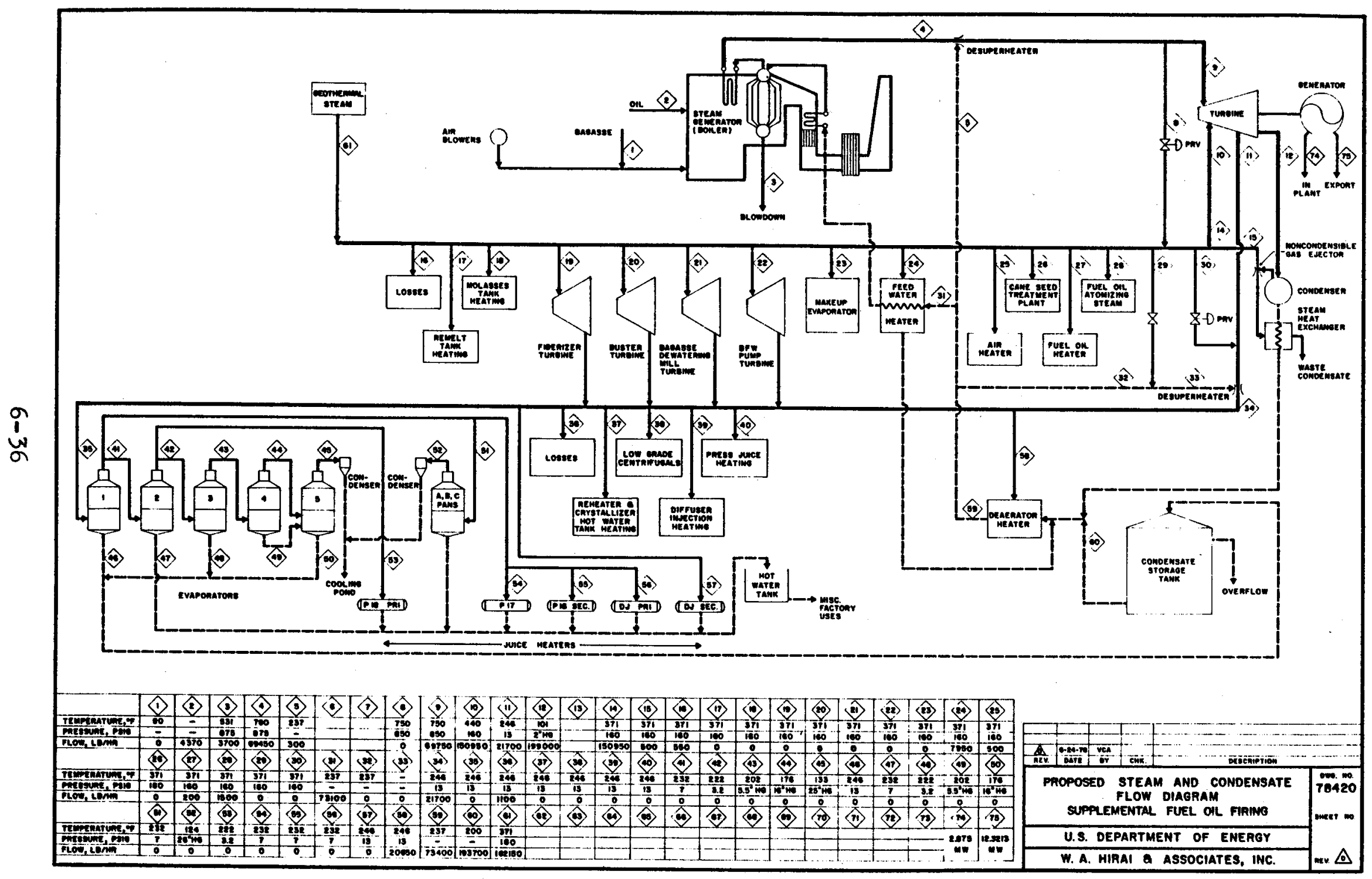

Figure 6-12

PROPOSED STEAM AND CONDENSATE FLOW IIAGRAM SUPPLEMENTAL FUEL OIL FIRING 
ments at the factory. Additionally, it can also supply steam to the 160 psig extraction port of the turbogenerator.

In the present turbogenerator mode of operation, 850 psig steam is generated in the boiler by the firing of fuel oil and bagasse and is directed to the turbogenerator throttle. This steam expands through the turbine with some steam being automatically extracted from the turbine to meet process needs at 160 psig and 13 psig. Any steam remaining in the turbine is exhausted to and condensed in a she11 and tube condenser.

Electricity generated by the turbogenerator supplies factory demands. In addition, certain quantities of electricity are exported and sold to HELCO on a firm, predetermined schedule. Since the turbogenerator and switch gear are not now operating at rated capacity, additional steam can be admitted at 160 psig into what normally is the extraction port, generating a total of $12.32 \mathrm{MW}$ for export sales to HELCO. This revenue, plus the substantial decrease in boiler fuel oil consumption offsets the annual capital and operating costs of the geothermal system.

Some modifications to the turbogenerator are necessary to effect this change. Among these changes are:

- Removal of the ninth stage turbine nozzles and buckets.

- Installation of new 11th stage turbine nozzle diaphragms and buckets.

- Modifications to the governor.

- Installation of a 160 psig admission stop valve.

- Replacement of the existing condenser with one capable of condensing 200,000 pounds steam per hour. 
- Installation of a pressure reducing valve at the 13 psig extraction port, since additional steam flows to the condensing end of the turbine will cause a pressure rise at the extraction port.

\subsubsection{Cooling Water Development and Disposal}

In addition to the three vertical deep wells, and the Maui-type well, two additional $2800 \mathrm{gpm}$ wells must be drilled to meet the new turbogenerator condenser water requirements. These wells will be located near the boiler, in the general vicinity of the present wells, and piped into a common system. With the additional wells, the total condenser water capacity will be $16,400 \mathrm{gpm}$.

Since the cane process rate is not expected to increase, the excess condenser water that is not utilized in process, will be discharged into an existing injection well. Recharge of the basal lens is not expected to upset the ground water temperature, as the aquifer in this area is about 800 feet thick.

\subsubsection{Factory Steam Flows}

Figures 6-10 through 6-12 show schematic arrangements and flows of the factory steam system retrofit for three operating modes. These conditions are:

- Weekday operation during the 46 week process campaign, cane factory operating, boiler and turbogenerator operating.

- Weekend operation during the 46 week process campaign, cane factory not operating, boiler and turbogenerator operating.

- Weekday and weekend operation for the two week period after 
the process campaign, cane factory not operating, boiler and turbogenerator operating.

In all cases, geothermal steam usage is 162,200 pounds per hour and net electrical power export to HELCO is $12.32 \mathrm{MW}$.

Figures 6-10 and 6-11 represent steam flow conditions during the 46 week sugar campaign. In Figure 6-10, the flows depict weekday operations when the cane factory is on-line and there is a demand for substantial quantities of process steam. Bagasse firing produces 177,400 pounds per hour of steam, which when added to the geothermal steam, totals 339,600 pounds steam per hour. Gross electrical production is $16.8 \mathrm{MW}$ while net export is $12.32 \mathrm{MW}$.

On weekends, during the sugar campaign, the factory is shut down for cleaning and minor repairs. Steam consumption is basically for electric power production and bagasse generated boiler steam is reduced to 68,100 pounds per hour. Geothermal steam flow continues to be 162,200 pounds per hour. Total steam usage during campaign weekends then is 230,300 pounds per hour to gross $15.20 \mathrm{MW}$. Net power sales continues at 12.32 MW.

Following the 46 week process campaign, the boiler and turbogenerator must operate without bagasse for two weeks to complete the electrical production year. During this period, 3600 barrels of No. 6 fuel oil is fired in the boiler to produce steam. The 69,500 pounds per hour of boiler steam combine with the geothermal steam to produce 15.20 gross MW and 12.32 net MW.

\subsubsection{Other Factory Retrofit Options Evaluated} Initially other factory retrofit equipment were evaluated. However, with the evolvement of the proposed system, each was eliminated for various reasons. 
- Brine heat exchangers can be used effectively in many locations within the factory. These demands presently account for a smal1, but significant use of steam. However, with the elimination of brine transmission from the well site, the possibility of brine usage becomes mute.

- Steam can be utilized to heat ambient air, which in turn can be introduced to a rotary drum dryer, producing a drier bagasse. This fuel will burn at a higher combustion temperature with a lower latent heat load, which increases boiler steam generation. The option was rejected because sufficient quantities of bagasse will exist for the thermal load of the factory, and it is more cost effective to admit steam into the turbogenerator to generate additional power. However, the option is a valid proposal if the bagasse moisture is causing poor burning characteristics in the boiler.

- During weekends, when the cane factory is stopped, there is no process steam demand. Compensation for this steam system imbalance can be made through the use of back pressure steam turbines exhausting to the atmosphere. These turbines can drive boiler auxiliaries and condenser water pumps during the weekend periods.

Increasing the turbogenerator condenser capacity to accept more steam during the weekends could also accommodate the steam imbalance. Discussions with General Electric Company, the turbogenerator manufacturer, confirmed that this can be accomplished. More bagasse burning must be shifted to the weekdays to reduce the total steam consumption during weekends. 
With a larger condenser, the reduced steam production on weekends can be absorbed in the condenser at a slightly raised back pressure. This is the option selected for factory retrofit.

- Additional power can be generated by raising the power factor to 0.95 . However, if the unit is to be base loaded at a constant export of approximately $12.3 \mathrm{MW}$, the turbogenerator is already near maximum condenser loading during the weekends. Additional çapacity through power factor correction could only be achieved during production periods, or five of the seven days of any week. It was decided to keep the turbogenerator export at a constant base load.

\subsection{SYSTEM MANNING SCHEDULE}

Table 6-5 lists the number and titles of the specific operating personnel required for the well site facilities and transmission pipeline. Since the operations are part of a larger industrial activity, supervisory functions are assumed to be absorbed in the cane factory overhead.

Support personnel will also be drawn from the larger maintenance pool of the factory. Members of each trade listed need not devote their full time to the repair activities of the geothermal system, but will be assigned tasks as the need arises. It is also likely that the operators will make minor repairs without calling on the maintenance crew. 
TABLE 6-5

MANNING SCHEDULE

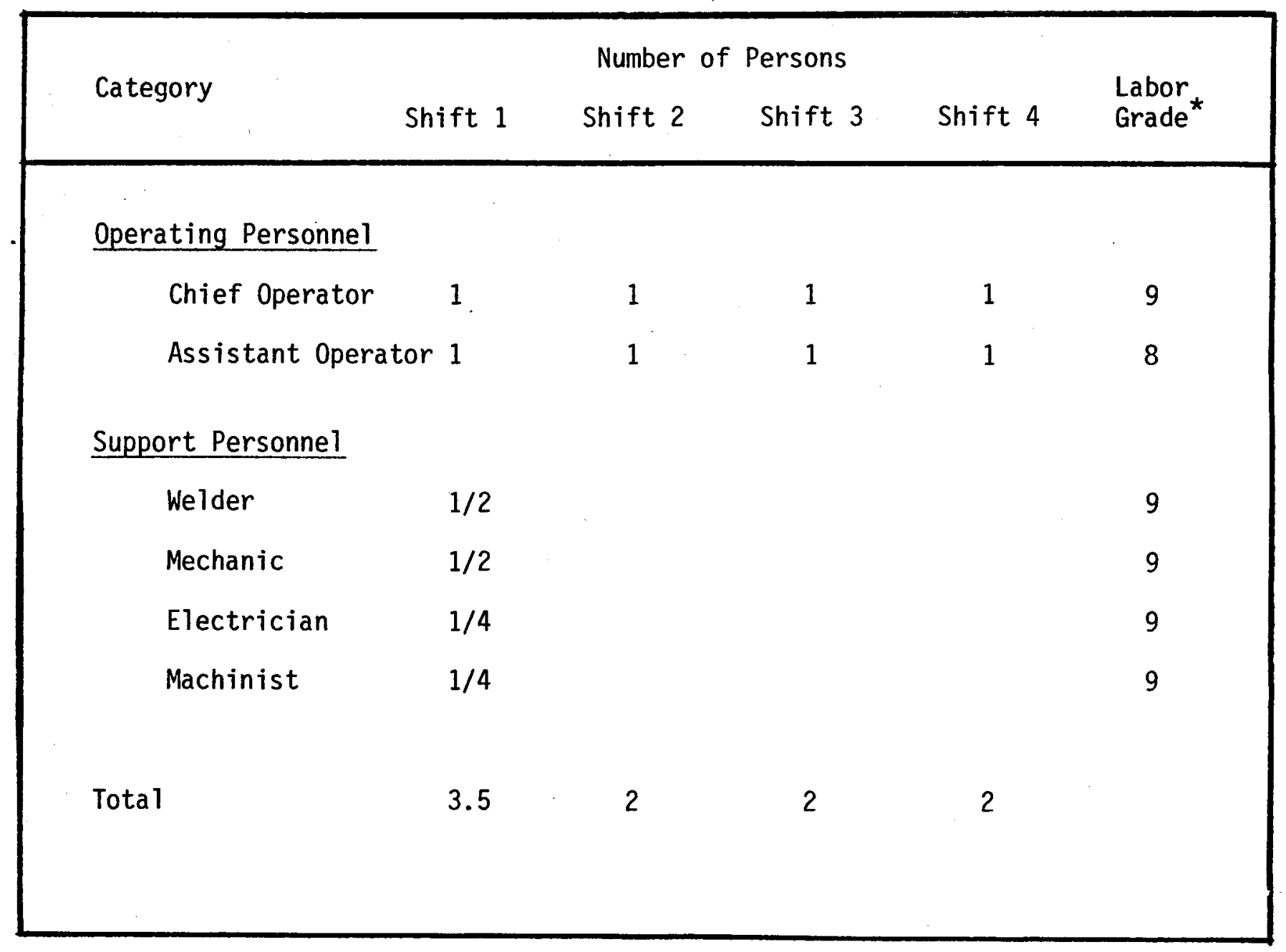

* Standard Hawaiian sugar industry union labor classification on scale of 1 through 11 . 


\section{REFERENCES}

6-1 Humme, J. T., "Engineering and Economic Analysis for the Utilization of Geothermal Fluids in a Cane Sugar Processing Plant, 2nd Quarterly Report," Puna Sugar Company for USDOE, Keaau, Hawaii, October, 1978. 
Section 7

PROJECT SCHEDULE

A planning, design, and construction schedule for this project has been developed for the five year period from 1978 through 1982. The schedule assumes all milestones will impact positively on the project, enabling the succeeding tasks to progress with the minimum of delay. Figure 7-1 graphically relates the preliminary estimate of the time requirements and relationship of tasks. The schedule should be viewed as providing a reasonable assessment, albeit constrictive, of the time train within which the project can be completed. The actual block of time assigned to each component may shift upon further detailed analysis and actual final design.

\subsection{FEASIBILITY STUDY}

The tasks associated with this particular report fulfills the requirement of a preliminary conceptual study for the direct utilization of geothermal resources at Puna Sugar Company. This report outlines the basic information required in further evaluative processes by the Puna Sugar and Amfac staff and management. The project at this point marginally meets the minimum corporate requirements for profitability.

\subsection{CORPORATE FUNCTIONS}

Corporate policy allows that the initial economic analysis be completed on a corporate fund basis. Following this guideline, this report's economic section is predicated on internally financed capital. But in a 
Peasibility Study

Corporate Punctions

evaluatio

Approval to continue Evaluation

Exploration Pernit

Dethiled Wellofte Selection Study

roject Approval

123456789101112123456789101112123456789101112123456789101112123456789101112123

Project ronmental Impact Statement

Mining Lease Megotiations

Pipeline Easement Negotiation:

Power Contract Negotiations

Helleste Functions

Dri111ng Permit

Hell No. 2 Drilling \& Testing

Hell Mo. 3,4,5 Drilling \& Teating

Engineer ing

Materials Procurement

Other Pernits

Plice Preparation

startup and shetedion

Plpeline Funct ions

Eng Ineer ing

Permit:

Materials Procurement

Construct ion

actory Retrofit Punction

Drilling Permit

Water Hell No. 1 \&

Drilling \& Testing

Engineer 1ng

rement

Construction
Constrats

Commencement of Operation

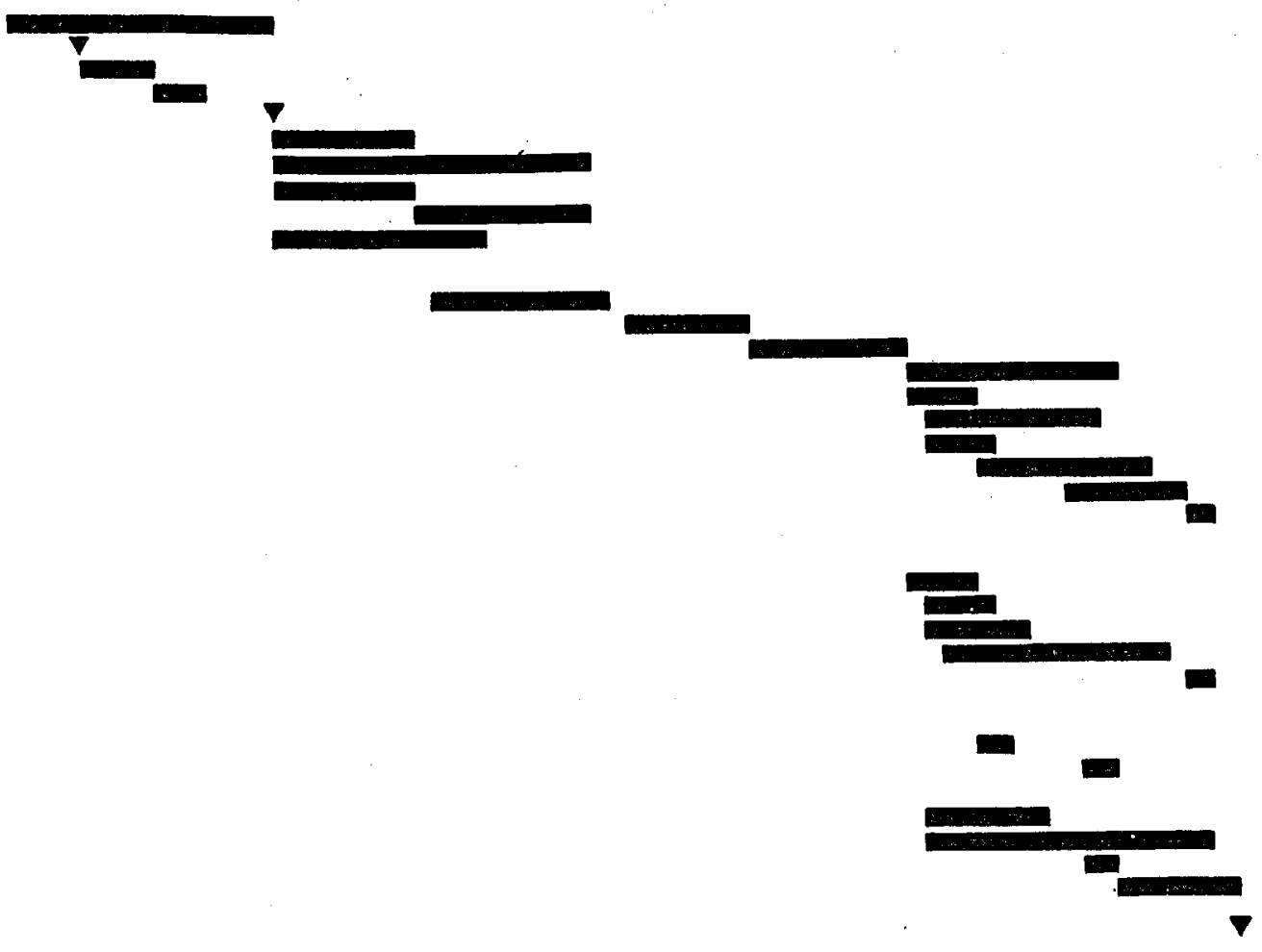

FIGURE 7 - 1

PROJECT SCHEDULE

(1) 
large project of this nature, other financing options are available, most notably the mechanism of the geothermal loan guarantee program. A detailed treatise on such options is beyond the scope of this work, but the options must be evaluated prior to even preliminary project approval commitments.

Although economic considerations are primary, they are but one of several other evaluative criteria which must be handled for project implementation. The question of geothermal ownership rights must be further addressed and resolved.

Other considerations oftentimes are larger questions of corporate investing and operating philosophy. An example is the industry concern of sugar marketability and price. Since the demise of the stabilizing Sugar Act in 1974, the industry has witnessed a volatile product pricing structure that makes commitment of large capital expenditures at times risky.

Notwithstanding these corporate considerations, a detailed site investigation can proceed. With a project approval in concept, an environmental impact statement can be drafted and financing, mining lease, power sales, and pipeline easement negotiations can proceed. This phase of fundamental corporate activity is scheduled to be completed by the end of 1980 .

\subsection{WELLSITE FUNCTIONS}

Progression to wellsite activities basically commits hard dollars to the project. While the preceding evaluative processes often are subjective, the field work is generally bound by prudent engineering and construction standards. Following well drilling permit receipt, the drilling and testing of at least two wells must be completed. Assuming results of 
the well tests are positive, the other three wells can be drilled, engineering completed, materials procured, and construction can proceed. The total process, including permit application, is expected to span a period of 29 months from August, 1980 through December 1982.

\subsection{PIPELINE FUNCTIONS}

The transmission steam line work is scheduled entirely in 1982, with completion in December, 1982. This will allow a one month startup and shakedown period for both the wellsite facilities and the pipeline, prior to the sugar factory production termination at the end of 1981 for the annual repair season. This startup period will not have the benefit of the turbogenerator changes, since the turbogenerator work can only be scheduled during the factory repair period. However, it is not expected to reduce the validity of the pipeline and wellsite startup tests, as the steam can be accommodated at the factory by other means.

\subsection{FACTORY RETROFIT FUNCTIONS}

As with the pipeline work, efforts to retrofit the factory system to accommodate geothermal steam will begin in 1982. Water wells can be drilled in the factory grounds during production. Much of the other prerequisite preparatory work can also proceed during the grinding campaign. Only work involving modifications to the turbogenerator need to wait until the annual repair period in January, 1983. During this period, the turbogenerator condenser must be replaced by a larger unit. The turbine rotor, governor, and extraction valve modifications must also be effected during this time. Startup is expected to be normal, as there will be minimal new untested equipment going on line. 


\subsection{COMMENCEMENT OF OPERATION}

The geothermal wells and pipeline need to be warmed up just prior to the end of the annual factory repair season. The inauguration of commercial geothermal utilization can then commence with the startup of the factory for the production year. That eventful day should be in early February, 1983. 


\section{Section 8}

\section{RISK ASSESSMENT}

Economic endeavors by their nature involve associated risks. Many risks are common to all systems. However, some are peculiar to their respective projects, and it is that group this section addresses. The particular concerns of reliability must be considered in the planning decision of land use and facilities.

\section{1 VOLCANISM AND TECTONIC MOVEMENT}

The entire island has been formed through construction by volcanoes and movements of the earth's crust associated with plate tectonics. Previous work by the U. S. Geological Survey (USGS) has mapped areas of relative risk due to volcanism and tectonics for the island, which is summarized in Figure 8.1. The USGS work has categorized volcanic hazard into two broad groups, direct and indirect hazards. Among the first type are falling rock fragments, lava flows, drifting volcanic gases, and particleand-gas clouds, while indirect hazards are ground movements that include subsidence, surface ruptures, earthquakes, and tsunamis. Each involves risk to humans and facilities although not necessarily simultaneously.

\subsubsection{Direct Hazards}

Falling Rock Fragments. The activity of a particular eruptive episode is a function of several interrelated factors, among which are the amount of magma, the gas quantity and pressure in the magma, and the size, shape and number of eruptive vents. Because of the highly fluid basaltic nature 


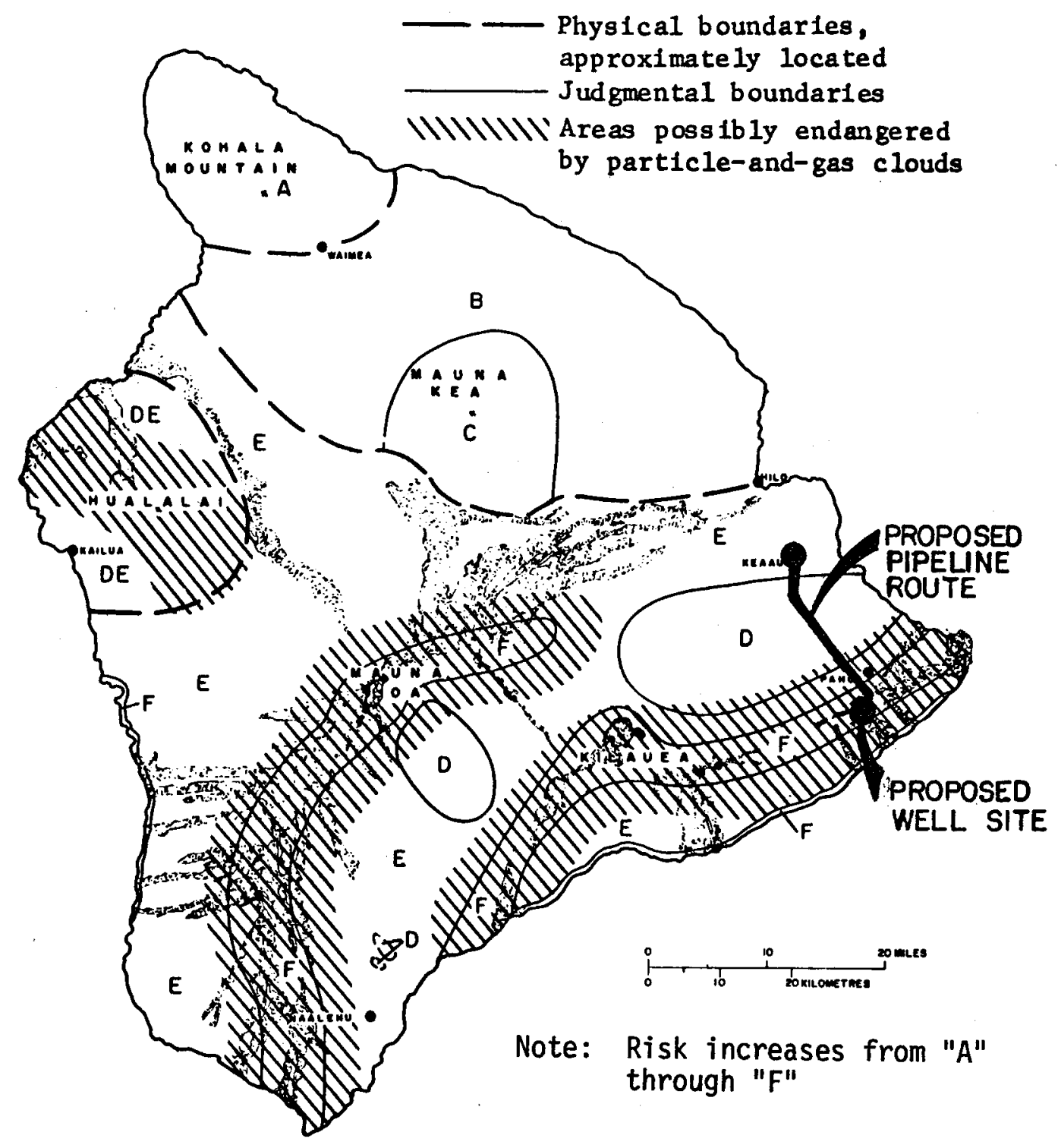

Figure 8-1

Zones of Overall Relative Risk From Volcanic Hazards

From: Mullineaux and Petersen, 1974 
of the magma, magmatic gases are allowed to escape. This attenuates subsurface pressure buildup and results in the relatively quiet eruptive behavior characteristic of historic Hawaiian volcanism. Explosive type activity is rare for Mauna Loa and Kilauea, and usually occurs in the caldera area. There is no known method of preventing or mitigating a volcanic eruption.

Eruptive fountains will eject a gradation of rock sizes into the atmosphere. The larger and denser fragments deposit closer to the vent, while smaller or less dense material are carried further away.

Little danger to humans is likely, since prior notification of imminent volcanic activity will probably be available. Kilauea is one of the most intensely monitored areas in the world, due to its seismic activity. Subsurface movement and surface inflation are measured on a regular basis.

Substantial property damage risk from falling fragments has been judged to exist in the Kilauea caldera and rift zones although even with an explosive vent, fallout is limited to less than one mile. Figure 8-2 indicates the areas of high relative risk to property.

It should be pointed out here that there is a distinction between fallout damage and lava flow inundation. Damage from aerial bombardment is very limited in areal extent, and generally major damage will not occur beyond a quarter mile from the erupting vent. Assuming that a random distribution of eruptive vents will occur throughout the East Rift Zone, an approximate value can be determined for probability of well site fragment fallout damage from a vent within a quarter mile radius of a well site. 


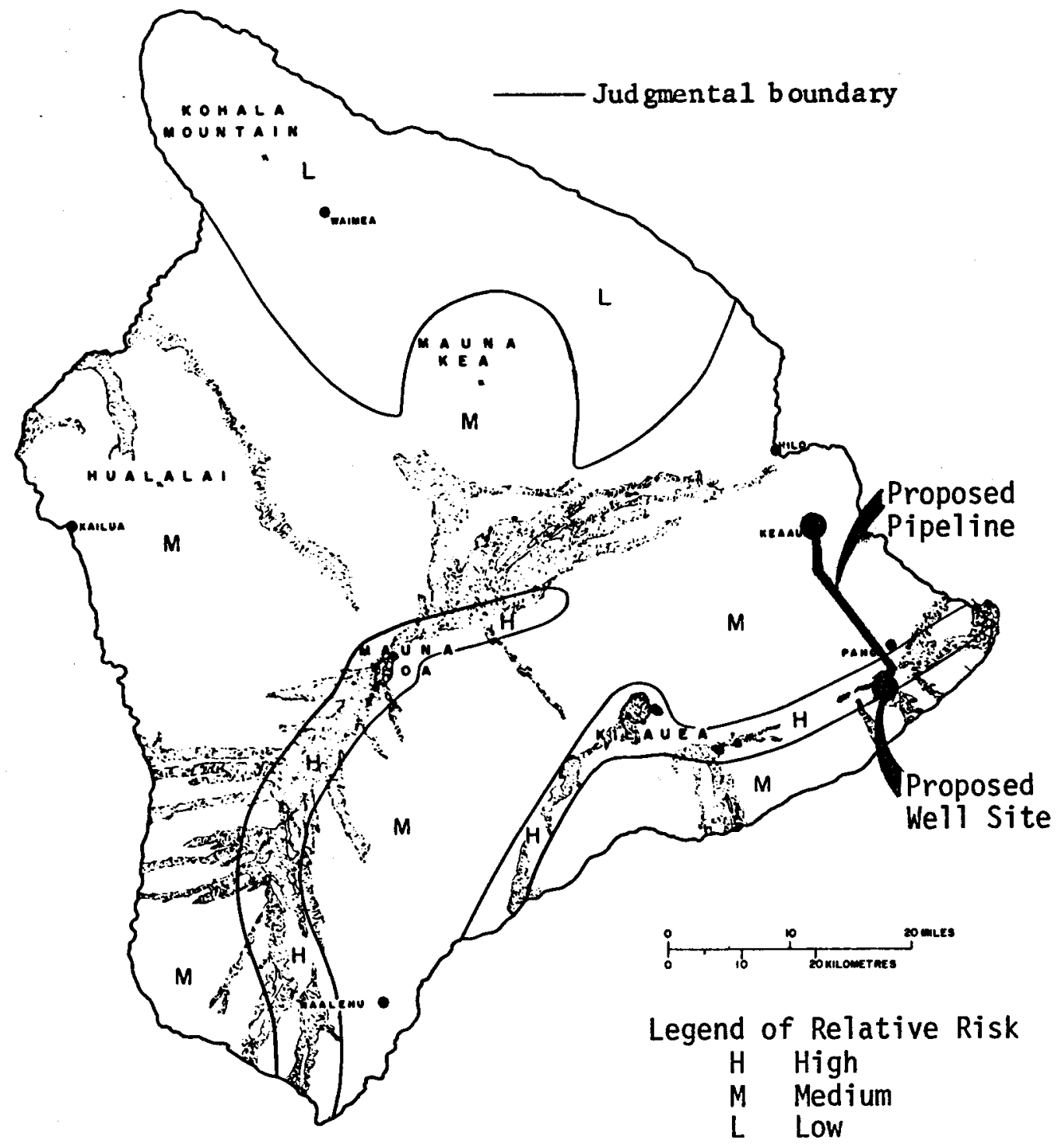

Figure $8-2$

Zones of Relative Risk From Falling Volcanic Fragments From: Mullineaux and Petersen, 1974 
The rift zone area from Heiheiahulu to Cape Kumukahi contains approximately $1.2 \times 10^{9}$ square feet of area in which about 40 eruptive vents have been created since 1750. Figure 8-3 indicates the area evaluated. A well site will be within a quarter mile radius of a vent and be subjected to damage on an average of once every 4900 years from fallout. As a matter of interest the average frequency increases to once in 1200 years for a 0.5 mile radius and once in 300 years for a one mile radius around a wellsite in the East Rift Zone.

Lava Flows. Molten lava from eruptive vents generally assumes an overall lobate shape, with the fingers progressing toward lower elevations. With major volcanic activity concentrated in the caldera and rift zones, the highest zones of risk are in these areas as illustrated in Figure 8-4.

The lavas are classified into two main types, pahoehoe and aa, with gradations in between. Pahoehoe assumes a smooth and glossy surface, with a ropy form. Individual flows are thin and range in thickness from a few inches to as much as eight feet. Aa lava, on the other hand, is extremely rough and clinkery. Individual flows are generally thicker than the pahoehoes, reaching 50 feet at some locations, but averag̀ing much less, perhaps in the order of 5 to 25 feet thick.

Specific paths of the lavas can be unpredictable. While the general direction of flow is downslope, local solidification of the flow may cause directional movement unlike that which would be expected for a pure liquid.

It is not possible to stop a large flow economically. However, even with the unpredictable movement of lava streams, it is possible to divert flows with some high degree of probable success. This is especially true if 


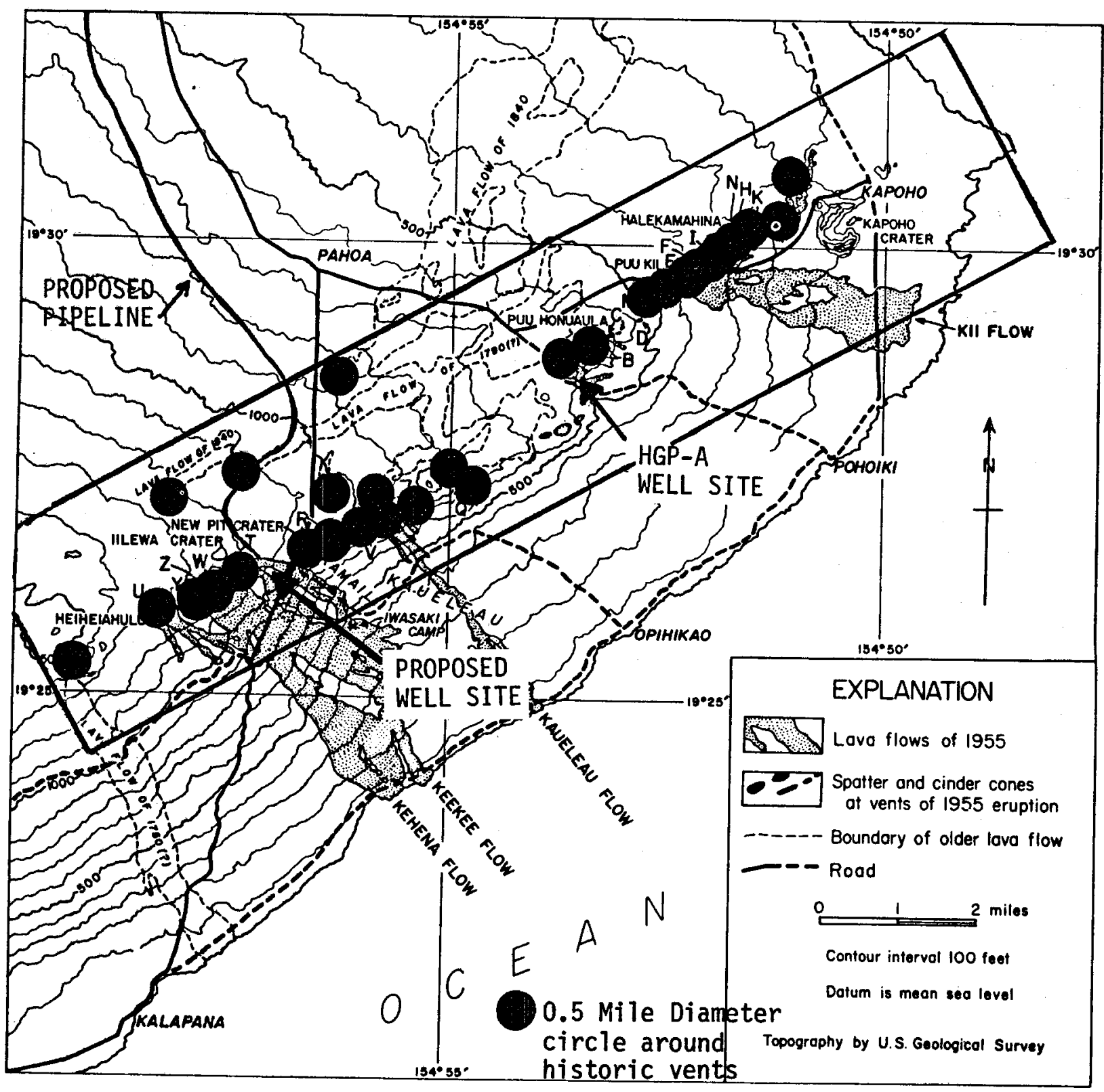

Figure 8-3

Eruptive Vents in the Lower East Rift Zone Adapted from Macdonald and Abbott, Volcanoes in the Sea University of Hawai i Press, p. 86 


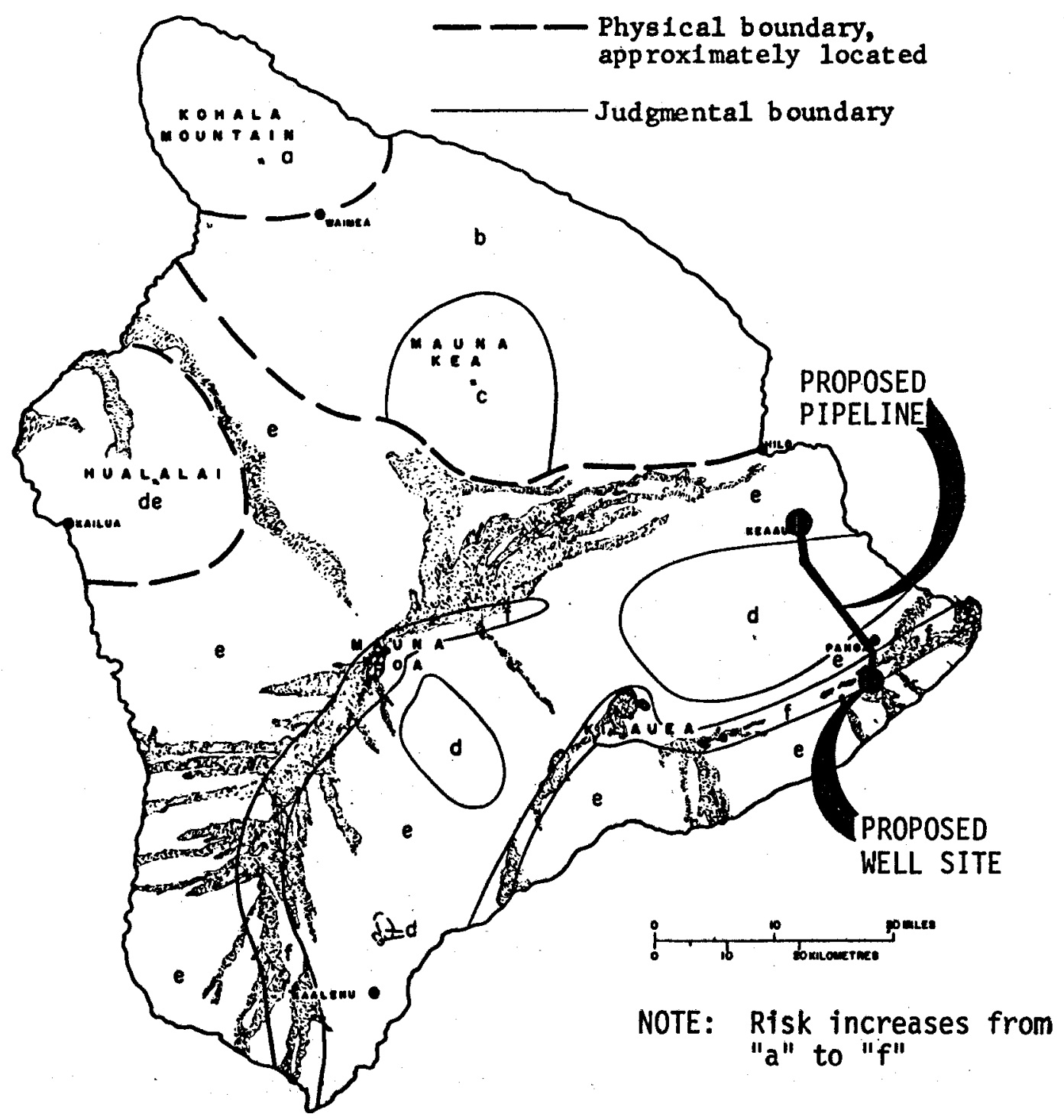

Figure 8-4

Zones of Relative Risk From Lava-flow Burial

From Mullineaux and Petersen, 1974 
only a small parcel of land such as a well site need be protected, with diversion of lava flows probably taking the form of raised sections and dikes. The fact that flowing lava can be diverted was clearly evidenced during the Kilauea eruptions of the early 1970's, when lava was channeled along roadways that had sufficient gradient.

It is one situation to consider diversion around a small parcel, but it is quite another to protect a pipeline crossing a high risk area. It is not economically feasible to protect the pipeline and it must be assumed that portions of the pipeline are expendable.

Beyond the rift zone area, damage probability to any facility diminishes rapidly. It can be noted here that while the Puna Sugar factory at Keaau is located in a Zone $\mathrm{E}$, metropolitan $\mathrm{Hilo}$ is almost entirely within that same zone. There has never been serious consideration given to lava inundation of an economic project in the Hilo-Keaau area, a reflection of confidence given by investors to the volcanic stability of the area.

Drifting Volcanic Gases. Magmatic gases that are liberated during eruptions are a major source of concern to human welfare but are not expected to affect equipment to any substantial degree. The relative zones of risk are identical to that of falling fragments shown in Figure 8-2.

Much of the gases consist of water vapor, carbon dioxide, and sulfur compounds. Other constituents appear in minor amounts and include chlorine and fluorine. Of particular concern to any facility is the sulfur compounds which, upon oxidation, reduce to sulfur trioxide.

Contact with airborne moisture then produces a corrosive sulfuric acid 
mixture. Particular attention must be made to insure that sensitive equipment at the well site will be protected in a controlled atmosphere. A satisfactory solution can be a pressurized control room with treated air intakes.

Particle-and-Gas Clouds. During highly explosive eruptions, rock fragments and gases can eject and spread out very rapidly under the influence of gravity. Temperatures in these clouds attain several hundred degrees and are extremely dangerous to human habitation. The area of highest risk is delineated by the hatched section of Figure 8-1 which defines an area extending four miles outside of the caldera and rift zones.

Only one episode of a particle-gas eruption has occurred during historic times, and therefore any prediction of an occurrence would be extremely speculative. However, it can be said that the probability of a particle gas cloud forming is very small, and is even less likely to occur in the rift zones.

\subsubsection{Indirect Hazards}

Subsidence. Subsidence is manifested in nature by the settling of the entire island, by vertical movement, by slumping of large coastal sections of the island, and by small scale collapse of lava tubes. In addition, developed geothermal areas are prone to vertical movement accompanying withdrawal of subsurface hydrothermal fluids.

Areas that exhibit relatively high subsidence risk due to natural causes are shown in Figure 8-5. Generally, natural subsidence is a gradual process and large sudden movements occur infrequently. Risk will be greatest for long pipelines traversing a high risk area. The impact will be less with 


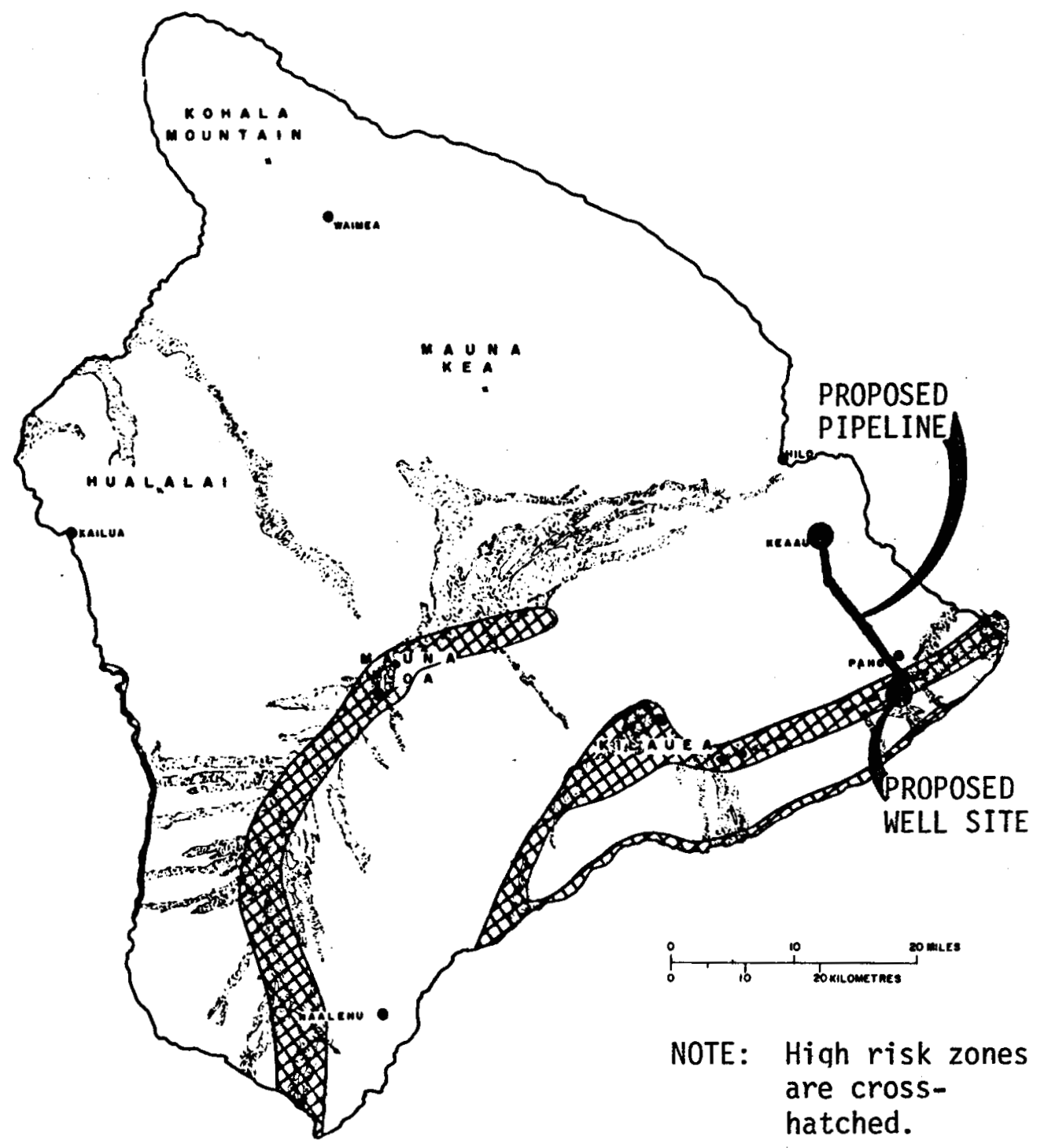

Figure 8-5

Zones Subject to High Risk From Subsidence

From: Mullineaux and Petersen, 1974 
large land movements and catastrophic during sharp vertical movements in a confined area. While pipelines are designed for some flexibility, ground movements might be great enough to exceed the bending capacity of the pipeline.

Surface Ruptures. Ruptures on the surface occur when there is relative movement of rock masses in directions away, transverse, or vertical to each other. These movements seldom endanger lives although pipelines can be highly susceptible to damage if the rupture is great enough. The area of highest risk again is in the caldera and rift zone as shown in Figure 8-6. Large ruptures are relatively rare, but several hundred smaller cracks have been noted during historic times.

Earthquakes. Of al1 the geophysical phenomena the frequency of seismic occurrences is probably greatest. Earthquakes occur many times during the day and in some instances several thousand have been recorded during a 24 hour period. Most are of little consequence but occasionally, earthquakes of sufficent strength will cause some damage. Two recent earthquakes that did cause damage registered approximately 7.2 on the open ended Richter scale. The first was in 1973 off the shore of Honomu, 12 miles north of Hilo and the other (1975) at Halape, also along the shoreline, south of Kilauea. While damage was reported to some homes on the island, industrial type facilities were not damaged. Interestingly enough, the HGP-A well drilling at the time of the Halape earthquake was nearly complete, but no damage was inflicted on the bore. The severest known Hawaiian earthquake occurred in 1868 in Kau with an estimated modified Mercalli scale intensity of 10 or more in the epicentral area. Considerable damage resulted and major land movement occurred. 


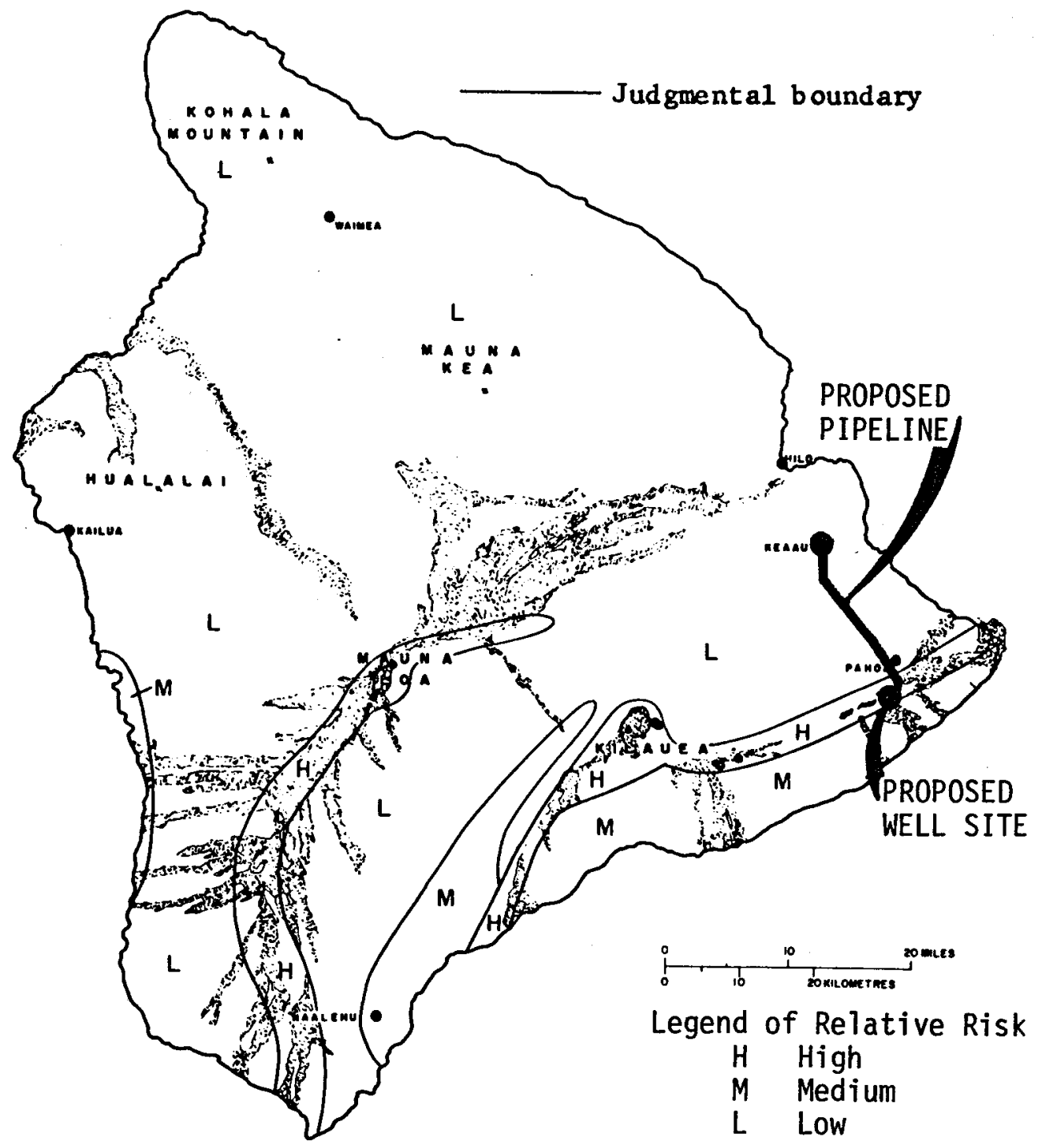

Figure 8-6

General Areas of Risk From Surface Ruptures

From: Mullineaux and Petersen, 1974 
The risk of moderately strong earthquakes is perhaps greatest in the rift zones, but many have been reported throughout the island mass. Hence earthquake occurrences should be regarded as highly probable in any section of the island. For structural design purposes, the entire island is placed with the seismic zone 3 classification to reflect the real possibilities of earthquake activity.

Tsunamis. Ocean waves generated by abrupt movement of rock masses under water or by submarine volcanism, travel at great speeds in the open ocean. While they are hardly noticeable in the open seas, the waves slow down when approaching land, and become very massive. Tsunamis with waves as high as 60 feet have been reported in the islands. For this project however, tsunamis cannot be regarded as a valid risk since the project location will be removed from any tsunami inundation area.

\subsection{VANDALISM}

Exposure and accessibility are invitations to vandalism. In this particular project, the well site and factory areas will be secure, as both will be manned at all times. However the unattended pipeline cannot be economically protected against damage by vandalism. Use of the service roads can be restricted but access to the area, near the pipeline corridor should and will remain accessible. Much of the pipeline corridor passes through remote areas where accessibility may lead to vandalism.

Geothermal development in Hawaij is presently a highly charged emotional issue which may be symptomatic of vandalistic problems. It is hoped that prior to implementation of this project, a more moderate perspective towards geothermal development will have been arlopted. 


\section{3 WELL BLOWOUT}

An operating hazard during drilling and production of the geothermal wells is that of blowout. Blowouts are uncontrolled releases of geothermal fluids through or near the wellhead, and several have occurred elsewhere in the past.

While blowouts are spectacular, they are far less serious than they appear, primarily because the fluids are not flammable and can be eventually brought under control. The California Division of $0 i l$ and Gas has distinguished five types of blowouts, after a comprehensive study of the hazard. It was determined that all five types of blowout can be prevented with a cautious attitude and adherence to prudent design and operating procedures.

\subsection{RESOURCE SUPPLY RELIABILITY}

Sales of firm base load power to the utility must be predicated on a reliable source of power. Fortunately, the sugar factory can supply steam to the turbogenerator in the unlikely situation where catastrophic events make geothermal steam unavailable. The existing bagasse and fuel oil fired boiler has sufficient rated capacity to supply process steam and the demands of the turbogenerator. In fact, the factory has operated under this regime in the past, where export load to HELCO was approximately 12 MW.

The conversion to boiler supplied steam can be accomplished within seconds as the boiler is on line at all times, firing bagasse. To supply any additional steam demand only requires lighting off the four boiler fuel oil burners, which can be done remotely by the boiler operator. 


\section{REFERENCES}

8-1 Mullineaux, Donal R., and Petersen, Donald W., Volcanic Hazards on the Island of Hawaii, Open file report 74-239, USGS, 1974.

8-2 Stephen-Hassard, Q. Dick, et al., The Feasibility and Potential Impact of Manganese Nodule Processing in Hawaij, Dept. of Planning and Economic Development, State of Hawaii, Honolulu, February 1978.

8-3 Anderson, David N., "Environmental Regulations," from Proceedings, Geothermal Seminar, Department of Research and Development, County of Hawai i, Hilo, Hawai i, October 18-19, 1977.

8-4 Kamins, Robert M., Revised Environmental Impact Statement for the HGP Research Station Utilizing the HGP-A Well at Puna, Island of Hawaij, Department of Planning and Economic Development, State of Hawaii, Honolulu, Hawai i, March, 1978. 
Section 9

ECONOMIC ANALYSIS

The design concept for geothermal utilization at the Puna Sugar factory is for direct substitution into the process steam stream plus injection into a turbogenerator to produce additional electric power sales. The effect on increasing the power sales schedule, savings in fuel oil consumption, and sales of geothermal byproducts offset the geothermal development and operating costs. This section determines the economic profitability and public benefits that accrue from that concept. Additionally; it addresses the alternative financing methods that might be available to the project.

\subsection{ECONOMICS OF THE PROPOSED SYSTEM}

Although Puna Sugar is an independent operating profit center, normal capital funding allocations are from Amfac's internal corporate funds. Disbursements of corporate funds are evaluated by Amfac according to project profitability and overall corporate operating and philosophical objectives. However, to reduce confusion, references to the economic system in this section will be of Puna Sugar rather than Amfac, with the relationship left implicit.

Normal economic procedural practice at Puna Sugar determines initial project feasibility on an internal corporate fund basis, using the discounted cash flow method. In this work, $12 \%$ discount factors are applied 
to both the cash flow and cash requirements to determine net present value (NPV). A project is classified as profitable if the NPV of cash flow exceeds the NPV of the cash requirements.

In addition, a computer aided process can determine a definitive returnon-investment (ROI). Here, an iterative process is employed to vary the cash flow discount factor that equates the NPV of cash flow and cash requirements. In the following subsections, a discussion of the data to develop the cash flow and cash requirements models is presented. The results of that determination produces a $15.1 \%$ project return-on-investment after taxes, marginally meeting Puna Sugar's profitability criteria. Figure 9-1 illustrates the financial flow model that was used in the economic evaluation of this project.

\subsubsection{Project and Equipment Life}

The duration of the project life has a visible effect on ROI, and with large capital expenditures, due care must be afforded in the selection of the evaluative period. This is particularly true if the capital investment is concentrated within the early years of the project, as is the case in this study. As an example, the effect of a change in life from 10 to 20 years for this project increases the ROI by 4.2 percentage units.

Discussions were held among project members and a 20 year life from 1983 through 2002 was established for the system. This reflects a consensus judgment in part based on the reliable life of the hardware. It is also in line with the project life utilized in the planning, development, and operation of the existing Puna Sugar steam and power generating facility. 


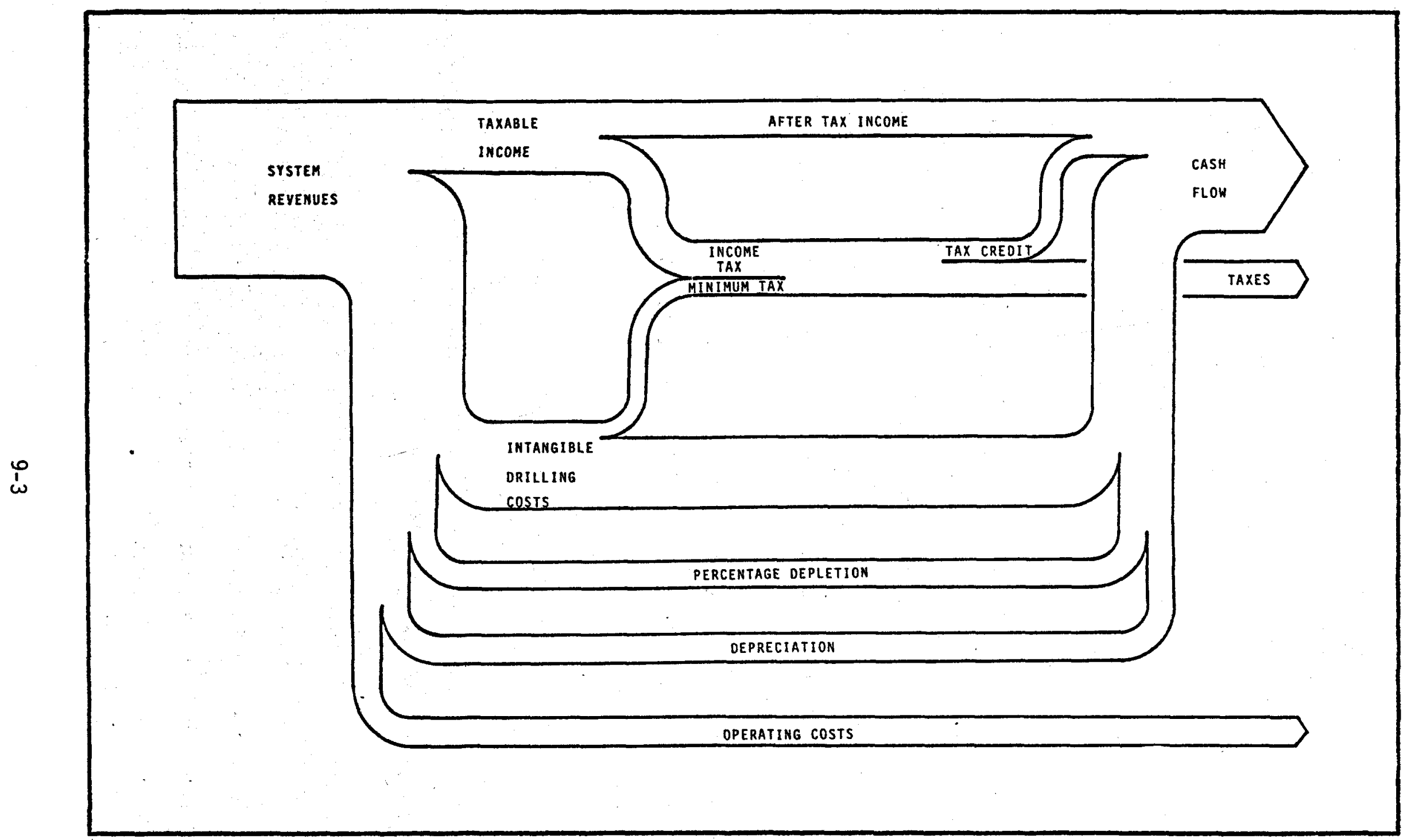

Figure 9-1

Project Financial Flow Model 


\subsubsection{Cost Escalation}

A11 project costs and revenues are developed in terms of 1978 dollars. Escalation factors are determined for several categories of system costs and revenues. These escalation factors, ranging from $7 \%$ to $8 \%$ annually, are applied to the 1978 values, resulting in a determination of future values in terms of 1978 dollars.

\subsubsection{System Cash Requirements}

After the synthesis of the proposed system, estimates were prepared in order to determine cash outlay requirements during the construction phases of the project. The construction phase of the proposed project is scheduled to span two years. In 1981, two wells are to be drilled and tested. If successful, the remaining wells, wellsite work, transmission pipeline work, and factory retrofit work are scheduled to be completed by the end of 1982 . The tota1 system cash requirements will be $\$ 1,494,000$ in 1981 and $\$ 27,022,000$ in 1982 as shown in Table 9-1. In terms of 1978 dollars, $\$ 21,048,000$ are required for the project.

Wellsite Cash Requirements. Wellsite cash requirements are the sum of two categories of costs, capitalized costs and intangible drilling costs (IDCs). Under the Energy Tax Act of 1978, the owner is given the option to capitalize or expense IDCs.

Trial computations were made to determine ROI sensitivity to various percentages of well cost capitalization. Table 9-2 shows that the ROI for the proposed project is highest when IDCs are expensed to the maximum extent permissible by law. Although expenses vary from we11 to we11, about $50 \%$ of the cost of a well typically qualifies as IDCs. That value has been used for calculations in this study. Wellsite cash requirements are 
TABLE 9-1

PROJECT CASH REQUIREMENT S'UMMARY

\begin{tabular}{|clc|}
\hline YEAR & \multicolumn{1}{c|}{ ITEM } & $\begin{array}{c}\text { CASH REQUIREMENTS } \\
\text { (DOLLARS) }\end{array}$ \\
\hline 1981 & Wel1 Site & $\frac{1,494,000}{1,494,000}$ \\
1981 & Total Cash Requirement & $7,969,000$ \\
1982 & Wel1 Site & $17,728,000$ \\
1982 & Resource Transmission & $1,325,000$ \\
1982 & Factory Retrofit & $27,022,000$ \\
1982 & Total Cash Requirement & \\
\hline
\end{tabular}


TABLE 9-2

EFFECT OF WELL COST CAPITALIZATION ON ROI

\begin{tabular}{|ccc|}
\hline $\begin{array}{c}\text { CAPITALIZED } \\
\text { PERCENTAGE } \\
(\%)\end{array}$ & $\begin{array}{c}\text { EXPENSED (IDC) } \\
\text { PERCENTAGE } \\
(\%)\end{array}$ & $\begin{array}{c}\text { ROI } \\
(\%)\end{array}$ \\
\hline 0 & 100 & 15.35 \\
25 & 75 & 15.21 \\
50 & 50 & 15.06 \\
75 & 25 & 14.92 \\
100 & 0 & 14.78 \\
\hline
\end{tabular}


$\$ 1,494,000$ for 1981 and $\$ 7,969,000$ for 1982 as shown in Table 9-3.

Transmission Pipeline Cash Requirements. Upon completion and successful testing of the first two wells, design and construction of the transmission pipeline is to be initiated, with completion due in 1982. Table 9-4 is the breakdown of costs for the pipeline, which shows that the total cash requirements for the pipeline will be $\$ 17,728,000$ in 1982 .

Factory Retrofit Cash Requirements. Design of the factory retrofit work is to commence following completion and proving of the first wells in 1981 . Completion of this work is scheduled in 1982. A breakdown of factory retrofit costs is illustrated in Table 9-5. Total cash requirements in 1982 for the factory retrofit portion of the project is $\$ 1,325,000$.

\subsubsection{System Revenues}

All revenues anticipated from the implementation of the project are developed based on projections from 1978 costs of electric power, $\mathrm{SO}_{2}$, fuel oil and capacity charges. The revenues that would be obtained under baseline operating conditions are deducted from the sum of all other revenues to obtain gross revenues attributable to implementation of the project. Table 9-6 shows the anticipated revenues during the 1 ife of the project. The first year revenue is $\$ 3,838,000$ and increases annually due to inflationary trends.

Power Sales. Section 6 shows that by implementing the proposed system, $12,320 \mathrm{~kW}$ of electricity can be exported on a continuous basis during the 48 week power plant operating season. This is equivalent to an annual export of $99,348,500 \mathrm{kWh}$. With the anticipation that the 1978 electric power demand rate of 24.36 mills per kWh will increase at $8 \%$ per year, power sales revenue for the first year (1983) will be $\$ 3,566,000$. 
TABLE 9-3

WELL SITE CASH REQUIREMENTS

\begin{tabular}{|c|c|c|c|c|}
\hline YEAR & ITEM & $\begin{array}{c}\text { CASH } \\
\text { REQUIREMENTS } \\
\text { (DOLLARS) }\end{array}$ & $\begin{array}{c}\text { IDC } \\
\text { (DOLLARS) }\end{array}$ & $\begin{array}{c}\text { NON-DEPRECIABLE } \\
\text { FRACTION } \\
\text { (DOLLARS) }\end{array}$ \\
\hline $\begin{array}{l}1978 \\
1978 \\
1978 \\
\\
1978 \\
1978 \\
1978\end{array}$ & $\begin{array}{l}\text { Project Evaluation } \\
\text { Work } \\
\text { Site Preparation } \\
\text { Water Storage } \\
\text { Two-Phase Flow } \\
\quad \text { Separator } \\
\text { Silencer } \\
\text { Production Well } \\
\text { Subtotal }\end{array}$ & $\begin{array}{r}5,000 \\
39,122 \\
\\
61,980 \\
30,000 \\
1,000,000 \\
1,186,102\end{array}$ & $\frac{500,000}{500,000}$ & $\frac{500,000}{500,000}$ \\
\hline 1981 & $\begin{array}{l}\text { Total Escalalated } \\
\text { Cost ( } 8 \% \text { per yr) }\end{array}$ & $1,494,147$ & 629,856 & 629,856 \\
\hline $\begin{array}{l}1978 \\
1978 \\
1978 \\
1978 \\
1978 \\
1978 \\
1978 \\
1978 \\
1978 \\
1978\end{array}$ & $\begin{array}{l}\text { Site Preparation } \\
\text { Water Development } \\
\text { Fire Protection System } \\
\text { Cooling Water System } \\
\text { Buildings } \\
\text { Electrical Services } \\
\text { Productions Wells } \\
\text { Injection Well } \\
\text { Geothermal Evaporators } \\
\mathrm{H}_{2} \mathrm{~S} \text { Conversion Equipment }\end{array}$ & $\begin{array}{r}281,661 \\
110,953 \\
20,107 \\
41,580 \\
40,000 \\
102,721 \\
3,000,000 \\
1,000,000 \\
672,469 \\
587,805 \\
\end{array}$ & $\begin{array}{r}1,500,000 \\
500,000\end{array}$ & $\begin{array}{r}1,500,000 \\
500,000\end{array}$ \\
\hline 1978 & Subtotal & $5,857,296$ & $2,000,000$ & $2,000,000$ \\
\hline 1982 & $\begin{array}{l}\text { Total Escalated } \\
\text { Cost ( } 8 \% \text { per yr) }\end{array}$ & $7,968,787$ & $2,720,928$ & $2,720,928$ \\
\hline
\end{tabular}


TABLE 9-4

TRANSMISSION PIPELINE CASH REQUIREMENTS

\begin{tabular}{|clr|}
\hline YEAR & \multicolumn{1}{c|}{ ITEM } & $\begin{array}{c}\text { CASH } \\
\text { REQUIREMENTS } \\
\text { (DOLLARS) }\end{array}$ \\
\hline 1978 & Pipeline & $4,881,000$ \\
1978 & Thermal Insulation & $4,117,400$ \\
1978 & Concrete Trenches & $3,640,500$ \\
1978 & Underpasses & 49,300 \\
1978 & Service Roads & 342,500 \\
1978 & Subtotal & $13,030,700$ \\
1982 & Total Escalated & $17,728,100$ \\
& Cost (8\% per $y r)$ & \\
\hline
\end{tabular}


TABLE 9-5

FACTORY RETROFIT CASH REQUIREMENTS

\begin{tabular}{|clc|}
\hline YEAR & \multicolumn{1}{|c|}{ ITEM } & $\begin{array}{c}\text { CASH REQUIREMENTS } \\
\text { (DOLLARS) }\end{array}$ \\
\hline 1978 & $\begin{array}{l}\text { Turbogenerator } \\
\text { Modifications }\end{array}$ & 598,500 \\
1978 & Water Wel1s & 297,100 \\
1978 & Electrical Services & 116,600 \\
1978 & Subtotal & 974,200 \\
1982 & Total Escalated & $1,325,400$ \\
& Cost (8\% per yr) & \\
\hline
\end{tabular}


The power sales revenues throughout the life of the project are shown in Table 9-6.

$\mathrm{SO}_{2}$ Revenues. Section 6 details that 887 tons of $\mathrm{SO}_{2}$ will be recovered at the wellsite annually. At a 1978 market price of $\$ 200$ per ton, the first year revenues from the sale of $\mathrm{SO}_{2}$ in 1983 will be $\$ 261,000$ when escalated at the rate of $8 \%$ per year. The $\mathrm{SO}_{2}$ revenues for 1983 through 2002 are listed in Table 9-6. These figures were determined using an $8 \%$ inflation rate.

Deduction of Baseline Power Sales Revenues. To determine the portion of total power sales that is attributable to the proposed project, the predicted power sales revenue that would be generated under baseline conditions must be subtracted. Under baseline conditions, Puna Sugar Company is required to generate $38,000,000 \mathrm{kWh}$ annually for sale to HELCO. In 1978, the power sales rate was 24.36 mills per $k W h$. At an $8 \%$ annual rate of increase, the baseline power sales will be worth $\$ 1,360,700$ in 1983. An annual increase of $8 \%$ is utilized to escalate baseline power sales revenues throughout the project. The annual amounts are listed in Table 9-6.

Fuel 0il Cost Savings. For baseline conditions, 57,500 barrels of fuel oil are needed annually to fulfill power sales quotas. By implementing the proposed project, fuel oil requirements will be decreased to 3,600 barrels per year. In 1978, the cost of a barrel of fuel oil delivered to Puna Sugar Company was $\$ 12.88$. Using an escalation rate of $8 \%$ between 1978 and 1983, the first year fuel oil savings in 1983 will be $\$ 1,001,000$. Table 9-6 tabulates the annual fuel savings with an $8 \%$ escalation rate beyond 1983. 
TABLE 9-6

ANTICIPATED REVENUES (\$×1000)

\begin{tabular}{|c|c|c|c|c|c|c|}
\hline $\begin{array}{l}\text { ITEM } \\
8 \text { RATE OF } \\
\text { INCREASE } \\
\text { YEAR }\end{array}$ & $\begin{array}{r}1 \\
8.00\end{array}$ & $\begin{array}{r}2 \\
8.00\end{array}$ & $\begin{array}{r}3 \\
8.00\end{array}$ & $\begin{array}{r}4 \\
8.00\end{array}$ & $\begin{array}{r}5 \\
0.00\end{array}$ & $\begin{array}{l}\text { TOTAL } \\
\text { REVENUES }\end{array}$ \\
\hline $\begin{array}{l}1981 \\
1982 \\
1983 \\
1984 \\
1985 \\
1986 \\
1987 \\
1988 \\
1989 \\
1990 \\
1991 \\
1992 \\
1993 \\
1994 \\
1995 \\
1996 \\
1997 \\
1998 \\
1999 \\
2000 \\
2001 \\
2002\end{array}$ & $\begin{array}{r}0.000 \\
0.000 \\
260.659 \\
281.511 \\
304.031 \\
328.353 \\
354.621 \\
382.990 \\
413.629 \\
446.719 \\
482.456 \\
521.052 \\
562.736 \\
607.754 \\
656.374 \\
708.883 \\
765.593 \\
826.840 \\
892.987 \\
964.425 \\
1041.570 \\
1124.890\end{array}$ & $\begin{array}{r}0.000 \\
0.000 \\
3556.330 \\
3840.830 \\
4148.090 \\
4479.930 \\
4838.320 \\
5225.380 \\
5643.410 \\
6094.880 \\
6582.470 \\
7109.060 \\
7677.780 \\
8292.000 \\
8955.360 \\
9671.780 \\
10445.500 \\
11281.100 \\
12183.500 \\
13158.100 \\
14210.700 \\
15347.500\end{array}$ & $\begin{array}{r}0.000 \\
0.000 \\
-1320.620 \\
-1426.260 \\
-1540.360 \\
-1663.580 \\
-1796.650 \\
-1940.390 \\
-2095.620 \\
-2263.260 \\
-2444.320 \\
-2639.860 \\
-2851.040 \\
-3079.120 \\
-3325.440 \\
-3591.470 \\
-3878.780 \\
-4189.080 \\
-4524.200 \\
-4886.130 \\
-5277.020 \\
-5699.180\end{array}$ & $\begin{array}{r}0.000 \\
0.000 \\
1000.670 \\
1080.720 \\
1167.170 \\
1260.540 \\
1361.380 \\
1470.290 \\
1587.910 \\
1714.940 \\
1852.130 \\
2000.300 \\
2160.320 \\
2333.140 \\
2519.790 \\
2721.370 \\
2939.070 \\
3174.190 \\
3428.120 \\
3702.360 \\
3998.540 \\
4318.420\end{array}$ & $\begin{array}{r}0.000 \\
0.000 \\
340.646 \\
340.646 \\
340.546 \\
340.546 \\
340.546 \\
340.546 \\
340.546 \\
340.546 \\
48.136 \\
48.136 \\
48.136 \\
48.136 \\
48.136 \\
48.136 \\
48.136 \\
48.136 \\
48.136 \\
48.136 \\
48.136 \\
48.136\end{array}$ & $\begin{array}{r}0.000 \\
0.000 \\
3837.670 \\
4117.440 \\
4419.570 \\
4745.880 \\
5098.300 \\
5478.910 \\
5889.960 \\
6333.910 \\
6520.860 \\
7038.680 \\
7597.920 \\
8201.900 \\
8854.210 \\
9558.630 \\
10319.300 \\
11141.100 \\
12028.400 \\
12986.800 \\
14021.800 \\
15139.600\end{array}$ \\
\hline
\end{tabular}

Legend

$\begin{array}{cl}\text { Item } & \\ 1 & \mathrm{SO}_{2} \text { Sales } \\ 2 & \text { Power Sales } \\ 3 & \text { Baseline Power Sales } \\ 4 & \text { Fuel Oil Savings } \\ 5 & \text { Net Capacity Charge }\end{array}$


Net Capacity Charge. The net capacity charge is the combination of total capacity charge less the baseline capacity charge and the transformer charge. These charges are defined as follows:

- The capacity charge is a fee paid by HELCO to Puna Sugar. It is a $\$ / \mathrm{kW}$ multiplier applied to the maximum $\mathrm{kW}$ exported by Puna Sugar, the maximum $\mathrm{kW}$ export rate being negotiated as a part of the dispatch schedule at the start of each year. Contract renegotiation will be necessary prior to the project startup in 1983. By renegotiation, the study anticipates that Puna Sugar can obtain a capacity charge multiplier of $\$ 39.63$ per $\mathrm{kW}$, or $\$ 488,300$ per year beginning in 1983 .

- The baseline capacity charge is the current capacity charge rate being received by Puna Sugar. This charge is fixed by the current contract and expires at the end of 1990. The baseline capacity charge is $\$ 18.50$ per $\mathrm{kW}$ or $\$ 111,000$ per year through 1990. At that time, the baseline capacity charge would be renegotiated to obtain a predicted $\$ 440,200$ per year at $\$ 73.36$ per $\mathrm{kW}$.

- The transformer charge is the fee paid to HELCO by Puna Sugar to amortize the transformer and substation facilities required to connect Puna Sugar's power plant into the HELCO system. The transformer charge is fixed at $\$ 36,500$ annualiy through 1990 . Thereafter, the substation is considered to be fully amortized and no further transformer charges will be incurred.

Table 9-7 indicates how the net capacity charges will be determined for the duration of the project. The net capacity charge is also listed in Table 9-6. 
TABLE 9-7

CAPACITY CHARGE REVENUES

\begin{tabular}{|c|c|c|c|c|}
\hline YEAR & $\begin{array}{l}\text { PROJECT } \\
\text { CAPACITY } \\
\text { CHARGE } \\
\text { (DOLLARS) }\end{array}$ & $\begin{array}{l}\text { BASE LINE } \\
\text { CAPACITY } \\
\text { CHARGE } \\
\text { (DOLLARS) }\end{array}$ & $\begin{array}{l}\text { TRANSFORMER } \\
\text { CHARGE } \\
\text { (DOLLARS) }\end{array}$ & $\begin{array}{c}\text { NET PROJECT } \\
\text { CAPACITY CHARGE } \\
\text { (DOLLARS) }\end{array}$ \\
\hline 1983 & 488,300 & 111,000 & 36,500 & 340,800 \\
\hline 1984 & i" & " & " & " \\
\hline 1985 & $"$ & " & 1 & " \\
\hline 1986 & $"$ & $"$ & $"$ & $"$ \\
\hline 1987 & $"$ & $"$ & $"$ & $"$ \\
\hline 1988 & $"$ & $"$ & $"$ & $"$ \\
\hline 1989 & 11 & $"$ & $"$ & $"$ \\
\hline 1990 & $"$ & " & $"$ & " \\
\hline 1991 & $"$ & 440,200 & 0 & 48,100 \\
\hline 1992 & $"$ & 11 & $"$ & " \\
\hline 1993 & $"$ & $"$ & $"$ & $"$ \\
\hline 1994 & $"$ & $"$ & $"$ & $"$ \\
\hline 1995 & $"$ & $"$ & $"$ & $"$ \\
\hline 1996 & $"$ & $"$ & $"$ & $"$ \\
\hline 1997 & $"$ & $"$ & $"$ & $"$ \\
\hline 1998 & $"$ & $"$ & $"$ & $"$ \\
\hline 1999 & $"$ & $"$ & $" 1$ & $"$ \\
\hline 2000 & $"$ & $"$ & $"$ & $"$ \\
\hline 2001 & " & " & $"$ & " \\
\hline 2002 & 488,300 & 440,200 & 0 & 48,100 \\
\hline
\end{tabular}




\subsubsection{System Operating Costs}

After formulation of the proposed system, estimates of staffing requirements, operating and maintenance costs, utilities, easement lease costs, insurance and royalties were made. Table 9-8 indicates the annual system operating costs from 1983 through 2002. The total operating costs for 1983 will be $\$ 519,000$. Staffing costs are included within 0 \& $M$ costs for each segment of the proposed project and are not listed separately.

Operating and Maintenance Costs. Table 9-9 indicates that the components of $0 \& M$ costs in 1983 are $\$ 390,000$. These costs are expected to increase at an annual rate of $7 \%$ as shown in Table 9-8.

Utilities. Diesel fuel oil costs for the well site diesel electric generator have been considered distinct from the $0 \& M$ costs. In addition, the costs of purchased electrical power to pump water to the well site and the potable water itself have been included in the utility classification. Table 9-9 indicates that 1983 costs for diesel fuel, purchased electricity, and water will be $\$ 71,000$, and $\$ 4,000$ and $\$ 13,000$ respectively. Taking this same sequential order, annual inflationary rates of $8 \%, 8 \%$, and $7 \%$ have been applied, resulting in the information of Table 9-8.

Lease Costs. Since portions of the transmission pipeline will be crossing private properties, easement lease costs will be incurred. Based on a 30 foot wide easement, 46.5 acres are involved. Annual lease rates of $7 \%$ of the land's $\$ 5000$ per acre market value produced a $\$ 24,0001983$ lease payment schedule in Tables $9-8$ and $9-9$, after an $8 \%$ inflationary trend.

Royalties. Lands at the wellsite are owned in fee by Puna Sugar but with mineral rights reserved to the State. Royalty payments of $10 \%$ of the net 
TABLE 9-8

SYSTEM OPERATING \& MAINTENANCE COSTS $(\$ \times 1000)$

\begin{tabular}{|c|c|c|c|c|c|c|c|}
\hline $\begin{array}{l}\text { ITEM } \\
\text { \& RATE OF } \\
\text { INCREASE } \\
\text { YEAR }\end{array}$ & 7.00 & 8.00 & $\begin{array}{r}3 \\
8.00\end{array}$ & $\begin{array}{r}4 \\
8.00\end{array}$ & $\begin{array}{r}5 \\
8.00\end{array}$ & $\begin{array}{r}6 \\
0.00\end{array}$ & $\begin{array}{l}\text { TOTAL } \\
0 \& \mathrm{M}\end{array}$ \\
\hline $\begin{array}{l}1981 \\
1982 \\
1983 \\
1984 \\
198.5 \\
1986 \\
1987 \\
1988 \\
1989 \\
1990 \\
1991 \\
1992 \\
1993 \\
1994 \\
1995 \\
1996 \\
1997 \\
1998 \\
1999 \\
2000 \\
2001 \\
2002\end{array}$ & $\begin{array}{r}0.000 \\
0.000 \\
13.233 \\
14.159 \\
15.150 \\
16.211 \\
17.346 \\
18.560 \\
19.859 \\
21.249 \\
22.736 \\
24.328 \\
26.031 \\
27.853 \\
29.802 \\
31.889 \\
34.121 \\
36.509 \\
39.065 \\
41.799 \\
44.725 \\
47.856\end{array}$ & $\begin{array}{r}0.000 \\
0.000 \\
4.348 \\
4.696 \\
5.072 \\
5.477 \\
5.915 \\
6.389 \\
6.900 \\
7.452 \\
8.048 \\
8.692 \\
9.387 \\
10.138 \\
10.949 \\
11.825 \\
12.771 \\
13.792 \\
14.896 \\
16.087 \\
17.374 \\
18.764\end{array}$ & $\begin{array}{r}0.000 \\
0.000 \\
70.500 \\
76.140 \\
82.231 \\
88.810 \\
95.914 \\
103.587 \\
111.873 \\
120.822 \\
130.487 \\
140.925 \\
152.199 \\
164.374 \\
177.523 \\
191.724 \\
207.061 \\
223.625 \\
241.515 \\
260.836 \\
281.702 \\
304.238\end{array}$ & $\begin{array}{r}0.000 \\
0.000 \\
390.430 \\
421.664 \\
455.397 \\
491.828 \\
531.174 \\
573.667 \\
619.560 \\
669.124 \\
722.653 \\
780.465 \\
842.902 \\
910.334 \\
983.160 \\
1061.810 \\
1146.750 \\
1238.490 \\
1337.560 \\
1444.560 \\
1560.120 \\
1684.920\end{array}$ & $\begin{array}{r}0.000 \\
0.000 \\
23.835 \\
25.742 \\
27.801 \\
30.025 \\
32.427 \\
35.021 \\
37.823 \\
40.849 \\
44.116 \\
47.646 \\
51.457 \\
55.574 \\
60.020 \\
64.821 \\
70.007 \\
75.607 \\
81.656 \\
88.188 \\
95.243 \\
102.862\end{array}$ & $\begin{array}{r}0.000 \\
0.000 \\
16.640 \\
52.550 \\
83.487 \\
115.978 \\
150.148 \\
186.130 \\
224.070 \\
264.126 \\
306.465 \\
351.273 \\
398.744 \\
449.091 \\
502.547 \\
559.354 \\
619.779 \\
684.139 \\
752.709 \\
825.793 \\
898.042 \\
969.920\end{array}$ & $\begin{array}{r}0.000 \\
0.000 \\
518.986 \\
594.950 \\
669.137 \\
748.328 \\
832.924 \\
923.353 \\
1020.080 \\
1123.620 \\
1234.500 \\
1353.320 \\
1480.700 \\
1617.350 \\
1763.980 \\
1921.410 \\
2090.470 \\
2272.140 \\
2467.380 \\
2677.250 \\
2897.200 \\
3128.550\end{array}$ \\
\hline
\end{tabular}

\section{Legend:}

Item

$\begin{array}{ll}1 & \text { Well Site Water } \\ 2 & \text { Water Tank Electricity } \\ 3 & \text { Well Site Diesel Fuel } \\ 4 & \text { General 0 \& M } \\ 5 & \text { Easement Leases } \\ 6 & \text { Royalties }\end{array}$

Well Site Water

Water Tank Electricity

General 0 \& M

Royalties 
TABLE 9-9

OPERATING AND MAINTENANCE COST COMPONENTS •

\begin{tabular}{|c|c|c|}
\hline YEAR & ITEM & $\begin{array}{l}\text { ANNUAL COST } \\
\text { (DOLLARS) }\end{array}$ \\
\hline \multicolumn{3}{|c|}{ General $0 \& M$} \\
\hline 1978 & Well Site & 176,200 \\
\hline 1978 & Pipeline & 65,200 \\
\hline 1978 & Factory & 24,400 \\
\hline 1978 & Subtotal & 265,800 \\
\hline 1983 & $\begin{array}{l}\text { Total Escalated } \\
\text { Cost (7\% per yr) }\end{array}$ & 372,800 \\
\hline 1978 & Utility (Diesel Fuel) & 48,000 \\
\hline 1983 & $\begin{array}{l}\text { Total Escalated } \\
\text { Diesel Cost }(8 \% \text { per yr) }\end{array}$ & 70,500 \\
\hline 1978 & Utility (Purchased Power) & 3,000 \\
\hline 1983 & $\begin{array}{l}\text { Total Escalated } \\
\text { Power Cost ( } 8 \% \text { per yr) }\end{array}$ & 4,400 \\
\hline 1978 & Utility (Water) & 9,400 \\
\hline 1983 & $\begin{array}{l}\text { Total Escalated } \\
\text { Water Cost ( } 7 \% \text { per yr) }\end{array}$ & 13,200 \\
\hline 1978 & Leases & 16,300 \\
\hline 1983 & $\begin{array}{l}\text { Total Escalated } \\
\text { Lease Cost }(8 \% \text { per yr) }\end{array}$ & 23,900 \\
\hline
\end{tabular}


revenues from geotherma 1 resources have been assessed for this project. Here, net revenues are defined as total system revenues less the sum of the capacity charge, the percentage depletion allowance, the system operating costs and the depreciation. Capacity charge is excluded from this calculation since the generating capacity is presently available and can be utilized with other sources of fuels. Table 9-8 includes the annual royalty payments schedule.

\subsubsection{System Depreciation}

Puna Sugar Company's depreciation guidelines were followed for this study. These guidelines include:

- A combination of declining balance and sum-of-years-digits methods to optimize accelerated depreciation and cash flow.

- An 18 year depreciation period.

- A zero salvage value.

For an 18 year depreciation period, optimum depreciation is achieved by using the declining balance method for two years, then switching to sum-ofyears-digits for the remaining period. The annual depreciation is related in Table $9-10$

It should be noted at this point that of the total well drilling costs, the IDC fraction is expensed and is not depreciated. The remaining well drilling costs are part of the depletable well basis, which is the sum of the estimated resource value and the initial capital improvements value of the well. These latter well drilling costs are not depreciated in the same manner as capital expended for other portions of the project, but are included as part of the annual writeoff for percentage depletion. 
TABLE 9-10

CASH FLOW

(\$X1000)

\begin{tabular}{|c|c|c|c|c|c|c|c|c|c|c|c|c|c|}
\hline YEAR & REVENUES & $\begin{array}{l}\text { DEPLETION } \\
\text { ALLOWANCE }\end{array}$ & $\begin{array}{l}\text { OPERATING } \\
\text { COSTS }\end{array}$ & $\begin{array}{l}\text { INTAN- } \\
\text { GIBLES }\end{array}$ & $\begin{array}{l}\text { DEPRE- } \\
\text { CIATION }\end{array}$ & $\begin{array}{l}\text { TAXABLE } \\
\text { INCOME }\end{array}$ & $\begin{array}{l}\operatorname{TAX} A T \\
49.008\end{array}$ & $\begin{array}{l}\text { TAX } \\
\text { CREDIT }\end{array}$ & $\begin{array}{l}\text { AFTER TAX } \\
\text { INCONE }\end{array}$ & $\begin{array}{l}\text { DEPRE- } \\
\text { CIATION }\end{array}$ & $\begin{array}{l}\text { DEPLETION } \\
\text { ALLOWANCE }\end{array}$ & $\begin{array}{l}\text { INTAN - } \\
\text { GIBLES }\end{array}$ & $\begin{array}{l}\text { CASH } \\
\text { FLOW }\end{array}$ \\
\hline $\begin{array}{l}1981 \\
1982 \\
1983 \\
1984 \\
1985 \\
1986 \\
1987 \\
1988 \\
1989 \\
1990 \\
1991 \\
1992 \\
1993 \\
1994 \\
1995 \\
1996 \\
1997 \\
1998 \\
1999 \\
2000 \\
2001 \\
2002\end{array}$ & $\begin{array}{r}0.00 \\
0.00 \\
3837.67 \\
4117.44 \\
4419.57 \\
1745.88 \\
5098.30 \\
5478.91 \\
5889.96 \\
6333.91 \\
6520.86 \\
7038.68 \\
7597.92 \\
8201.90 \\
8854.21 \\
9558.63 \\
10319.30 \\
11141.10 \\
12028.40 \\
12986.80 \\
14021.80 \\
15139.60\end{array}$ & $\begin{array}{r}0.00 \\
0.00 \\
515.80 \\
565.52 \\
611.84 \\
660.79 \\
713.65 \\
770.74 \\
832.40 \\
898.99 \\
970.91 \\
1048.58 \\
1132.46 \\
1223.06 \\
1320.91 \\
1426.57 \\
1540.67 \\
1663.94 \\
1797.03 \\
1940.79 \\
2096.04 \\
2263.71\end{array}$ & $\begin{array}{r}0.00 \\
0.00 \\
518.99 \\
594.95 \\
669.14 \\
748.33 \\
832.92 \\
923.35 \\
1020.08 \\
1123.62 \\
1234.50 \\
1353.32 \\
1480.70 \\
1617.35 \\
1763.98 \\
1921.41 \\
2090.47 \\
2272.14 \\
2467.38 \\
2677.25 \\
2897.20 \\
3128.55\end{array}$ & $\begin{array}{r}629.86 \\
2720.97 \\
0.00 \\
0.00 \\
0.00 \\
0.00 \\
0.00 \\
0.00 \\
0.00 \\
0.00 \\
0.00 \\
0.00 \\
0.00 \\
0.00 \\
0.00 \\
0.00 \\
0.00 \\
0.00 \\
0.00 \\
0.00 \\
0.00 \\
0.00\end{array}$ & $\begin{array}{r}13.02 \\
1223.51 \\
2287.08 \\
2089.82 \\
1963.08 \\
1836.34 \\
1709.50 \\
1582.87 \\
1456.13 \\
1329.39 \\
1202.65 \\
1075.91 \\
949.18 \\
822.44 \\
695.70 \\
568.96 \\
142.22 \\
315.48 \\
188.75 \\
6.62 .69 \\
0.00 \\
0.00\end{array}$ & $\begin{array}{r}-642.88 \\
-3944.48 \\
515.80 \\
866.15 \\
1175.51 \\
1500.42 \\
1842.12 \\
2201.94 \\
2581.35 \\
2981.91 \\
3112.80 \\
3560.87 \\
4035.58 \\
4539.05 \\
5073.62 \\
5641.68 \\
6245.93 \\
6889.53 \\
7575.24 \\
8306.01 \\
9028.56 \\
9747.29\end{array}$ & $\begin{array}{r}-231.48 \\
-1566.95 \\
252.74 \\
424.41 \\
576.00 \\
735.21 \\
902.64 \\
1078.95 \\
1264.86 \\
1461.13 \\
1525.27 \\
1744.82 \\
1977.43 \\
2224.13 \\
2486.07 \\
2764.12 \\
3060.50 \\
3375.86 \\
3711.86 \\
4069.94 \\
4423.99 \\
4776.17\end{array}$ & $\begin{array}{r}172.86 \\
4860.28 \\
0.00 \\
0.00 \\
0.00 \\
0.00 \\
0.00 \\
0.00 \\
0.00 \\
0.00 \\
0.00 \\
0.00 \\
0.00 \\
0.00 \\
0.00 \\
0.00 \\
0.00 \\
0.00 \\
0.00 \\
0.00 \\
0.00 \\
0.00\end{array}$ & $\begin{array}{r}-238.54 \\
2482.74 \\
263.06 \\
441.74 \\
599.51 \\
765.22 \\
939.48 \\
1122.99 \\
1316.49 \\
1520.78 \\
1587.53 \\
1816.05 \\
2058.15 \\
2314.92 \\
2587.55 \\
2877.26 \\
3185.43 \\
3513.67 \\
3863.38 \\
4236.07 \\
4604.57 \\
4971.12\end{array}$ & $\begin{array}{r}13.02 \\
1223.51 \\
2287.08 \\
2089.82 \\
1963.08 \\
1836.34 \\
1709.60 \\
1582.87 \\
1456.13 \\
1329.39 \\
1202.65 \\
1075.91 \\
949.18 \\
822.44 \\
695.70 \\
568.96 \\
442.22 \\
315.48 \\
188.75 \\
62.69 \\
0.00 \\
0.00\end{array}$ & $\begin{array}{r}0.00 \\
0.00 \\
515.80 \\
566.52 \\
611.84 \\
660.79 \\
713.65 \\
770.74 \\
832.40 \\
898.99 \\
970.91 \\
1048.58 \\
1132.46 \\
1223.06 \\
1320.91 \\
1426.57 \\
1540.67 \\
1663.94 \\
1797.03 \\
1940.79 \\
2096.04 \\
2263.71\end{array}$ & $\begin{array}{r}629.86 \\
2720.97 \\
0.00 \\
0.00 \\
0.00 \\
0.00 \\
0.00 \\
0.00 \\
0.00 \\
0.00 \\
0.00 \\
0.00 \\
0.00 \\
0.00 \\
0.00 \\
0.00 \\
0.00 \\
0.00 \\
0.00 \\
0.00 \\
0.00 \\
0.00\end{array}$ & $\begin{array}{r}404.34 \\
6427.22 \\
3065.93 \\
3098.07 \\
3174.42 \\
3262.34 \\
3362.73 \\
3476.59 \\
3605.01 \\
3749.15 \\
3761.08 \\
3940.54 \\
4139.78 \\
4360.41 \\
4604.15 \\
4872.79 \\
5168.32 \\
5493.09 \\
5849.15 \\
6239.54 \\
6700.61 \\
7234.83\end{array}$ \\
\hline
\end{tabular}




\subsubsection{Tax and Tax Incentives.}

Accommodations must be made for taxes and tax incentives to obtain a practical evaluation of economic feasibility.

Income Tax. In recent years, Puna Sugar has paid tax levies of $49 \%$ of taxable income. That rate is maintained in this project.

Minimum Taxes. Under certain conditions, the taxpayer is accorded preferential tax treatment. However, there are requirements for payment of minimum taxes on these preference items. In this project, two tax preference situations, excess IDCs and excess percentage depletion, apply.

- Excess IDCs. Whenever IDCs are expended, excess IDCs are a tax preference item and are subject to a minimum tax. Excess IDCs are computed by subtracting two items from the base IDC. The first is one year's depreciation of the base IDC, calculated on a 10 year straight line basis. The second item is any net income from the property for which the IDCs are being expended.

- Excess Percentage Depletion. The other tax preference item that applies to this project is the excess of percentage depletion above what would be the allowable cost depletion for that year, on an adjusted basis. In the case of this project, there are no operating wells with long term operation in the vicinity that could serve as a yardstick in predicting the cost basis for a new well. With that consideration, it is assumed for analysis purposes that there is no excess percentage depletion. Once such a project is placed in operation, though, an adjusted cost depletion basis must be computed annually to determine whether or not minimum taxes are to be paid. 
The minimum tax is $15 \%$ of the total tax preference items less the greater of (1) $50 \%$ of income tax liability or (2) $\$ 10,000$. This minimum tax is added to the usual income tax liability. The minimum tax on excess IDCs wi11 be $\$ 83,500$ in 1981 and $\$ 365,800$ in 1982 . Total taxes for 1981 through 2002 are exhibited in Table 9-10.

Tax Credits. There are two tax credits that are applicable to the proposed project:

- Business Investment Tax Credit, a $10 \%$ credit on capital investment.

- Specially Defined Energy Property Tax Credit, an additional 10\% tax credit.

These tax credits are combined and then applied to the capitalized portions of project costs. IDCs do not qualify for tax credit. In 1981 the tax credits total $\$ 173,000$ and in $1982 \$ 4,860,000$ as indicated in Table 9-10.

Intangible Drilling Costs (IDCs). Under the Energy Tax Act of 1978, geothermal energy developers can elect to expense or capitalize IDCs. When expensed, IDCs are subject to the minimum tax as described in the preceding section on minimum taxes. The expensing of IDCs amounts to $\$ 630,000$ in 1981 and $\$ 2,721,000$ in 1982 as noted in Table 9-10.

Percentage Depletion Allowance. The Energy Tax Act of 1978 allows geothermal energy producers to select between two means of depreciating the geothermal resource and capital well assets. Prior to 1978 only cost depletion, which is based on actual or estimated geothermal reserve value and capital assets, was deductible. Percentage depletion based upon revenues from the geothermal assets can now be deducted. The percentage allowance schedule 
is presented in Table 9-11.

Percentage depletion in excess of the cost depletion basis is an item of tax preference subject to the minimum tax. In any year, percentage depletion is limited to $50 \%$ of the taxable income from the producing property. In this calculation, taxable income is computed without the deduction for depletion. Table 9-10 shows the percentage depletion for each year of the project.

\subsubsection{Analysis with Discounted Cash Flow Method}

The economic feasibility of the proposed project was evaluated using the discounted cash flow method. Revenues, system operating costs, depreciation, depletion allowances, intangible drilling costs, taxes and tax credits were combined to form a cash flow model for the project as developed in Table 9-10. The cash flow schedule is listed in Table 9-12. Cash requirements were tabulated and its NPV computed at a cash requirement discount rate of $12 \%$. Table $9-12$ indicates the cash requirements, cash requirement discount factors, NPV of cash requirements, cash flows, cash flow discount factors, and NPV of cash flows, all evaluated from the beginning of 1981 . Through the use of an iterative procedure on a computer, the cash flow discount rate (ROI) for the project was found to be $15.1 \%$.

\subsection{PUBLIC BENEFITS}

A very important aspect of this project is the public benefit, which is primarily reflected in economic terms. These benefits accrue from geothermal royalties, new spending, adjusted electric rates, and fuel oil savings. At least $\$ 79,000,000$ in direct benefits will accumulate for the general public as a result of this project. 
TABLE 9-11

PERCENTAGE DEPLETION ALLOWANCE SCHEDULE

\begin{tabular}{|cc|}
\hline Year & Per Cent Depletion \\
\hline 1978 thru 1980 & 22 \\
1981 & 20 \\
1982 & 18 \\
1983 & 16 \\
1984 and thereafter & 15 \\
\hline
\end{tabular}


TABLE 9-12

DISCOUNTED CASH FLOW \& CASH REQUIREMENTS

$(\$ \times 1000)$

\begin{tabular}{|c|c|c|c|c|c|c|}
\hline YEAR & $\begin{array}{l}\text { OPERATING } \\
\text { CASH ELOW }\end{array}$ & ${ }_{15} F_{064}^{A T}$ & $\begin{array}{l}\text { D I SSCOUNTED } \\
\text { VALUE }\end{array}$ & $\begin{array}{l}\text { CASH } \\
\text { REQUIREMENTS }\end{array}$ & $D_{12}: 00008$ & DISÇOUNTED \\
\hline $\begin{array}{l}1981 \\
1982 \\
1983 \\
1984 \\
1985 \\
1986 \\
1987 \\
1988 \\
1989 \\
1990 \\
1991 \\
1992 \\
1993 \\
1994 \\
1995 \\
1996 \\
1997 \\
1998 \\
1999 \\
2000 \\
2001 \\
2002\end{array}$ & $\begin{array}{r}404.34 \\
6427.22 \\
3065.93 \\
3098.07 \\
3174.42 \\
3262.34 \\
3362.73 \\
3476.59 \\
3605.01 \\
3749.15 \\
3761.08 \\
3940.54 \\
4139.78 \\
4360.41 \\
4604.15 \\
4872.79 \\
5168.32 \\
5493.09 \\
5849.15 \\
6239.54 \\
6700.61 \\
7234.83 \\
\text { TOTALS }\end{array}$ & $\begin{array}{l}0.9322 \\
0.8102 \\
0.7041 \\
0.6119 \\
0.5318 \\
0.4622 \\
0.4017 \\
0.3491 \\
0.3034 \\
0.2637 \\
0.2291 \\
0.1991 \\
0.1731 \\
0.1504 \\
0.1307 \\
0.1136 \\
0.0987 \\
0.0858 \\
0.0746 \\
0.0648 \\
0.0563 \\
0.0490\end{array}$ & $\begin{array}{r}376.94 \\
5207.28 \\
2158.78 \\
1895.82 \\
1688.22 \\
1507.83 \\
1350.75 \\
1213.65 \\
1093.72 \\
988.54 \\
861.85 \\
784.76 \\
716.50 \\
655.88 \\
601.87 \\
553.60 \\
510.30 \\
471.36 \\
436.20 \\
404.39 \\
377.42 \\
354.16 \\
24209.80\end{array}$ & $\begin{array}{r}1494.14 \\
27022.30 \\
0.00 \\
0.00 \\
0.00 \\
0.00 \\
0.00 \\
0.00 \\
0.00 \\
0.00 \\
0.00\end{array}$ & $\begin{array}{l}0.9449 \\
0.8437 \\
0.7533 \\
0.6726 \\
0.6005 \\
0.5362 \\
0.4787 \\
0.4274 \\
0.3816 \\
0.3407 \\
0.3042 \\
\text { TOTALS }\end{array}$ & $\begin{array}{r}1411.83 \\
22797.92 \\
0.00 \\
0.00 \\
0.00 \\
0.00 \\
0.00 \\
0.00 \\
0.00 \\
0.00 \\
0.00 \\
24209.75 \\
\end{array}$ \\
\hline
\end{tabular}

\begin{tabular}{l} 
PV OF AFTER TAX CASH FLOW AT 15.0644 \& DISCOUNT RATE $=$ \\
LESS PV OF CASH REQUIREMENTS AT 12.0000 \& DISCOUNT RATE $=$ \\
\hline
\end{tabular}

NET PRESENT VALUE OF PROJECT

0.05 


\subsubsection{Geothermal Mining Leases and Royalties}

Provisions within Regulation 8 of the State Department of Land and Natural Resources dictate annual payments for geothermal mining leases. Should the geothermal resources be utilized, royalties are also assessed, but the royalties are credited against the annual geothermal mining leases. These payments enter the State General Fund, and is distributed to the populace in various forms. Table 9-13 lists the annual royalties generated from the project, which in total, exceeds $\$ 8,000,000$.

\subsubsection{Operating and Maintenance Expenditures}

The project will require new expenditures in the form of $0 \& M$ costs. These new monies enter the economy creating additional state personal income, and to some extent is supplemented by the fuel oil expenditure savings which may also enter the State's economy. It must be emphasized that the new $0 \& M$ costs are fundamentally domestic and local in nature. Little of that expenditure will fuel foreign economies.

Implicitly evident in the $0 \& M$ effect is the creation of new semi-skilled and skilled jobs. A permanent staff of 9.5 persons will be required by the project. Other studies have indicated that for every full time employee in the sugar industry, approximately 2.3 other persons are employed in related support capacities. Thus, a total of 32 permanent jobs are expected to be required in the State economy as a result of this project.

It is difficult to ascertain the economic multiplier of $0 \& \mathrm{M}$ expenditures themselves, especially with the influencing factor of fuel oil spending reductions, but the project should result in a net state personal income increase. Evaluation of the multiplier effect extends beyond the work limits 
TABLE 9-13

ACCUMULATED PUBLIC BENEFITS FROM THE PROJECT

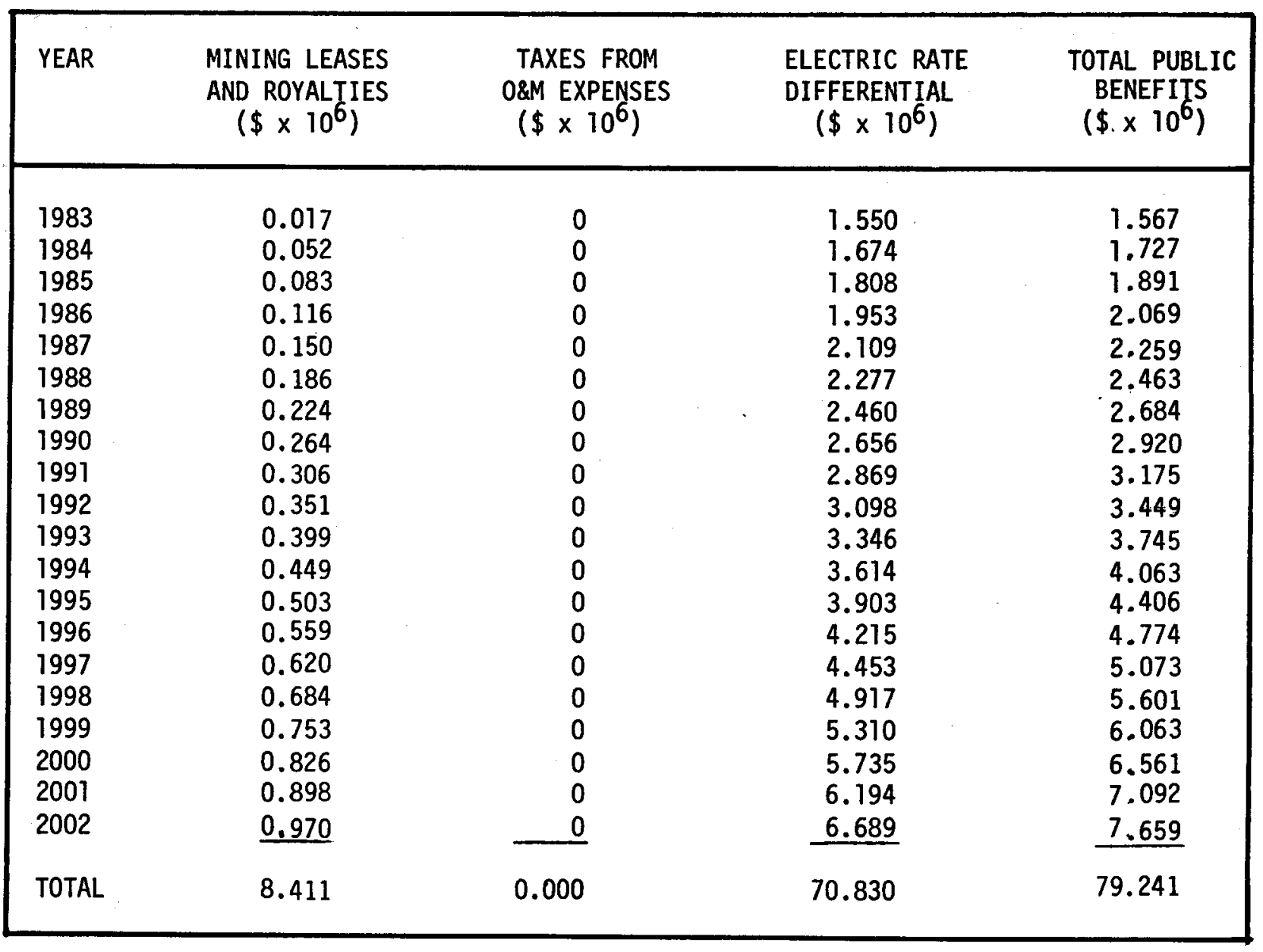


of this study and has not been attempted. Since a dollar value has not been determined for the effect of 0 \& $M$ costs, income taxes accruing to the State as a result of operating and maintenance expenditures have not been included in Table $9-13$.

\subsubsection{Electric Rates}

Perhaps the most significant impact this project will have on the economy will be felt in the electric rates. While the project will not lower the price of electricity, it will help maintain a lower rate structure than could be afforded with fossil fuel generated power.

Implementation will allow HELCO to postpone immediate additional generating capacity. By 1983, busbar HELCO generating costs from a new fossil fueled power plant is estimated to be 66 mills per kWh. In contrast, this study indicates that Puna Sugar power sales will be approximately 41 mills per kWh, including capacity charge. Based on an increased annual sale of $62,000,000 \mathrm{kWh}$, the yearly gross savings to the public in 1983 electricity charges will be about $\$ 1,550,000$, as related in Table 9-13. This will escalate to $\$ 6,690,000$ annually by the last year of the project and over a 20 year life, the total accrued savings to the public will be approximately $\$ 71,000,000$.

\subsection{ALTERNATIVE METHODS OF FINANCING}

Several alternative methods of financing are available to projects of this nature. In the following discussion, the salient features of the more usual alternative methods are addressed. However, it is not within the scope of this study to determine the type of financing approach that should be taken. Such a determination would be made during the evaluation and project financing negotiation phases of the project. 


\subsubsection{DOE Geothermal Loan Guarantee Program}

The DOE Geothermal Loan Guarantee Program was enacted by Congress to stimulate commercial development of geothermal resources. The program minimizes financial risk to lenders by providing government insurance for $75 \%$ of a loan in case of default. Basically, it is federally guaranteed. leveraged financing. Features of the program are:

- The loan amount covered by this program is $\$ 50$ million per project and $\$ 100$ million per borrower. Twenty-five per cent of the equity must be provided and committed by the borrower.

- The duration of the loan may be up to 30 years with interest rate and loan fees negotiated between the borrower and lender. Only the assets associated with the project are collateralized.

- A guarantee fee of $1 \%$ on the remaining balance of the guarantee loan is imposed.

\subsubsection{Leveraged Leasing}

This form of financing is similar to the preceding method except in this situation, rather than being the borrower, Puna Sugar would be the lessee. There would be an equity investor (the lessor) who provides a portion of the equity and borrows the rest. The lessor and lender would very likely apply under the Geothermal Loan Guarantee Program since the project ROI is not sufficiently high for any lender to assume the full risk of the project.

\subsubsection{Tax Exempt Industrial Development Bonds}

In 1978, the State Constitutional Convention proposed and the electorate adopted the principle of special purpose revenue bonds. County and State governments can now issue tax exempt industrial development bonds for private interests such as Puna Sugar. These bonds are excluded from the 
debt limits of the State or County and do not make any real or implied use of the government credit. The interest and principal payments on the bonds are paid by the private development firm when they become due. The real incentive of these loans is the tax exempt status which they enjoy, which translates into lower loan interest.

\subsubsection{Government Ownership}

In private enterprise, a minimum acceptable profit must be achievable for project financing and implementation. In this particular project, the majority of capital expenditure is for the steam transmission pipeline. The pipe's sole purpose is to deliver the resource to the factory where it can be used. In itself it is not generating any income, yet it must produce a return on investment. More than any other single reason, the pipeline cost is the cause of depressed profitability prospects from the project.

Any argument on profitability almost inevitably introduces the possibility of government ownership. Here, the question of project return-on-investment is mute, the only requirements are $0 \& M$ cost coverage and debt retirement. Over and above this primary reason, however, several specific advantages can be established for government pipeline ownership.

- Ready longitudinal pipeline access to all public highway rights-of-way in the area.

- Access to the condemnation process in private land acquisition for rights-of-way.

- Establishment of a general energy corridor through which steam and hot brines can be transmitted not only to Puna Sugar, but to other potential users is possible. The siting 
of an industrial park near Keaau has been prominently mentioned for manganese nodule refining, and other new uses for the steam and brine are possible. With co-usage of the resources, the economics of scale are clearly evident.

- The electric cost saving and tax revenue benefits from the Puna Sugar project alone are appreciable to the public, and in themselves argue well for government assistance in the project implementation.

- Government may be in a better position to accept the risks associated with the development and operation of parts of the project.

Government ownership of the steam pipeline introduces several other bonding options to this project. As with the case of the industrial development bonds, bond interest to the investor is tax exempt, with the effect being a lowering of the capital recovery requirement. The risks inherent in this kind of venture, however, may have a negative effect on the bond rating of the government agencies. Government financing through various bond options are covered in the following subsections. In each following case, reference is made to the State but similar provisions and conditions apply to the County as well.

General Obligation (GO) Bonds. The issue of this type of bond is backed by the full faith and credit of the State. Section 47-5 of the Hawaij Revised Statutes requires that debt obligations be fulfilled first from the State's revenues. This provision of preference makes the GO bonds the most secure of the bond options, and therefore, commands the lowest interest rate.

General obligation bonds may be issued by the State when authorized by 
majority vote of both legislative houses. There is a restriction in this type of financing, as the debt ceiling by mid-1982 will be limited to $18.5 \%$ of the average State general fund revenues.

Revenue Bonds. Revenues from the project are used to pay the principal and interest on this bond. Interest rates are based on the user's credit rating and the risk involved in the project.

Reimbursable GO Bonds. The features of both revenue bonds and GO bonds are available in the reimbursable GO bond. With this type of bond, the State general fund is reimbursed from project revenues for all or part of the principal and interest. 


\section{REFERENCES}

9-1 Cheeks, James E., Editor-in-Chief, Federal Tax Coordinator 2d, Vol. 18, New York: The Research Institute of America, Inc., 1978.

9-2 Silverstein, Leonard L., Chief Editor, Tax Management Portfolios: Mineral Properties--Exploration, Acquisition, Developtment and Disposition, Vol. 15, 4th Ed., Washington, D.C.: Tax Management, Inc. Div. of the Bureau of National Affairs, Inc., 1973.

9-3 Silverstein, Leonard L., Chief Editor, Tax Management Portfolios: Minimum Tax--Computation and Application, Vol 288, 2nd Ed., Washington, D.C.: Tax Management Inc. Div. of the Bureau of National Affairs, Inc., 1977.

9-4 Silverstein, Leonard L., Chief Editor, Tax Management Portfolios: Minimum Tax--Items of Tax Preference, Vol. 269, 2nd Ed., Washington, D.C.: Tax Management Inc. Div. of the Bureau of National Affairs, Inc., 1977.

9-5 Silverstein, Leonard L., Chief Editor, Tax Management

Portfolios: Mineral Properties Other Than Gas and 0il--Operation, Vol. 90, 5th Ed., Washington, D.C.: Tax Management Inc. Div. of the Bureau of National Affairs, Inc., 1974.

9-6 Energy Tax Act of 1978--Conference Report, Report No. 95-1324, 95th Congress, 2d Session, October $11,1978$.

9-7 Geothermal Loan Guaranty Program, Unpublished booklet by Bank of Montreal (California) and Merrill, Lynch, Pierce, Fenner \& Smith, Inc.

9-8 Rodzianke, Pau1, Overview of and Introduction to Geotherma 1 Power Plant Financing Options, (Proceedings) A Conference on the Commercialization of Geothermal Resources. Geothermal Resources Counci1, Davis, CA., Nov. 1978, pp 35-38.

9-9 Beim, David 0., "Project Financing of Geothermal Development," (Proceedings) A Conference on the Commercialization of Geothermal Resources, Geothermal Resources Council, Davis, CA., Nov. 1978, pp. 43-44. 
9-10 Stephens, Randa11 C., "Geothermal Energy Legislation: The National Energy Act and New Proposals," (Proceedings) A Conference on the Commercialization of Geothermal Resources, Geothermal Resources Council, Davis, CA., Nov. 1978, pp.45-48.

9-11 Woods, John H., Structuring of Geothermal Development Loans," (Proceedings) A Conference on the Commercialization of Geothermal Resources, Geothermal Resources Council, Davis, CA., Nov. 1978, pp. 51-54.

9-12 Penawek, Gregory, "Leveraged Leasing. of a Geothermal Power Plant," (Proceedings) A Conference on the Commercialization of Geothermal Resources, Geothermal Resources Council, Davis, CA., Nov, 1978, pp. 55-58.

9-13 Eisenstat, Samuel M., "Federal Tax Treatment of Geothermal Exploration and Production, (Proceedings) A Conference on the Commercialization of Geothermal Resources, Geothermal Resources Council, Davis, CA., Nov. 1978, pp. 61-64.

9-14 Feasibility Study of Resource Recovery from Solid Waste, Prepared by W. A. Hirai and Associates for County of Hawaij, Hilo, Hawaii, May, 1977.

9-15 Feasibility of Power Generation from Solid Wastes on Oahu, Prepared by Sunn, Low, Tom, \& Hara, Inc. for Amfac, $C$ and $C$ of Honolulu, and HECO, Honolulu, Hawaii, February, 1975.

9-16 Study of Financing Alternatives for Solid Waste Management, Prepared by White, Weld \& Co. for State of Hawaii and $C$ and C of Honolulu, New York, N. Y., April, 1977.

9-17 Hitch, T. K., How the Collapse of the Sugar Industry Would Impact on Hawaij's Economy, First Hawaiian Bank, June, 1978. 
Section 10

ENVIRONMENTAL CONCERNS

The natural resources of the County of Hawaii are those physical factors in the environment which are recognized as useful, valuable or desirable to civilization. For the island, these are fundamentally land, water and air, and include geologic features, soils, the shoreline, flora, and fauna.

Environmental impacts are a function of the degree, magnitude and specific application of the geothermal resources. While specific projects individually may affect the environment quite nominally, the cumulative effect of several applications may be quite significant. The general development of geothermal resources in the East Rift Zone will have an environmental impact on the Puna district, as well as upon the specific sites and pipeline corridors selected. An evaluation of this magnitude is beyond the scope of the current project and henceforth, discussion will be limited to the particular project being studied. This section will assess the consequences of implementation and investigate the potential mitigating measures for adverse impacts that cannot be avoided.

\subsection{PROJECT DESCRIPTION}

The proposed system generally incorporates three separate sections. Figure 10-1 represents a highly simplified schematic which depicts these sections as well site facilities, resource transmission, and the factory retrofit. 


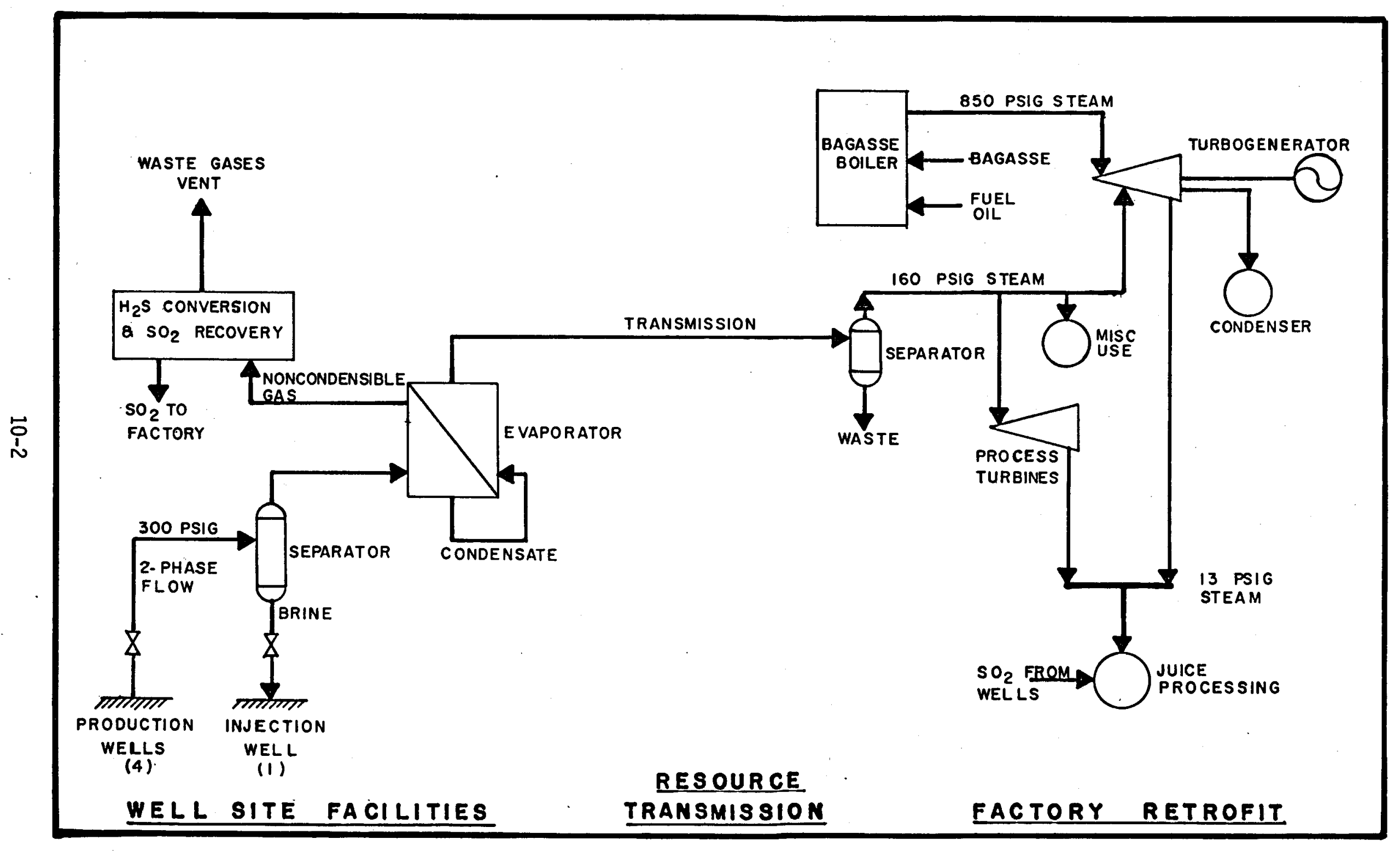

Figure 10-1

Simplified Proposal Schematic

$C$ 


\subsubsection{Well Site Facilities}

The resource is assumed to be developed in the East Rift Zone, near the successful HGP-A well. Data developed from the HGP-A well is adapted and used as the basis for resource design. As many as four production wells producing two phase flow at 300 psig will operate and flow into a common separator. Brines are immediately reinjected into the ground and the geothermal steam enters evaporators whose primary function is to separate the noncondensible gases from the steam. Developed condensates enter the liquid side of the evaporators as feed water for clean steam production at 240 psig. Noncondensible gases are processed after being vented out of the evaporators. The gas processing results in oxidation of odorous hydrogen sulfide $\left(\mathrm{H}_{2} \mathrm{~S}\right)$ to sulfur dioxide $\left(\mathrm{SO}_{2}\right)$. This $\mathrm{SO}_{2}$ is then recovered for eventual use in the Puna Sugar cane juice processing.

\subsubsection{Resource Transmission}

The clean steam from the evaporators is transmitted approximately 16 miles to the factory site through a 20 -inch diameter insulated pipe. Approximately 11 miles of the distance can be traversed at ground level. The remaining length of nearly five miles must be placed in concrete pipe trenches along road shoulders that pass through residential subdivisions.

\subsubsection{Factory Retrofit}

Presently, bagasse and fuel oil are used to generate $850 \mathrm{psig}$ steam. This steam enters a double automatic extraction-condensing turbogenerator. Process steam at $160 \mathrm{psig}$ and $13 \mathrm{psig}$ is extracted from the turbine for factory demands with the remaining steam condensed. During processing periods, approximately 10.5 MW are generated, with $4.5 \mathrm{MW}$ being consumed by in-plant 
demands and the remaining 6 MW being sold to the public utility.

At the factory site, retrofitting will primarily involve modifications to the turbogenerator. Steam entering the factory from the well site passes through a separator and is introduced to the 160 psig process system. This geothermal steam replaces the extracted bagasse fired steam and allows that steam to remain in the turbogenerator and pass to the condenser. As more steam of geothermal origin enters the process, less fuel oil is required to satisfy sugar factory thermal needs. At some point fuel oil usage during normal process periods can be eliminated. In fact, the 160 psig extraction process can be reversed to admit steam into the turbine, raising the electrical output of the turbogenerator. At least $12.32 \mathrm{MW}$ can be exported to the utility, with a factory supply of about 162,200 pounds steam per hour from the goethermal well site. The income from this increased export schedule, the near elimination of fuel oil purchase and other geothermal related benefits offset the costs of the geothermal system.

\subsection{THE NATURAL ENVIRONMENT}

The implementation of this project will influence to varying degrees, several aspects of the natural environment. The following subsections address these aspects.

\subsubsection{Physiography}

The Puna District as shown in Figure $10-2$, is one of nine judicial districts on the Island of Hawaii, which collectively comprise the County of Hawaii. The area encompasses nearly 500 square miles $(317,000$ acres $)$, or $12.7 \%$ of the island's 4038 square mile surface.

The district is located on the southeastern shield of Kilauea and on the 


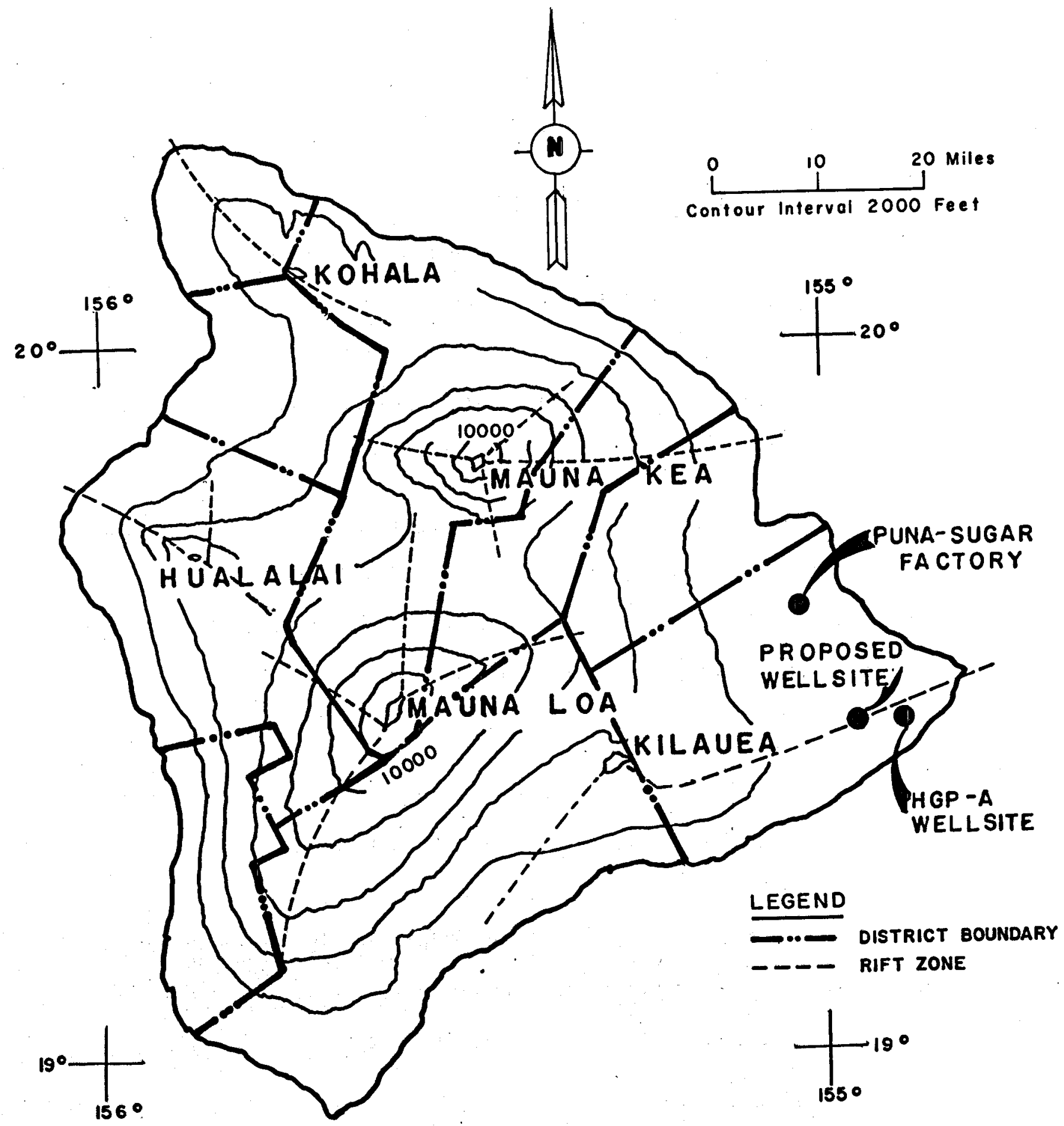

Figure $10-2$

Island of Hawai 
eastern slope of Mauna Loa mountain. It extends from the rocky seacoasts to the lush rain forests at 5000 feet elevation. Within this region, barren lava flows from recent volcanic eruptions cross and contrast with older flows that have been reclaimed by vegetation.

Most of the area consists of undissected lands, a reflection of the district's recent volcanic origin, which has not allowed much erosional activity. Slopes are gradual in the southeasterly to northeasterly directions as depicted in Figure 10-2. A notable exception to the predominantly flat terrain is a chain of pit craters, cinder cones, ramparts, and spatter cones which delineate the East Rift Zone of Kilauea.

In spite of the high rainfall in the area, there are no perennial streams. The area is generally characterized by a lack of defined watercourses. The small gulches that do exist originate in the uplands and are normally dry. Runoff consistently percolates into the porous lava before reaching the lower coastal areas.

The shore line in the district is characterized as cliffed and uncliffed. Black sand beaches, formed by surface hydrothermal fracture of molten lava and ocean wave erosion, appear in some coves as a result of transport by the offshore ocean currents. Their locations are irregular in pattern and widely spaced. In addition, brackish water and tidal pools dot the shoreline and are noted features of natural beauty.

\subsubsection{Geology and Soils}

The island is formed by five volcanoes and is of very recent geologic origin. Of the five, the two northern most, Kohala and Mauna Kea are extinct. Hualalai, to the west, last erupted in 1801 and is considered 
dormant. The remaining two, Mauna Loa and Kilauea, are classic shield volcanoes, and are among the world's most active volcanoes. Kilauea has erupted 10 times since 1970, last being active in November, 1977 . It is the volcanic activity of these two mountains that have formed the plain of the Puna district, first with the shield flows from Mauna Loa, and more recently from Kilauea.

Rocks in the district are completely volcanic in origin, being primarily tholeiitic basalts characteristic of shield volcanoes. A more detailed stratigraphic description of the geology pertaining to the East Rift Zone appears in Section 4 .

Soils in the district are predominately shallow, but oftentimes productive. More than half of the area is covered by histosols, organically formed soils that commonly occur on geologically recent lava flows. In the west central area of the district is a tract of entisols on which lush vegetation has developed. Miscellaneous other soils are found in isolated pockets throughout the district.

The project will not significantly influence the geology and soils of the area. Small disturbances will inevitably occur to accommodate new facilities necessary for the incorporation of the project. These will not produce visible change for the area in general.

\subsubsection{Hydrology}

Surface waters in the district are virtually nonexistent, due to the high permeability of the ground. Small gulches which originate in the higher elevations are normally dry. Runoff percolates into the porous lava or is evaporated before reaching the lower coastal area. A few tidal pools, 
however, exist near the coast line.

The ground water of the area has not been defined in detail, primarily because it has not been economically necessary. The high rainfall commonly provides an adequate supply of water to the district's main economic base, agriculture. However, some generalized statements can be made.

A small portion of the water is confined at elevated levels by the relatively impermeable dikes of the East Rift Zone. South of the East Rift Zone, fresh water occurs as a broad lens-shaped body at sea level, floating on a denser salt water base. Near the shoreline, where the lens is thinnest, there is intermixing of the fresh and salt waters, producing a zone of brackish water.

North of the East Rift Zone, rainfall is much greater. Possibly as much as 2300 million gallons per day percolate to the fresh water basal reservoir, producing a very deep lens. At the Puna Sugar factory, this fresh water compartment has been estimated to be more than 800 feet thick.

Potable water is supplied to users by individual catchment systems and by four major well systems, the 0laa-Mountain View, Pahoa, Kapoho, and Kalapana systems. Each of the major water systems is under the jurisdiction of the County Department of Water Supply.

No major effect is realized on the hydrology of the district by the project. Minimal amounts of potable water from the Pahoa water system will be used at the wellsite, and these demands are well within the capacity of the present system. 
A number of effluents must be released at the well site, the major effluent being the separated brines from the liquid dominated well flows. These are immediately piped to a reinjection well which returns the brines to the hydrothermal producing depths. A careful casing and cementing schedule will prevent leakage of geothermal brines into any possible existing acquifers.

Wellsite process discharges such as cooling tower blowdown will be directed to a percolation pond, and these will be allowed to percolate into the very permeable ground. Flows are minimal, and considering the high rainfall of the surrounding area, significant influence on ground water is not expected.

Sanitary waste disposal in the district is normally accomplished by cesspools and this will be the method used for the project at the wellsite.

\subsubsection{Meteorology}

The district, directly facing the persistant northeasterly tradewinds, is characterized by abundant rainfall caused by its location. Rainfall over the ocean areas near the island averages 25 to 30 inches per year. However, rain forms as the moist tradewinds ascend and traverse the landscape. The mean distribution of these rains resemble the contour of the terrain, with less than 75 inches falling on some seacoasts and more than 200 inches precipitating annualiy in the upper elevations of the district. Average rainfall for the area is 150 to 175 inches per year, with relatively slight seasonal differences.

Temperatures are mild throughout the year, averaging between $75^{\circ}$ and $80^{\circ}$ $F$ in the project area. Relative humidity ranges from $65 \%$ to $90 \%$ and is normally confined by an atmospheric temperature inversion layer, oftentimes 
located at approximately 4000 feet elevation.

The prevailing wind is the northeasterly trade wind, with the winds more persistent during summer than in winter. Frequency of winds range from a minimum of $50 \%$ in January to over $90 \%$ in July, averaging about $70 \%$ on an annual basis. Well exposed areas of the district are subjected to winds averaging 15 miles per hour.

Due to tradewinds, cumulus clouds cover much of the district's slopes. As with the orographic rainfall pattern, the clouds are formed from the ascending moist marine air. Consequently, clouds are more frequent and extensive in the higher elevations of the west. Nearby, Hilo provides an indication of the extent of this cloud cover. Skies there are clear (sky cover 0.3 or less) only eight per cent of the time and cloudy (sky cover 0.8 or more) 58 per cent of the time.

\subsubsection{Chemical Toxicants in the Air, Water and Soil}

The HGP-A well head generator project is located approximately 3.5 miles from this study's proposed wellhead and processing site. An environmental impact statement (EIS) has been produced for the HGP-A project and much of that data is appropriate for this work, since the natural environment is very similar, if not identical. The section of the EIS relating to chemical toxicants has been reproduced below in its entirety.

Particular attention must be given to ascertaining if the chemicals commonly found in geothermal water or steam pose a threat to the environment. From May 1975 to date [1978], the environs of HGP-A have been tested for mercury and toxic gases, particularly the sulfur compounds known to be emitted in geo- 
thermal areas. With respect to the fixed gases, $\mathrm{SO}_{2}$ and $\mathrm{H}_{2} \mathrm{~S}$, there has been no evidence of change from pre-drilling through recent flashing experiments (Table 10-1). These values have been consistently at or below detection thresholds and well under hazardous levels in spite of the proximity ( 25 miles) of natural vents in the Volcanoes National Park which supply these sulfurous gases continuously. In these fumarole areas, the measurement during 1971-76 yielded peak values as high as $25 \mathrm{ppm}$ for $\mathrm{SO}_{2}$ and $5 \mathrm{ppm}$ for $\mathrm{H}_{2} \mathrm{~S}$. These toxic emissions apparently reach the HGP drill site area only infrequently and for brief periods. Their lack of persistence may be an important environmental consideration. Aside from convective and wind dispersal processes, these gases may be oxidized both photochemically and biochemically to sulfates, and the capacity both of soil microorganisms and vegetation for metabolizing these sulfur gases may contribute to ecological "detoxification."

The same consideration cannot be applied to mercury. It is a potential toxicant in any form, al though more so in elemental and alkyl forms. Various figures have been cited for maximum allowable air mercury. Schroeder has suggested an 8 hour occupational 1 imit of $10 \mathrm{ug} / \mathrm{m}^{3}$ but recommends no more than $0.1 \mathrm{ug} / \mathrm{m}^{3}$ for continuous exposure of the popluation at large. Applying a provisional Federal exposure value of $1 \mathrm{ug} / \mathrm{m}^{3}$ as a reference figure, it is obvious from Table 10-1 that HGP drill site levels were at threshold up to the - flashing experiment, but it is also clear that up to the 22 July 1976 flashing, the mercury levels were area values 
TABLE $10-1$

CHEMICAL TOXICANTS AT THE

HAWAII GEOTHERMAL PROJECT WELL

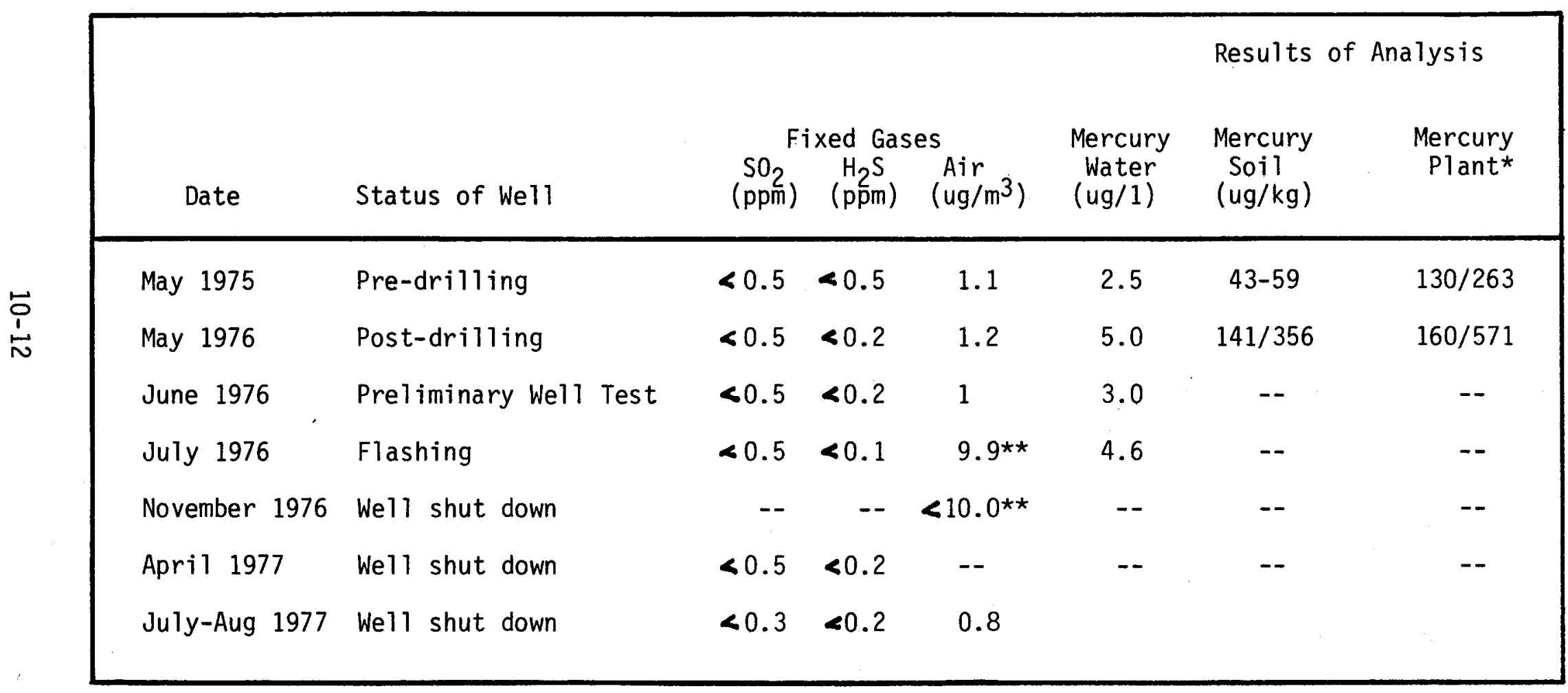

* Nutgrass within $50 \mathrm{~m}$, Ohia-fert at ca. $100 \mathrm{~m}$ distance

** These high values for mercury, with the well shut-in, seems to reflect elevated activity along the East Rift with the formation of new emission centers, such as Heiheiahulu, rather than emissions from the well. 
not related to drill site operations. Hawaiian thermal areas are essentially like those elsewhere in the world with respect to mercury in air, water, soil and plants (Table 10-2), with norms tending to be appreciably higher than in nonthermal areas. The upsurge of air mercury levels during flashing was originally thought to have been a "burst" releasing accumulated mercury at depth. During the July 1977 testing, it was not known that a new East Rift Zone emission center, the Heiheiahulu spatter cone about eight miles to the east of the well, had been active for some months. When that was made known, the cone was tested and found to be a highly intensive mercury emitter and the probable source of the relatively high level recorded at the flashing of HGP-A. Subsequent measurements, made in July-September 1977, show the presence at the well site not only of air mercury but also of $\mathrm{SO}_{2}$ and $\mathrm{H}_{2} \mathrm{SO}_{4}$, although the well itself had been shut down since May 1977. The presence of these toxic gases can only be ascribed to natural area contamination, not emanating from the well itself.

Tests conducted since drilling of HGP-A began have yielded no evidence of a sustained build-up of mercury or any other potentially toxic elements at or around the well site that can be attributed to geothermal energy development operations. The conclusion reached by the researchers is that "there is no reason to assume that $\mathrm{HGP}-\mathrm{A}$ itself has any negative emission features beyond nuisance value $\mathrm{H}_{2} \mathrm{~S}$ and noise, but is (itself) influenced by its proximity to natural geotoxicant sources.

Heavy metals release, including mercury, caused by this project is ex- 
MERCURY LEVELS OUTSIDE THE HGP-PUNA DRILL SITE AREA:

COMPARATIVE AIR AND WATER DATA, 1971-1976

\begin{tabular}{|c|c|}
\hline Sample & $\begin{array}{c}H G \text { Content } \\
\left(\mathrm{ug} / \mathrm{m}^{3} \text { or } \mathrm{ug} / 1\right)\end{array}$ \\
\hline \multicolumn{2}{|l|}{ Air } \\
\hline Thermal & $0.7-40.7$ \\
\hline Hawai i & $1.3-37.0$ \\
\hline $\begin{array}{l}\text { U.S.S.R. } \\
\text { Kamchatka-Kuriles }\end{array}$ & $0.3-18$ \\
\hline \multicolumn{2}{|l|}{ Non-thermal } \\
\hline Hawai i & $0.04-0.3$ \\
\hline Iceland & $0.62-1.0$ \\
\hline New York & $\leq 0.014$ \\
\hline Cincinnati & $0.03-0.21$ \\
\hline $\begin{array}{l}\text { Eastern Pacific } \\
\text { (Open sea-west of California) }\end{array}$ & $\leq 0.0007$ \\
\hline \multicolumn{2}{|l|}{ Water } \\
\hline Poipu Beach (Kauai) & 2.1 \\
\hline Kuhio Beach (Oahu) & 2.3 \\
\hline Nuuanu Stream & 0.6 \\
\hline Oahu aquifer & $<0.2$ \\
\hline $\begin{array}{l}\text { Rain, Hawaij, January } 1972 \\
\text { Is land of Hawaii, general }\end{array}$ & $0.20-0.25$ \\
\hline HVNP fumarole condensate, 1972 & $20-40$ \\
\hline Western Atlantic general & $0.01-0.30$ \\
\hline Hawaii aquifer (Puna) & $\leq 0.5$ \\
\hline
\end{tabular}


pected to be substantially less than the HGP-A reported data. This optimism is predicated primarily on the separate and distinctly different type of release mechanism involved. At HGP-A, the two phase flow under pressure, is suddenly decompressed after passing through the discharge orifice, causing extremely violent expansion and mixing of the brine and vapor fractions. There is substantial entrainment of brine and solids in the vented steam. In the Puna Sugar project, separation of the brine from the steam fraction in the separator is purely mechanical, and agitation is greatly reduced. Entrainment is specifically designed to levels less than $0.01 \%$.

The acceptable level of $\mathrm{H}_{2} \mathrm{~S}$ is subjective and various standards have been adopted based on as many criteria. Table 10-3 indicates some of these standards. With the exception of the OSHA regulations, which are based on possible health hazard levels, there are no applicable $\mathrm{H}_{2} \mathrm{~S}$ regulations in Hawaii.

Under normal production conditions all $\mathrm{H}_{2} \mathrm{~S}$ will be treated and converted to $\mathrm{SO}_{2}$ for eventual recovery. $\mathrm{No}_{2} \mathrm{~S}$ will be released into the atmosphere. On well startup and shutdowns, the steam is bypassed through a silencer and vented into the atmosphere. Caustic and hydrogen peroxide is injected directly into piping at rates exceeding stoichiometric quantities to reduce $\mathrm{H}_{2} \mathrm{~S}$ emission to acceptable levels.

Sulfur dioxide produced by the oxidation of $\mathrm{H}_{2} \mathrm{~S}$ is liauified and recovered for use at the Puna Sugar Company factory. Residuals remaining in the waste gas stream are scrubbed out to levels meeting the State ambient air quality standards (Table 10-3) as measured at the property line, 1700 feet from the source. 
TABLE $10-3$

STANDARDS FOR $\mathrm{H}_{2} \mathrm{~S}$ AND $\mathrm{SO}_{2}$

\begin{tabular}{|c|c|c|c|c|}
\hline \multirow{2}{*}{$\begin{array}{l}\text { STANDARD } \\
\text { Hawaii OSHA } \\
(8 \text { Hour Exposure })\end{array}$} & \multicolumn{2}{|c|}{$(\mathrm{ppm}) \stackrel{\mathrm{H}_{2} \mathrm{~S}}{\left(\mathrm{ug} / \mathrm{M}^{3}\right)}$} & \multicolumn{2}{|c|}{$(\mathrm{ppm}){ }^{\mathrm{SO}_{2}}\left(\mathrm{ug} / \mathrm{m}^{3}\right)$} \\
\hline & 10 & 15,000 & 5 & 13,000 \\
\hline $\begin{array}{l}\text { Hawaii OSHA } \\
\text { (5 Minute Exposure) }\end{array}$ & 20 & - & 20 & - \\
\hline $\begin{array}{l}\text { Alert Level } \\
\text { (24 Hour Average) }\end{array}$ & - & - & 0.3 & - \\
\hline $\begin{array}{l}\text { Identification } \\
\text { ( } 50 \% \text { of Population) }\end{array}$ & 0.030 & - & - & - \\
\hline $\begin{array}{l}\text { Identification } \\
(0 \% \text { of Poputation) }\end{array}$ & 0.010 & - & - & - \\
\hline \multicolumn{5}{|l|}{ Ambient Air Quality } \\
\hline 3 hour & - & - & - & 400 \\
\hline 24 hour & - & - & - & 80 \\
\hline Annual & - & - & - & 20 \\
\hline
\end{tabular}




\subsubsection{Flora and Fauna}

Vegetation in the Puna district is typical of those plants found on the windward side of the Hawaiian Islands. Extensive fields of grass, orchids and fern occupy the plains of the eastern section of the area. With elevation, change is reflected in the increased occurrence of forest trees, especially ohia lehua.

Many of the plants of the grassy plain concerned in this study are exotic rather than endemic. Vegetation within the area consists of agricultural crops (primarily sugar cane), various tropical shrub land vegetation and ornamentals. Certain lands near the project area have been designated as forest reserves, including the Keauohana, Puna, Malama $\mathrm{Ki}$ and Nanawale State Forest Reserves. Only the Puna Forest Reserve is relatively extensive but there are no choice timber areas. Table 10-4 identifies the predominant flora that have been located in the area by previous studies.

No serious environmental impact on the flora of the area will result from the project. Very little of the wellsite area and pipeline corridor remains pristine. Much of the area has been claimed by exotics, principally sugar cane. Agriculture and residential subdivisions comprise the dominant use of the area.

Prior to the settlement of Hawaii by the seafaring Polynesians, the only land mammal living on the island was the hoary bat, which is listed as an endangered species by the U. S. Department of Interior. The region in Puna associated with this project is limited in natural foods and is not rich in fauna. Exotic mammals subsequently introduced consist primarily of rats, pigs, and the mongoose. 


\begin{tabular}{|c|c|}
\hline Common Name. & Scientific Name \\
\hline Koa Haole & Leucaena latisiliqua \\
\hline Lantana & Lantana camara \\
\hline Guava & Psidium guajava \\
\hline Strawberry Guava & Psidium cattleianum \\
\hline Ironwood & Casuarina spp. \\
\hline Christmas Berry Tree & Schinus terebinthifolius \\
\hline Jamaica Vervain (0i) & Stachytarpheta spp. \\
\hline Wiliwili & Erythrina spp. \\
\hline Morning Glory & Ipomoeà sp. \\
\hline Philippine or Wild Orchid & Spathoglottis plicata \\
\hline Passion Fruit (Lilikoi) & Passiflora spp. \\
\hline Glory-Bush & Tibouchina semidecandra \\
\hline Ti Plant & Cordyline terminalis \\
\hline Ohia Lehua & Metrosideros collina \\
\hline Hawaiian Tree Fern & Cibotium spp. \\
\hline False Staghorn Fern & Gleicheniaceae Dicranopteris sp. \\
\hline Smal1 Tree Fern & Sadleria cyatheoides \\
\hline White Ginger & Hedychium coronarium \\
\hline Yellow Ginger & Hedychium flavescens \\
\hline Monkey Pod & Samanea s. saman \\
\hline Mango & Mangifera indica \\
\hline Ieie & Freycinetia arborea \\
\hline
\end{tabular}


TABLE $10-4$ (contd)

PREDOMINANT FLORA FOUND IN THE PROJECT AREA

\begin{tabular}{|ll|}
\hline Common Name & Scientific Name \\
\hline Papaya & Carica papaya \\
Sugar Cane & Saccharum officinarum \\
Kukui & Aleurites moluccana \\
Banana & Musa paradisiaca \\
Sensitive Plant & Mimosa pudica \\
Bamboo & Bambusa vulgaris \\
\hline
\end{tabular}


Several species of indigenous and endangered birds exist on the island. Most of these birds inhabit the dense forests of the uplands, and are rarely observed below 4000 feet elevation. However, three species of endemic land birds are found in the lower elevations. Two of these, the Hawaiian hawk, which is listed as rare and endangered by the U. S. Department of Interior, and the Hawaiian crow, are found only on the island. The third species is the Hawaiian short-eared ow1, which exists on all the major Hawaiian islands. A list of fauna that occur in the plains of the Puna district is covered in Table 10-5.

As with the case of the flora of the area, the environmental impact to the fauna will be insignificant. Pollution discharge levels are minimal with the incorporation of mitigating measures. Destruction of habitat to accommodate the well equipment and steam transmission line will also be minimal for two reasons. The space requirements of the equipment are not large and the area generally does not produce a huge food supply to attract a large population of animals.

\subsubsection{Natural Hazards}

The nature of the island dictates that concern must be given to the effects caused by volcanism and plate tectonics. Volcanic eruptions, earthquakes and tsunamis can cause serious damage and threat to human life and property. The risk associated with them has been addressed in Section 8 .

Severe weather is another source of hazard in the area. Generally speaking, however, the area is free of major storms. Hurricanes rarely pass over the island, with only four affecting the area in the last 63 years. Strong winds that are generated by tropical storms occur most often from July to December. Wind damage is not a major concern as the facilities 
Common Name

Mongoose

House Mouse

Norway Rat

Roof Rat

Polynesian Rat

Pig

Hoary Bat

Hawai ian Hawk

Hawaitan Crow

Hawaitan Owl (Puueo)

Japanese White-eye

Barred Dove

Spotted Dove

Common Myna

Spotten Munia (Ricebird)

Melodious Laughing Thrush

Cardinal

House Finch

House Sparrow

Golden Plover

Mockingbird
Scientific Name

Herpestes a. auropunctatus

Mus musculus

Rattus novegicus

Rattus rattus

Rattus exulans

Sus scrofa

Lasiurus cinereus semotus

Buteo solitarius

Corvus tropicus

Asio flammeus sandwichensis

Zosterops j. japonica

Geopelia s. striata

Streptopelia c. chinensis

Acridotheres t. tristis

Lonchura punctulata

Garrulax canorus

Cardinalis cardinalis

Carpodacus mexicanus frontalis

Passer domesticus

Pluvialis dominica fulva

Mimus polyglottos 
will be uniformly designed to withstand 100 miles per hour wind velocities.

The primary concern from natural hazards is steam pipeline breaks caused by surface ruptures or lava inundation. The probability of such occurrences is slight and impact to the environs is expected to be minimal and transitory. Pipeline flows can be immediately shut down following a loss of line pressure.

\subsubsection{Aesthetics}

The County of Hawaii General Plan adequately describes the concerns of the island populace with regard to the importance of aesthetics in island Tife.

The natural beauty of Hawai i is a universally recognized fact and as such is one of our most significant assets. In a relatively small area exists a great range of environments, from lush green tropical valleys to snow-capped mountains. This diversity enhances the liveability of the island by providing a choice of physical conditions.

Hawaij's natural beauty is the manifestation of the interplay of various physical elements and forces. Three primary factors contribute to the variety of environments: elevation and relative location, geologic origin and age. A further factor is modification by man. The types of landform and vegetation depend on these basic factors. Due to various conditions, such as different elevations and sides of the island, the landscape has particular characteristics. These include barren fields of lava, heavily vegetated valleys, kiawe deserts, native forests, rolling grasslands, and rocky coastlines. The differences in 
the environment and landscape are important in giving identity to areas of the island and in supporting man-made elements.

As a resource, natural beauty has many aspects. It is an aesthetic resource, experienced by human senses. Natural beauty has economic ramifications, as evidenced by the scale of resort development. Another aspect is that the physical elements which make up the landscape and the interrelationships of these elements are of scientific interest. Investigating and understanding the physical environment are necessary in order for man to live in balance with it and not destroy it.

As the population increases, the desire to experience natural beauty will continue and may increase. If uncontrolled, the development necessary to accommodate an increasing population as well as resort development could have detrimental effects on the natural beauty of the island. Areas with special amenities of natural beauty have been and will continue to be the focus of pressure for resort development. Present regulations to protect extraordinary vistas and sites of natural beauty are inadequate. The cost of restoring or regaining natural beauty is greater than the cost of protecting it.

This gift of nature is an irreplaceable asset of public trust. It is fragile and although often enhanced by man, it can easily be destroyed by him. Measures must be taken to insure its protection, both now and in the future, for the enjoyment of residents and visitors. 
Visual. The project will have visual effect on the area. The well site, process equipment and the exposed portions of the pipeline will be incongruous with their background. The impact will be mitigated primarily by the remoteness of the facility. The well site and the major portion of the transmission pipe will not be visible from any public roads, being screened by topography and vegetation. The pipeline section traversing the residential subdivisions between the East Rift Zone and Keaau will not be visible, although the grade level concrete pipe trench cover can be seen along the road shoulders.

Odor. Geothermal fields have a distinctive odor associated primarily with hydrogen sulfide $\left(\mathrm{H}_{2} \mathrm{~S}\right)$, and this project is no exception. While odors in this relatively remote area may be tolerable for short durations, any permanent facility must address and mitigate the problem to acceptable levels. Hydrogen sulfide abatement is further discussed in the subsection concerning chemical toxicants and Section 6 .

Noise. Individuals react differently to sound levels and many attempts have been made to find a simple measure of sound that correlates well with the human response to typical noise environments. Measurement of different noises does not always correspond to the relative loudness or annoyance due to the complexity of the human ear and difference in perception.

Several scales of measurement have been developed to evaluate different noise sources. The most commonly used scale is called the decibel (dBA). The decibel is a unit which weighs the sound pressure of various frequencies which make up noise.

Since the weighing cannot reflect the response of different people, sta- 
tistical human auditory data is used to construct the weighing factors $\left(L_{A}\right)$ which take into account such characteristics of the human ear as its sensitivity to high frequencies above 1,000 hertz. It is important to understand that the dBA scale is a logarithmic rather than a linear measure of sound intensity; consequently a $10 \mathrm{dBA}$ increase denotes a factor of 10 higher in intensity, while a $20 \mathrm{dBA}$ increase denotes a factor of 100 . In terms of perceptible annoyance to people, a $10 \mathrm{dBA}$ increase in sound levels doubles the apparent loudness of the sound. Conversely, a $10 \mathrm{dBA}$ decrease in sound level will halve the apparent loudness, as heard by the human ear. Table 10-6 lists typical sound levels associated with some familiar noise sources.

The $A B A$ was used as the noise descriptor for this assessment because it not only correlates well with human perception and response to industrial noise sources, but is also used by many Federal and State agencies for standards and ordinances.

Presently, there are no noise regulations for the County of Hawaii. The U. S. Environmental Protection Agency, the State of Hawaii Department of Health, and the County are interested in enactment of noise control regulations. In addition, the City and County of Honolulu has adopted noise regulations specifying allowable noise levels at the property line.

The County of Hawaii has prepared an allowable noise level regulation for residential, commercial, and industrial areas. However, this bill was not passed and is currently tabled. Table 10-7 shows these proposed allowable continuous noise levels.

The first step in determining the existing noise climate in the vicinity 
TABLE $10-6$

TYPICAL SOUND LEVELS

\begin{tabular}{|lc|}
\hline \multicolumn{1}{|c|}{ Noise Source } & $\begin{array}{c}\text { Measured Noise Level } \\
\text { (dBA) }\end{array}$ \\
\hline Jet Taking Off & 120 \\
HGP-A Geothermal Well (Unmuffled) & 120 \\
Thunder or Sonic Boom & 112 \\
Power Lawn Mower & 93 \\
Project Geothermal Wel1 (Muffled) & 90 \\
Train at 50 Feet & 88 \\
Heavy Street Traffic & 84 \\
Garbage Disposal in Sink & 80 \\
Factory & 72 \\
Typing Pool of 9 Persons & 65 \\
Typical Business Office & 55 \\
Quiet Street & 43 \\
Project Site Area & 43 \\
Library & 35 \\
& \\
\hline
\end{tabular}

SOURCE: U. S. Environmental Protection Agency, Hawaii Geothermal Project and W. A. Hirai \& Associates, Inc. 


\section{TABLE $10-7$}

PROPOSED COUNTY OF HAWAII

ALLOWABLE NOISE LEVELS

\begin{tabular}{|lcc|}
\hline District & Time of Day & $\begin{array}{c}\text { Allowable } \\
\text { Noise Level* } \\
\text { (dBA) }\end{array}$ \\
\hline Residential & $7 \mathrm{am}-10 \mathrm{pm}$ & 55 \\
Commercial & $10 \mathrm{pm}-7 \mathrm{am}$ & 50 \\
& $7 \mathrm{am}-10 \mathrm{pm}$ & 60 \\
Industrial & $10 \mathrm{pm}-7 \mathrm{am}$ & 55 \\
& $7 \mathrm{am}-10 \mathrm{pm}$ & 80 \\
& $10 \mathrm{pm}-7 \mathrm{am}$ & 75 \\
\hline
\end{tabular}

*Measured at a distance of 25 feet from the noise source. 
of each station site was to take a series of noise measurements. These measurements were made by W. A. Hirai and Associates in December, 1978 in the vicinity of the proposed well site. The existing noise levels measured an average of $43 \mathrm{dBA}$ and is shown in Table 10-6.

To predict the noise level near the well site, several worst case assumptions were made. First the noise level generated at the well site was assumed to be $90 \mathrm{dBA}$, the maximum permissible 8 hour noise exposure OSHA standards permit without ear protection. Secondly, no sound attenuating enclosure was assumed to surround the site and no walls were assumed to be placed around the noise emitter. Thirdly, no reduction in noise level was assumed because of other machinery, buildings, or landscaping that might deflect, absorb, or dampen noise. Given the "worst case" assumptions above, Table 10-8 relates these predicted noise levels at various distances from the noise source.

In actuality, the elevated noise levels will probably be 10 to 15 per cent lower than predicted as the site is buffered by tree growth and other machinery, and walls will deflect and absorb sound. Regardless of these benefits, noise attentuation will be sufficient such that noise levels will be acceptable at the closest property boundary, and probably indistinguishable at the nearest residence.

Noise emitting from the transmission pipe will not be a concern. The passage of steam through the pipeline will not be heard since pipeline velocities are relatively low and the pipe will be covered with thermal insulation five inches thick.

\subsection{THE SOCIO ECONOMIC ENVIRONMENT}

The Puna district is a sparsely populated rural area, with much of the 
TABLE $10-8$

PREDICTED NOISE LEVELS NEAR THE WELL SITE

\begin{tabular}{|ccc|}
\hline $\begin{array}{l}\text { Distance From } \\
\text { Wellsite }\end{array}$ & $\begin{array}{c}\text { Background } \\
\text { Noise Level } \\
(\mathrm{dBA})\end{array}$ & $\begin{array}{c}\text { Predicted Noise } \\
\text { Leve) } \\
(\mathrm{dBA})\end{array}$ \\
\hline 1 & 43 & 90 \\
$25^{1}$ & 43 & 62 \\
100 & 43 & 51 \\
500 & 43 & 44 \\
$1700^{2}$ & 43 & 43 \\
$2750^{3}$ & 43 & 43 \\
\hline
\end{tabular}

1. Proposed County standard of $80 \mathrm{dBA}$ for industrial areas measured at 25 feet during daytime hours, 75 dBA during nighttime hours.

2. Distance to Puna Sugar Co. property boundary.

3. Distance to the nearest residence 
population meeting the needs of the agrarian economy. However, with recent improvements in transportation facilities, the district is becoming one of the larger residential areas for the working population of the City of Hilo.

\subsubsection{Land Ownership}

Land ownership on the island is highly concentrated, with 40 separate owners owning approximately $92.8 \%$ of the land. Of this total, the State of Hawaii is the largest landowner, with holdings of $43.8 \%$.

In the Puna district, land ownership can be summarized as follows:

$\begin{array}{lc}\text { Owner } & \text { Land Area (Acres) } \\ \text { State of Hawaii } & 77,800 \\ \text { Federal } & 61,550 \\ \text { Private } & \\ \quad \text { Puna Sugar Company } & 17,336 \\ \text { Others } & \underline{160,314} \\ \text { TOTAL } & 317,000\end{array}$

These areas are shown on the land ownership map, Figure 10-3. No lands are expected to be exchanged, although pipeline corridor easements must be purchased for the transmission of the steam resource from the wells to the factory site.

\subsubsection{Land Use}

Hawai $i$ was the forerunner of the fifty states to have a state-wide General Plan and State Land Use Law. The latter established the State Land Use Commission, and called for the classification of all lands in the State. Accordingly, four separate land use districts were created: Urban, Rural, 


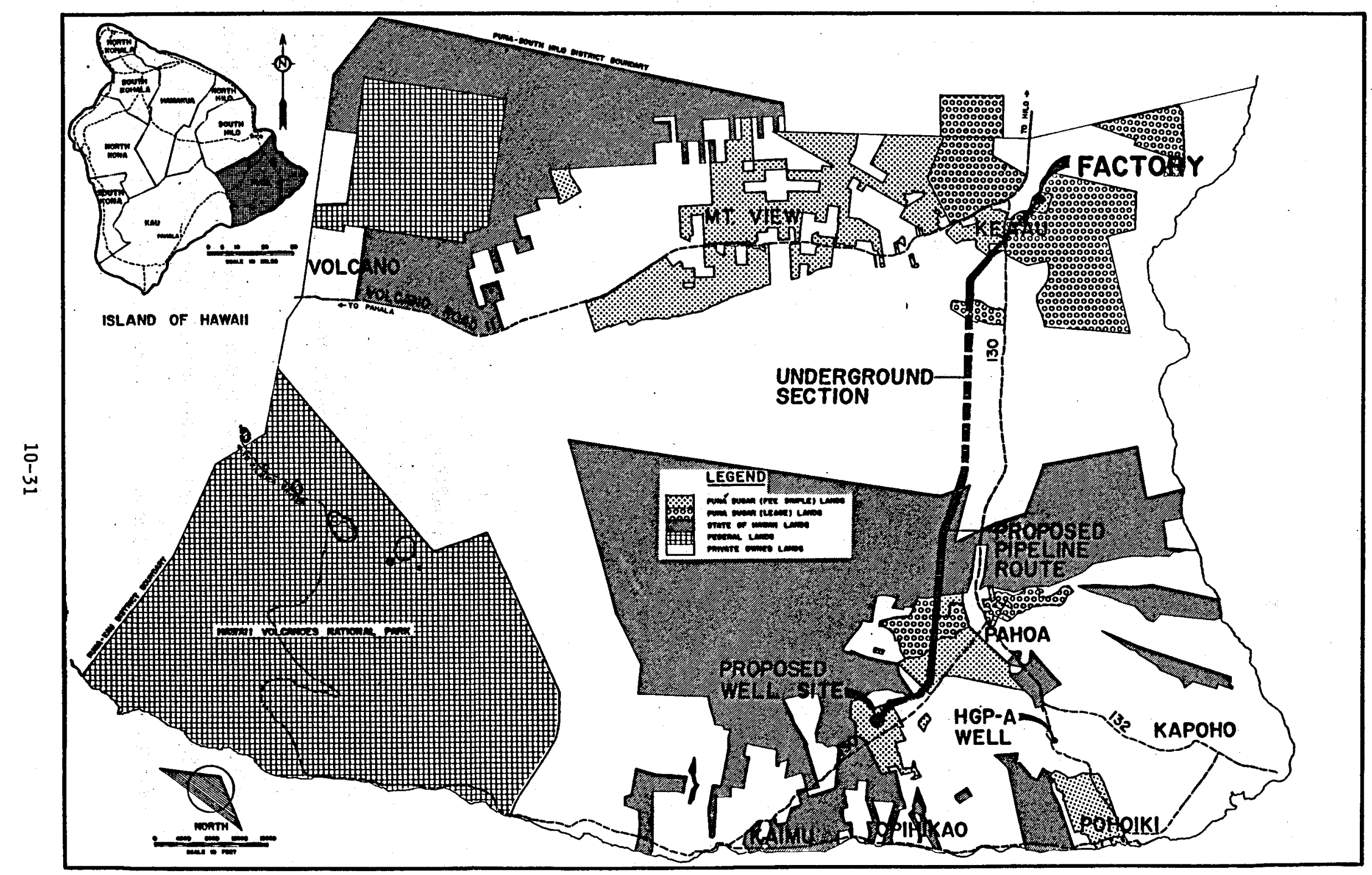

FIGURE $10-3$

MAP OF LAND OWNERSHIP, PUNA DISTRICT 
Agricultural, and Conservation. Land uses within the urban districts are administered exclusively by the counties in which they are located. In Agricultural and Rural districts, regulations established by the Land Use Commission are administered by the respective counties; and in conservation districts, all activities are administered by the State Department of Land and Natural Resources.

The County of Hawaij's General Plan was developed to express the integrated and specific concerns and problems, and alternative solution and guidance regarding the use of County resources. In the land use aspect, lands were allocated for the following uses:

- Medium Density

- Low Density

- Industrial

- Intensive Agricultural

- Extensive Agricultural

- Orchards

- Resort

- Open Area

- Conservation

- Alternate Urban Expansion

These land use allocations are shown for the Puna district in Figure 10-4. The entire project area is within the State agriculture land use designation. A11 uses are compatible and permitted within the land use district except for the wells and well site facilities. A special permit must be secured for the well site. Permits are granted for certain unusual and reasonable uses. It is felt that the well site facilities are reasonable 
C

C

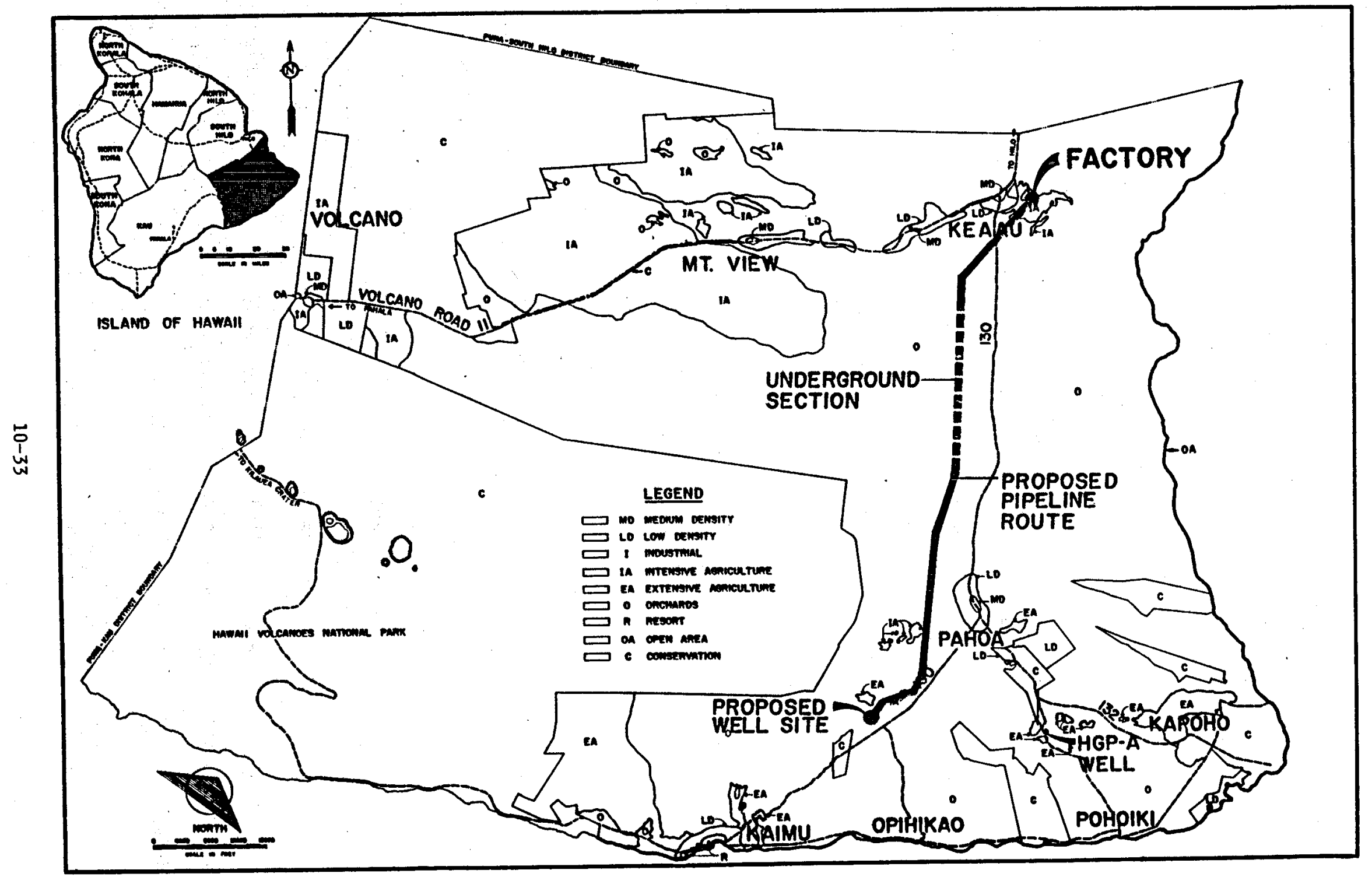

FIGURE $10-4$
USE ALLOCATION, DUNA DISTRICT 
uses of the land. It will not adversely affect the land or the surrounding property, will not adversely burden the infrastructure, and the land itself is basically unsuited for the uses permitted in the district. The process of permitting is more fully described in Section 11 .

\subsubsection{Land Zoning}

The zoning code for the County of Hawaii provides the legal means by which the County regulates the use of the land. This code implements the General Plan, and deals with existing conditions and the short range needs of the County.

The zoning categories for the Puna district include the following:

- Single Family Residential

- Residential Agriculture

- Agriculture

- Open

- Forest Reserve

The present zoning provides approximately 190,000 acres for agricultural use. Within the district about 52,000 acres are actually utilized for agriculture.

Figure $10-5$ is a zone map of the Puna district which indicates the distribution and acreages of the various zones. The project will encroach on agricultural lands zoned for one, five, and twenty acre parcels. Pipelines are within the permitted uses in these areas. However, the well and well site facility need a special permit to function.

\subsubsection{Sugar Production Areas}

The Puna Sugar Company uses approximately 30,593 acres of land for the 


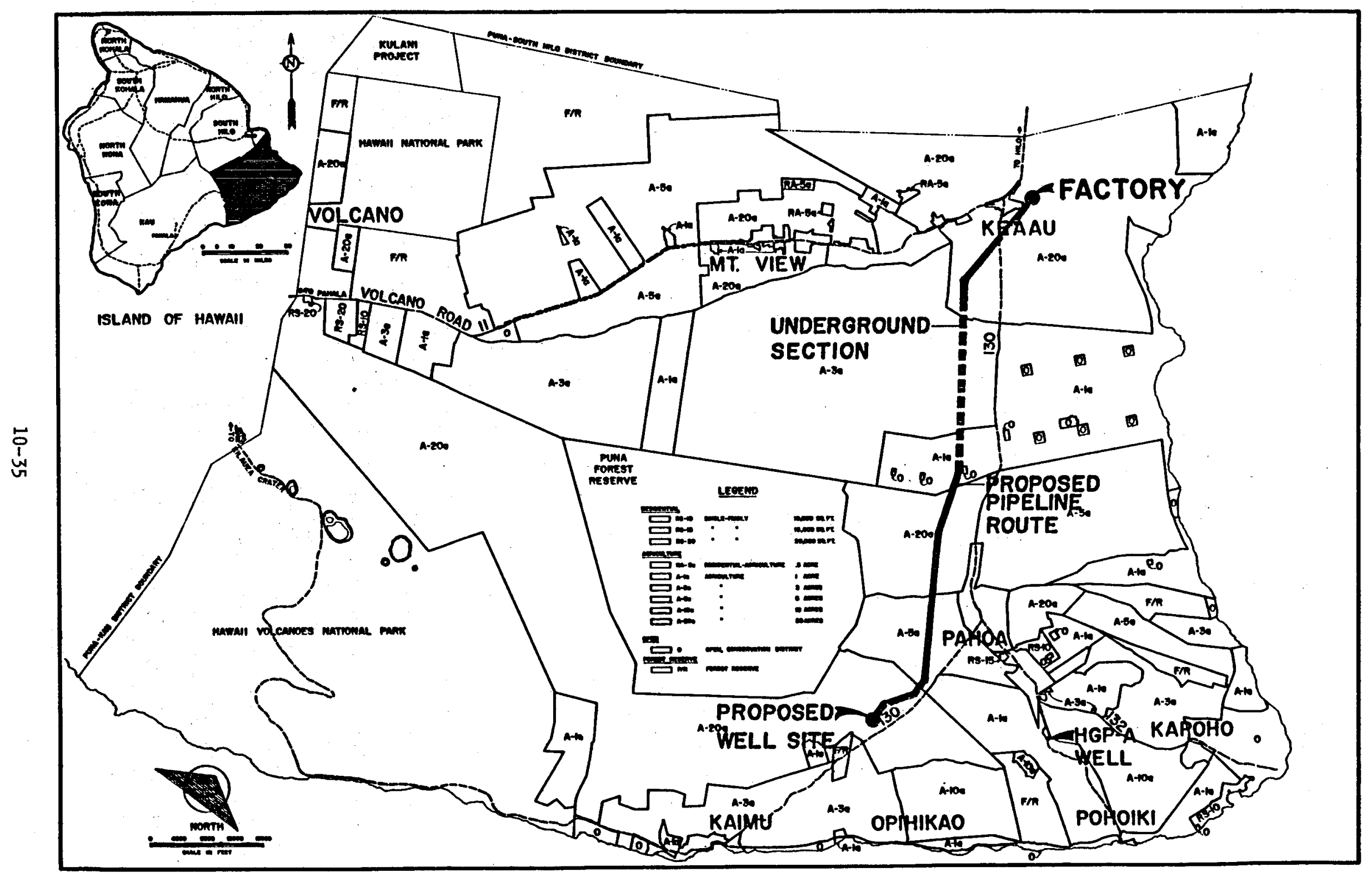

FIGURE $10-5$

MAP OF LAND ZONING, PUNA DISTRICT 
entire operation. This acreage includes land owned in fee, and also leased lands. Of this total, only 15,858 acres are actually used for growing the sugar cane crop. The remainder is accounted for as contributory, diversified crop, forest, pasture, or waste lands. The sugar cane crops are grown in the Keaau-Mountain View area, and also in land surrounding Pahoa.

of the crop presently being grown, the majority is considered productive. Certain other uses, such as crop grown for seed cane, are considered nonproductive. Both the productive and non-productive areas are depicted on the map shown in Figure 10-6.

No sugar cane is grown in the well site area. The impact of the pipeline crossing the cane fields from the East Rift Zone will be minimal. Some acreage will be displaced but will amount to less than 20 acres. No toxic conditions will be inflicted on the cane due to the proposed system.

\subsubsection{Infrastructure and Economic Circumstances}

The project will not have a material effect on the infrastructure of the district. It is basically a self perpetuating system with few exceptions. Minor quantities of electricity will be needed to supply water to the well site. The need for initial and replacement equipment parts will add to the burden of the supply system, but the increased level of activity is well within the current capacity of the system.

With $\$ 21,000,000$ being expended for construction, there will be an increase in construction activity. However, the bulk of the construction costs are related to capital goods such as pipe and process vessels.

Hence the number of jobs that will be available at any point during the 


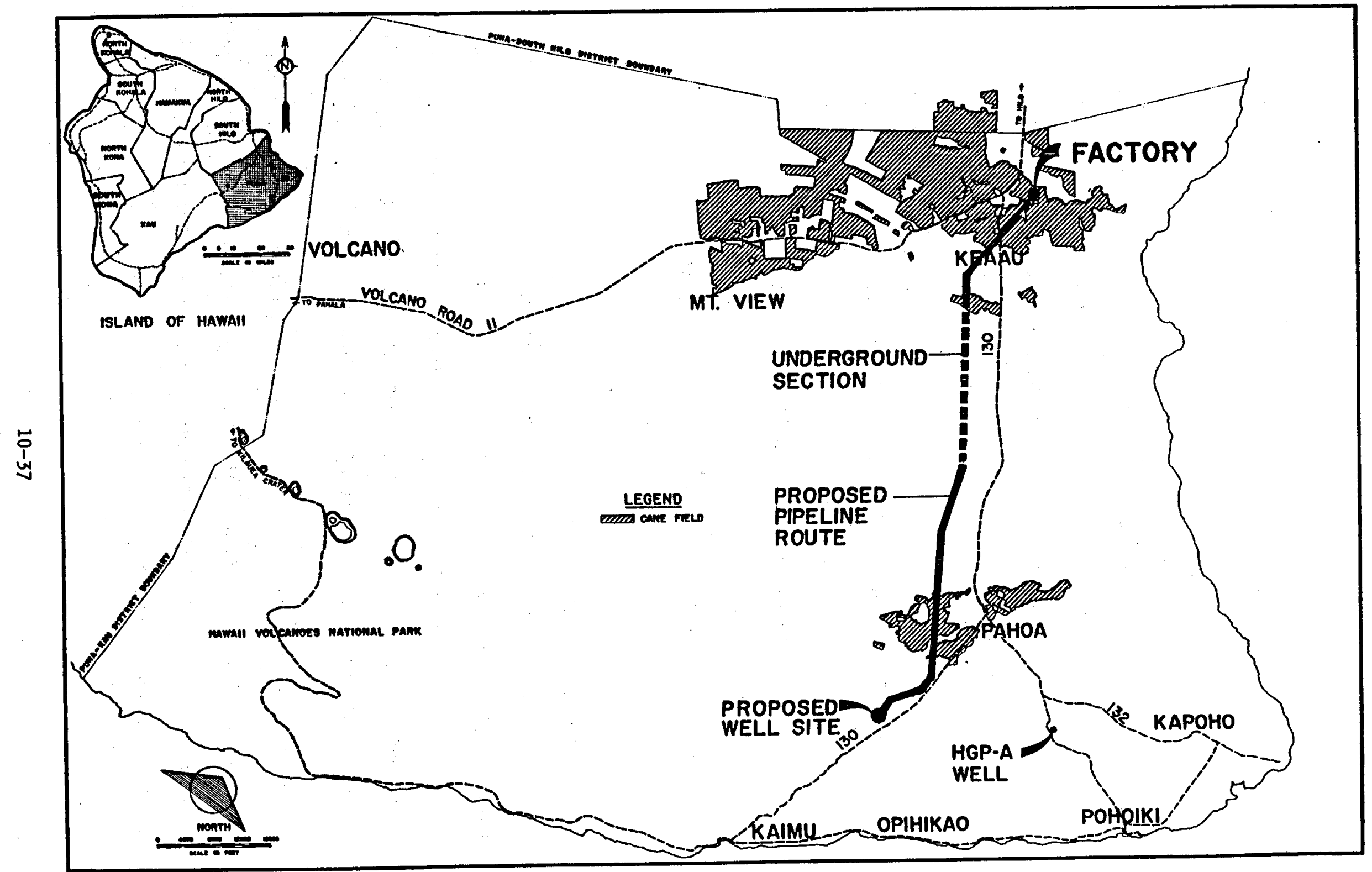

FIGURE $10-6$

MAP OF PUNA SUGAR COMPANY CANE LANDS 
two year construction phase is estimated to number less than 150 . The requirement will probably be easily accommodated by the State's construction industry.

The project will require a permanent staff of 9.5 persons. Even utilizing the average employment multiplier of 3.29 , less than 32 new statewide jobs will be created by the project. Thus there will be no significant impact on the State labor market.

The major area of public impact will be economic. Electrical power sales utilizing the Puna Sugar turbogenerator will cause more lower cost electricity to enter the utility grid, resulting in a net savings to the community. In addition, the State will be the beneficiary of geothermal royalty payments and taxes from 0 \& $M$ expenditures. Total accumulated public benefits from this project will be at least $\$ 79,000,000$ during the 20 year life of the system.

\subsubsection{Archaeological and Historic Sites}

A review of the immediate environs of the project area reveals no designated areas by the Hawaii Register of Historic Places nor are there any known archaeological sites in the area. Much of the East Rift Zone area has been inundated by lava flows since inhabitation and indications are that the district was never a center of early Hawaiian political activity.

The primary concern remains in the pipeline corridor from the East Rift Zone to the factory at Keaau. Although very little of this area is pristine, at least a cursory archaeological survey appears warranted for private lands of the pipeline corridor. 


\subsubsection{Hawaiian Culture}

Discovery of the Hawaiian. Islands by Westerners in the eighteenth century revealed a native socio-economic society that was a well structured operating entity. The populace was divided into four distinct classes, with the island ruled by kings $\left(a i^{\prime} i\right)$ and chiefs. Priests and master craftsmen were collectively known as kahunas. The maka'ainana, or commoners, comprised the bulk of society, and with them rested the burden of providing for the economy. At the lowest rung of the the societal hiearchy were the kauwa or outcasts. These unfortunates were landless, had no rights in the community, were confined to designated restricted areas, and supplied victims from their ranks for human sacrifices.

Society was governed by a body of religious law known as kapu (sacred or forbidden). It was one of the two main concepts of the Hawaitan philosophy of life. The other was mana or supernatural power. Deities could impart mana to objects and people, especially chiefs of high rank. The conflict of mana and kapu permeated to all levels of the society, and the kahunas assumed important roles.

Among the deities is the volcano goddess, Pele, believed to reside in the bowels of Halemaumau, a pit crater within the Kilauea caldera. While her doma in blankets all the islands of Hawaii, she is especially active in the Kilauea caldera and rift zone areas. All volcanic activity is associated with her.

The Hawaiian econqmy was subsistent on the natural resources of the land and sea. Taro, sweet potatoes, and yams were cultivated and other wild food collected from the forests, while fishermen harvested the ocean. These goods were continuously exchanged on an informal basis between 
members of the ohana or kin group. Kinship in this case related to a communal society, and was not strictly limited to blood relationship. Trade between localities existed only where there was a considerable surplus of goods. But these were the exceptions, and in general, society operated in an atmosphere of sharing and cooperation.

As a consequence of the negative societal attitude toward commercialism, there were no large towns or settlements in prehistoric Hawaii. Many small villages existed near the shoreline, within easy access of the sea, water, and lands that were vital to the Hawaiian's existence.

All the land belonged to the king who alloted tracts of land from time to time to the principal chiefs, subject to revocation at will. Upon death of the King, each principal chief derived his lands anew. In turn the chief subdivided his land into tracts called kuleana and ili. Under this system even the lowest class commoner was afforded land. The concept of fee simple land ownership was unknown, but the principal of tenure of commoners' lands was generally adhered to.

Although larger divisions existed, the basic land unit was the ahupuaa. These ideally were economically self-sufficient tracts of land, somewhat wedge shaped, with natural boundaries: reaching from the mountain tops to the ocean. Within its boundaries, and aside from cultivated areas, its residents had the lawful right to grow crops, pasture animals, and to gather such necessities as firewood, house timber, aho cord, thatch and ti leaf for their own use. Today, lawful occupants of the kuleanas still retain these gathering rights.

The rapid influx of Western whites during the latter 18th and early 19th century completely altered the socio-economic pattern of Hawaii. Within 
a short span, a society which had always existed on subsistence became dependant on international trade.

Land tenure patterns reflected and served this move toward a more traditional Western economy. For the first time, the Law of 1825 allowed chiefs to retain their lands following a king's death. Westerners were "given" lands for services rendered, or merely out of traditional Hawaiian generosity. The Constitution of 1840 attempted to adjust the land rights between chiefs and commoners and between Hawaiians and whites. But by 1845 the land tenure system was completely untenable to the Westerners. A commission was created which totally defeudalized land holdings. With the Great Mahele, or division, in 1848, lands were set aside for the king, chiefs, and tenant farmers. By 1850, the right of Westerners to own land was law; the principle of fee simple ownership had come of age.

While the mainstream of the modern Hawaiian economy is now completely Westernized, pockets of a more traditional lifestyle still exist. Such is the conflict in Puna, where the traditional socio-economic pattern is rather pronounced in certain places. What specific effects the well site facilities and pipeline will have on this lifestyle is not known.

At the least, it is not congruous to the background of that existence. Ramps over the pipeline will be located at approximately 600 foot intervals in state ahupuaa lands to provide access for traditional gathering rights. The need for more ameliorative provisions is more properly addressed in an environmental impact statement. 
10-1 The General Plan, County of Hawaii, Planning Department, County of Hawaii, January, 1971.

10-2 Data Book 1976, Department of Research and Development, County of Hawaii, August, 1976.

10-3 The State of Hawaii Data Book, A Statistical Abstract, Department of Planning and Economic Development, State of Hawaii, 1975.

10-4 Inventory of Selected Water, Land and Related Resources Data, U. S. Dept. of Agriculture, June, 1975.

10-5 Zone Map, Puna District, Planning Commission, County of Hawai i, Dec. 20, 1967.

10-6 Kamins, R. , et al., Environmental Baseline Study for Geothermal Development in Puna, Hawai i, HGP Report, Honolulu, Hawaii, Sept. 1976.

10-7 Kamins, R., Revised Environmental Statement for the Hawaii Geothermal Research Station Utilizing the HGP-A Well at Puna, Island of Hawaii, Department of Planning and Economic Development, State of Hawaii, March 1978.

10-8 Hawaii Water Resources Regional Study, Study Element Report, Floods, Honolulu, Hawaii, April 1975.

10-9 Hawai i Water Resources Regional Study, Study Element Report, Environmental Base, Honolulu, Hawaii, April 1975.

10-10 Soil Survey of Island of Hawaii, State of Hawaii, U. S. Department of Agriculture, Soil Conservation Service, Washington, D. C., December 1973.

10-11 Stephen-Hassard, Q. Dick, et al., The Feasibility and Potential Impact of Manganese Nodule Processing in Hawaii, Dept. of Planning and Economic Development, State of Hawaii, Honolulu, February 1978.

10-12 Keaau-Pahoa Road, Pahoa Bypass Project No. RS-130 (17), Environmental Impact Statement, Federal Highway Administration, USDOT and Land Transportation Facilities Division, Hawaij DOT. 
10-13 Final Environmental Statement, Proposed Master Plan, Hawai i Volcanoes National Park, Hawaii, Western Region, National Park Service, Dept. of the Interior, August 1975.

10-14 Macdonald, G. A. and Abbot, A. T., Volcanoes in the Sea, University of Hawaii Press, Hoñolulu, 1970.

10-15 Mullineaux, Donal R., and Petersen, Donald W., Volcanic Hazards on the Island of Hawai $i$, Open file report 74-239, USGS, 1974.

10-16 Levy, Neil M., "Native Hawaiian Rights," California Law Review, 63:4 (July, 1975), 848-885.

10-17 McUamara, Jack, The Legal and Institutional Problems Facing Geothermal Development in Hawaii, Prepared for Pacific Region Team, DGE, USDOE by J. M. Energy Consultants, Inc., 0ct. 1, 1978.

10-18 Starzecka, Dorota Czarkowska, Hawaii People and Culture, Published for the British Museum by British Museum Publications, Ltd., London, 1975.

10-19 Hitch, Thomas K., How the Collapse of the Sugar Industry Would Impact on Hawaij's Economy, Research Division of the First Hawaiian Bank, June 15, 1978.

10-20 Hawaii Water Resources Regional Study, Study Element Report, Surface and Ground Water Resources, Honolulu, Hawaii, Apri1, 1975. 
Section 11

INSTITUTIONAL CONCERNS

The technology associated with this project appears to be either commercially available or readily solvable. A general consensus clearly shows that the development of an indigenous source of alternate energy compatible with the lifestyle of the community is desirable for the island and the state. Ultimately it may be institutional considerations that will be the major constraint in an implementation program. These institutional problems must be resolved for geothermal utilization to proceed.

\subsection{ADMINISTRATIVE REGULATIONS}

The fact that both the County of Hawai $i$ and the State of Hawaii have expended considerable sums of capital to explore and demonstrate the feasibility of geothermal utilization argues well for their commitment to geothermal development. The State General Plan focuses on the development of indigenous energy sources as a major plan objective. Revisions to the County's General Plan, now being finalized, note that the administration is particularly cognizant of the area's near total dependence on imported petroleum, which makes it vulnerable to dislocations in the global oil market. It has concentrated its efforts to establish the island as a demonstration community for the development and use of natural energy. resources and is committed to an energy self-sufficiency program. However, while the directive and commitment are clear, specific steps toward any implementation can be obstructed. 


\subsubsection{Geothermal Ownership Rights}

In 1974, the Hawaii State Legislature produced Act 241 which in part amended Section 182-1, Hawaii Revised Statutes (HRS) to define geothermal resources as a mineral. Locally, there appears to be general agreement of this definition.

What remains is the question of geothermal resource ownership. Three catagories of land exist with respect to geothermal or mineral rights.

- State owned lands, where the State owns the mineral rights.

- State lands granted out by the State where there is a mineral reservation clause. Here it is is quite clear that the present owner or occupant has no inherent vested rights to the geothermal resources.

- Privately owned lands without a mineral reservation clause. Historically, and probably the general rule today in the United States is that the owner has all rights up to the sky and to the center of the earth. In Hawaij however, the State Attorney General's position is that the rule has been modified through the public trust doctrine. The basis for this determination is in part due to decisions rendered by the Hawaii Supreme Court in County of Hawaij v. Sotomura and McBryde Sugar Company v. Robinson. Both case decisions were reversed in Federal District Court recently and the latter is currently pending before the 9th Circuit Court of Appeals in San Francisco.

In any case, the ownership of mineral rights is a cloudy issue. Arguments can support both private and state ownership. While indications are that the State Legislature will adopt statutory sections dealing with ownership, the question will not be resolved within a short time. Ultimately, it will 
have to be treated in the courts. What impact this and the associated burgeoning native Hawaiian rights issue will have on the orderly development and early commercialization of geothermal energy in Hawaii remains unanswered.

The particular application of the project being evaluated in this study skirts the basic issue of owner/State resource ownership. All real estate within the immediate area of the well site contains mineral reservation clauses reserving the geothermal heat to the State. Royalties will be paid, but who the ultimate recipient parties will be has not been indisputably determined.

\subsubsection{Permitting Process}

The permitting and approval activities for geothermal projects function at both the County and State levels of government. At times these areas of responsibility overlap and confusion can occur. To improve the coordination and efficiency of the land use and planning control systems, the Planning Department of the County of Hawaij has been designated as a central coordinating agency. Among its duties in this capacity, it maintains and continuously updates a repository of all laws, rules and regulations, procedures and permit requirements. It also reviews criteria of all Federal, State, and County agencies having control or regulatory powers over land development projects within the county. This repository is available for use by prospective developers.

Geothermal Exploration Permit. An exploration permit is required by the State Board of Land and Natural Resources to conduct any exploration activity which relates to the search on State or reserved lands for evidence of geothermal resources. Such exploration activity includes, but is not limited to, geophysical operations, drilling of shallow temperature test holes less than 500 feet in depth, or deeper as may be 
determined by the Board, construction of roads and trails, and crosscountry transit by vehicle over State lands.

Geothermal Mining Lease. The State Board of Land and Natural Resources may, in accordance with regulations, grant mining leases conveying to the lessee the exclusive rights to drill, discover, develop, operate, utilize, and sell geothermal resources on state and reserved lands. The leases are, however, subject to the Board's right to issue exploration permits on the leased land for the sole purpose of evaluating the extent of geothermal resources existing on adjacent State or reserved land. The Board sets forth the terms and conditions of such a mining lease prior to the public auctioning or granting without public auction. A mining lease for the proposed wellsite in this project would probably be granted without a public auction. This opinion is based on the surface being owned in fee by Puna Sugar Company and prior administrative precedence.

Geothermal Drilling Permit. All wells drilled in the State of Hawaii for the exploration, discovery, evaluation, development, production, utilization or injection of geothermal resources and by-products shal1 be subject to the regulations of the State Department of Land and Natural Resources, which are statewide in application. They shall be drilled, operated, and maintained or abandoned in such a manner as to prevent waste, to conserve and provide for optimum use of geothermal resources, to prevent degradation of the environment, surface and ground and other natural resources, and to prevent injury to life and property. Prior to drilling, the operator must file with the Board of Land and Natural Resources for a permit to perform the work.

Environmental Impact Statement Review. An environmental impact statement 
(EIS) may be required of the steam transmission pipeline traversing State lands between the East Rift Zone and the Puna Sugar factory. An EIS is required only when agencies determine that the project may have a significant effect on the environment. If impacts are judged to be insignificant, a negative declaration is filed with the Environmental Quality Commission (EQC) by the agency making such a determination.

The Environmental Quality Commission was directed by law to devise rules and regulations to guide EIS preparation. These rules lay out a general EIS format through which the applicant must respond to a number of specific topic areas in sufficient detail to permit decision-makers to fully anticipate the environmental consequences of the proposed action. The major categories of information called for in the regulations are as follows:

- Summary sheet which outlines and concisely discusses the contents.

- Project description.

- Description of the environmental setting.

- The relationship of the proposed action to land use plans, policies, and controls for the affected area.

- Any probable adverse environmental effects which cannot be avoided.

- Alternatives to the proposed action.

- The relationship between local short-term uses of man's environment and the maintenance and enhancement of long-term productivity.

- Mitigation measures proposed to minimize impact.

- Any irreversible and irretrievable commitments of resources.

- An indication of what other interests and considerations of governmental policies are thought to offset the adverse environmental effects of the proposed action. 
- Organizations and persons consulted.

If it is determined that an EIS is required, a notice is published in the EQC Bulletin advising the public that an EIS will be prepared. The Environmental Impact Statement Preparation Notice (EISPN) prepared by the agency requiring the EIS, summarizes the proposed action, points out areas of potential impact, and generally documents the steps and criteria used in making the decision.

Following the publication of the Notice, the public can request to be a consulted party during EIS preparation. After the EIS is prepared and circulated, the public again can comment in writing. The applicant must respond in writing to any such public inquiries.

An EIS is accepted or not accepted by the agency requiring it. Agency acceptance of an EIS means that all identifiable environmental impacts have been adequately described, and questions raised during the review phase of the document have been satisfactorily answered by the applicant.

Special Permit (Agriculture and Rural Districts). The well drilling for geothermal resources and wellsite facilities are not within the specific designation of permitted land uses for the property. The developer must petition the County Planning Commission for a special permit to use the land in the manner desired.

The request is reviewed by the County Planning Department and a recommendation forwarded to the Commission at the time of a public hearing. Should the request be approved, the Commission forwards the request, the findings, and the entire record of hearings to the State Land Use Commission. 
The State Commission must act to approve, approve with modification, or deny the permit. It may also impose additional restrictions, but may not delete any conditions set by the Planning Commission in issuing the permit, nor make these conditions less restrictive.

Plan Approval. No structure may be erected or no use may be established in RS, CO, CV, RM, V, CN, CG, ML, MG, U, or 0 districts or within 75 feet of the right-of-way of any road, street or highway designated on the County Zoning Map as a tourist route unless plan approval has first been secured for such structure or use. The plan approval may also be required as a condition of approval for any use permit, variance, or other action relating to the specific use.

Plans must be submitted to the Planning Department for review and comments. The department considers the application together with all accompanying data and either denies, approves, or defers the application subject to conditions or alterations. Consideration is given in review to the proposed use in relation to surrounding property, improvements, streets, traffic, community characteristics and natural features, among other criteria.

Zoning Variance. A zoning variance is required when a developer wishes to deviate from the provisions of the County Zoning Code. In the case of this project, variances are not expected to be required for the agriculturally zoned areas. The zoning variance is not to be confused with the special permit which allows nonconforming use on the property.

The County Planning Commission considers the application during a preliminary hearing. Should there be validity in the use, a public hearing is scheduled. The commission subsequently denies, approves, or defers the 
application subject to conditions.

Permit to Perform Work on State Highways. This permit must be obtained by the applicant to install the steam pipeline across the State highways. The issuance of a permit to perform work within a State Highway is contingent on the submission of and approval of the construction plans by the State Department of Transportation. The Department of Transportation will review and approve, approve with modification, or deny the permit request.

Construction Within County Government Right-of-Way. A conditional consent is issued by the County Department of Public Works prior to the application for a permit to excavate. Plans and specifications for steam pipeline crossings under County highways must be submitted to and reviewed by the department. There is no permit requirement except the conditional agreement and the excavation permit.

Permit for Excavation of County Highways. The transmission pipeline must cross county highways at several locations. Culverts are planned for these points and excavation of the roadway is required.

Plans and specifications are submitted and a permit is issued by the County Department of Public Works. During construction, the department inspects and accepts the work.

Authority to Construct and Permit to Operate. Chapter 43 of the State Department of Health regulations establishes a specific requirement for permits of all new sources of air pollution before construction and operation. Hence, permitting is required for the wellsite facilities which will include the wells and the $\mathrm{H}_{2} \mathrm{~S}$ conversion system. 
The application must show to the satisfaction of the department that:

- The new source is designed, built, and equipped in accordance with the best practicable control technology so as to reduce emissions to a minimum.

- The new source is designed and will be constructed to operate without causing a violation of applicable ambient air quality standards.

Bujlding, Electrical, and Plumbing Permits. Construction permits for building, electrical and plumbing must be issued for the wellsite facilities prior to construction. The basis of standards are the "Uniform Building Code," "National Electrical Code," and the Uniform Plumbing Code."

Building Plan Approval (Fire). The intent of these regulations is to provide minimum standards in regards to fire and life safety features for new and existing facilities based on the National Fire Protection Association codes. Plans and specifications are processed by the Fire Department.

Private Sewage Disposal System/Treatment Works Approval. The conventional means of sanitary waste disposal in the area is by means of a cesspool. In keeping with the normal practice, discharges of sanitary wastes at the well site will be to a cesspool. Percolation tests to determine specific capacity and permeability may be required by the Director to determine the type of permissible private sewage disposal system. Due to the porous nature of the ground at the wellsite area, however, a cesspool is not expected to pose difficulties. No private sewage disposal system can be constructed in an unsewered area unless approved by the Director of Health. Plans and specifications must be submitted to the Director of Health, and approved in 
writing. Inspection is required before operation of the private sewage disposal system.

Grubbing, Grading, Excavation, and Stockpiling Permit. All locations of the project must submit to this permit. The intent of this regulation is to provide standards to safeguard property, control erosion and sedimentation and to promote public welfare by regulating and controlling excavation, fills, grading, grubbing and stockpiling operations.

Plans and specifications are submitted to and receive approval of the Department of Public Works after review by the Bureau of Plans and Surveys.

Outdoor Lighting. This regulation controls the harmful effects of atmospheric light scattering. The purpose is to help preserve the unique qualities of mountain top areas for astronomical studies, which would be impeded by uncontrolled light illuminating the sky. Area lighting at the wellsite will be subject to this provision.

The developmental plans should adhere to good shielding and filtration practice. There is no special permit requirement other than $\mathrm{plan}$ and specifications approval. The Division of Traffic Safety and Control and the Bureau of Building Construction \& Inspection review and approve the plans and specifications submittals.

\subsubsection{Pipeline Rights of Way.}

Since State and County highways follow nearly a direct route from the East Rift Zone to Keaau, initial effort in establishing a pipeline corridor centered on easements within these highway rights-of-way. Encroachment into County highway rights-of-way appears to present no special problems with the exception of federal aid secondary county highways, which are 
regulated by the State Department of Transportation (DOT).

Correspondence with the State DOT, however, indicates that their policy is more restrictive than the County's. Longitudinal encroachment into the State highway's rights-of-way will be allowed only to privately owned, publicly owned or cooperatively owned utilities. Access of privately owned pipelines intended for exclusive private use is limited only to crossings.

To pursue the pipeline route within highway rights-of-way then left Puna Sugar with an option of being considered a private or cooperative utility, subject to the rules and regulations of the State Public Utilities Commission (PUC). The added restrictions that would be imposed on an agriculturally based operation make that alternative prohibitive to consider. Fortunately, other alternative routes are available in this particular study and the DOT policy is of little consequence.

The DOT policy, however, may act as a serious deterrent to other geothermal development programs. The economic utilization of geothermal resources requires large scale end users that need to locate plants on substantial parcels of land. It obviously is not practical to locate these facilities near the resource, which is in the volcanically active rift zone. But to prudently locate the end use in an area removed from the rift zone introduces the question of pipeline transmission corridors. It may be well, then, that the State and County address the possibility of establishing an energy corridor along highway rights-of-way or other alternative routes.

\subsubsection{Environmental Restrictions}

The project can accommodate the present environmental regulations. All 
pollution discharge standards and ambient air quality regulations can be met. However, with any substantial growth in geothermal utilization, there will likely be efforts to apply more stringent discharge standards. Warranted or unwarranted, more stringent environmental criteria reduces the economic feasibility of any project. A rational policy of evaluating the benefits of geothermal development and environmental quality must persist.

\subsection{TAX POLICY}

The 1978 Energy Act passed by Congress has to a large extent settled many unanswered questions relating to the economics of geothermal development. Among the major tax provisions included were an additional 10\% investment tax credit for energy related capital, a depletion allowance which stabilizes at 15\% after 1983, and expense allowances for intangible drilling costs. Together, the latter two expenses bring geothermal tax allowances more nearly equal to that previously enjoyed by the oil and gas industries.

While these tax provisions are certainly noteworthy and beneficial to the geothermal industry, a note of caution should be expressed. The full apparent gain cannot be realized from the tax benefits for those initially entering the geothermal industry. It is especially true for those that enter for only a single project. Provisions in the Energy Act reduce the apparent benefits by the mechanism of minimum tax on preference items and requirements for previous operating income in geothermal activities. Section 9 treats the provisions of the 1978 Energy Act in more detail.

\subsection{ELECTRIC RATE STRUCTURE}

Electric power distribution and sales are regulated by the State Public Utilities Commission which acts as a hearing board for all utility rate cases. In addition, the Public Utilities Division of the State Department 
of Regulatory Agencies exists and functions primarily as a consumer advocate. Together, these two agencies have established the working climate for electric utility operation in Hawaij.

By statutory decree, the operations of cane sugar facilities that sell excess power to the utilities are specifically exempt from the rules and regulations of the State Public Utilities Commission. The electric rate structure, however, does come within the purview of the Commission.

Puna Sugar Company has, since 1971, been providing electric power for sale to the public utility, HELCO. The terms of the agreement provide that Puna Sugar supply HELCO with power at predesignated export levels and as dispatched by HELCO for 48 continuous weeks per year. This export power varies from 4MW to 6MW depending on the time of day and the day of the week.

For this power commitment, HELCO currently pays Puna Sugar a fixed annual capacity charge of $\$ 18.50$ per maximum kilowatt supplied and a demand charge of 24.36 mills per kWh. The demand charge is annually adjusted in the month of July, based on an economic dispatch of all available generating units in the system, for the following twelve months, including non-HELCO units. The computer production simulation then determines the marginal fuel cost to HELCO. This incremental fuel cost per kWh is the newly adjusted demand charge that Puna Sugar receives for the succeeding 12 months.

The fee policy is viewed by the sugar factories as being very inequitable. Were it not for ancillary costs imposed by environmental pollution regulations, few sugar producers on the island would even consider selling power to utilities. The fee structure fails to consider the actual total marginal 
cost of producing electricity when a block of power is made available to HELCO, as is the case with the Puna Sugar supply. Besides the fuel oil equivalency, other marginal costs should also be included within the demand charge.

- $\quad$ Fixed Operating and Maintenance Costs. When a generating unit supplies a block of power, the marginal generating costs should consider all fixed 0 \& $M$ expenses associated with operating that unit. These include operator salaries, replacement parts, consumables, etc.

- Variable Operating and Maintenance Costs. There is an additional cost of generation associated with increased energy supply. As an example, more inplant power is consumed to generate $100,000,000 \mathrm{kWh}$ as opposed to $50,000,000 \mathrm{kWh}$ annually, although fixed costs are constant.

- Administrative and General Expenses. The $G \& A$ costs should be a legitimate cost item of generating electricity.

- Revenue Requirement for Cash Working Capital. There is a requirement for retaining working capital to operate a generating plant. This capital is used to purchase fuel and replacement parts, pay salaries, and to meet other operating expenses. The revenues that could otherwise be derived from this money should be reimbursable.

- Actual Fuel 0il Cost. Fuel oil costs should be based on the actual prevailing costs during the 12 month period, rather than the fuel oil price at the beginning of the period. The present rate structure does not compensate for interim price escalations. 
Even with the allowance for the actual marginal costs, the cost of generation will probably not reach HELCO's average busbar cost of $39 \mathrm{mills}$ per kWh. How this inequity will be viewed by the State regulatory agencies is unclear, but it is evident that the present rate structure is biased and restricts innovative alternative energy production growth.

\subsection{ELECTRIC POWER PRODUCTION AND EXPORT}

Besides the electric rate structure, other electrically related conflicts underlie the economic feasibility of this project. A detailed system review must resolve these problems at the appropriate time, and for this study, they can only be briefly addressed in the following subsections.

\subsubsection{Export Power and Energy Schedule}

With the modifications, the turbogenerator can be utilized to its full capacity of 18.75 MVA or $16.875 \mathrm{MW}$ at 0.9 power factor. Of this power, approximately $4.5 \mathrm{MW}$ are consumed within the plant, leaving a continuous base load of $12.32 \mathrm{MW}$ that can be exported to the utility. The key term here is "base load." The economic feasibility of the entire proposal is contingent on the Puna Sugar turbogenerator operating at constant export levels throughout the season. Without this feature, it is impossible for the existing unit to furnish enough revenue to even marginally compensate for the geothermal investment.

The present electric power contract between Puna Sugar and HELCO is a modified form of base loading, as a minimum power supply of 4 MW is always being exported. During the day, as the HELCO system demand increases, the export from Puna Sugar is raised to $6 \mathrm{MW}$. Table 3-1 relates this daily schedule of energy export. 
The operating relationship is obviously to HELCO's and ultimately the public's advantage. The Puna Sugar unit, and other island sugar factory generation systems, take up much of the peak daily loads of the utility system. It is doubly advantageous to HELCO because the purchase power rates are lower than the average HELCO bus bar costs. There should be some compensating incentive for producing this relatively stable and inexpensive power. In this study, the compensation is manifested as a base load operation.

There is general precedence for establishing geothermal systems as base load units. This position results from two primary reasons. Established geothermal power generation is relatively inexpensive as compared to other available sources of power in the area. Even more important, production from individual wells is difficult to attenuate. Geothermal wells are either fully producing or shut-in.

In the specific case of Puna Sugar, the power contract with HELCO is scheduled to terminate in 1991 . However, it is felt that a contract renegotiation for base load operation is in the best interest of all parties, should geothermal implementation be realized. The general mood of the public and local government is favorable to the principle of alternative energy utilization.

\subsubsection{Market Potential}

The most striking feature of the island electric energy economy is the great disparity between huge, apparently available alternate energy sources, and the limited demand for that energy. Five hundred megawatts for 100 years has been estimated for the size of the HGP-A geothermal 
reservoir, and this is only one of several high potential geothermal areas on the island. Vast areas of the island, especially near the peaks of Mauna Loa, Mauna Kea, and Hualalai, experience virtually cloudfree skies, and are exposed to intense solar radiation. Much of the windward section of the island is exposed to strong offshore tradewinds, and off Keahole Point in West Hawaii, the bathymetry is ideal for energy recovery using the principle of differential oceanic temperatures.

However, for all this potential, the fact remains that electrical end use on the island is small. In 1977, a total of 377 million kWh was sold through HELCO, as compared to 4,911 million kWh sold in the City and County of Honolulu. Peak HELCO system loads reflect the energy sales pattern, with about $80.5 \mathrm{MW}$ being consumed. Even more important to this project is the minimum load which is approximately $32 \mathrm{MW}$. With no economical method to transmit energy between islands during minimum load periods, a large baseload unit can significantly affect utility operations by forcing the utility to pick up more of the peaking function.

Accentuating the problem of minimum load is the fact that HELCO is committed to providing additional generating capacity before the end of 1983. Negotiations are currently progressing with Honokaa Sugar Company for providing a maximum of $12 \mathrm{MW}$ and a minimum of $5 \mathrm{MW}$ by 1981 , utilizing a bagass.e system. Should negotiations fail, and no alternative generating facility is available, a $25 \mathrm{MW}$ fossil fueled generating plant will be built for on-line service in 1983 . The latter action will probably effectively delay the Puna Sugar project until the late 1980's.

There are mitigating circumstances, however, that will probably allow inclusion of a geothermal base load unit even if the Honokaa Sugar 
facility goes on line. The electric consumption is increasing at about $5.5 \%$ yearly. By 1983, the first year of the proposed Puna Sugar project's operation, minimum load should be about $44 \mathrm{MW}$. The increase in the Puna Sugar export base load of $8 \mathrm{MW}$ is relatively small, less than the 12 MW increase in the utility system minimum demand. Nevertheless, careful analyses and negotiations must be conducted prior to any final decision. It will be interesting to note the viewpoints of the Public Utilities Commission and the Public Utilities Division, for their decisions will ultimately offer a direction for geothermal electric energy production in Hawai i. 


\section{REFERENCES}

11-1 Wong, Johnson, "Ownership of Resources," from Proceedings, Geothermal Seminar, Department of Research and Development, County of Hawaii, Hilo, Hawaii, October 18-19, 1977.

11-2 Bethea, Robert, "Institutional Relationships," from Proceedings, Geothermal Seminar, Department of Research and Development, County of Hawai i, Hilo, Hawaii, October $18-19,1977$.

11-3 "Judge Cuts Back Public's Shore Property," The Honolulu Advertiser, October 17, 1978.

11-4 Fuke, Sidney, "Land Use Regulations," from Proceedings, Geotherma 1 Seminar, Department of Research and Development, County of Hawai i, Hilo, Hawaii, October 18-19, 1977.

11-5 Lum, Danie1, Proceedings of the Symposium on Energy, Department of Research and Development, County of Hawai i, Hilo, Hawai i, May 18-19, 1977. 
Appendix $A$

PUNA SUGAR COMPANY BASELINE OVERALL MATERIAL BALANCE

The data and results of calculations for the baseline process material flows are presented in tabular form. Calculations are based on field cane and juice weights plus purity and sugar samples. The method employed is commonly referred to in the Hawaiian sugar industry as the inferential method. 
Appendix A

PUNA SUGAR COMPANY BASELINE OVERALL MATERIAL BALANCE

(Based On Reported Data From 1973 Thru 1977)

A. 1 CANE

A.1.1 Prepared cane per hour

A.1.2 Pol \% prepared cane

A.1.3 Tons pol in cane

A.1.4 Fiber \% prepared cane

A.1.5 Total tons fiber in prepared cane

A.1.6 Pol extracted

A.1.7 Extraction
$173.65 \mathrm{~T} / \mathrm{H}$

$9.1 \%$

$15.8022 \mathrm{~T} / \mathrm{H}$

$14.31 \%$

$24.8439 \mathrm{~T} / \mathrm{H}$

$15.2113 \mathrm{~T} / \mathrm{H}$

$96.2609 \%$

\section{A.2 BAGASSE}
A.2.1 Moisture \% bagasse
$48.8 \%$
A.2.2 Last expressed juice purity
$75.0 \%$
A.2.3 Ash \% bagasse (assumed)
$2.0 \%$
A.2.4 Bagasse pol \%
$1.18 \%$
A.2.5 Bagasse soluble solids \%
$1.5733 \%$
A.2.6 Bagasse fiber \%
$49.6267 \%$
A.2.7 Tons Bagasse
$50.0725 \mathrm{~T} / \mathrm{H}$
A.2.8 Tons pol in bagasse
$0.5909 \mathrm{~T} / \mathrm{H}$ 


\section{Appendix A (Contd)}

A. 3 MIXED JUICE

A.3.1 Dilution \% on prepared cane $32.0 \%$

A.3.2 Tons dilution water added $\quad 55.568 \mathrm{~T} / \mathrm{H}$

$\begin{array}{ll}\text { A.3.3 Tons mixed juice } & 179.1455 \mathrm{~T} / \mathrm{H}\end{array}$

A.3.4 Tons pol in mixed juice $15.2113 \mathrm{~T} / \mathrm{H}$

A.3.5 Pol \% mixed juice $\quad 8.491 \%$

A.3.6 Mixed jujce purity $88.2 \%$

A.3.7 Mixed juice solids $\quad 9.627 \%$

A.3.8 Tons soluble solids in mixed juice $\quad 17.2464 \mathrm{~T} / \mathrm{H}$

A. 4 CLARIFIED JUICE

$\begin{array}{ll}\text { A.4.1 Purity (use same as syrup) } & 88.2 \%\end{array}$

A.4.2 Juice solids $\quad 9.627 \%$

A.4.3 Tons Pol $15.2113 \mathrm{~T} / \mathrm{H}$

A.4.4 Tons solids in C.J. $\quad 17.2464 \mathrm{~T} / \mathrm{H}$

$\begin{array}{ll}\text { A.4.5 Tons clarified juice } & 179.1455 \mathrm{~T} / \mathrm{H}\end{array}$

A.5 SYRUP

A.5.1 Solids $63.0 \%$

A.5.2 Tons solids $17.2464 \mathrm{~T} / \mathrm{H}$

A.5.3 Tons pol $15.2113 \mathrm{~T} / \mathrm{H}$

A.5.4 Purity $88.2 \%$

A.5.5 Tons syrup $27.3752 \mathrm{~T} / \mathrm{H}$

$\begin{array}{ll}\text { A.5.6 Tons water evaporated } & 151.7703 \mathrm{~T} / \mathrm{H}\end{array}$ 
A. 6 MOLASSES
A.6.1 Solids
$83.5 \%$
A.6.2 Purity \%
$37.5 \%$
A.6.3 S-J-M recovery
$92.7369 \%$
A.6.4 Tons pol in molasses
$1.1048 \mathrm{~T} / \mathrm{H}$
A.6.5 Tons solids
$2.9461 \mathrm{~T} / \mathrm{H}$
A.6.6 Tons molasses
$3.5283 \mathrm{~T} / \mathrm{H}$

A.7 SUGAR
A.7.1 Pol
$98.3 \%$
A.7.2 Moisture
$0.35 \%$
A.7.3 $96^{\circ} \mathrm{DA}$ factor
1.0403
A.7.4 Pol Recovered in sugar
$14.1065 \mathrm{~T} / \mathrm{H}$
A.7.5 Recovery (boiling house)
$92.7369 \%$
A.7.6 Commercial sugar solids
$99.65 \%$
A.7.7 Commercial sugar purity
$98.6453 \%$
A.7.8 Tons solids in commercial sugar
$14.3002 \mathrm{~T} / \mathrm{H}$
A.7.9 Tons commercial sugar
$14.3504 \mathrm{~T} / \mathrm{H}$
A.7.10 Tons $96^{\circ}$ DA sugar
$14.9281 \mathrm{~T} / \mathrm{H}$
A.7.11 Total recovery
$89.2694 \%$ 
Appendix B

PIPELINE THERMAL LOSSES

A computer was utilized to calculate thermal losses in the 16 mile long pipeline transmission from the well site to the Puna Sugar process plant. Based on an average pipeline internal temperature of $385^{\circ} \mathrm{F}$ and a surface temperature of $90^{\circ} \mathrm{F}$, the following information was determined for calcium silicate insulation varying in thickness from 2 inches to 10 inches on pipeline diameters ranging from 8 inches to 24 inches. 
TABLE B-1

EXPECTED THERMAL LOSSES IN WELL SITE TO FACTORY STEAM PIPE

\begin{tabular}{|c|c|c|c|c|c|c|c|}
\hline $\begin{array}{l}\text { PIPE SIZE } \\
\text { (INCH) }\end{array}$ & $\begin{array}{l}\text { INSULATION } \\
\text { (INCH) }\end{array}$ & $\mathbf{K}$ & $\begin{array}{c}\mathrm{R} 1 \\
\text { (1 NCH) }\end{array}$ & $\begin{array}{c}\mathrm{R2} \\
\text { (INCH) } \\
\end{array}$ & $\begin{array}{c}Q \\
(B T U / S F T) \\
\end{array}$ & $\begin{array}{c}U \\
\text { (BTU/LFT) }\end{array}$ & $\begin{array}{l}\text { STEAM LOSS } \\
\text { LB/GR }\end{array}$ \\
\hline $\begin{array}{l}8 \\
8 \\
8 \\
8 \\
8 \\
8 \\
8 \\
8 \\
8\end{array}$ & $\begin{array}{r}2 \\
3 \\
4 \\
5 \\
6 \\
7 \\
8 \\
9 \\
10\end{array}$ & $\begin{array}{l}0.37 \\
0.37 \\
0.37 \\
0.37 \\
0.37 \\
0.37 \\
0.37 \\
0.37 \\
0.37\end{array}$ & $\begin{array}{l}4 \\
4 \\
4 \\
4 \\
4 \\
4 \\
4 \\
4 \\
4\end{array}$ & $\begin{array}{r}6 \\
7 \\
8 \\
9 \\
10 \\
11 \\
12 \\
13 \\
14\end{array}$ & $\begin{array}{r}44.87 \\
27.86 \\
19.68 \\
14.96 \\
11.91 \\
9.81 \\
8.28 \\
7.12 \\
6.22\end{array}$ & $\begin{array}{r}140.95 \\
102.13 \\
82.45 \\
70.48 \\
62.37 \\
56.50 \\
52.02 \\
48.49 \\
45.62\end{array}$ & $\begin{array}{r}14136 \\
10242 \\
8269 \\
7068 \\
6255 \\
5666 \\
5217 \\
4863 \\
4575\end{array}$ \\
\hline $\begin{array}{l}10 \\
10 \\
10 \\
10 \\
10 \\
10 \\
10 \\
10 \\
10\end{array}$ & $\begin{array}{r}2 \\
3 \\
4 \\
5 \\
6 \\
7 \\
8 \\
9 \\
10\end{array}$ & $\begin{array}{l}0.37 \\
0.37 \\
0.37 \\
0.37 \\
0.37 \\
0.37 \\
0.37 \\
0.37 \\
0.37\end{array}$ & $\begin{array}{l}5 \\
5 \\
5 \\
5 \\
5 \\
5 \\
5 \\
5 \\
5\end{array}$ & $\begin{array}{r}7 \\
8 \\
9 \\
10 \\
11 \\
12 \\
13 \\
14 \\
15\end{array}$ & $\begin{array}{r}46.34 \\
29.03 \\
20.63 \\
15.75 \\
12.58 \\
10.39 \\
8.79 \\
7.57 \\
6.62\end{array}$ & $\begin{array}{r}169.85 \\
121.60 \\
97.23 \\
82.45 \\
72.48 \\
65.28 \\
59.81 \\
55.51 \\
52.02\end{array}$ & $\begin{array}{r}17034 \\
12195 \\
9751 \\
8269 \\
7269 \\
6547 \\
5998 \\
5567 \\
5217\end{array}$ \\
\hline $\begin{array}{l}12 \\
12 \\
12 \\
12 \\
12 \\
12 \\
12 \\
12 \\
12\end{array}$ & $\begin{array}{r}2 \\
3 \\
4 \\
5 \\
6 \\
7 \\
8 \\
9 \\
10\end{array}$ & $\begin{array}{l}0.37 \\
0.37 \\
0.37 \\
0.37 \\
0.37 \\
0.37 \\
0.37 \\
0.37 \\
0.37\end{array}$ & $\begin{array}{l}6 \\
6 \\
6 \\
6 \\
6 \\
6 \\
6 \\
6 \\
6\end{array}$ & $\begin{array}{r}8 \\
9 \\
10 \\
11 \\
12 \\
13 \\
14 \\
15 \\
16\end{array}$ & $\begin{array}{r}47.43 \\
29.91 \\
21.37 \\
16.37 \\
13.12 \\
10.86 \\
9.20 \\
7.94 \\
6.96\end{array}$ & $\begin{array}{r}198.66 \\
140.95 \\
111.88 \\
94.29 \\
82.45 \\
73.92 \\
67.45 \\
62.37 \\
58.27\end{array}$ & $\begin{array}{r}19923 \\
14136 \\
11220 \\
9456 \\
8269 \\
7413 \\
6764 \\
6255 \\
5844\end{array}$ \\
\hline $\begin{array}{l}14 \\
14 \\
14 \\
14 \\
14 \\
14 \\
14 \\
14 \\
14\end{array}$ & $\begin{array}{r}2 \\
3 \\
4 \\
5 \\
6 \\
7 \\
8 \\
9 \\
10\end{array}$ & $\begin{array}{l}0.37 \\
0.37 \\
0.37 \\
0.37 \\
0.37 \\
0.37 \\
0.37 \\
0.37 \\
0.37\end{array}$ & $\begin{array}{l}7 \\
7 \\
7 \\
7 \\
7 \\
7 \\
7 \\
7 \\
7\end{array}$ & $\begin{array}{l}9 \\
10 \\
11 \\
12 \\
13 \\
14 \\
15 \\
16 \\
17\end{array}$ & $\begin{array}{r}48.26 \\
30.60 \\
21.95 \\
16.88 \\
13.56 \\
11.25 \\
9.55 \\
8.25 \\
7.24\end{array}$ & $\begin{array}{r}227.41 \\
160.23 \\
126.44 \\
106.03 \\
92.32 \\
82.45 \\
74.99 \\
69.13 \\
64.41\end{array}$ & $\begin{array}{r}22806 \\
16069 \\
12681 \\
10634 \\
9259 \\
8269 \\
7520 \\
6933 \\
6459\end{array}$ \\
\hline
\end{tabular}


TABLE B-1 (contd)

EXPECTED THERMAL LOSSES IN WELL SITE TO FACTORY STEAM PIPE

\begin{tabular}{|c|c|c|c|c|c|c|c|}
\hline $\begin{array}{l}\text { PIPE SIZE } \\
\text { (I NCH) }\end{array}$ & $\begin{array}{l}\text { INSULATION } \\
\text { (INCH) }\end{array}$ & $\mathbf{K}$ & $\stackrel{\mathrm{R} 1}{\text { (INCH) }}$ & $\begin{array}{c}\mathrm{R2} \\
\text { (INCH) }\end{array}$ & $\begin{array}{c}Q \\
\text { (BTU/SFT) }\end{array}$ & $\frac{U}{(B T U / L F T)}$ & $\underset{\text { LTEAM L LOSS }}{\operatorname{STEAR}}$ \\
\hline $\begin{array}{l}16 \\
16 \\
16 \\
16 \\
16 \\
16 \\
16 \\
16 \\
16\end{array}$ & $\begin{array}{r}2 \\
3 \\
4 \\
5 \\
6 \\
7 \\
8 \\
9 \\
10\end{array}$ & $\begin{array}{l}0.37 \\
0.37 \\
0.37 \\
0.37 \\
0.37 \\
0.37 \\
0.37 \\
0.37 \\
0.37\end{array}$ & $\begin{array}{l}8 \\
8 \\
8 \\
8 \\
8 \\
8 \\
8 \\
8 \\
8\end{array}$ & $\begin{array}{l}10 \\
11 \\
12 \\
13 \\
14 \\
15 \\
16 \\
17 \\
18\end{array}$ & $\begin{array}{r}48.91 \\
31.16 \\
22.43 \\
17.29 \\
13.93 \\
11.58 \\
9.84 \\
8.52 \\
7.48\end{array}$ & $\begin{array}{r}256.12 \\
179.46 \\
140.95 \\
117.71 \\
102.13 \\
90.92 \\
82.45 \\
75.82 \\
70.48\end{array}$ & $\begin{array}{r}25685 \\
17998 \\
14136 \\
11805 \\
10242 \\
9118 \\
8269 \\
7604 \\
7068\end{array}$ \\
\hline $\begin{array}{l}18 \\
18 \\
18 \\
18 \\
18 \\
18 \\
18 \\
18 \\
18\end{array}$ & $\begin{array}{r}2 \\
3 \\
4 \\
5 \\
6 \\
7 \\
8 \\
9 \\
10\end{array}$ & $\begin{array}{l}0.37 \\
0.37 \\
0.37 \\
0.37 \\
0.37 \\
0.37 \\
0.37 \\
0.37 \\
0.37\end{array}$ & $\begin{array}{l}9 \\
9 \\
9 \\
9 \\
9 \\
9 \\
9 \\
9 \\
9\end{array}$ & $\begin{array}{l}11 \\
12 \\
13 \\
14 \\
15 \\
16 \\
17 \\
18 \\
19\end{array}$ & $\begin{array}{r}49.45 \\
31.62 \\
22.83 \\
17.65 \\
14.24 \\
11.86 \\
10.10 \\
8.75 \\
7.69\end{array}$ & $\begin{array}{r}284.80 \\
198.66 \\
155.42 \\
129.35 \\
111.88 \\
99.33 \\
89.86 \\
82.45 \\
76.49\end{array}$ & $\begin{array}{r}28562 \\
19923 \\
15586 \\
12972 \\
11220 \\
9961 \\
9012 \\
8269 \\
7670\end{array}$ \\
\hline $\begin{array}{l}20 \\
20 \\
20 \\
20 \\
20 \\
20 \\
20 \\
20 \\
20\end{array}$ & $\begin{array}{r}2 \\
3 \\
4 \\
5 \\
6 \\
7 \\
8 \\
9 \\
10\end{array}$ & $\begin{array}{l}0.37 \\
0.37 \\
0.37 \\
0.37 \\
0.37 \\
0.37 \\
0.37 \\
0.37 \\
0.37\end{array}$ & $\begin{array}{l}10 \\
10 \\
10 \\
10 \\
10 \\
10 \\
10 \\
10 \\
10\end{array}$ & $\begin{array}{l}12 \\
13 \\
14 \\
15 \\
16 \\
17 \\
18 \\
19 \\
20\end{array}$ & $\begin{array}{r}49.89 \\
32.00 \\
23.17 \\
17.95 \\
14.51 \\
12.10 \\
10.32 \\
8.95 \\
7.87\end{array}$ & $\begin{array}{r}313.46 \\
217.83 \\
169.85 \\
140.95 \\
121.60 \\
107.70 \\
97.23 \\
89.04 \\
82.45\end{array}$ & $\begin{array}{r}31436 \\
21846 \\
17034 \\
14136 \\
12195 \\
10801 \\
9751 \\
8930 \\
8269\end{array}$ \\
\hline $\begin{array}{l}24 \\
24 \\
24 \\
24 \\
24 \\
24 \\
24 \\
24 \\
24\end{array}$ & $\begin{array}{r}2 \\
3 \\
4 \\
5 \\
-6 \\
7 \\
8 \\
9 \\
10\end{array}$ & $\begin{array}{l}0.37 \\
0.37 \\
0.37 \\
0.37 \\
0.37 \\
0.37 \\
0.37 \\
0.37 \\
0.37\end{array}$ & $\begin{array}{l}12 \\
12 \\
12 \\
12 \\
12 \\
12 \\
12 \\
12 \\
12\end{array}$ & $\begin{array}{l}14 \\
15 \\
16 \\
17 \\
18 \\
19 \\
20 \\
21 \\
22\end{array}$ & $\begin{array}{r}50.58 \\
32.61 \\
23.71 \\
18.43 \\
14.96 \\
12.50 \\
10.68 \\
9.29 \\
8.19\end{array}$ & $\begin{array}{l}370.75 \\
256.12 \\
198.66 \\
164.08 \\
140.95 \\
124.37 \\
111.88 \\
102.13 \\
94.29\end{array}$ & $\begin{array}{r}37181 \\
25685 \\
19923 \\
16455 \\
14136 \\
12472 \\
11220 \\
10242 \\
9456\end{array}$ \\
\hline
\end{tabular}

